Florida International University

FIU Digital Commons

$11-8-2019$

\title{
Reggaeir@ Sou Eu: Race, Nation and the Politics of Identity in Roots Reggae Culture in Sao Luis do Maranhao, Brazil
}

Gloria Angebelle Yawson

Florida International University, gyaws001@fiu.edu

Follow this and additional works at: https://digitalcommons.fiu.edu/etd

Part of the Other Anthropology Commons, and the Social and Cultural Anthropology Commons

\section{Recommended Citation}

Yawson, Gloria Angebelle, "Reggaeir@ Sou Eu: Race, Nation and the Politics of Identity in Roots Reggae Culture in Sao Luis do Maranhao, Brazil" (2019). FIU Electronic Theses and Dissertations. 4330.

https://digitalcommons.fiu.edu/etd/4330

This work is brought to you for free and open access by the University Graduate School at FIU Digital Commons. It has been accepted for inclusion in FIU Electronic Theses and Dissertations by an authorized administrator of FIU Digital Commons. For more information, please contact dcc@fiu.edu. 


\title{
FLORIDA INTERNATIONAL UNIVERSITY
}

Miami, Florida

\section{REGGAEIR@ SOU EU: RACE, NATION AND THE POLITICS OF IDENTITY IN ROOTS REGGAE CULTURE IN SÃO LUIS DO MARANHÃO, BRAZIL}

\author{
A dissertation submitted in partial fulfillment of the \\ requirements for the degree of \\ DOCTOR OF PHILOSOPHY \\ in \\ GLOBAL AND SOCIOCULTURAL STUDIES \\ by \\ Gloria Angebelle Yawson
}


To: John F. Stack Jr.

Steven J. Green School of International and Public Affairs

This dissertation, written by Gloria Angebelle Yawson, and entitled Reggaeir@ Sou Eu: Race, Nation and the Politics of Identity in Roots Reggae Culture in São Luis do Maranhão, Brazil, having been approved in respect to style and intellectual content, is referred to you for judgment.

We have read this dissertation and recommend that it be approved.

Andrea Queeley

Victor Uribe-Uran

Benjamin Smith

Vrushali Patil, Major Professor

Date of Defense: November $8^{\text {th }} 2019$

The dissertation of Gloria Angebelle Yawson is approved.

John F. Stack Jr.

Steven J. Green School of International and Public Affairs

Dean Andrés G. Gil

University Graduate School 
Florida International University, 2019

\section{DEDICATION}

I am an intellectual being but above all, I am spiritual being in a body with a distinct purpose as assigned by my creator, Yahweh. This dissertation has been one of my assignments on the path to my sanctification. I dedicate my dissertation to my Lord and Savior Jesus Christ, whose favor has carried me throughout this process. I owe all of my eternal gratitude to Him. I also dedicate this work to my spouse, Gabriel Oyeleke, and to my parents, siblings and friends for their continuous prayers and support. 


\section{ACKNOWLEDGMENTS}

I would like to thank the members of my committee for their support and guidance throughout the dissertation research and writing process. I would like to thank Dr. Patricia Price for her guidance and mentorship during the earlier portion of doctoral training. I owe my deepest gratitude to Dr. Vrushali Patil for her tremendous support and vote of confidence in helping me to complete my dissertation at a dire time. I would also like to thank my parents, Franklin and Rahab Yawson, my spouse, Gabriel Oyeleke, my siblings, Emmanuel and Deborah Yawson, and cousins, Rebecca Adjei, Emmanuella Adjei for their prayers, support and continuous encouragement. I would like to thank my Aunt Esther Adjei for always being a great support system. I would like to extend my tremendous gratitude to my Brazilian family and my Maranhese support system, Rodvania Macedo, Fernando Telles, Rosiane Cardoso, Rodrigo Reduzino, and Carlos Silva. I owe an exceptional gratitude to Ribamar Nascimento for his guidance and emotional support throughout my fieldwork. I would not have been able to get through this portion of my work without him, and for that I am incredibly thankful. I thank my friends, Felipe Tendick-Matesanz, Eleanor Annan, Lauren Au, Alessandra Rosa, Audi Flemmings, and Gaille Gregoire, who have been of incredible help emotionally in one shape or form throughout my writing process. I would also like to thank my Aunt Marilyn Bailey, who prayed and encouraged me to trust in God's timing and purpose for my work. I would like to thank the people of São Luis do Maranhão and all 
reggaeir@s for dancing with me through this research. Above all else, I thank God the Father, Son and Holy Spirit for empowering me to push to the finish line.

The Tinker Fellowship, Foreign language and Area Studies (FLAS) Fellowship and the Boren Fellowship granted the funding for this research. However, any opinions expressed in this dissertation are those of the author and do not represent the views of any of the funding agencies or institutions. 
ABSTRACT OF THE DISSERTATION

\title{
REGGAEIR@SOU EU: RACE, NATION AND THE POLITICS OF IDENTITY IN ROOTS REGGAE CULTURE IN SÃO LUIS DO MARANHÃO, BRAZIL
}

\author{
FLC \\ =56712 $($ 'DKBFB55B $(/ 2 \mathrm{MA6D}($ \\ !567182(\%DCB7D2C16D25(,D1RB7A1CL4(NOPQC \\ $012314(! 567182($ \\ <76HBAA67(-7EAI251(<2C154(02S67(<76HBAA67C
}

This dissertation examines the performative space of roots reggae music and dance performancescape in São Luis do Maranhão, Brazil. It examines the ways in which Caribbean sounds are employed by Afro-Maranhese to create performative spaces that contest representations of blackness in Brazil. In this examination, I address how AfroMaranheses engage in the process of transformation by appropriating Caribbean Sounds in the performative spaces of blackness. The dissertation also examines the ways in which these performative spaces, as spaces of struggle are objects of legal forms of surveillance, discipline and punishments that are targeted by the policia militar (military police) because they critically challenge the state's representations of blackness.

I make two pronounced contentions to support all of my arguments in this study. Firstly, I posit that musical and dance practices are essential to the understanding of the production of Afro-Brasilidade Space - what I have termed as the dialogic performative space that represents the series of repeated responsive performances that Afro-Brazilians engage in, in the challenge of the state's simultaneous celebration of black culture and routine violence against black bodies. Borrowing Brah's (1996) construct of diaspora 
space and Dirlik's (1996) notion of "ancestralidade" (ancestrality), I define AfroBrasilidade Space as the articulated and expressive space of contestation where representations of blackness are challenged. It is also the conceptual space that allows Afro-Brazilians to produce their versions of Afrodiasporic subjectivities, which I define as the ways in which Afro-Brazilians, like other people of African descent in the African diaspora engage in similar enunciations of contestation to combat their own experiences of racialized subjectivity. Additionally, I couple Afro-Brasilidade Space with the term reggaeir@ bodies to show how enunciations of musical practices interconnect with the discursive construction of racialized bodies in Brazil under affirmative action policies. I employ this analytical framework to highlight the performative space of roots reggae music and culture in the critical practice of blackness, and how these are inscribed in and contest the pedagogical discourse of nation and citizenship organized around racial democracy as part of the broader Afrodiasporic performance-scape.

Secondly, I argue that the study of an Afrodiasporic musical practices such as reggaeir@ismo requires an examining of different forms that agency can take, particularly agency in response to state violence against the black body. I argue that the embodied practices of reggaeir@ismo in the performative of roots reggae are counterdiscursive and counter-hegemonic, and this explains why these spaces are heavily policed. I fundamentally focus my arguments on the assertions that Brazilian affirmative action, as a documentary practice is not fundamentally corrective. I also argue that racial democracy as a discourse of hybridity persist to obscure very real forms of racial oppression and inequalities even with the institution of affirmation action policies. AfroBrazilians have been discursively included in the space of citizenship through the denial of their blackness. 
Introduction: Race, Nation, and the Politics of Identity .......................................................... 1

Structure of Dissertation:

Chapter 1, Literature Review, Analytics, Research Design and Methodology ............ 6

II. Chapter 1, Literature Review, Analytics, Research Design and Methodology ..............10

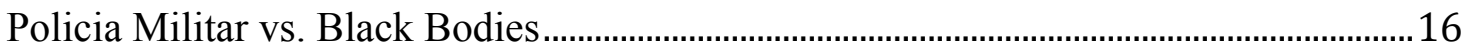

Defining Difference Under Statist Discourse ................................................................. 18

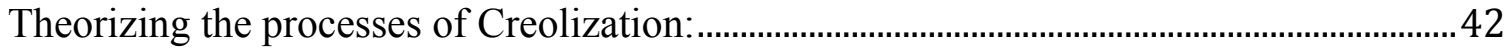

Part IV: Theoretical Underpinnings of Afro-Brasilidade Space and the African

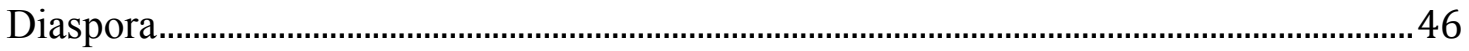

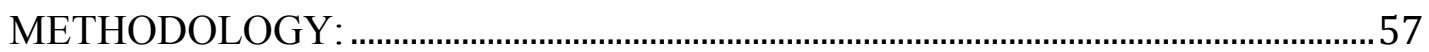

III. Chapter 2, “A Viagem”: Historicizing Roots Reggae and the Reggaeir@ Space........73

Contextualizing the Reggaeir@ Space, the Island City of São Luis do Maranhão........73

Jamaica Brasileira me Encanta: My first encounters with São Luis do Maranhão and its Roots Reggae music Scene

Historicizing the Creation of the Reggaeir@Performative Spaces: Innovating with the

Radiola/Sound System .............................................................................................. 101

Articulations of Black Dance Practices in Local Spaces: .................................................. 104

Transitioning from "merengue” and "International” Music to Roots Reggae:....... 107

IV. Chapter 3: Democraçia Racial: Navigating Statist Discourse and the

Criminalization of Reggaeir@Space and Bodies.

Policing the Periferias: A balance between in Laws and Policies versus land Rights and Land Control.

Policing of Particular Reggaeir@ Dance Spaces in the Media: The case of Club

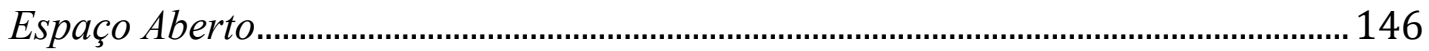

V. Chapter 4, Reggaeir@ Culture as Counter Discourse.................................................... 162

The Creation and Production of Afro-Brasilidade Space ................................................. 167

Contextualizing and Conceptualizing Afro-Brasilidade Space .................................... 170

The Reggaeir@Performance Space: Mixing, Black Identity and Afro-Brasilidade Space

Agarrar, Agarrado, Agarradinho: The dialogic, Mixing and Diaspora ....................... 201 
Reggaeir@ Bodies in Motion: “Caribbeanizing” Afro-Maranhese Identity in the

Reggaeir@ Performative Space....................................................................................205

VI: Chapter 5, Localized Situations and Rhythmanalysis ....................................................212

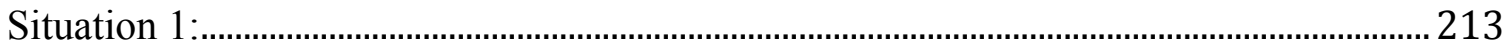

O Reggae é Agarradinho: The Reggaeir@ Space, Dance, Self-Fashioning and Leisure

Chama Maré, Bar Nelson Centro: The Reggaeir@ Space Through the Lens of Tourism 216

Celso Cliff and Agarradhinho: Style, Self-Fashioning and Leisure ..........................227

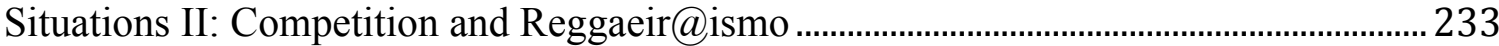

Vinyl Sets and Antiquity: Roots and Routes in the Art of Disc Jockeying ...................233

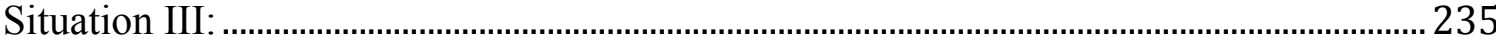

Espaço Aberto and San Francisco: Power, Politics and the Reggaeir@ Movement..235

Reggae is our identity: Reggaeir@ Sou Eu/I am Reggaeir@......................................236

VII: Conclusion, Where the Work Starts ..........................................................................2 240

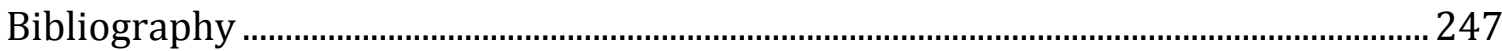

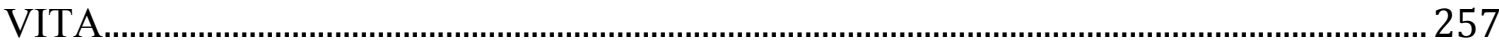




\section{Introduction: Race, Nation, and the Politics of Identity}

The fragile psychological, emotional, and cultural correspondences which connect diaspora populations in spite of their manifest differences are often apprehended only fleetingly and in ways that persistently confound the protocols of academic orthodoxy (Gilroy 1993:81).

This dissertation examines the performative space of roots reggae music and dance performance-scape in São Luis do Maranhão, Brazil. It examines the ways in which Caribbean sounds and rhythms are employed by Afro-Maranhese to create performative spaces that contest representations of blackness in Brazil. In this examination, I address how Afro-Maranheses engage in the process of transformation by appropriating Caribbean Sounds in the performative spaces of blackness. The dissertation also examines the ways in which these performative spaces, as spaces of struggle are objects of legal forms of surveillance, discipline and punishments that are targeted by the policia militar (military police) because they critically challenge the state's representations of blackness.

I make two pronounced contentions to support all of my arguments in this study. Firstly, I posit that musical and dance practices are essential to the understanding of the production of Afro-Brasilidade Space — what I have termed as the dialogic performative space that represents the series of repeated responsive performances that Afro-Brazilians engage in, in the challenge of the state's simultaneous celebration of black culture and routine violence against black bodies. Borrowing Brah's (1996) construct of diaspora space and Dirlik's (1996) notion of "ancestralidade" (ancestrality), I define AfroBrasilidade Space as the articulated and expressive space of contestation where 
representations of blackness are challenged. It is also the conceptual space that allows Afro-Brazilians to produce their versions of Afro-diasporic subjectivities, which I define as the ways in which Afro-Brazilians, like other people of African descent in the African diaspora engage in similar enunciations of contestation to combat their own experiences of racialized subjectivity. Additionally, I couple Afro-Brasilidade Space with the term reggaeir@ bodies to show how enunciations of musical practices interconnect with the discursive construction of racialized bodies in Brazil under affirmative action policies. I employ this analytical framework to highlight the performative space of roots reggae music and culture in the critical practice of blackness, and how these are inscribed in and contest the pedagogical discourse of nation and citizenship organized around racial democracy as part of the broader Afro-diasporic performance-scape.

Several scholars working on black performance work in the Latin American and the Caribbean region; particularly Peter Wade (1998, 2000) and Yvonne Daniel (2011) have underscored this point. However, I suggest that a distinct examination of practices of what I term as reggaeir@ismo-the critical embodied practices of roots reggae music and dance culture in São Luis, would reveal the practice as divergent from all others in the region. In the past few decades, regional scholarship on general state-sanctioned indigenous rights reforms and political correction of racial inequalities the Latin American and the Caribbean region have all been buried under the label of "multiculturalism". Consequently, in the scholarship of multiculturalism as a broader term with respect to the politics of recognition and redistribution, the distinction between what Taylor (1994) as the "politics of recognition", which is the political struggles for cultural recognition as opposed to material redistribution is often neglected (see also 
Kymlicka 2010b). In this work, I argue that Brazilian affirmative action policies differs from the broader general multiculturalist approach in the region because accounts of multiculturalism places too much emphasis on the group of study as the object of rights, and so such scholarship excludes inherent issues of racial inequality and disparity that are embedded in the pluralist discourses of state-sanctioned correctional policies themselves (Fraser 2003, Benhabib 2002). I argue that affirmative action policies discursively deviate from other multiculturalist policies of recognition and distribution, which in turn interacts with Afro-Brazilian music and dance practices differently than it does in other African diaspora spaces in the region. This requires a different reading of AfroBrasilidade Space as part of the broader performance-scape of the African Diaspora. In the process, I am using this work to implore other Brazilinist scholars to think about Afro-Brazilians as participation in the space of the African Diaspora differently; especially where enunciations of music and dance practices are engaged as cultural practices of recognition. This analysis benefits African Diaspora Studies as well as Brazilian Cultural Studies and Latin America Studies in way that considers Brazil's reformative racial policies beyond the frame of multiculturalist correctives.

Secondly, I argue that the study of an Afrodiasporic musical practices such as reggaeir@ismo requires an examining of different forms that agency can take, particularly agency in response to state violence against the black body. I argue that the embodied practices of reggaeir@ismo in the performative of roots reggae are counterdiscursive and counter-hegemonic, and this explains why these spaces are heavily policed. I fundamentally focus my arguments on the assertions that Brazilian affirmative action, as a documentary practice is not fundamentally corrective. I also argue that racial 
democracy as a discourse of hybridity persist to obscure very real forms of racial oppression and inequalities even with the institution of affirmation action policies. AfroBrazilians have been discursively included in the space of citizenship through the denial of their blackness. At the same time and on necessary racial grounds, they have also been differentially and structurally incorporated into social and political economies in Brazil (Osório 2010). Consequently this symbolic incorporation of Afro-Brazilians into its national fabric economically, has increased the access to upward mobility for many AfroBrazilians, especially in the creation of black middle class population that was nonexistent in prior eras of democratization of the state (Soares, Ribas, and Osório 2010). In this new era of racial politics in Brazil, the result of the Brazilian's state's simultaneous inclusion of blacks in its national citizenship while it denies their blackness, manifest in the lived quotidian realities of many Afro-Brazilians over time as it poses contradictions that are inherent in the persistence of the hybridized discourse of racial democracy (Telles 2004).

Affirmative action has become a form of reactive crisis management tool that is necessitated by these contradictions. In its application, affirmative action employs the trope of equal rights that does not translate into its putative aims to correct the racial order inherent Brazil's longstanding discourse of racial democracy. As such, the persistent discourse of racial democracy alongside the institution of affirmative action policies have become instrumentalities of the repressive, oppressive Brazilian state that are employed to justify and normalize racial violence. Using the reggaeir@ performative space as a lens, I examine how affirmative action as a statist discursive tool attempts to render invisible the contradictions between the lived realities of punishing and 
disciplining reggaeir@s through violent policing of their performative spaces and its promises of equal rights for Afro-Brazilians in its new racial politics.

In this analysis, I highlight the need to not assume that there is an automatic connection between Afrodiasporic musical practices and their contestation to western hegemony (Monson 2000). Instead, I use this dissertation to show that Afrodiasporic musical practices serve as sites of resistance as well as sites of dialogic cultural politics as opposition, where products of liberation are not certain. I argue that these sites of practices of liberation occur within the context of power (Foucault cited in Rabinow 1997). As echoed by Mahmood (2001), I do not use the term liberation to connote western ideologies of freedom but instead to show that "the desire for freedom and liberation is a historically situated desire, that cannot be assumed but must be considered in relation to other desires, aspirations and capacities that are linked to a culturally and historically located subject" (Mahmood 2001: 223). As such, in this work I analogize liberation to be complicatedly interconnected to specific situated histories and discursive ideologies that create the dialogues and instances for resistance, agency, as well as the lack thereof of action. Practices of resistance and liberation in addition to inaction or coproduction of state documentary practices as evidenced in Afro-Brasilidade Space shows the dialogic relationship between statist discourse and Afro-Brazilian musical practices that informs Brazil's cultural politics. Accordingly, reggaeir@ismo is political and it should be understood from the perspective of racial and cultural politics. This analysis also benefits the scholarship of ethnomusicology and Cultural Studies in thinking about the politics of music differently. 


\section{Structure of Dissertation:}

\section{Chapter 1, Literature Review, Analytics, Research Design and Methodology}

In chapter one, I discuss the literature that informs this project. The goals of this chapter are: firstly to familiarize the reader with the scholarship of hybridity in Postcolonial Studies and its drawbacks; and secondly to argue for the reconceptualization of simplistic notions of syncretism and hybridity in the study of musical practices. I focus on the discursive inclusion and exclusion of Afro-Brazilian in the space of citizenship under the institution of affirmative action policies. I argue that affirmative action policies mainly manage the realities of racial disparities by attempting to obscure the contradictions of the discourse of racial democracy while it simultaneously maintains the racial hierarchical order imposed by the hybridity discourse. I argue that inherent in the statist discourse of racial democracy and hybridity are the contradictions of racial inequalities that are manifest in the violent policing of black performative spaces. I also argue that affirmative action attempts to reactively manage the contradictions by obscuring the crisis of violence against black bodies with social reforms that thwart the advances of equal rights for Afro-Brazilians. I use these arguments to suggest that the studies of these contradictions are best accessed in the localized processes of hybridity. Using the performative spaces of reggaeir@s as a lens I examine the discourse of belonging and citizenship in Brazil. 


\section{Chapter 2, "A Viagem": Historicizing Roots Reggae and the Reggaeir@ Space}

This chapter, unlike the others in this dissertation, is heavily historical and not theoretical in its accounts. I trace the historiographies of the city of São Luis and the various socioeconomic, sociopolitical and sociocultural factors that have influenced roots reggae music culture in the city. Through these historiographies, I show the genealogy of the performance-scape of roots reggae in São Luis that were developed from the intricate mixtures of Caribbean sounds, rhythms and sensibilities. I give accounts of how through maritime trade, Caribbean music forms and practices such as boleros, cumbia, cadence, merengue, calypso, guarachá, and compas became mixed with other local musical practices in innovated cultural spaces that eventually produced the reggaeir@ performance spaces. I also historicize how the 1960s military regime's promotion of transnational commercial music distribution through local businesses following the shutdown of informal maritime trade to the Caribbean impacted these performance spaces. The chapter also demonstrates how the interconnections between the access to AM Radio, the onset of the Brazilian Black Social Movement and the development of the lover's rocksteady and roots style introduced by the Jamaican artist, Jimmy Cliff in Brazil informed the reggaeir@ performance-scape. Finally, I also trace the importance of the contribution of the sound system industry and subversive dance spaces around São Luis produced black cultural spaces and informal music industry that extended beyond reggaeir@culture.

\section{Chapter 3, "Democraçia Racial”: Navigating Statist Discourse}

I focus on Statist discursive formation, its documentary practices and their instrument effects of disciplining, surveillance, violence and punishment. I show how 
racial democracy and affirmative action and hybridity are instrumentalities of an oppressive state that are used to justify and normalize racial violence. In order to demonstrate this both generally and in the ways that manifest in documentary practices and their effect, I go through how these instrumentalities are translated into practice and their effects. I connect these discussions with my discussions of practices of surveillance and violence through ethnographic and archival data that I have collected in the places that agarradinho occurs in succeeding chapters. I also connect these discussions with my discussions of forms of self-representation and meaning that is produced within the performance-scapes. Finally, I suggest that affirmative action policies serves as instrumentalities of oppression through codes of silence about the realities of racism and police brutality.

\section{Chapter 4, Roots Reggae as Counter Discourse}

I focus on an analysis of roots reggae music and dance as counter discourse and its relationship to the performative space of Afro-Maranheses and how it is distinguished from Afro-Brasilidade Space and its influence on ABS (Since ABS is a product of Statist Discourse). Here, I argue that agarradinho is a form of counter-discourse that challenges the statist discourse of racial democracy, affirmative action and hybridity. I suggest that the entire performance space organized around music and dance, including the cultural space organized around reggaeir@ismo is counter discursive. I show how it is manifested beyond the actual performance, suggesting that Afro-Maranhese identity is organized through and within the performative space of roots reggae music and dance. I argue how this is dialogic, how it influences and also different from Afro-Brasilidade space. I also make the assertion that the performance space is diasporic space by I detailing the 
elements of that diasporic space. Finally, I show this in the formative elements that constitute the performative space of roots reggae music and dance performance-scape. I portray how this different from Creole, mestizo and Brazilian forms of identities and how that poses a challenge to the state, such that it demands surveillance, violence and disciplinary practices deployed by the state.

\section{Chapter 5, Performance Ethnography and RhythmAnalysis}

In this chapter, I build on my analysis of the "rhizomatic" experiences of reggaeir@s from the previous chapter and how they have been shaped by the historiographies of São Luis do Maranhão through an ethnographic study of reggaeir@ismo, and how embodied music and dance performance shape spaces around the city. Here, I provide localized performative specificities and situated understandings of the processes that shape reggaeir@ performance identity, musical and dance practices. Specifically, I examine reggae and dance scene in clubs, open enclosed radiola spaces, concert and organized meeting to explore the embodiment of reggaeir@ismo.

\section{Conclusion, Where the Work Starts}

Finally, to conclude the project write up I summarize all chapters, and discuss practical, political as well as theoretical implications of the dissertation. I also address the pitfalls of the theoretical categories and methodology I employed in this project. 


\section{Chapter 1, Literature Review, Analytics, Research Design and Methodology}

In liberal multicultural discourse cultural hybridity has long offered a way of advancing culturalist notions of difference as inclusion or nonconflictual diversity; it functions there as an assimilationist discourse at a time when "separate" ethnic identities and inequalities threaten to become unmanageable. But far from resolving the crisis of multicultural societies, particular hybrid identities have been intimately connected with modes of both domination and resistance. In contemporary corporate discourse, the cultural hybridity symbolized by the "global village" provides an enabling discourse for the aggressive economic expansion of capital, the terms and terminology of which are increasingly marking not just the discourse of Economics, Business, and Communication in the academy, but also the discourse of the Humanities and Cultural Theoryarguably compromising their potential as a "critical discourse." My point is not that the long and often unsavory history of the idea of hybridity prohibits its appropriation by other agendas but that it should alert us to the precariousness of such appropriations... the political economy of cultural hybridity entails both progressive and conservative filiations and alliance. It is therefore toward not only the inclusions but also the exclusions of these discourses that I direct my attention." (Puri 2004, 4-5)

I commence this chapter with a quote from Shalini Puri to foreground some of the various central assertions that I pinpoint in this chapter. The sociopolitical mobilizations behind the use of hybrid terms such as mestizo, mulato, creole etc. has forced many postcolonial scholars to emphasize the need to connect notions of hybridity to a politics of equality. Puri (2004) argues that "'equality" is a necessarily open-ended term, the 
meanings, reach and sites of which may continually expand through social struggles" (2). Consequently, she emphasizes that the study of the discourse of hybridity and our conceptions of particular understandings of articulations of hybridity, must be studied in relation to the performance, perceptions and the everyday practices in the context in which they are inherently found. My central assertion in this chapter is that within the context of nationalist discourses of hybridity, statist policies that claim to address underlying issues of racial inequalities but do not address inherent racial hierarchy in lived narratives of citizens are not corrective at all in nature. Therefore, affirmative action policies in Brazil in its enforcement documentarily need to be examined in relation to the inherent national discursive ideologies of racial democracy that has longstanding served as an instrumentality of state oppression and suppression. There is much to be gained by analyzing the cultural politics of African descendant people in the Americas using this lens. Thus, I do not examine the changing state policies of racial and cultural politics in the Latin America and Caribbean region under the dehistoricizing and conflated term of "hybridity. Instead, I suggest that the use of conceptual and analytic term that capture localized specificities in cultural politics. In this dissertation, I propose the analytic Afro-Brasilidade Space to capture specificities, performance and historiographies within local contexts, as opposed to any generalized terms that may be arbitrarily subsumed under hybridity. Configuring the notion of mixture or "hybridity" towards a concept or an analytic helps to resolve some of the tensions between racial representation and cultural politics, by acknowledging the significance of cultural politics and cultural studies. Emphatically, the study of the cultural practices of Afro-descendant people in the Latin American and Caribbean region, especially their music and dance 
practices of Afro-Latinx people, requires a space specific analytic where cultural hybridity is concerned.

This goal of this chapter is twofold: The first goal is to familiarize the reader with the ways in which notions of hybridity have been imagined within Postcolonial Studies. Mostly, it has been imagined as dehistoricizing discourses that fails to draw attention to the historical specificities of racial inequalities. It also fails to portray various forms of cultural hybridities that are often ignored under sweeping claims of essentialisms and reductionisms. The second goal of the chapter is to argue for the need to re-conceptualize Latin American and Caribbean Studies as well as Postcolonial Studies away from concerns of syncretism and hybridity that are too overly generalized. As aptly put by Ella Shohat in her "Notes on the Post-Colonial",

A celebration of syncretism and hybridity per se, if not articulated in conjunction with questions of hegemony and neo-colonial power relations, runs the risk of appearing to sanctify the fait accompli of colonial violence. ...As a descriptive catch-all term, hybridity per se fails to discriminate between the diverse modalities of hybridity, for example, forced assimilation, internalized self-rejection, political cooptation, social conformism, cultural mimicry, and creative transcendence (Shohat 1992, 109-110).

Shohat's assertion is impactful in highlighting the various epistemologies of cultural hybridity and how that relates to the politics of representation. Enunciations of music and dance forms are vital to this discussion because they are generative of discourse of hybridity. The need to reformulate the current understandings of hybridity surfaces because for instance, the roles of the myth of racial democracy "become clearer [only] in relation to discourses of ...negrismo, [Afro-brasilidade]..." as it pertains to the resistance of Afro-Brazilian musical practices such as reggaeir@ismo, which is the lens 
of this dissertation research (Puri 2004, 5). My examination of reggaeir@ musical practices, which I define as the entire spectrum of practices that is not limited to the performative, cultural, identificatory, spatial etc., that form dialogic relationship with roots reggae music in São Luis appears to have many functions. I use the scholarly conversations in Postcolonial Studies about hybridity as a lens to situate and theoretically engage the performance space of reggaeir@s, and to explore the cultural politics of reggaeir@ismo.

This research touches a longstanding interest in racial and national identities and how it relates to the issues of cultural hybridity especially under the institution of affirmative action policies. Brazil is a key place to address these subjects because of the following reasons: Firstly, the conception of Brazil's nationhood has been discursively conceived under discursive hybridized ideology of racial democracy, which is traced under the terms of race but also in terms of culture. In Brazil, as in other Latin American nations with similar histories, representations of hybridity have been vastly deployed in many ways that has impacted the rights of black and indigenous communities. In the early part of the 2000s, after the nation's first universities adopted quotas for AfroBrazilians and other marginalized groups, Brazil implemented the most sweeping affirmative action policies in the Western Hemisphere.

On the surface, the politics of race in Brazil seem to have changed. Conversations surrounding race, especially on the national level no longer comes across as proscribed in various spaces. For a nation that long hailed itself as a racial democracy and free of racism, Brazil has had to confront the realities of its racially subjugated population. With the inception of the affirmative action policies era, discussions of racial inequalities and 
racism have been prioritized in national politics of representation (Telles 2004). As such, more spaces have been opened that allows renewed conversations about citizenship, rights and ways of belonging in Brazil's national peoplehood. In line with these policies, the state engages in symbolic practices of rituals of racial tolerance, however it also differentially incorporates Afro-Brazilians into the structural social and political economy that is justified on racial grounds. So, in the public sphere, blacks have been noticeably grafted into the national fabric of Brazil through various policies. For instance, in 2003 and 2010 respectively, the Lula and Dilma administrations enacted the Secretariat for the Political Promotion of Racial Equality (SEPPIR) and institution of the Statute of Racial Equality (Estatuto de Igualdade Racial) that incredibly transformed the way issues of races are addressed on the federal level.

Moreover, Law 12.288 that implements the Statute of Racial Equality expanded the ways in which state can implement federal programs that redress and prosecute racial inequality and racism ${ }^{1}$. Programs that have dramatically increased access to class upward mobility also accompanied the state's affirmative action provisions. The successful implementation of social welfare programs like the Bolsa Familia ${ }^{2}$ has positively impacted poverty in Brazil by reducing it at the rate of fifty percent, touching over eleven million impoverished people (Soares, Ribas, and Osório 2010). The bolsa has undeniably been helpful to Afro-Brazilians who accounted for the majority of the population living in poverty. For the first time in decades several black families have been able to socioeconomically move up in their class status to middle and upper-middle class (ibid).

${ }^{1}$ http://www.planalto.gov.br/ccivil_03/_Ato2007-2010/2010/Lei/L12288.htm. ${ }^{2}$ Lula's conditional cash-transfer welfare program enacted in 2003 deemed the most successful program of its kind in the world. 
In the field of education, affirmative action quotas implemented at the university level have afforded many Afro-Brazilians the access to higher education. The racial quotas in federal employment have also increased black visibility and socioeconomic access to spaces that Afro-Brazilians never had before. Furthermore, legislations such as Law 10.639 that mandates that African and Afro-Brazilian culture be incorporated into the academic curriculum, amongst other sweeping affirmative action employment and visibility policies in media, Brazil's racial politics on its face seem to have taken turn for the better. However, a careful analysis of these policies may prove otherwise. Here, my argument is that Brazil's hybridized discourse of racial democracy still persists even with the implementation of affirmative action policies because the affirmative action policies employ the trope of equal rights that do not translate into practice. Under Brazil's hybridized discourse of racial democracy, Afro-Brazilians are discursively included in the space of citizenship through the denial of their blackness. At the same time, under the discourse of racial democracy, Afro-Brazilians are differentially incorporated into the social and political economy that is justified on racial grounds, which is a contradiction.

The contradiction lies in the quotidian realities of black people having unequal rights as manifested especially in the documentary practice of policing their performative spaces (as I discuss later in this chapter). Hence, affirmative action as statist discourse is Brazil's reactive crisis management tool necessitated by the contradictions. At best, affirmative action in Brazil has served to increase black visibility in certain spaces. However, the pronounced visibility does not necessarily translate into complete inclusion, neither does it warrant epistemological acknowledgement of psychic presence (Phelan 1993). 
My contention here is that the statist discourse of affirmative action mainly manages the realities of racial disparities by attempting to obscure the contradictions of the discourse of racial democracy while it simultaneously maintains the racial hierarchical order imposed by the hybridity discourse. The inclusion that affirmative action promises Brazil's black population follows the notion of visibility of black bodies in spaces that fits into longstanding discourse of hybridity. As echoed by Rahier (2014, 146) and Hale (2004), the turn in racial politics in the Latin America region in general is that of change that creates the "negro permitido" (tolerated black) ${ }^{3}$, which in fact is a “populist manipulation of blackness for political gain”. As Hale (2004) argues, often

times, this notion of tolerability requires that the population seeking equal rights from the state needs to stay within the confines of the hegemonic power structure of the state. And so, the ways in which black people seek to belong within that power structure, especially culturally often challenges the state's discursive notions of citizenship, even under the equal rights trope of affirmative action.

Musical practices as widespread forms of cultural expression are complexly connected to national identity, however one must be understood in relation to the other. Additionally, these connections must also be understood in relation to transnational circuits of cultural exchange (Wade 2000)

\section{Policia Militar vs. Black Bodies}

Amidst the implementation of affirmative action policies, Brazilian states continue to violently police and systematically kill poor black people in certain spaces (Cavallaro and Manuel 1997, Paes-Machado and Noronha 2002). The lived realities of

${ }^{3}$ See Hale's (2004) notion of indio permitido (permissible Indian). 
the majority of Afro-Brazilians are that the violent policing by the policia militar follows a hegemonic discourse of public safety that criminalizes black bodies and their performative spaces.

Recent national studies show that Maranhão is one of the most violent places to live in Brazil (Mesquita Neto 2000). According to the statistics of the Fórum Brasileiro de Segurança Pública (FBSP 2013), the state of Maranhão had the second highest index of police-related homicide in the nation (this includes both the policia civil and policia military) ${ }^{4}$ In 2012, the civil police killed 80 people and the military police killed 472 people in the state of Maranhão (FBSP 2013, 40), In 2015, the civil police killed 80 people and the military killed 490 people, of these killings $25 \%$ were related to the reggae music scene in the state (ibid.) These statistics juxtaposed with the number of police offers killed in the line of duty shows a huge disparity: In 2012, eight military police officers were killed in line of duty in Maranhão (ibid.) In 2015, no civil police officers were killed in line of duty, two military police officers died in line of duty (ibid.).

The classification of these killings is telling of the state's view of death of poor black population. When Brazilian law enforcement catalogues police killing, they do so by three groups: resistencia seguida de morte (resistance followed by death), autos de resistência seguidos de morte (acts of resistance followed by death) and morte em confront (death in confrontation). In the interpretation of these numbers and

\footnotetext{
${ }^{4}$ The Brazilian police are organized into three different categories, two of which fall under the purview of the secretary of public security and operate at the state level: policia civil and policia military. The third body is under the control of the federal government even at the state level, the federal police. The civil police are responsible for criminal investigation and administrative policing. The military police are uniformed foot patrols that are responsible for the quotidian surveillance in neighborhoods, arrest, and general criminal activities.
} 
classifications, police homicides are viewed as victim suicides where the onus of the cause of death is based on what the victim did and not the action of the police (FBSP 2013, 120). Violent policing and direct aggressive action at the hands of the state is an intricate part of the culture of safety in Brazil that distinguishes it from other nations known for violent racial profiling. (Chevigny 1999).

My argument here is that inherent in the statist discourse of racial democracy and hybridity are the contradictions of racial inequalities, as manifest in violent policing in black performative spaces. Consequently, the statist discourse of affirmative action attempts to reactively manage these contradictions by obscuring the crisis of violence against black bodies with social reforms that thwart the advances of equal rights for AfroBrazilians. Here, I also argue that these contradictions are best assessed in the localized processes of hybridity. In the succeeding paragraphs, using the localized experiences of reggaeir@s in their performative spaces as a lens, I analyze the various ways in which the performatives spaces of reggaeir@s contest and challenge the national discourses of belonging and citizenship in Brazil.

\section{Defining Difference Under Statist Discourse}

A critical part of this dissertation hinges on the argument that mestiçagem and its conjoining notions of racial democracy is an ideology produced out of a discursive framework of racial hybridization that distorts processes of entanglement produced out of contact. In this section of the dissertation I delineate the analytical framework of this work and how it fits into the scholarship of hybridity. Firstly, I trace how hybridity as ideology and discourse has been invoked and critiqued in scholarship. I then focus on my arguments on scholarship that address hybridity in the localized context, particularly 
Shalini Puri's work on hybridity. This dissertation is beholden to the work of Puri's work on hybridity, and her call to reformulate hybridity that speaks to the interactions of local specificities with relations of power. However, my work seeks to add to Puri's conceptions of redefining the examination of hybridity by inserting the dialogic specificities of Afro-Brasilidade Space and how that relates to the performative space of reggaeir@s. I suggest a reframing of hybridity that looks at how ways of belonging are defined by Afro-Brazilians under affirmative action policies. This opens up the field of interrogation in Latin American Studies with regard to definitions of citizenship while also offering new directions and possibilities for cultural studies in Brazil.

A paramount part of my argument is that the borrowings and recreations of black culture from different parts of other Afrodiasporic cultures represent more than the strength of survival and the creative possibilities of local black populations. In Brazil, Afro-Ludovicenses borrowings from other Afrodiasporic spaces like the Caribbean connote a long history of contact between Brazil and other Afrodiasporic populations. As I detail later in my discussion of Afro-brasilidade Space, -Afro-Brazilians draw on this history of contact to shape black subjectivities and cultural politics what has been defined by Lipsitz (1994) and Gilroy (1993) as "diasporic intimacy." They assert that diasporic intimacy comes about from the various ways in which Afro-descent persons from different spaces in the African Diaspora cultivate notions of kinship with one another. The perception of kinship is attributed to notions such as perceptions of relatedness of similar sociocultural relationships and perceptions of experiencing familiar forms of societal oppression or suppression. Gilroy (1993) claims that this perception of kinship with others in the African Diaspora is what marks the recurrent creation of black 
subjectivity outside of modernity. ${ }^{5}$ To this end, diasporic intimacy is not about flagrant imitation or impressionism, however it is about being Afro-Brazilian that is dialogically defined outside Brazilian statist discourse.

This portion of this chapter is divided into four sections. The first section will examine theories of hybridity to suggest the ways in which Afro-Brazilian cultural politics of identity fit into this conversation of hybridity that incorporates this dissertation project. The second section, building on Puri will suggest the emphasis to focus on local specificities of hybridity especially as it pertains to cultural politics and musical performativity as the lens of this project demands. The third section examines the hybridized discourses of mestiçagem and creolization as it has been theoretically approached in the Latin and America and Caribbean region. I discuss these two discourses theoretically and how their critiques have been used to analyze and interpret hybridity in Latin American cultures and identities. With my discussion of mestiçagem, I suggest that in highlighting of the importance of hybridity of the scholarship of roots reggae musical practices in São Luis, I do not mean to ignore the problematic ways that mestiçagem as ideology and discourse have been employed in the past to mask persist racial inequalities. Instead, I discuss mestiçagem as discourse that has provided useful approaches to analyzing racial and cultural hybridity. Similarly, I discuss the various approaches that creolization as discourse and ideology has been used in scholarship in the Latin America and Caribbean region. I focus on this discussion of creolization scholarship in order to distinguish Brazilian affirmative action policies from the

\footnotetext{
5 See Gilory (1987) There Ain't No Black in the Union Jack for further discussion of how black British people create notions of blackness by employing "raw materials" from other spaces of the African Diaspora
} 
multiculturalist policies in the region. I argue that although mestiçagem as discourse of hybridity has offered approaches to analyzing hybridity theoretically and discursively, it does not map neatly onto the domain of the sociocultural and sociopolitical performancescape of Latin America and its inherent musical practices. In the latter portion of the chapter, I discuss why creolization as proposed by Glissant (1989) offers a better analytic to discuss reggaeir@performativity.

\section{Section I: Theorizing Hybridity and Difference:}

Theories of hybridity have served to weaken arguments that privilege cultural origins and notions of cultural purity. The scholarship on hybridization in postcolonial studies has been varying, namely, cultural, political, racial, and linguistic and the like. For instance, cultural theorist Bakhtin (1981) asserts the notion of linguistic hybridity where he demonstrates the ways in which the disruptive and transfiguring power of double-voiced language operates. This idea of many voices in the society is also implicated in Bakhtin's Middle Age concept of the carnivalesque when "boundless world of humorous forms and manifestations opposed the official and serious tone of medieval ecclesiastical and feudal culture" (Clark and Holquist 1984, 4).

Postcolonial theorists of hybridity like Anzaldúa (1987), Hall (1990), and Bhabha (1994) have invoked these concepts of mixture as way of analyzing new identities and subjectivities that emerged from colonization and continued projects of racial domination. Bhabha presents a notion of hybridity that emerges from literary and cultural theory where he argues that the governing bodies (colonizer) interpret the identity of the "Other" (colonized) in conjunction with essentialist beliefs. The colonizer's "translative" 
project creates a hybrid that is neither familiar to the colonizer nor the colonized (Papastergiadis, 1997).

Bhabha characterizes the colonizer's relationship to the colonized as interdependent and mutual in their construction of their subjectivities. Bhabha (1994) problematizes the danger in attempting to study cultural diversity under the notions of universal concepts or labels, such as " "human being", "class", or "race", which he sees as both dangerous and limiting in trying to understand the ways in which cultural practices construct their own systems of meaning and organization" (209). He argues that all cultural systems and practices are constructed in the contradictory and ambivalent space that he calls "Third Space of enunciation" (ibid, 37). He asserts that the controversies in a multicultural society are unavoidable and inevitable in that the acceptance of this fact helps us to overcome the exoticism of cultural diversity:

It is significant that the productive capacities of this Third Space have a colonial or postcolonial provenance. For a willingness to descend into that alien territory... may open the way to conceptualizing an international culture, based not on the exoticism of multiculturalism or the diversity of cultures, but on the inscription and articulation of culture's hybridity (Bhabha 1994: 38)

In sum, for Bhabha, the significance of the notion of hybridity lies in the ambivalent space that carried the burden and meaning of culture. In instances where hybridity has been used in post-colonial discourse to indicate cross-cultural exchange, the term has been criticized for failing to account for the imbalance of power in relations implicated. Where hybridity emphasizes the transformative, political and linguistic impact on the colonizer-colonized relation, the use of hybridity in this way has been criticized for reproducing assimilationist policies by obscuring cultural differences. Moreover, where 
hybridity has been used to delineate cultural mutuality as in processes of cultural synergy, syncretism and transculturation, proponents of decolonization and anti-colonialism, the use of the concept in this way has been cited to deemphasize oppositionality in favor of postcolonial dependence.

Here, my primary concern is with constitutive interactions between the dominant power and oppressed. Within the confines of power relations, I am interested in the extent to which the colonizer's translative project of the "Other's" identity is imbricated in the enunciated practices of the oppressed that simultaneously challenge and reproduce the essentialist constructed identities. My point here is not to coerce the reader to perceive the discursive formation of the othered identity as a deliberate project. Instead, it is to point to the sliding ambivalent nature of power dynamics that impacts epistemological othering in colonialist discourse. Moreover, I suggest a close examination of the ways of knowing that constructs hybrid cultures and identities that are not always seen as resistance.

Yet another critique of how hybridity has been conceptualized is where it has discursively been used to show a shared post-colonial condition. Employing hybridity in this way has been seen as a broad or abstract generalization where cultures have been dislocated and dishistoricized from their geographical, temporal, linguistic and spatial contexts. However, this critique can also be criticized in that it in highlighting how colonial discourse is constructed, one does not seek to mask other ways of investigating culture. Young (1995) supports this reasoning by pointing out that other forms of analysis are already embedded in the contribution of colonial discourse analysis: 
"[Colonial discourse analysis] provides a significant framework for that other work by emphasizing that all perspectives on colonialism share and have to deal with a common discursive medium which was also that of colonialism itself...Colonial discourse analysis can therefore look at the wide variety of texts of colonialism as something more than mere documentation or "evidence". (Young 1995, 163)

Nevertheless, Young (1995) also provides several objections to the arbitrary use of the term hybridity. He emphasizes how at the turn of the century in imperial and colonial discourse accounts, hybridity was used to portray the mixing of disparate races as requiring attention because of their tendency to reverse to primitiveness. While noting the difference between hybridizing processes such as creolization that occurs unconsciously and in politically motivated and deliberate processes that consciously disrupt homogeneity, Young is particularly concerned with the dangers of using the term hybridity in ways that were previously imbedded in racist assumptions. Young (1995) engages Bahktin's use of hybridity by pointing out how hybridity is politicized but also made contestatory in ways that allows for challenge of division and separation. He states that Bakhtin's uses of the term "sets different points of view against each other in a conflictual structure, which retains "certain elemental, organic energy and openendedness"' (Young 1995: 21-22). Young (1995) also elucidates how Bhabha accounts for structures of domination in the colonial situation as follows:

"Bakhtin's intentional hybrid has been transformed by Bhabha into an active moment of challenge and resistance against a dominant colonial power...depriving the imposed imperialist culture, not only of the authority that it has for a long imposed politically, often through violence, but even of its own claims to authenticity (23).

Additionally, Young is concerned about the unconscious process of repetition that is associated with the contemporary use of term hybrid. He argues that in contemporary 
cultural discourse, scholars are often inclined to make connections with historical categories of race with very particular meanings. Consequently, Young insists that the connections to past racial categories is inevitable such that in "deconstructing such essentialist notions of race today we may be repeating the past than distancing ourselves from it, or providing a critique of it" (27).

In general, in arguing for an active decolonizing project especially in relation to national culture and pre-colonial traditions, theories of hybridization of post-colonial culture have averred models of resistance by locating the subversive counter-discursive practices as implicit in the colonial ambivalences in the national cultures and pre-colonial traditions. In decolonizing of discourse analysis, my main interest here in engaging with theories of hybridization is to examine what constitutes "resistance" or "agency" in the dialogic interactions between the political and cultural discourses of dominant entities such as state power and responsive enunciative practices and traditions of the oppressed, especially in the performance of race and culture.

\section{Section II: Localizing Hybridity and its Conceptions in Postcolonial Theory}

Of vital significance to this dissertation is Puri's (2004) intervention on the use the concept of hybridity in postcolonial theory. She problematizes the notion of hybridity as a unitary heading that has been given to a multitude of contingent political possibilities specified in various local contexts. Puri emphasizes the importance of localizing hybridity, which means locating the theoretical concept within the history of the discourse. It also means that the hybrid forms and the theories about the hybrids are to be viewed as relative, not abstractly theoretical. In engaging the relative links between the 
hybrid forms and the theories about them, she purports the significance of showing how they engage with a "specific" local cultural and political context.

Without being distracted with the recurrent debates over "Subaltern Studies", of equal interest to my work here is the level of attention that Puri gives to local histories as she takes up the challenge of responding to Latin American Studies' scholars need for Cultural Studies, which is inspired by her concern for social equality. Even though Puri (2004) focuses on the culture of politics of several individual nations in the Caribbean, the scale of her analyses are concentrated on the national, which allows her to center her critiques on specific cultural communities and how they are impacted by these specific state policies. At the same time, because Puri analyzes several nations in the Caribbean, giving attention to each space on localized scale, her work also has region and transnational implications in comparison. She addresses the question of whether postcolonial theory, with its foundational lens in Indian critiques to British colonialism, offers useful models for Caribbean nations, where the impacts of European colonization have left different legacies on nation building and cultural practices. Puri believes the Caribbean, especially non-Anglophone Caribbean has, “...been marginalized from the canon of Postcolonial studies still dominated by the English Crown and still often conceived in terms of East/West binaries. The Caribbean...can deepen our understanding of hybridity conceived neither in exclusively East/West, nor even North/South term" (7).

Puri's situational work provides room for scholarly interventions of hybridity in Latin American and Cultural Studies on her readings of social inequality uncontested by nationalist hybridity discourses. In Latin America, narratives of hybridity have been synonymous with projects of whitening and ideologies of racial democracy deployed 
strategically to the end of consolidating power within a particular population of citizens. For many in Latin American Studies, hybridity has been historicized as the most recent in series of similar cultural discourses. For instance, Alberto Moreira's (1999) subalternist critique of hybridity explains the relationships between the various sequential discourses of culture, which is mestiçagem, transculturation, heterogeneity, hybridity, and the changes that are occurring in the formation of the nation-states in Latin America. Néstor Garcia Canclini's (2005) intervention in the Latin American Cultural Studies scholarship addresses an interdisciplinary approach to cultural discourses of hybridity as it relates to the neoliberal state. Moreira (1999) contends with the inclination to argue “...for hybridity against a reification of cultural identities as some kind of recipe for perpetual flexibility" (1). Canclini argues that although many Latin Americanist scholars have presented hybridity as a cure-all to the exclusionary practices inherent in the national discourses of cultural purity seen in many nation-states in Latin America, hybridity as discourse and ideology historically may also be exclusionary and marginalizing in itself. For Canclini (2005), hybridity historically has posed "a sort of ideological cover for capitalist reterrritorialization - and even a key conceptual instrument for the very process of naturalization of subaltern exclusion (2).

Moreira's (1999) arguments appear to be addressing two different levels of questioning the claims of hybridity: Firstly, he asserts that hybridity can be limiting politically when political action excludes those who are seen as less hybrid or those who are hybrid in non-familiar ways, such as tradition or neotradition rural groups. Secondly, hybridity can conceptually become limiting as a lens as it leaves room to discard significant imbalances simply as structural inequalities of hybridization. His contentions 
in this sense seem to argue that hybridity as discourse becomes limiting when it conceptually reifies the failing practices of politics even as it claims to celebrate diversity. Furthermore, Moreiras relies on Kraniauskas (1992) argumentation that hybridity discourse tends to convert national failure into "diversity" by ascribing inequalities within the nation to generalized notions of "difference"

Moreiras' (1999) critique of hybridity discourses and the need to focus on socioeconomic realities in the nation appears to bear profound similarity to Puri's argumentation of locating hybridity in localized realities. However, Puri's contentions in this way depart from Moreira's critique in at least two ways: Firstly, Moreiras places his arguments within the context of Cultural Studies and Latin American Studies while Puri places her arguments in Caribbean Studies (albeit generalizable to other regional studies). This difference is worth noting because Puri appears to be using hybridity to refer to a historical range of theoretical discourses and practices that includes mestiçagem, rather than Canclini's recent theories about the neoliberal state and hybridity alone. Secondly, the other difference, which is more far-reaching, between Puri's critique of hybridity and Moreiras' critique has been the role that hybridity has played theoretically. Because Puri proposes argumentation about hybridity that is demystified of the abstractness often attributed to it as discourse and ideology, it appears to be very similar to the Moreiras subalternist contentions about hybridity as described above.

However, Puri's perspectives oppose Moreiras views that the limitations of hybridity and its imbrication with established political interests can be conceptually

\footnotetext{
${ }^{6}$ See John Kraniauskas, "Hybridity and reterritorialization,” Travesía 1, no. 2 (1992): 150, quoted in Moreiras, 376
} 
resolved with counter-concepts. Contrastingly, Puri's approach depends on the importance of understanding hybridities in their local contexts, rather than abstracting them into generalizable principles or counter-principles. For Moreiras (1999), the concept of subalterneity held out the promise to finding a counter-concept that corrected the limitations of hybridity. Puri (2004) engages a historicist deconstruction of hybridity in Caribbean Studies through the lens of the locale and a Marxist commitment to lived realities and social inequalities of the population she identifies as "subalterns". However, she does not achieve this end with a suggested replacement theoretical discourse of subalterneity as Moreiras proposes.

For Puri, in tandem with state power or against it, non-agentive forms become agentive when a nuanced sense of the complex agency of cultural actants is reinstated. The ways in which hybridity has been depoliticized is fundamental to Puri's arguments: She claims that hybridity has been conceptually transformed into an abstract principle, and through this transformation hybrid social forms are removed from any local context they arise in attempts to generalize them into a global ideal. Puri emphasizes that when hybridity is removed from local contexts, all sorts of racial inequalities, political imbalances, police brutality and various other contested histories become lost in the removal process. That is to say, removing hybridity from the local context does not only depoliticize the hybrid within the nation, but it also deemphasizes the importance the contributions of the nation-state.

\section{Section IIa: Conceptualizing Hybridity in the Contemporaneous Locale}

In postcolonial theory, hybridity as discourse appears to have two ways of relating to time: "either hybridity uncovers multiple sources for allegedly homogenous cultural 
entities and thus set in motion alternative historiographies, or hybridization as history-inthe-making orchestrates its own process of forgetfulness, recasting a multiplicity of practices into a new context" (Coundouriotis, 2006). Puri (2004) argues that the ways in which major theorists of hybridity have approached notions of the nation-state has been by showing "evidence of the undermining or transcendence of the nation-state" (19).

Where theories of hybridity deemphasize the importance of nation-state with regard to its sociocultural and socioeconomic analysis, postnationalism is offered as a substitute. However Puri finds postnationalism to be an insufficient replacement for nationalism because through documentary practices nation-states continue to exert control over sociocultural and socioeconomic forces. Additionally, in practice, postnationalist discourses tend to mask inequalities that are inherent in the social forms that they imagine. Puri (2004) demonstrates how Bhabha (2001), Anzaldúa (1987) and Gilroy (2000) have used hybridity; she says that they have analyzed hybridity as a way of contesting the homogenizing tendency of traditional nationalisms as well as of undercutting the inclination of postcolonial resistance theory towards reductive binarism (38). She further critiques their metropolitan perspective on hybridity, which locate hybridity as external resistance that privileges the very core of their deconstructions by failing to give priority of the hybrid as its own sphere. Puri asserts that scholars like Anzaldúa, Bhabha, and Gilroy share "the theoretical construction of hybridity as principle of difference abstracted from historical specificities" (25).

In this dissertation, I place my work in conversation with Puri's analysis of hybridity as ideology and discourse that are contradictory, ambiguous and polyvalent. In analyzing the cultural politics of representation of reggaeir@s in São Luis, my work 
contributes to the knowledge of popular music culture in Cultural Studies as I engage the statist discourses of racial democracy and affirmative action. In analyzing how the politics of representation in Latin America are engaged with the contesting nationalist discourses of hybridization, while focusing on the localized nuances of reggaeir@s representational politics, I engage Puri’s analytical framework in analyzing hybridity while remaining committed to localized histories.

In addressing the lived realities of police violence in reggaeir@ spaces specifically, I contribute to the work of critical theory in addressing the pitfalls of postcolonial theory that hastily applies hybridity to the generalized cultural field of Latin American. According to Puri, the rush to celebrate a theoretical postcolonial hybridity seems to have reproduced the denials of inequalities in the many national contexts. It is important to note that even though Puri argues against the approach of postcolonial theory in generalizing hybridity into a politically global principle, she also engages Glissant's work, which does not dissociate postcolonial hybridity from its local context. Puri engages with Glissant's conception of "forced poetics", which is "a poetics internally divided, desire and expression at odds with one another" (84), to construct her argument about the contradictory and artistic visions of postcolonial theory. She stresses the nuances of Glissant's arguments about hybridity and difference by stating that:

One of the strengths of Glissant's theory of hybrid antillanite is that its project of "making relative" is the very antithesis of relativism; instead, it is a "return to the point of entanglement" to decipher the complex relation of Caribbean particularity to globality. Creolization for Glissant thus becomes a method of articulating a non-relativist conception of difference (77). 
Here, Puri emphasizes the "return to the point of entanglement" in geographical terms, in her case the Caribbean in the global. However, the return is also historical to a past moment of engagement that needs to be revisited. I tie this argument of historical entanglements with Glissant's notion of rhizome. Glissant (1997) suggests that that all diasporic cultures are the product of a rhizome - meaning that the historical event of a place shapes the cultural and identity formation of its people in different ways. Consequently for people of African descent, there is no single black or diasporic experience. As there are many historical landscapes in which African descendants have survived to produce their hybrid cultures. As an analytical framework for this project, I assess the various historical experiences that has produced reggaeir@ identity and performance spaces. Furthermore, tying Puri's theoretical frame of hybrid into that of Glissant's rhizome, I argue that the local sensibilities that inform the reggaeir@, performance space are informed through diasporic articulations of blackness and linkages with global blackness.

Here, it is important that I discuss my conception of Afro-Maranhese or AfroLudovicense people and musical practices as hybrid. In doing so, I first examine why theories of hybridity such as mestiçagem, which has long been engaged to analyze hybridity in Latin American and Caribbean cultures does not fit well in discussing the political landscape of affirmative action in which Afro-Maranhese and reggaeirism@as music and dance practices are rooted. In the next section of this chapter, I address the pitfalls of the conception of mestiçagem and the impacts that it materially has on AfroBrazilian musical practices. 
In this dissertation, I suggest that performance in São Luis do Maranhão is informed by other Afrodiasporic spaces of blackness. Furthermore, tied to this model of global blackness is the tendency to see hybrids as cultural critiques of the nation. With respect to Afro-Maranhese appropriation of Black Atlantic culture such as roots reggae, Dunn (2004) argues, “cultural processes related to a transnational diasporic hybridity would function as a critique of an established notion of hybridity (e.g. mestiçagem) associated with national identity" (83). I argue that reggaeir@ identity and performativity can be seen in a similar light. Gilroy (2000), Bhabha (1994) and Hall (1996) have explored the idea of diasporic hybridity as contesting essentialist, bounded identities. Dunn (2004) intervenes in this conversation with a Latin Americanist perspective by showing how a diasporic version of hybridity can challenge standard, nationalist versions of hybridity that are based on notions of the syncretic synthesis of bounded identities in a dialetic of reconciliation (See also Young 1995). As I have discussed above, Puri (2004) argues that hybridity itself, even in diasporic forms, may sit easily with post-modern forms of power, which no longer rely on binary divisions and dialectical reconciliation (Hardt and Negri 2000). In this light, I explore how reggaeir@ performatives are articulated complicitly with state hybridized articulations of affirmative action policies at the local level.

\section{Section II: Discourse and Ideology: Mestiçagem, Creolization and Popular Culture}

Fundamentally, Afro-Maranhese may be classified as a hybrid people: as I have discussed in detail in the second chapter of this dissertation; they are genetically as well culturally the products of European (French, Dutch and Portuguese), African slaves and Indigenous peoples. The term mestiço has been used in Latin America to describe 
populations and culture of mixed Indigenous and European ancestry. The associated term mestiçagem as a hybrid term has often been used to refer to the process of cultural mixing that followed biological hybridity. In principle, these terms may used to refer to people and cultural mixture of people of African and European descent. However, in practice, mestiçagem is associated with European-indigenous hybridity. The corresponding term for African-European hybridity had been, albeit rarely, mulatto, instead the term "creole" has been substituted in the Americas to signify the hybridity that resulted from European conquest, slavery and continued colonization but not necessarily referencing race. For instance, Bilby (1985) defines "creolization" as the "meeting and blending of two or more older traditions on new soil, and subsequent elaboration of form" (182). Correspondingly, Davis (1994) has also conceptualized the "creole" as "a cultural conglomerate born of Old World parentage and tempered by New World circumstance and creativity" (120). Even though the terms "creole" and "creolization" may be employed to refer to mixtures seen as mestiço and "mestiçagem", creole/creolization is rarely used in spaces where mixtures comprises of Indigenous-European ancestry in the population are higher. Similarly, mestiço/mestiçagem are terms that are rarely used to describe people and culture mixtures where African-European ancestry outweighs other mixtures in Latin America. Moreover, there is Brazilian hybridity that comprises of the tripartite mixtures of African, European and Indigenous ancestry, which has often classified under mestiçagem by many scholars (see Pancíni Hernandez 2010, Safa 1998, Wade 2000, Jiménez Román 2007).

The cultural and biological intermixings in Latin America has resulted in a plethora of hybrid musical traditions and practices. As detailed in the second chapter, 
roots reggae musical practices, alongside its Caribbean influences of merengue, bolero, compas, cumbia as well as other Brazilian, Cuban, Puerto Rican and Mexican forms such as samba, mambo, reggaeton and mariachi respectively, amongst many others genres are undeniably hybrid forms of African, European and Indigenous cultural mixtures. Although, the concept of mestiçagem has often provided theoretical approaches to analyzing racial, cultural and musical hybridity in Latin America and the Caribbean region, with regard to musical practices, it remains highly problematic. In this section of the chapter, I explore some of the approaches and critiques of mestiçagem as a hybridizing discourse that make it problematic as a framework for the analysis of musical practices. The ultimate aim of this project is to demonstrate how forms of localized performatives in music challenge and contradict national discourse of racial democracy that is inscribed in policies and practices of affirmative action. As such, after I discuss the discourses and ideologies of mestiçagem and creolization, I transition into the theoretical discussions of why I suggest Afro-Brasilidade Space as an analytic that will be better suited for this project, following the framework of Puri (2004) in "localizing hybridity" arguments.

\section{Examining Mesticagem as discourse and Ideology in Latin America Popular Culture}

As a theoretical framework, mestiçagem has provided approaches to analyzing musical practices in Latin America. However, many scholars of race relations in Latin America have also gravely critiqued its theoretical notions mainly for its underlying implications and harmful consequences when it comes its sustenance of racial democracies in the region (Safa 1998; Pancíni Hernández 2010; Dzidzienyo and Oboler 2005). Their critiques principally stem from the dangers of the hybridized discourse of 
racial democracy that arises from mestiçagem that propagates and maintains discourse of racial difference through essentialist notion of race among its constituent parts. Pancíni Hernandez (2010) argues that mestiçagem leads with the trope of ... "we are all mixed so we are all equal" [that] has long been used in Latin America to avoid facing (and altering) the social, economic, and political structures responsible for perpetuating raced-based "pigmentocracies", in which white-skinned individuals enjoy privileges of every sort; mixed-race people occupy an intermediate space depending such variables as their phenotypical proximity to whiteness, education, wealth, and so forth; and people of more unambiguously African or native ancestry are subject to subordination and exploitation (933).

Pancíni Hernández has also suggested that the notions of mestiçagem and its critiques are problematic when it comes to using the analysis of music. Citing Jiménez Román (2007), Pancíni Hernández argues that mestiçagem’s ““'role in perpetuating racial inequalities in Latin America, observes that attempts to identify an individual's constituent parts account for the "assiduous attention paid to the phenotypical details that "expose" African "genes and for the elaborate vocabulary that at once confers privilege and derides the subject under scrutiny. The conceptual difference between "high yellow" and "grifa" [both terms for a lighter shade of skin color] is truly insignificant and responds to the same historical privileging of certain physical characteristics over others"”' (Jiménez Román 2007, 329 cited in Pancíni Hernández 2010, 933).

Pancíni Hernández argues further that although Jiménez Román's assertions about the specific origins of a person's phenotype may as valid, it is only valid and helpful within the context that she describes. That is to say that other scholars may not find her analytic helpful in identifying the componential origins of musical practices in Latin America. She argues for instance, that musicians performing African drumming may be 
of any hue in skin color. As such, in order to find the source of African-derived drumming in a particular style of music in Latin America, the implications of mestiçagem as Jiménez Román describes would have the same impact as finding the roots of a person's skin color in other contexts.

Pancíni furthers her argument as to how mestiçagem as a hybridizing discourse fails to map neatly into the domain of music by asserting that where musical practices are characterized by the aesthetic mixing of other forms to achieve another recognized form, that process could not be equated with the racist aims of branqueamento (racial whitening), which aims to "improve the race" by "whitening" it" (ibid, 934). She also does not deny that processes are insidious notions of hybridity that are inherent in nationalist discourse of mestiçagem and it impacts on the domain of popular music in Latin America. In agreement with $(1989,2011)$ and Wade (2000), Pancíni acknowledges that where concepts of hybridity embedded in mestiçagem has influenced national ideologies pertaining to music, it has been the source of racist ideologies in the realm of popular music. Scholars like Daniel (2011) Crook (2005) and Wade (2000) have extensively examined nationalist ideologies of mestiçagem that have functioned to uplift archetypal hybrid musical forms such as Brazilian samba, Dominican merengue, Cuban son, Colombian cumbia amongst others as national symbols of identity. Through racist ideologies of mestiçagem, many appropriate many of these musical forms from societally oppressed groups by "cleaning" or musically whitening them in order to prop them up as celebrated national symbols of identity. The "whitened" versions of these musical forms are only celebrated because the constructed forms that result from the national discourse of hybridity are deemed to express the literal and figurative of racial and cultural 
mixtures as connoted by mestiçagem, irrespective of the persistence of racial disparities. Contrastingly, musical practices that are perceived as of unambiguously of indigenous and African origins do not achieve the same praise as the national hybrid forms. Here, in sum, my argument is that by highlighting the importance of hybridity for the scholarship on roots reggae culture and musical practice in São Luis

\section{Theorizing Creolization as Discourse and Ideology in Caribbean and Latin American Popular Culture}

At the end of the $19^{\text {th }}$ to the $21^{\text {st }}$ centuries, creolization and other notions of race and cultural mixings have played a dominant role in the official and hegemonic imaginations of Latin America and the Caribbean national identities. Similar to the Brazilian context described above, these ideologies of national identities have downplayed and often denied the importance of persistent racism and racial inequality by upholding the myth of racial democracy. Individuals in these societies that do not fit archetypal hybridized identities are marginalized and "othered". Irrespective of the perceived notions of inclusion and harmonious homogeneity that are associated with creolized ideologies, notions of creolization constitute narratives of white supremacy, which have always imbricated notions of whitening or branqueamento. As an analytic, creolization has been used to explain various processes of mixture, especially in the Caribbean and other nations with hybridized histories. Here, I review the discourse of creolization as it has been used and critiqued in the scholarship of the Afrodiasporic spaces. 
I then use these approaches and critiques of creolization as discourse to make a distinction between how affirmative action and multiculturalism as politics of representation in Brazil and other nations in the region.

My argument here is that musical practices, such reggaeir@ismo account for the local specificity of notions of mixture in that the processes of creolization as an analytic will only be suggestibly helpful if the pitfalls of the discourse of creolization is addressed. I use this argumentation in an attempt to suggest how musical practices cannot be perceived as "merely musical" or mundane but also to show how in the context of various statist projects, music and dance cultures engage in intricate communicative relationships with lived social narratives (Guilbault 2005).

Aside from the critical scholarship that argue for the instantiation of white supremacy and racial hierarchies in their formulation and practice, some scholarship on creolization and metissage as notions of hybridization have ignored the persistence of racial hierarchies and racial segregation. These scholarships often focus on the oppressiveness of statist strategies and other hegemonic categories or projects as the way to uplift the processes of hybridization, heralding them as the utopian ideal to end autochthonous nationalisms in the struggle for racial and cultural equality (Rahier 2003). Rahier (2003), echoing Lévi-Strauss, states that the intricacies of the processes of creolization are too complex for it to be captured under a well-defined theoretical system. However, creolization is helpful and important as concept that helps in the process of learning heterogeneous and heteronomous identities in the postcolonial context without subjecting them to essentialisms. Schechner (2000), in speaking about hybridity as it pertains to cultural performances suggests that the concept of creolization, evokes a 
multidirectional cultural prolificacy, which contravenes the purity of essentialist highbrow and lowbrow cultures.

From the perspective of some Latin American scholars, in the studying of blackness and the African diaspora cultures, the creolization discourse that intellectually celebrates cultural and racial mixings tends to blur the ideological oppressive lived realities and histories of the cultures studied (Meethan 2000, Hale 1997). Debates surrounding how the tensions between ideologies and lived realities have led to questions as to how the term applies universally and in specificity. Puri 2004), Hall (2003a) and Pratt (in Hall 2003a) have questioned whether creolization is conceptually and theoretically applicable to sociocultural practices in other areas besides the Caribbean, where it has been predominantly used. Hall (2003a) proposes using the notion of creole by approaching it from the lens of what is gained or lost in the process of generalizing the term to other spaces. Similarly, Verges (2003) calls for the use of the term by the identification of specific of principal components of creolization such as colonial power relations as it is understood in the Caribbean and the portrayal of how these components remain applicable in relations of power other spaces.

Hall (2003a) sees creolization as corrective discourse for Césaire's Negritude and so he sees the speaking of Creole languages as forms of rebellion or defiance that also serves a way of asserting one's Caribbeanness. Puri (2004) contributes to the positive perceptions of creole discourse by suggesting that while other theorists may have discursively used creolization to place the Caribbean outside of modernity, pointing to its tremendous hybridity, creolization is however utilitarian in identifying African- 
descendant populations in this society. She states that creolization serves as a positive lens that normalizes the Afro-Creole in ways that other lenses view them as deviants.

Other theorists have criticized creole discourse as way of addressing how it distorts and elides reality. Many of these scholars point to the argument that the focus on "creolizing" or fusion conceals overt inequalities and it also overshadows differences within these societies. (Hintzen 2002, Puri 2004, Hall 2003a, Mosguera 2003, Pratt1992, Rahier 2000). Consequently, Hintzen (2002) has addressed the fundamental implications of creolization discourses that espouse racialized purity. His intervention addresses how creolization has been used politically to further marginalize racialized others. He suggests that creolization discursively creates a racialized hierarchy that places Africanness on one end and Europeanness on the other, while it simultaneously favors the valorized retentions of European traits. He further explains "whiteness retains its valorized hierarchical position in a way that makes it difficult to challenge white supremacy in national constructs since we are all "creole"” (Hintzen 2002: 484). Moreover, because the cultural aspects of creolization are often embedded in the political systems, it is imbricated in " ... a mechanization for the non-problematization of whiteness, legitimizing the postcolonial version of racial capitalism" (ibid). This makes it difficult for racialized others in postcolonial creolized societies to assert the lived experiences of racial inequality as the processes of creolization maintain and in many instances magnify these postcolonial relationships.

Puri's (2004) intervention adds to Hintzen's (2002) point that cultural creolization has been discursively used to heighten the racial inequalities that exist in Caribbean societies because of its tendency to hierarchize mixtures that involved Europeanness 
above Africanness. In other words, creolization as discourse is the product of power and the use of power to construct knowledge about the creole, a figure produce out of interpellation. This raises the point that hierarchization of race is fundamental to the understanding of how creolization operates within national constructs of citizenship and peoplehood. In its mechanizations, creolization operates through the lens of the uplifting of Europeanness over Africanness, which resulted from the unequal dynamics produced out of the lived histories of the master-slave identities that existed within the slavery and the plantation system. While its predecessor discourse, négritude, attempted to shift the spectrum from the valorization of whiteness to Africanness, thereby valorizing identity or self that does not glorify the master-slave dynamic, creolization prides itself on a discursive mélange of the slave and the master relationship and all identities formations that has stemmed from that relationship (Bonniol 1997).

\section{Theorizing the processes of Creolization:}

Consequently, Benoist (1997) asserts that creolization does not exist outside of the space of cultural and social strife due to its master-slave foundations. Contrastingly, it is important to note that scholars such as Benítez Rojo and Ortiz have conceptualized creolization away from the space of plantation culture. They do not locate production of new cultural invention in the space of the plantation, which Benítez Rojo identifies as a place of violent suppression and deculturation (May 2009). Their assertions call for a non-homogeneous, non-cultural notion of creolization that is not embedded in opposition and repression with regard to the master-slave dynamic. They posit that the notion of creolization in the Caribbean is characterized by diverse experiences and perspectives 
that coalesced to form prismatic entities, mosaics, or patchwork (see Schomburg-scherff $21992,261)$. Thus, the principal focus of their work on creolization is one that stresses the place of cultural production. According to Ortiz (1993) cultural freedom and expression existed only outside of the of the plantation system, because as elaborated by Moreno Fraginals $(1984,10)$, the plantations served as a place of violent deculturation where African slaves had no opportunity to celebrate their cultural traditions. Moreover, Ortiz (1993) proposes a notion of creolization that espouses complex processes of deculturation, transculturation outside of the plantation system followed by processes of assimilation where African slaves mixed their cultural traditions with any other culture outside of the plantation that they did not find stifling or that allowed freedom of expression.

Glissant opposes Benítez Rojo and Ortiz's views that creolization could be conceptualized outside of the plantation. For him, the notion of creolization is characterized by slaves and rebels of slavery alike as found in the stories of maroons, all stand in relation to the plantation - the source and creation of Creole culture (Hofman 1994: 255, citing Glissant 1981). For Glissant (1995), creolization is an experience of diversity, a process unnoticed for a long period that is not an "uprooting, a loss of sight or suspension of being", but rather it is the means by which the newly created culture that resulted from the contacts and conflicts of cultures of "Plantation America" is given a language or way to speak for itself (269).

Glissant notes that creolization does not concern itself with the origins of its cultures. Because of this, its foundations are that of diversity that is associated with conflict and trauma. He states that the transient nature of creole culture is a sense of being 
that is not wandering or lost but rather is open to the inclusion of new elements of identity that distinguishes it from the ideologies of inclusion associated with "métissage". As discussed above, Glissant sees the process of creolization as an unpredictable and non-direct synthesis of what he call "resultants" (results) that is "something else, another way" (Glissant 1995, 269-70). In order to emphasize the boundaries of the process of creolization to the plantation, Glissant (1995) limits the process of creolization to areas such as the Caribbean, Brazil and parts of "Plantation" Middle America where different cultures thrived amidst the traumas and conflicts of slavery. Walcott's (2000) intervention helps extend Glissant's perception of seeing creolization as a process of conflicts, trauma and discordance that result in the clash of cultures to create something new. Walcott suggests that creolization allows us the means to read pain alongside the pleasure that results from the conflict of cultures and the hierarchy that is created from it. As seen in these discussions above, the main scholarship on creolization especially in the Caribbean, has focused mainly on the componential processes of creolization, its relationship with racial hierarchization and how these processes "...give legitimacy to this new dimension of human nature they constitute, the dimension of exchange and mutual exchange in a world in which apartheid and racism still rule and dominate" (Glissant 1995: 270). Other scholarships in Latin America do not read creolization within a temporal continuum that leaves for future additions or subtractions to culture as Glissant does. Like Benítez Rojo, many scholars have offered a different perspective of analyzing creolization by locating to a place in lieu of time (Collier and Flieschman 2003). The unifying ways of theorizing of creolization between scholars such as Glissant and others such as Benítez Rojo is that they all view culture as "anti-centric 
structures" that are related on the interconnectedness of other structures, which makes it an unpredictable phenomena (see Hoffman 1994: 252). While many scholars have found ways to read the "pleasure" that results from the glorification of clash in cultures that result from open structures of creolization, several others fail to read the "pain" that results from the racial hierarchization that creolization as a discourse presents. Thus, in this work I emphasize the need to read through as many national constructs of creolization as possible, especially as it pertains to musical practices.

Accordingly, the work of Vergès (2003) on creolization presents a different intervention in comparison to the scholarship I have just discussed. She asserts that creolization, at its core embodies the practice and ethics of boundless, borrowed and the acceptance of transformed encounters that must be differentiated from multiculturalism and many other forms of cultural contact (219-48). Vergès points out that the components of creolization as a discourse stands in fundamental contravention to multiculturalism because multiculturalism on one hand seeks to discursively and practically draw out how cultures relate to each other when they come into contact with the other. Creolization, on the other hand, is fundamentally about how cultures that have been chaotically forced to come into contact adapt to the sharing of a new space produced out of colonial hegemony (Puri 2004, Hall 2003).

Here, I draw on this distinction to make an argument for how Brazil through its affirmative action policies, a creolizing discourse unlike multiculturalism continues to sustain the myth of racial democracy, albeit its aims of correcting racial inequalities. That is to say that racial democracy is an ideology produced out of a discursive framework of racial hybridization that distorts actual processes of entanglement produced out of 
contact. My main concern here is that because affirmative action policies are borne out of creolized discourse (as discussed earlier in the chapter), it is a contradiction and contestation of universalized and generalized categories and structures as a feature of modernity.

\section{Part IV: Theoretical Underpinnings of Afro-Brasilidade Space and the African Diaspora}

In this section of the dissertation, I delineate the theoretical underpinnings of my conception of Afro-Brasilidade Space and how it fits into the framework of this dissertation project. The theoretical interconnections I make in this portion of this chapter is linked to the detailed examination of the specificities of Afro-Brazilian performativity and dialogic responses to statist discourse as it occurs in Afro-Brasilidade Space detailed in Chapter 4 of this dissertation. As such, in this section of the dissertation my focus is on the engagement and connections of the scholarship about the African Diaspora that greatly informs my conceptual framing of Afro-Brasilidade Space.

I borrow Brah's (1996) construct of diaspora space and Dirlik’s (1996) conception of "ancestralidade" (ancestrality) to define Afro-Brasilidade Space. I define Afro-Brasilidade Space as the articulated and expressive space of contestation where representations of blackness are challenged. It is also the conceptual space that allows Afro-Brazilians to engage enunciations of other people of African descent they perceived a relationship of kinship in the African Diaspora to contest their own experiences of racialized subjectivity.Afro-Brasilidade Space produces reggaeir@ bodies, which is the state's discursive construction of racialized bodies associated with the performativity of roots reggae as it is articulated in São Luis do Maranhão. This section of this chapter is 
comprises of three sections: In section A, I delineate the theoretical underpinnings of my conception of Afro-Brasilidade Space and how it fits into the framework of this dissertation project. In this delineation, I discuss in Section B, how Afro-Brazilians articulate citizenship through the notions of "ancestralidade" and "ethnopolitics" (Dirlik 1996; De Almeida 2004); and finally in Section C, I discuss how these notions are inscribed in the practices of other African descendant people in the space of the African Diaspora.

As I discussed in the beginning portion of this chapter, my examination of affirmative action policies is situated in its interconnectedness to Brazil's longstanding ideology and discourse of racial democracy. I have argued that affirmative action policies in Brazil are not corrective at all; instead they serve as a reactive crisis management tool that is compelled by the contradictions of the myth racial democracy. I also suggested that although affirmative action as a discourse and ideology of citizenship and belonging conceptionally carries the trope of equal rights for all, it fails to achieve equality because racial hierarchization and racism are maintained within the discursive ideology of a racial democracy. Discourses of citizenship in Brazil such as affirmative action claim to accommodate everyone and yet still deny racial hierarchy. This contradicts the structural reality that is racialized and spatialized. In its articulation, Brazilian citizenship articulates constitutionally equality for all; however, the problem rests on documentary practices, which is the translation of the constitutional laws and statutes into practice that differentially incorporate Afro-Brazilians into national peoplehood on racial grounds. The coupling of the discourses of racial democracy and affirmative action then basically serve 
as state instrumentalities of racial oppression, both through the denial of racial hierarchization and disparities.

The structural reality of Brazilian society is that of racial disparity and discrimination seen through the state's documentary of practices such as the violent policing of Afro-Brazilian performative spaces. These documentary practices do not only communicate the contradictions inherent in the hybridized discourse of racial democracy but it also speaks to the different articulations of ways of belonging and citizenship. According to Dantas (2009), Afro-Brazilian articulations of citizenship is inscribed in the validity of their African-rooted music, dance and religious performatives that has served as a unifying source of reference for their communities. In other words, Afro-Brazilians seek alternative ways of belonging that are articulated through what de Almeida (2004) terms as "ethnopolitics" (10). In other words, Afro-Brazilians are interested in defining ways of belonging that is defined by cultural mobilization of ethnicity that includes the "cultural products" tied to race (de Almeida 2004, 10). Consequentially, the focus of Afro-Brazilians in constructing space in Brazilian national peoplehood is built on the need for the recognition of cultural difference within the nation-state and the advancement of socioeconomic rights of their people that are subjugated by ethnocentric racism (ibid).

At the level of epistemology and practice, (Dirlik 1996) also defines the concept of "ancestralidade" as the way by which Afro-Brazilians define ways of belonging in Brazilian peoplehood. According to him, "ancestralidade" is espoused by the permutation of ancestral knowledge or wisdom that informs Afro-Brazilian cultural practices and spaces. It is also constituted by the reproduction and transmission of the navigation of the 
knowledges of lived racialized narratives of disparity over generation in order to continually redefine what it means to sustain a space of Afro-Brazilian citizenship through cultural production. Da Costa 2006(b) asserts that "ancestralidade" is a forceful source that interacts with the perpetuation of racial inequality and racialized identities with the goal to transform modernity and contexts of oppression. For the purposes of this project, I am interested in how "ancestralidade" engages information and knowledges of the practices of other African descendant people in the African Diaspora. Therefore, I engage the conceptions of Dirlik's (1996) and Da Costa's (2016) “ancestralidade" to make connections as to how Afro-Brazilians develop "kinship" with other black people that is as a result of perceived similar articulations of racialized subjectivities in the African Diaspora.

Firstly, I engage in brief theoretical conceptions of the African Diaspora that will define for this project, what constitutes Afro-Brazilian racialized subjectivities, their perceived connections to other people in Afro-diasporic spaces, and how that contributes to the creation and production of Afro-Brasilidade Space.

Although there has been numerous theoretical conceptions of the African Diaspora, Gilroy’s (1993) “The Black Atlantic: Modernity and Double Consciousness” and Wright's (2004) "Becoming Black: Creating Identity in the African Diaspora" have been two seminal scholarship that have defined conceptions of the African Diaspora that are instructive for this dissertation project. As such, I have chosen to focus on these two books while I connect them to other theoretical conceptions that are helpful in defining the framework of this work. I also engage in a short analysis of the limitations of each 
text in the formation of "ancestralidade" as an informative source for Afro-Brasilidade Space.

Gilroy's book, "The Black Atlantic" has been one of the most prominent theoretical text of the African Diaspora and the creations of interconnections and relationships that define being black in different spaces. In this text, Gilroy discusses how black British people connect to black American people. He employs the analytical term "Black Atlantic" in lieu of the African Diaspora to emphasize the importance of black identification that produces spaces of black imaginings, which engage black American musical practices and critical epistemology of black social culture. Gilroy in this text, is thus interested in the critiquing of two forms of nationalism as it pertains to black culture. Firstly, he critiques what he terms as "ethnic absolutism", which is Black Nationalism that defiantly refuses to accept the notion that black cultures are hybrids. Secondly, he critiques the racist British or Eurocentric nationalism that denies the place of belonging for the black British subject. He uses the engagement of the black subject and notion of modernity to analyze the ways in which black people interact with the sociocultural process of the Black Atlantic. Gilroy emphasizes that modernity defines the ways in which black people interacts in the Black Atlantic; black people categorically are part of modernity and characteristically entangled in its project.

For the framework of this dissertation, I focus on a few critiques of Gilroy's work that are informative for the notion of "ancestralidade" as an important component of Afro-Brasilidade Space. Gikandi (1996)'s critique of Gilroy's work on the African Diaspora is that the "terms of marriage between blackness and modernity", where constructions of blackness are constructed within the broader narrative of modernity but 
also perceived outside of it is problematic (2). His critique here is concerned with Gilroy's limited theorization that fails to drive the combined creation of the development of black subjectivity and the African Diaspora into the conception of modernity that is not connected to the Trans-Atlantic Slavery or colonialism. This critique hinges on the point that Afro-modernity should be conceptualized in ways that are not entangled Eurocentric processes. The notion of "ancestralidade" as defined by Dirlik (1996) is defined by the cultural transformation of ancestral knowledge or wisdom that informs Afro-Brazilian cultural practices and spaces through time. It not only informed by the transformation of knowledge that came with African descent people in the Middle Passage and chattel slavery. It also carries, transforms and engages the continuities of racism and racial subjugation as experienced by blacks in Brazil through time. Hanchard (1999)'s intervention of Afro-modernity is instructive for the conception of "ancestralidade" because it points to the cultural knowledges of Afro-Brazilian practices that are not only informed by pre-modernity or racialized narratives lived in a space outside of time. Hanchard's examination of the possibilities of Afro-modernity implies that it is not merely an attachment to Western processes, but instead it perceived as "one of the several divergent paths of modernity" (247). Hanchard suggests that

Afro-modernity represents a particular understanding of modernity and modern subjectivity among the people of African descent. At its broadest parameter, it consists of the selective incorporation of technologies, discourse, and institution in the modern West within the cultural and political practices of African-derived peoples to create a form of relatively autonomous modernity distinct from its counterparts in Western Europe and North American (ibid.).

Here, Hanchard (1999) argues that the expressions of Afro-modernity are not just engagements with the process of chattel slavery and the middle passage. He suggests 
instead that "they are responses to the age and the technological, normative and societal conditions that made the Middle Passage and racial slavery possible (247). As such, in combination with his notion of racial time he proposes that throughout the African Diaspora, Afro-modern subjects have always contested the notion that they lived in a space conceived outside of time or pre-modernity. He elaborates that African descendant persons living in modernity whose subjectivities contest disparate access to resources, knowledge and power are part of it. In response to this critique in Gilroy's text, it is important not to lose sight of the possibility that the "Black Atlantic" offers a useful framework by which the African Diaspora as an analytic offers the possibilities of imagining the cultural production of African descendant people that can be perceived outside the confined cultural boundaries of the nation-state. In keeping this possibility in mind, it helps one to conceive of an "ancestrilidade" that is not bound to only processes of slavery but also to interactions that responds to discursive ideologies of the state as well as other Afrodiasporic connections. As Helgesson (2001) puts it, the "Black Atlantic" provides the means by which one can analytically "facilitate an ethically viable articulation — one that refrains from eliding the historical burden of racism and colonialism — of the position of [the state discursive ideologies] in the processes of cultural globalization" (24).

Wright's (2004) book, "Becoming Black: Creating Identity in the African Diaspora" also reconceptualizes the African Diaspora in ways that instructive for the dialogic framework of Afro-brasilidade Space. Wright asserts that conception of the African Diaspora as a theoretical methodology that conforms it to a dialectical and dialogic thought, which is informative for $20^{\text {th }}$ century scholarship as I discuss below: 
She states, “...there is a twentieth-century intellectual tradition of African diasporic counter-discourses of Black subjectivity that is defined not by a common history or common cultural trope but by a particular theoretical methodology" (Wright 2004, 3). Wright perceives the connections of the African descendant people in the African Diaspora and their shared experiences as integral to the production of knowledge about Afrodiasporic people that allows them to examine their own positions through commonality and difference. Wright's theoretical methodology provides similar ways of examining the intricacies and complexities of black subjectivity, especially when it comes to their marginalization of Eurocentric ideologies of equality and modernity. Most importantly for the analytic of this project, Wright (2004) argues that blackness cannot be conceived and perceived in notions that are "...limited to a particular national, cultural, and linguistic border" (4).

Here, Wright's (2004) analytic of African Diaspora, which she terms as a theoretical methodology is helpful in my examination of hybridized cultures in AfroBrasilidade Space because it recognizes the importance of not defining understandings of the African Diaspora from essentialist and monolithic notions of culture and race. However, her argument that posits "blackness" as a racial category that resulted from the forced removals of West Africans to the western hemisphere ties Afro-modernity back to the transatlantic chattel slavery, as Gilroy also argues (Wright 2004, 1). This framework by Wright is not helpful in conceiving black subjectivity that results from localized hybridized process that is not necessarily tied to slavery. Her arguments here only differs from that of Gilroy's in the sense that she views "historical moments or cultural tropes for only a handful of specific communities and hence cannot function as tropes that might 
produce the African diasporic subject" (Wright 2004, 3). I generally concur with Wright's assertion here. However, I suggest that it must be incorporate black subjectivity that acknowledges hybridity that is specific to local specificities.

On that note, Du Bois' (2001) work, "The Negro" is useful by its examination of people of African descent people from different spaces of the African Diaspora. Here, Du bois reconceptualizes race that is tied to migration, which suggests that black subjectivity is conceived out of hybridity, migration, and circulation. He argues against the theoretical notions of the African Diaspora that views people of African descent outside of continental Africa as relatively less "complete" or less "whole" due to their mixed cultures and identities. Here, Du Bois work provides ways to reconceptualize space in the African-Diaspora by re-imagining black subjectivities that are produced in shared ways. Avtar Brah (1996) presents critical ways for reimagining space within the African Diaspora that informed Wright's (2004) perception of African Diaspora, and it is also very instructive for the analytic of how Afro-Brazilians in Afro-Brasilidade relate to other Afrodiasporic spaces in the African Diaspora. Brah asserts that Diasporas should be conceived as theoretical concepts, where they are "...understood in terms of historically contingent "genealogies" in the Foucauldian sense; that is, as an ensemble of investigative technologies and historicize trajectories of different diasporas, and analyze their relationality across fields of social relations, subjectivity and identity" (Brah 1996: 180). Moreover, she proposes the concept of "Diaspora", which in combination with "Dirlik's (1996) “ancestralidade" is very useful in my analytic of Afro-Brasilidade Space. Brah defines Diaspora Space as a conceptual category that is: 
Inhabited not only by those who have migrated and their descendants, but equally by those who are constructed and represented as indigenous. In other word, the concept of diaspora space (as opposed to that of diaspora) includes the entanglement, the intertwining of the genealogies of dispersion with those of "staying put". The diaspora space is the site where the native is as much a diasporan as the diaspora is a native (Brah 1996; 209).

Brah's notion of Diaspora Space is helpful in my conceptualizing of the AfroBrasilidade because it implies that Afro-Brasilidade Space, as an Afrodiasporic space, it is constructed by the same discourses that impact the African Diaspora. Consequently, although Afro-Brasilidade Space and other Afrodiasporic spaces in the African Diaspora do not occupy the same physical space, they are all conceptualized under the same ideological space, which in turn creates the foundations of the production of knowledge and epistemologies about the African Diaspora. In regard to the study of the African Diaspora, albeit it being important, Brah (1996) does not see the value in simply identifying the specificities of any particular Afrodiasporic experience; neither does she find value in simply historicizing the experiences of any particular Afrodiasporic space. Instead, Brah insists on the imperativeness of the conceptualization of the African Diaspora Space as an analytic that calls for "the historically variable forms of relationality within and between diasporas" (Brah 1996, 183). This analytic then leaves room for one to address the localized and specified experiences and contestations in AfroBrasilidade Space in relation to other Afrodiasporic sites that challenges statist discursive ideologies of race and citizenship.

I have now addressed how Afro-Brasilidade Space is conceptualized using the analytics of "ancestralidade" and African Diaspora Space. I now turn to how I will 
address the question of localized specificities of a place within the African Diaspora that speaks to the Purian (2004) framework I mentioned earlier in this chapter. In order not to lose the specificity of São Luis do Maranhão in an analytic that is founded in the conception of the African Diaspora Space, I employ Glissant's views that all cultural formations are creolized. However, as I have discussed in detail in the Section II of this chapter, I do make use of the term creolization in its credulous generalized form such that I lose the specificity of the cultural mixture that happens in Afro-Brasilidade Space.

According to Glissant (1989) the significance of creolization is not "the glorification of the composite nature of people; indeed, no people has been spared the cross-cultural process. The idea of creolization demonstrates that henceforth it is no longer valid to glorify "unique" origins that the race safeguards and prolongs" (140). By employing this view of cultural mixture, creolization intersects well with Foucauldian notion of genealogy in lieu of history. I employ the term creolization in order to dissect the complex nature of cultures and to identify the political forces in statist discourse that constrains moments of cultural hybridization. In the context of São Luis, creolization is instructive for this project (instead of mestizaje as I have discussed in detail above) because it focuses on the further mixings of a Caribbean musical and dance form in an already hybridized space. It also opens up the space for me to discuss contemporary cultural practices that are associated with other Afrodiasporic spaces that are not conventionally "Brazilian” or "Afro-Brazilian" in their formations. Most significantly, I believe creolization, as an analytic is useful in this context as it unsettles the ideological views about traditional popular culture in Brazil, its reproduction and preservation especially as it relates to the concept of "ancestralidade". Moreover, the use of 
creolization allows me to discuss and trace what constitutes the mixtures of performances that happens in reggaeir@ spaces and its root origins. These performances then can be seen as part of a protracted and complex process of cultural exchange and fusion that is responding to different forces in cultural politics.

\section{METHODOLOGY:}

\section{Research Questions:}

Research Question \#1: How do Reggaeir@ embodied performative musical practices reproduce and contest the discourses of citizenship in São Luis do Maranhão, Brazil? I addressed these questions through participant observation, focus groups, semistructured interviews and the consultation of archival documents to assess the formal and informal ways in which reggaeir@s performative spaces are discursively included and excluded in in the city.

Research Question \#2: What roles do Reggaeir@ performative spaces play in these processes?

I addressed this question using exploratory interviews, place perception interviews and mobile focus groups.

Research Question \#3: How are the quotidian realities of Reggaeir@s rendered visible or invisible under the discursive changes of affirmative action policies?

I addressed this question by analyzing locally accessible primary sources (newspapers, institutional reports, policy documents, and public court reports), local census database and legislations (municipal legislation on leisure, entertainment and culture). 


\section{Research Design and Methodology:}

I conducted the entire fieldwork of this dissertation project in São Luis do Maranhão, Brazil. I began the preliminary exploratory portion of my research from December 2010 and concluded it in the following summer from May 2011 until August 2011. I returned to São Luis in December 2015 and stayed in the field until I finished collecting all of my data in September 2016. A substantial portion of this dissertation research methodology employs ethnography (participant observation, interviews and focus groups) and archival and documentary research to investigate the performative spaces of reggaeir@s and their musical practices. These methods specifically targeted particular research questions that examine how reggaeir@ spaces are policed under Brazil's documentary practices even after the institution affirmative action practices.

\section{Performance Ethnography: Navigating the Reggaeir@ Space as a Young Black Woman}

In addition to my use of traditional ethnographic methods, I also employ the methodology of performance ethnography. I combine my use of performance ethnography with what I term as "situations" as discussed the ethnographic portion of this dissertation (see chapter 5). To date, there are very few ethnographic works about reggaeir@ musical practices both in and outside of Brazil. The choice to use ethnography, especially performance ethnography was very intentional. I planned to use this project, based on its methodology to address the gap in ethnographic scholarship that focuses on a very personalized experience of roots reggae culture in this region of Brazil. I heavily emphasize that my work as performance ethnography, especially because I 
became friends with the population I studied, I danced agarradinho in the dancehalls and in the nightclub spaces together with the men and women who welcomed me into their world of reggaeir@ismo. Most significantly, because I lived with the study population, I saw their efforts to help me understand the reggaeir@ lifestyle as more of a collaborative effort. Performance ethnography focuses on the importance of engagement of the researcher with the communities of study as opposed to the "fly on the wall" or “objective" observer view (Madison 2005, Conquergood 2006).

According to performance ethnographers such as D. Soyini Madison (2006), E. Patrick Johnson $(2003,2006)$ and D. Conquergood (2006), performance theory is essential to the study of music and dance cultures in particular because it posits the body as the focus in the conduction of ethnographic research. Consequently, my theorizing of reggaeir@ performative spaces in conjunction with my ethnographic work on these spaces becomes an embodied and experienced practice, where my "doing" of ethnography is " "with" not "of" a group of people" (Fabian 1990, 43 cited in Conquergood 1992: emphasis on the original).

I mentioned earlier that not only am I a trained dancer but I have also been a longterm aficionada of Afrodiasporic music and dance. I have always been familiar with the various dance styles of the Caribbean region, especially dances "reggae" music its evolution over the years. However, experiencing agarradinho dancing to roots reggae music in very specific in São Luis, was an experience far from what I have been trained or engaged in, in any space for that matter. Performance ethnography gave me an opportunity to seek out and read fliers and posters about upcoming events and dance nights with eagerness as if I was a local because I showed up in these spaces to not only 
observe but to engage with the communities I researched. Without having to think too deeply about my research questions, I was able to engage in mundane discussions about the performance of a particular DJ the night prior or which neighborhoods had the best dance nights over lunch with researchers because we often shared the same experience. I listened, complained and fought many insomniac nights to the sounds of roots reggae music pumping out of neighborhood radiolas late at night. Hence, performance ethnography encompasses the very tool that helps me travel into worlds of music in these spaces not only as an oratory performance but also to the embodiment of dance as well as the sensitivities of interpreting and translating the music practices as part of everyday life.. Furthermore, this research design then allowed for me to connect what it means to be a reggaeir@ ethnographically with the discourse surrounding its performance.

Researching Reggaeir@ culture as a musical and dance practice "autoethnographically" requires me to be aware and conscious of my own body and to critically interrogate it in the spaces of performances as I inserted myself into reggaeir@ spaces. This meant that I had to listen, interact, observe, and communicate using the same analytical eye that I use in this research such that I cannot hide behind the "objectivity" of my methodology. It is then important that I address how my participation in performances in my research affects my ethnography. It is also important that I make the reader aware that my insertion of myself into my work immensely impacts the way I approach this research and how I theorize it. The lens that I use to analyze this research and the conclusions I draw from it are based on who I am as a person, my positionality as a trained scholar etc. It is important to foreground that fact that these factors impacted the interactions I had with the communities I studied in this project. 
As I mentioned earlier in the introductory portion of this work, my intense interest in the interdisciplinary study of legal policies in Latin America impacted my decision to do fieldwork in Brazil. The decision to study the subject matter of performance and musical practices within the Afro-Brazilian community is heavily impacted by interest as a black trained dancer; and the theoretical framework of diaspora and performance rooted in in my interest in citizenship and Performance analytics are informed by experiences as a person of African descent living in the Diaspora.

In light of this, it is important for me to underscore my blackness, my complexion as a deeply complected woman, my Americanness, my gender as woman, my age as young person in her 30 s, my sexuality as heterosexual person and my foreign-accented Portuguese speaking in a research space of predominantly impoverished black population (and other times middle class spaces) as a significant part of how I moved through these spaces of research, in addition to how I think about and interacted with people in the research space. I found that black researchers were more willing to talk to me about music, and especially "black" music and dance in general. I also observed that both black men and women were more willing to discuss the cultural politics of reggaeir@s in São Luis with outsiders, although this is complicated by the fact that I was both perceived as an outsider and insider at the same time because of how blackness is interpreted in Brazil. In this case, when I had casual conversations in dance spaces, most people were very forthcoming with information even after they found out I was a foreigner who speaks Portuguese. Although the conversation often drifted into requests for me to interpret the English lyrics for them, the subject matter was consistently directed to identifying themes of "black struggle and liberation" in the songs as a conversation unifier between the 
interlocutor and I as the researcher. As a racialized subject, I found myself both understood as "irma" (sister) in the diasporic sense and at the same time an outsider because I am American and I am automatically assigned a higher socioeconomic class in these interactions. In these conversations there is always an intense fascination with my Americaness because most people associated Americanness with whiteness as often portrayed on Brazilian media outlets.

My deep dark skin meant that many read me as Baiana (from Salvador da Bahia) at first and then Angolana or Mozambicana after I spoke because of my accent and then translated my features as more Afrocentric. As a young black woman, I found access to both black women and young black Ludovicenses to be relatively easy — being a foreigner or black woman seemed less of an issue within these communities. Moreover being an American gained me access with poor communities through the perceptions of researchers wanting to associate with a person "of wealth" or "of means". Contrastingly, with the upper middle class researches who were white passing or white, I was often given the access through the perception of "you more of a co-equal" or "rich foreign black" treatment. With upper middle class researchers, who were often white or whitepassing, the conversations were often preceded with feeble attempts to speak English albeit it in broken sentences or their use of a few English words in the interviews in attempts to prove their knowledge of it. All of these observations are based on my own opinions in accordance the themes of conversations, on bodily language or on certain conversational references. 




\section{Photo 1: Picture of Author in Roots Bar, Centro Historico (Picture taken by Ribamar Nascimento)}

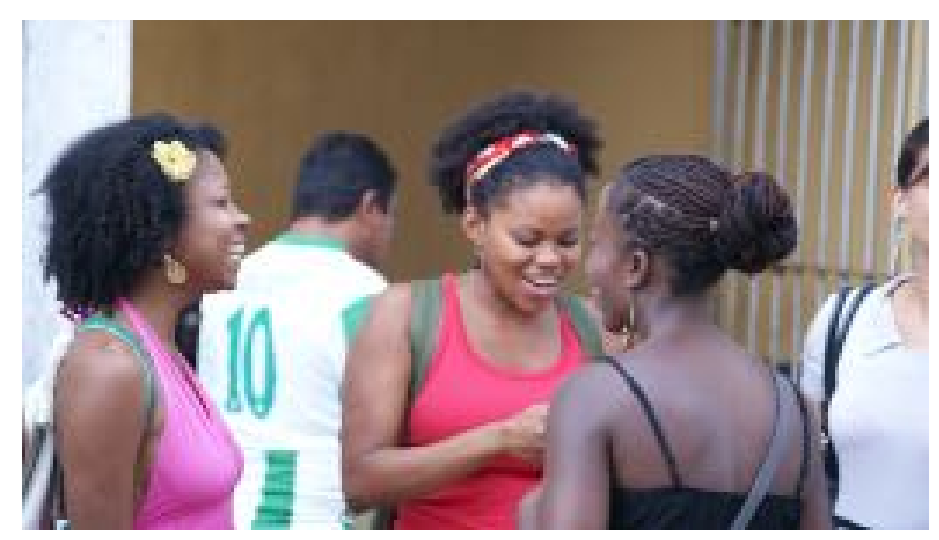

\section{Photo 2: Picture of Author in Centro Historico (Picture taken by Ribamar Nascimento)}

Performance ethnography provides ways in which to deeply analyze musical and practices, especially the ways in which musical and dance practices work to dissolve the mind/body hierarchy (Conquergood 2006). Moreover, as stated by Conquergood (2006), performance ethnography gives the researcher the liberty to engage in an ethnography that is based on "listening and speaking, instead of merely observing, [thus] challenging the visual bias" of western epistemology (355). He also suggests that the auditory experience of ethnography allows the researcher to analyze the "privilege sound [in the] 
temporal process, [its] proximity, [and its] incorporation" as opposed to the representations and symbolisms of sight that is imbricated in "detachment, distance, and withdrawal from intimacy" (ibid.). Performance ethnography draws on the intimacy that is captured in the combination of seeing, moving and especially hearing rhythms and sounds, as well as "being present" in the moments enhanced by the "situations". In a nutshell, fieldwork as captured in performance ethnography requires the collaborative and co-performance of the researcher, the space and others engaging in embodied rhythms (Denzin 2003, Conquergood 1992, 2006).

I employed these methods in a 5-phase research process during a period of ten months in the two main parts of the city of São Luis do Maranhão — the older historical city, which consists of the six clubs and dance spaces in Centro Historica (Reviver) and the surrounding neighborhoods of Camboa/Liberdade, Fátima and João Paulo, and the newer city, which consist of upper and upper middle class neighborhoods, Ponta D'Areia and the so-called tourist-friendly lodging areas along Avenida Litorânea (See Map 1below). Other major research sites constituted various archives listed in Table A 


\section{Map 1: Research sites featuring the city of São Luis and Metropolitan Areas}

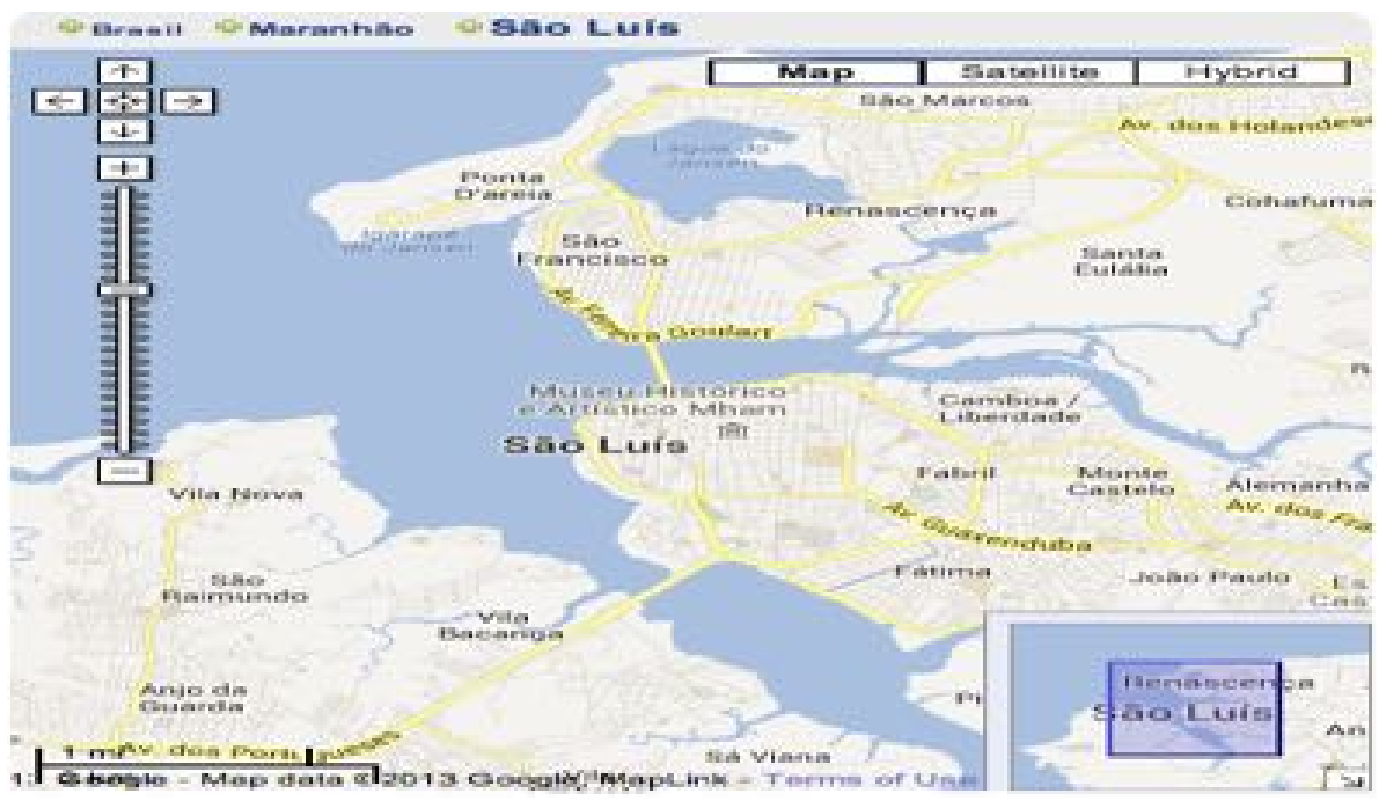

Table A: Major Research Sites and Archives

\begin{tabular}{|l|l|l|l|}
\hline & Group 1: Centro + Periferias & $\begin{array}{l}\text { Group 2: Avenida Litorânea + } \\
\text { Novo Bairros }\end{array}$ & Group 3: Archives \\
\hline $\begin{array}{l}\text { Name of Space } \\
\text { (location) }\end{array}$ & $\begin{array}{l}\text { Roots Bar Club (Reviver) } \\
\text { Bar do Nelson (Reviver) } \\
\text { Rotatorio Roots }\end{array}$ & $\begin{array}{l}\text { Bar do Nelson (Litorânea) } \\
\text { Créole Bar (Ponto D'Areia) }\end{array}$ & $\begin{array}{l}\text { Arquivo Público do } \\
\text { Estado do Maranhão } \\
\text { Biblioteca Pública da } \\
\text { Cidade do São Luis }\end{array}$ \\
\hline $\begin{array}{l}\text { Name of Space } \\
\text { (location) }\end{array}$ & $\begin{array}{l}\text { Porto da Gabi (Centro) } \\
\text { Novo Quilombo (Liberdade) } \\
\text { Chama Maré }\end{array}$ & Coalho (Litoranea & $\begin{array}{l}\text { Arquivo Distrital de } \\
\text { Dados Processos } \\
\text { Judicias e } \\
\text { Processuais }\end{array}$ \\
\hline
\end{tabular}




\section{A. Traditional Ethnography and Performative Ethnography}

During Phase I of my research, I used participant observation in order to become familiar with the lives, spaces and musicology of reggaeir@s around the city (Corbetta 2003, Bernard 2006). I also used participant observation to be conversant with reggaeir@ dancehall spaces, the dances, and the interaction between people in these spaces.

My key informant and locally-based research associate, José Ribamar Pereira do Nascimento, whom I have been working with since 2010 through my pilot research, is a gatekeeper to the reggaeir@ community; he assisted me to gain access to the social and performance space of reggaeir@s. He was also the key point of connections with the major disc jockeys (DJs) and club owners, music collectors and radiola owners who manage these spaces. It was important to engage in this step of the research to gain trust of the research population as an outsider and also to account for the power dynamics between the researcher-researched relationships that is prevalent in fieldwork (Crang and Cook 2007; Emerson et al. 1995; Wolf 1996).

I used my daily field notes, often taken on my cell-phone to take notes during my interactions with people and places in the various clubs and dancehall spaces in the city (Bernard 2006). In order to produce a "thick description" of the dancehall space, routines and sociocultural interactions of reggaeir@s, during Phase II of the research, I conducted informal exploratory interviews in the clubs and dancehalls to get an insight into the construction of reggaeir@ identity (Geertz 1973). I recruited my participants (n =5) from each dance space through snowball sampling—by interviewing reggaeir@ friends of my gatekeeper. This step gave me the opportunity to be contextually embedded 
in reggaeir@ spaces and to get an insider perspective of the city and its music traditions. It also allowed me to gain trust and build rapport with participants.

During Phase III of the research, I utilized the ethnographic method of focus groups to generate themes and further directions to target my first and second research questions. I employed the help of the six male and two female DJs identified during my pilot research to recruit participants for two focus groups. The DJs of the radiolas Estrela do Som, Super Itamaraty, Diamente Negro, Radiola Reggae, Leal Som, and Rádio Zion ${ }^{7}$ respectively, to help me recruit 20 reggaeir@s who are knowledgeable about the specific dance spaces using a quota sampling design (see Table B).

The first focus group consisted of four identified DJs (two males and two females) and four self-identified reggaeir@s (two females and two males) recruited from dance space parties in Centro and the surrounding periferias. The second focus group consisted of the other four DJs and another four self-identified reggaeir@s (two females and two males) recruited from dance space parties in reggaeir@ clubs in the newer, upper and middle class bairros $^{8}$ of the city. According to Guest et al. (2006), a minimum of 12 participants in focus groups are a reasonable benchmark for capturing the views of two or more social groups in a given dimension in quota sampling. I chose eight participants for each focus group for manageability and efficient theme development.

Furthermore, because my previous pilot research had revealed that very few people who identified as reggaeir@s frequent dancehall spaces in both Centro and the surrounding neighborhoods in the upper and middle class areas, I recruited more

\footnotetext{
7 Named sound systems that identifies particular reggaeir@ party organizers and their DJs

8 Neighborhoods around the city
} 
interviewees from the periferias than I did in other spaces. As such, the quota sampling selection for the focus group in both spaces ensured that reggaeir@s from both research sites were well represented to generate themes and discussions for my first and second research questions respectively. I used the themes developed in the focus groups to generate questions for semi-structured interviews in the next phase of the proposed research.

\section{Table B. Quota Sampling Matrix}

\begin{tabular}{|l|l|l|}
\hline & $\begin{array}{l}\text { Reggaeir@ Identity } \\
\text { Construction }\end{array}$ & Reggaeir@ Space and Place \\
\hline $\begin{array}{l}\text { Focus Group 1: Centro and Periferias } \\
\text { group }+D J_{S}\end{array}$ & 8 & 8 \\
\hline $\begin{array}{l}\text { Focus Group 2: Upper-class Bairros and } \\
\text { Tourist space group + DJs }\end{array}$ & 8 & 8 \\
\hline
\end{tabular}

In Phase IV, I used the themes and directions generated from the focus groups to conduct ethnographic semi-structured interviews. With the help of my locally based research associate and DJs, I used purposive snowball sampling to recruit an additional 14 reggaeir@s to add on to the participants of the focus groups to participate in the semistructured interviews $(\mathrm{n}=30)$. The semi-structured interview questions following the themes developed in the focus groups also targeted research questions 1 and 2. According to Morse (1994) and Bernard (2006) approximately 30 to 50 interviews are standard benchmarks for participants in ethnographic fieldwork in order to achieve data saturation. This phase was important to gain the participants' input to shape and refine my research strategy. 


\section{Ethnographic Data Analysis}

In order to ensure that the data I had collected from the field was formularized in a continuous process (Corbetta 2003), I engaged in a routine that intersected my observation with my analysis. During each week of my data collection, I digitized and coded my field notes using NVivo10 qualitative data analysis software. Using "analytic note" and recurrent memo-ing, I categorized my field notes into data of theoretical interest, topics of additional inquiry and emergent research themes (Bernard 2006; Corbin and Strauss 2008). I drew on the various parts of my ethnography-semi-structured interviews, focus groups, informal conversations and visual observations to contextualize and interrogate my research questions in order to engage in "thick description" (Geertz 1973) of my research.

I transcribed and translated sets of interviews as I conducted them, and I used grounded-theory text analysis and open coding using NVivo10 qualitative data analysis software to identify key concepts and categories (Corbin and Strauss 2008). I then coded the interviews and field notes along the themes developed in the focus groups and my research questions initially (Ryan and Bernard 2003). As I expected, the coding themes evolved with the progress of my research (Bernard 2006).

\section{Archival and Documentary Research}

During Phase $\mathbf{V}$ of my research, I engaged in archival and documentary research to complement my ethnographic work. The archival work mainly targeted research question three, although it also deepened the contextualization of my research questions one and two. I conducted multi-sited archival research to locate newspapers, institutional reports, policy documents, census reports and crime statistics reports that documented the 
genealogy of reggaeir@ spaces in the city. My archival research took place at the following archival collections that houses relevant legal and policy documents, and journals: Arquiva Público do Estado do Maranhão (The Public Archives for the State of Maranhão) located in São Luis do Maranhão, Biblioteca Pública do São Luis do Maranhão (The City of São Luis do Maranhão's public library), Arquivo Distrital de Dados Processos Judicias e Processuais (The Local Archives for Judicial and Court Cases). All of these archives are open to the general public with the exception of Arquivo Distrital de Dados Processos Judicias e Processuais. For this archive, I worked local federal judge, who helped me gain access.

My objective with this phase of the research was to analyze informal but especially formal ways that detail the various ways in which the law, in the form of legislations and policies operate as a surveillance to police reggaeir@ spaces. I also supplemented my archival work with contemporary document research by reviewing eight daily newspapers, current magazines and blogs such as, O imparcial, Jornal Pequeno, Jornal O Quarto Poder, Jornal Atos e Fatos, Gente e Negocios, A voz dos Municípios, Jornal Cazumba, all of which publicize happenings and events surrounding reggaeir@ spaces. Through the help some friends who had saved clippings of old roots reggae newsletter articles and magazines, I had access to three reggaeir@ newsletters that had been out of print since the 1980s, namely, Jornal Itaqui-Bacanga, O Tambor and 
Mass Regueira. ${ }^{9}$ This step helped me to understand the dominant, on-the-ground narratives about reggaeir@ culture that are projected into popular culture media.

\section{Archival and Documentary Data Analysis:}

Following the archival and documentary research, I deductively analyzed the information obtained using NVivo10 qualitative data analysis software. I searched for content relevant to etic categories that capture research question number three. I analyzed the content for quotes, images, expressions that elicit understandings on visibility, marginalization, policing, surveillance and identity construction and censorship as it pertains to reggaeir@ identity and spaces, and I categorized them into etic categories (Ryan and Bernard 2003). I compared the documents by different authors, actors, agencies and archives for differences and similarities to draw out intricate understanding of reggaeir@ spaces (Glaser and Strauss 1967). In analyzing the contemporary and archival documents, I used critical discourse analysis to assess how power relations between reggaeir@s and the police and particular representations of reggaeir@ spaces in the media were used to create imagining reggaeir@s and their spaces in general.

In this chapter, I have laid out what I consider to be a guiding analytical framework through which I attempt to analyze the reggaeir@ performative space, music and dance practices in São Luis do Maranhão. I have also discussed in detail my research design, methodology and its analysis. In the next chapter, I engage the reader in a genealogy of reggaeir@ musical practices and culture as well as the contextualizing of

\footnotetext{
${ }^{9}$ Massa Regueira (with "regueira" being a variant spelling "reggaeira") was an old newletter that broadcasted roots reggae news and happenings all over the state of Maranhão.
} 
the sociocultural and socioeconomic historiographies of the city of São Luis do Maranhão in which the reggaeir@ performative space is embedded. 


\section{Chapter 2, “A Viagem”: Historicizing Roots Reggae and the Reggaeir@ Space Contextualizing the Reggaeir@ Space, the Island City of São Luis do Maranhão}

In the fall of 2010, I embarked on a journey to combine my newly found passion for social science research with my fascination with the recent enactments of legal policies for the correction of racial equality in Latin America. Consequently, I began studying the ways in which discursive articulations of citizenship are being translated into state documentary practices in the region. My interests led me to the Northeastern island city of São Luis do Maranhão, Brazil, where I began studying the clash between the military police and the predominantly poor black participants of the reggae dancehalls, nightclubs, neighborhood parties and citywide concerts spaces around the island. This doctoral work is the culmination of over nine years of research into the dance and musical practices of reggaeir@s (participants of roots reggae musical culture) on the island of São Luis do Maranhão.

In order to give the reader a "thick description" of the research space of this dissertation, it is necessary to contextualize the Brazilian city of São Luis do Maranhão historically, politically, geographically, culturally, economically and socially (Bernard 2006). Hence in this chapter of the dissertation, I descriptively engage in a detailed genealogy ${ }^{10}$ of the various influential aspects of the city that contributes to the complex relationships that make up its popular culture, especially the music and dance performance surrounding roots reggae.

${ }^{10}$ In this work, I use genealogy in the Foucauldian sense in lieu of a dominative account of history. Foucault (1977), geneology stands in contrast to history in that is lends itself to the space for the conditional and divergent accounts that "...rejects the metahistorical deployment of ideal significations and indefinite teleogies. It opposes the sear for "origins"'” (140). 


\section{Jamaica Brasileira me Encanta: My first encounters with São Luis do Maranhão and its Roots Reggae music Scene}

I initially found out about the reggae scene in São Luis do Maranhão after attending COPENE_Congresso Brasiliero de Pesquisadores/as Negros/as, a conference for Afro-Brazilian researchers in the Summer of 2010 in Rio de Janeiro. A group of my Afro-Maranhese researcher friends invited me to the city center in Lapa for a "call and response" Tambor de Crioula roda ${ }^{11}$ session they were performing in. Naturally as a trained dancer, I joined in the circle and quickly picked up its intense and invigorating steps. It similarity to samba da roda of Salvador da Bahia prompted me to ask my friends several questions in between sessions. I asked questions about black music and dance culture of Maranhão and how that compared to Bahia’s black culture. My good friend, Rosiane Cardoso defensively responded with this sentiment,

"Oh so with these questions, you obviously think Salvador is the only Brazilian city with black people and culture! We Afro-Maranheses exist and we "reign" in the arena of reggae in Brazil. Come to Jamaica Brasileira - Brazilian Jamaica. Come see how we do it on the island of love and agarradinho ${ }^{12}$ !"

For the rest of the night, the group proceeded to share their versions of how São Luis has long been hailed as the roots reggae capital of Brazil for decades, hence the name, Jamaica Brasileira (Brazilian Jamaica). They spoke about how roots reggae spaces serve as their own safe spaces of leisure, how dancing agarradinho to roots reggae is a black innovation unique to São Luis in Brazil, and how black organizing around roots

\footnotetext{
11 Tambor de Crioula is an Afro-Maranhese "call and response" drum and dance circle where an all female dancers group adorned in elaborate brightly colored and flared skirts respond in song and dance to the calls of a group of drum percussionists.

12 Agarrado or agarradinho refers to the "lover's rock" embraced ballroom style of dancing to roots reggae in São Luis do Maranhão
} 
reggae is part of their contribution and involvement in the Movimento Negro $^{13}$ (the black social movement). For the most part, my fascinations with their stories about an AfroBrazilian ballroom dance style combined with roots reggae music, a Caribbean art form, on a Brazilian nordestino ${ }^{14}$ island city, brought me to São Luis do Maranhão for the first time in December 2010.

The journey to this island city of São Luis itself was a feat and it later opened my eyes as to why this setting is scantily researched by academics outside of Maranhão. For the most part, São Luis remains uniquely free of the tourist traffic that other Brazilian cities such as Salvador da Bahia and Rio de Janeiro receive. There are no direct flights from most American or European cities to São Luis and so most of the international connecting flights to the island are routed through São Paulo, approximately 2000 miles in the far south of the country.

Upon my first visit, São Luis looked to me like a crossbreed between a rural Amazonian town and a tropical rundown colonial paradise where roots reggae is played out loud on every corner bar, restaurant, taxi stop, street vendor stalls, and local retail grocery kiosks. In fact, describing the permeation of the music throughout the very fabric of the city fleeces it of its essence-reggae here is best experienced than described. Outside of the historic center (as described below), the majority of the city's one million inhabitants that are black and indigenous people call the periferias located to the east and

\footnotetext{
13 The generic name given to the various Afro-Brazilian social movement that occurred in the $20^{\text {th }}$-century Brazil, post World War II onwards.

14 The Northeast of Brazil is the designated socio-geographic region that comprises of 9 states: Maranhão, Piaui, Ceará, Rio Grange do Norte, Paraiba, Pernambuco, Alagoas, Sergipe and Bahia (as well as the archipelago Fernando do Noronha). This northeastern region of Brazil, amongst the other five regions has been historically, politically has been known for its distinct culture (particularly black culture) and natural resources.
} 
the south of the island home. Unlike the favelas that dangle over the hillsides in Rio de Janeiro and Salvador da Bahia, these sprawling shantytowns in this coastal city are ground level infrastructures (see photo 5).

Right outside of the city center is a four-lane highway and connecting bridges that conceals the long stretch of beach that kisses the heavily oil tanker polluted Atlantic Ocean (see photo 3 and 4). The connecting bridge (see photos leads to the western and northern part of the city, where the middle and upper class predominantly white population live. The single unifier of São Luis population is its attachment to reggae music. This strong affinity to roots reggae music begs of the question as to how the Jamaican sounds arrived on this Brazilian island city and what role the music plays in this setting.

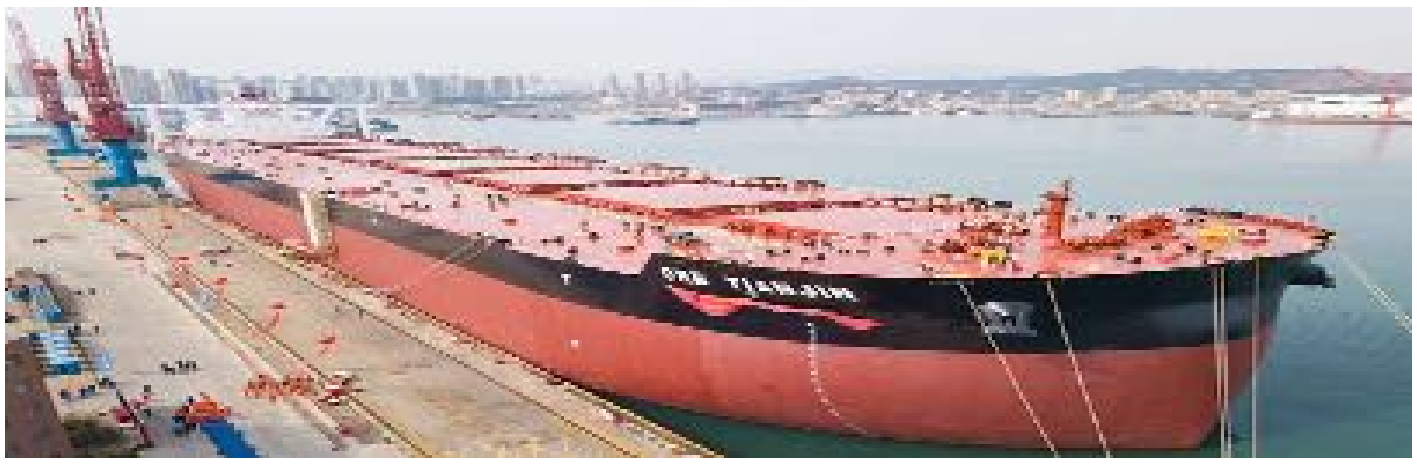

Photo 3: Picture of Oil tanker ships on the ports of São Luis






\section{Photo 4: Picture of Oil tanker ships on the ports of São Luis}

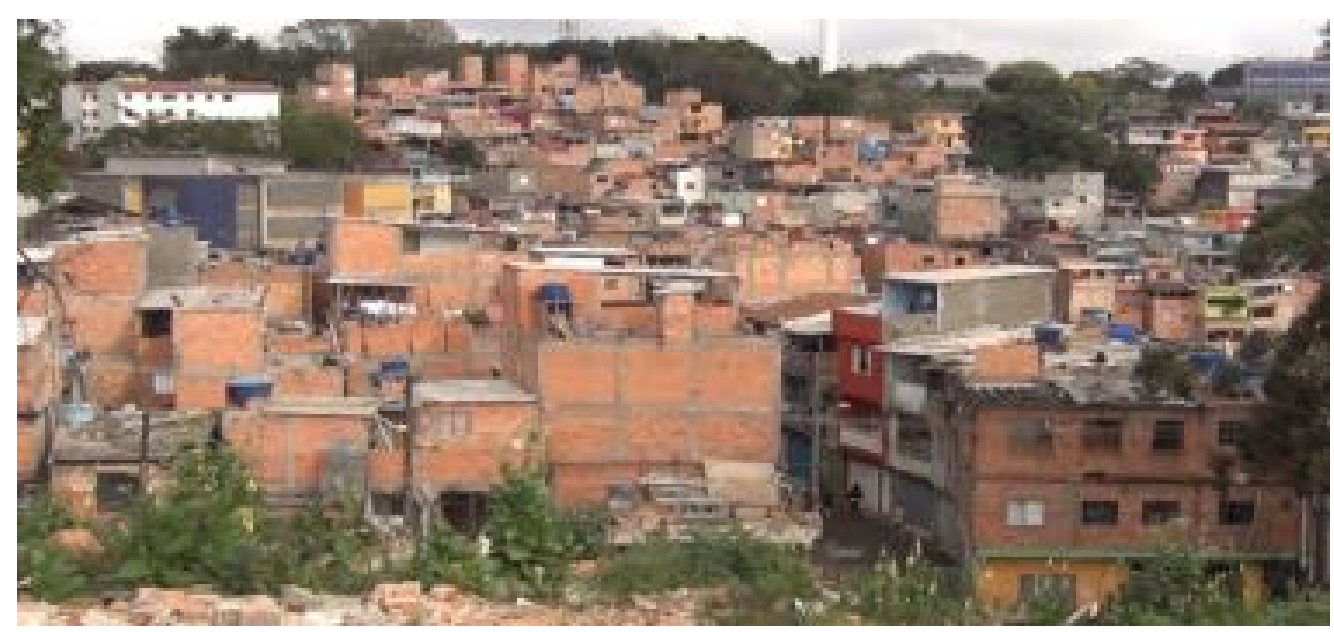

Photo 5: Picture of Sprawling Shantytowns in São Luis

Various researches on reggae music outside of Jamaica and the Caribbean tend to focus on subcultures that mimic the dominant local Jamaican cultural and political enunciated forms (Chang and Chen 1998, SA King and BT Bays 2002). However, in order to understand the reggae scene in São Luis and the performative spaces of reggaeir@s on the island, the reader needs to abandon the notions about the Jamaican reggae scene, Rastafarianism and all other debates about roots reggae music as it pertains to the Caribbean in particular. I make this assertion particularly because of the ways in which reggae interacts with the political practices of São Luis, its local economy and the notion of reggaeir@ismo as I will discuss later on in this dissertation. 
Outside of the state of Maranhão, reggae music remains a largely unpopular cultural form in Brazil. It is worth noting that in 1986, Salvador's Olodum ${ }^{15}$ started producing a reggae fusion form that lasted briefly only to be outdone by $a x e^{16}$ in succeeding decades (Crook 1993). Even so, this form of reggae was considerably rooted in samba to the point that one would hardly call it roots reggae. It is then safe to say that the presence of a reggae scene in Brazil as noted in Salvador da Bahia, Rio de Janeiro and São Paulo in recent decades have been majorly underground. This is in contrast with the music and dance reggae scene in São Luis do Maranhão. Additionally, the influence that reggae has on São Luis's electoral and cultural politics is unparalleled in Brazil as I highlight later in this dissertation. In order to understand the purpose and functions of roots reggae musical practices on the island, it is important to historicize the island, its popular music performance-scapes. In the next section of this chapter, I engage the reader in a brief historicization and contextualization of São Luis that will situate the arguments and theorizations I make in the other chapters of this dissertation.

\section{Historical and Geopolitical Contextualization:}

São Luis do Maranhão is the capital city of the Northeastern Brazilian state of Maranhão. The city is estimated to be about 348.62 cubic miles. It is situated in the midway between the Amazonian gateway city of Belém and Northeastern metropolitan

\footnotetext{
${ }^{15}$ One of the major bloco-afro from Salvador da Bahia's carnival that came out of the bloco-afro Ilê Aiyê in the 1970s.

${ }^{16}$ This is one of the popular carnival music genre in Salvador da Bahia that fuses different Afro-Caribbean genres such as marcha, pop and calypso as well as Brazilian music forms such as frevo, forró and carixada.
} 
city of Fortaleza. Geographically, it is located on the Bay of São Marcos, which is an extension of the Atlantic Ocean that forms the cluster of municipal islands, namely, São José de Ribamar, Paço de Lumiar e Raposa, with the island of São Luis being the largest of the four islands (See Map B below).

Map B: Map of São Luis showing its geographical location in relation to the Caribbean, the Atlantic Ocean and other Latin American nations

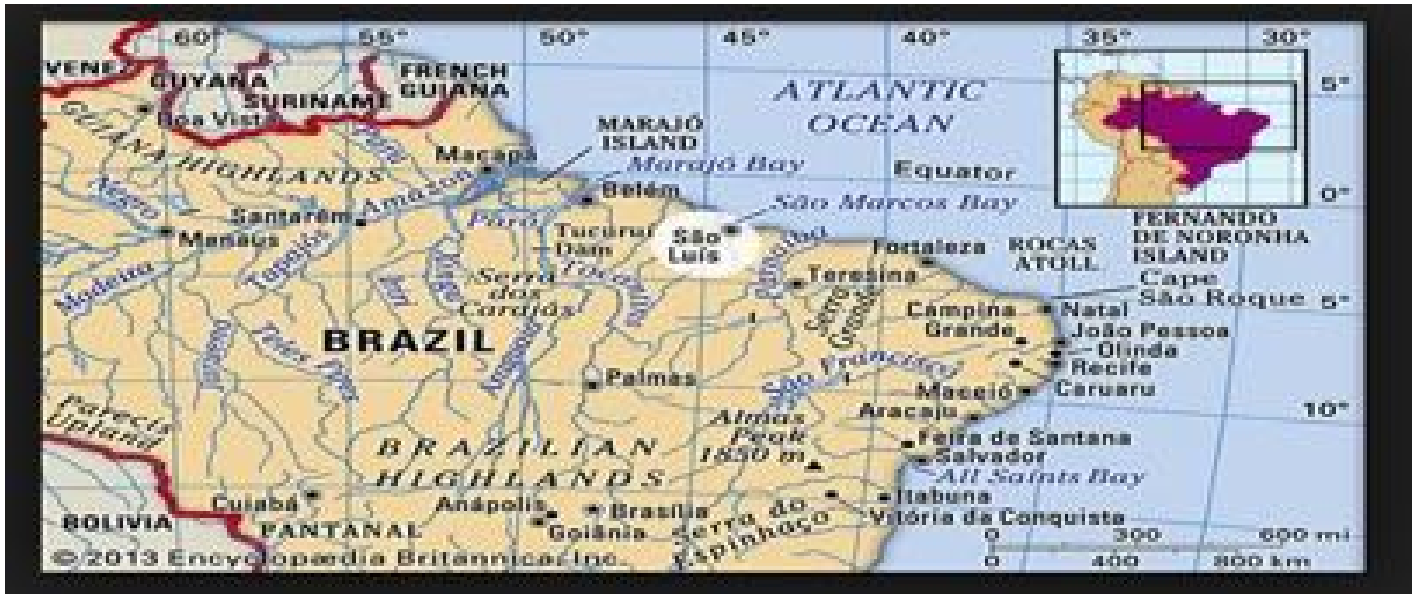

As the largest city in the state, São Luis has a population of approximately 1.6 million inhabitants, with the majority of its population living in its metropolitan areas of the city (Instituto Brasileiro de Geografia e Estatistica (IBGE, 2016). Of these inhabitants, about $40 \%$ are men and $60 \%$ are women. The majority of São Luis’ population lives in the urban areas - according to IBGE, about $90 \%$ of its population lives in the urban areas and the remaining 10\% lives in the interior (rural interior areas). Historically, it is one of the oldest cities in Brazil, founded in 1612 by Daniel Touché de la Ravardière, a French naval officer (Goulart, 1975). As the only Brazilian city that was founded by the French instead of the Portuguese, it was named in honor of the then French King Louis XIII. Due to São Luis's proximity to Africa, Europe and the 
Caribbean, it was a strategic slave port for European slave traders. The French colonized and controlled the city from 1641 to 1644, and then the Dutch army led by Maurice of Nassau took over after conquering it (ibid).

Later in 1755, alongside the Northeastern city of Belém, the Portuguese took over the city, renaming it as the capital of the then province of Maranhão and Grão-Pará in the Portuguese colonies (Hallewell 1985). The administrative joining of the provinces resulted in a mixture of inhabitants that included African Slaves, indigenous natives, European settlers and bandeirantes (slave hunters). According to the $\mathrm{IGBE}^{17}$ census at the turn of the eighteenth century, the population of Maranhão was about 4,891,699, of which 315,960 were considered black, 23,243 were considered pardo (brown). The population at this time was also made up of 31,722 indigenous inhabitants and 28,573 mulattoes (Goulart 1975, 155 as cited in Silva 1995).

In 1755, following the European industrial revolution, São Luis' economic development expanded when it began to export agricultural products such rice, tobacco, sugarcane, cacao and leather to Europe (ibid). Furthermore, from 1810 to 1865, the decrease in cotton production in the United States during the Civil War positively impacted São Luis export industry by making it the main region of the production of cotton for England and other European nations (ibid).

In the middle of the eighteenth century, colonial laws prohibited the use of indigenous slaves on plantations, and so with the increase of cotton plantations in Maranhão, more black slaves were shipped to the region (Goulart 1975, 155 as cited in

17 The Brazilian Institue of Geography and Statistics or IBGE is the agency responsible for official collection of statistical, geographic, cartographic, geodetic and environmental information in Brazil 
Silva 1995). The demand for plantation hands with the economic boom and the need for black slaves were often accompanied with intensified inhumane exploitation that led to conflicts between the slaves and slave owners. In 1838, this tension led to an armed insurrection known as the Balaida in the interior of Maranhão. The white elite fought and defeated the slaves and the indigenous workers that joined in the conflict. As Brazil faced abolition at the end of the 1800 s and cotton production for Europe declined, the Maranhese plantation owners employed its bandeirantes inhabitants by buying more black slaves from other states to revive its waning plantation economy.

The abolition of slavery in Brazil in 1888 and the recovery of the American economy post-Civil War negatively impacted Maranhão’s plantation production of cotton (Levine 1999). This economic declination also decreased the importance of São Luis and the state of Maranhão in the newly emerging Brazilian Republic. Maranhão’s plantation industry was then replaced by subsistence farming and animal husbandry, decreasing the availability of agricultural jobs that served the states peasant blacks, mestizos and indigenous populations in the rural interior of the state (Goulart 1975). Some of the peasant populations began to grow babaçu palms for oil. From the late $19^{\text {th }}$ century until mid- $20^{\text {th }}$ century, most inhabitants found employment in the state's growing industry of textile production. In fact, Maranhão's economy suffered tremendously to the extent that it created the foundations of its status as the most impoverished state in Brazil until today.

In the era of Brazilian modernization and industrialization, the federal government started to extract aluminum and iron from mines in the interior of Maranhão (Levine 1999). To sustain this capitalist endeavor, the state constructed transportation infrastructures such as highways, bridges, and railroads that connected the mineral 
mining areas in Maranhão, the Amazon and the ports of São Luis. Consequently, through this industrial revolution, the economy and employment opportunities in the construction, maritime trading and mining of São Luis grew vastly. By the mid- $20^{\text {th }}$ Century when many black Brazilians were moving from Nordeste to the Industrial south in search of better economic opportunities, Maranhão and São Luis experienced a different migration turn. Many of the poor working black population emigrated from the rural interior of Maranhão into the city of São Luis. Others joined them from the sertão areas of Piaui and Ceará (Lima, 1981;Meireles, 1980; Sampaio and Rocha 1989). This mass movement of poor working class people into São Luis changed the city’s demographic immensely-a predominant number of blacks and indigenous populations who settled into the periferias $^{18}$ came to outnumber the white elite class already living on the island.

\section{Socioeconomic Contextualization:}

According to the IBGE 2000 census, the State of Maranhão today has the eighth largest Afro-descendant population in the Brazil. The same census also reported that the population of the city of São Luis is $68.4 \%$ black, making it the tenth largest blackinhabited city in Brazil (See Table A through E below).

Table A: Racial Composition for the state of Maranhão and the City of São Luis

\begin{tabular}{|c|c|c|c|c|c|}
\hline \multirow[t]{2}{*}{ Racial components: State of Maranhão, 2000 Census } & \multicolumn{5}{|c|}{ Racial Composition of Maranhão's Population } \\
\hline & $\begin{array}{l}\text { Negros } \\
\text { (Blacks) }\end{array}$ & $\begin{array}{l}\text { Brancos } \\
\text { (Whites) }\end{array}$ & $\begin{array}{l}\text { Amarelos } \\
\text { (Asian) }\end{array}$ & $\begin{array}{l}\text { Indigenas } \\
\text { (Indigenous) }\end{array}$ & Total \\
\hline Non-Metropolitan Municipality & $73.4 \%$ & $26.0 \%$ & $0.1 \%$ & $0.5 \%$ & $100 \%$ \\
\hline Urban Clusters of São Luis & $68.4 \%$ & $31.1 \%$ & $0.2 \%$ & $0.3 \%$ & $100 \%$ \\
\hline
\end{tabular}

18 The outskirts of the city, characterized by squatter settlements and slum infracture 


\begin{tabular}{|c|c|c|c|c|c|}
\hline City of São Luis & $68 \%$ & $31.5 \%$ & $0.1 \%$ & $0.4 \%$ & $100 \%$ \\
\hline The State of Maranhão & $72.4 \%$ & $26.9 \%$ & $0.1 \%$ & $0.5 \%$ & $100 \%$ \\
\hline
\end{tabular}

Note: LAESER IE-UFRJ from the microdata of the sample of $10 \%$ of the Census 2000 / IBGE. Negros = pretos (black) + pardos (brown)

Table B: Illiteracy Rate amongst the population of the State of Maranhão above the age of 15 years old by race or color in 2000 Census.

\begin{tabular}{|c|c|c|c|}
\hline \multirow[t]{2}{*}{ Racial components: State of Maranhão, 2000 Census } & \multicolumn{3}{|c|}{ Functional Illiteracy Rate } \\
\hline & Rate of Illiteracy of Blacks (Negros) & Rate of Illiteracy of Whites (Branco) & Black/White \\
\hline Non-Metropolitan Municipality & $56.7 \%$ & $47.8 \%$ & $18.7 \%$ \\
\hline Aggregation of Urban Areas of São Luis & $18.8 \%$ & $12.4 \%$ & $50.9 \%$ \\
\hline City of São Luis & $17.6 \%$ & $11.1 \%$ & $58.6 \%$ \\
\hline The State of Maranhão & $49.3 \%$ & $39.3 \%$ & $25.3 \%$ \\
\hline
\end{tabular}

N/B: LAESER IE-UFRJ from the microdata of the sample of $10 \%$ of the Census $2000 /$ IBGE. Negros $=$ pretos (black) + pardos (brown).

Table C: Average income of the Main Employment according to Racial/Color groupings and gender in Maranhão's 2000 census:

\begin{tabular}{|c|c|c|c|c|c|c|c|}
\hline $\begin{array}{c}\text { Municipalities in the } \\
\text { State of Maranhão }\end{array}$ & \multicolumn{7}{|c|}{ Average Monthly income from the Main Employment in Brazilian Reias (RS) } \\
\cline { 2 - 7 } & $\begin{array}{c}\text { Black } \\
\text { Men-BM } \\
\text { (Negros } \\
\text { Homens) }\end{array}$ & $\begin{array}{c}\text { Black } \\
\text { Women-BW } \\
\text { (Negras } \\
\text { Mulheres) }\end{array}$ & $\begin{array}{c}\text { White Men- } \\
\text { WM } \\
\text { (Brancos } \\
\text { Homens) }\end{array}$ & $\begin{array}{c}\text { White Women- } \\
\text { WW (Brancas } \\
\text { Mulheres) }\end{array}$ & BM/BW & WM/BW & WW/BW \\
\hline $\begin{array}{c}\text { Non-Metropolitan } \\
\text { Municipality }\end{array}$ & $\mathrm{R} \$ 227.09$ & $\mathrm{R} \$ 163.84$ & $\mathrm{R} \$ 369.85$ & $\mathrm{R} \$ 164.22$ & $38.6 \%$ & $125.7 \%$ & $0.2 \%$ \\
& & & & & & \\
\hline
\end{tabular}




\begin{tabular}{|c|c|c|c|c|c|c|c|}
\hline $\begin{array}{c}\text { Aggregation of Urban } \\
\text { Areas of São Luis }\end{array}$ & $\mathrm{R} \$ 455.12$ & $\mathrm{R} \$ 312.01$ & $\mathrm{R} \$ 974.76$ & $\mathrm{R} \$ 549.76$ & $45.9 \%$ & $212.4 \%$ & $76.2 \%$ \\
\hline City of São Luis & $\mathrm{R} \$ 484.01$ & $\mathrm{R} \$ 324.14$ & $\mathrm{R} \$ 1068.58$ & $\mathrm{R} \$ 594.42$ & $49.3 \%$ & $229.7 \%$ & $83.4 \%$ \\
\hline The State of Maranhão & $\mathrm{R} \$ 267.86$ & $\mathrm{R} \$ 190.33$ & $\mathrm{R} \$ 502.14$ & $\mathrm{R} \$ 248.53$ & $40.7 \%$ & $163.8 \%$ & $30.6 \%$ \\
\hline
\end{tabular}

N/B: The statistics of functional illiteracy is invariably higher for blacks in both the state of Maranhão and the city of São Luis. According to IBGE 2000 Census, this indicator is directly correlated to the earnings of black workers in the city as indicated in the table above. According to the 2000 census inequalities along racial/color lines are latent and historically constructed.

Table D: The following table presents data on emigration (part of the population that left the municipality between 1995 and 2000) and immigration (people who moved into the municipality between 1995 and 2000) in the municipality of São Luis, including the immigration process of the proportion of the workforce considered as qualified (people with at least 1 year of higher education attended)

Emigration and Immigration Rates for the State of Maranhão and City of São Luis

\begin{tabular}{|l|l|l|}
\hline Migration & $\begin{array}{l}\text { Emigration minus } \\
\text { Immigration }\end{array}$ & $\begin{array}{l}\text { High school Literate Emigrants } \\
\text { minus High school-Literate } \\
\text { Immigrants }\end{array}$ \\
\hline
\end{tabular}




\begin{tabular}{|l|c|c|}
\hline City of São Luis & -2.082 & 283 \\
\hline $\begin{array}{l}\text { The State of } \\
\text { Maranhão }\end{array}$ & 119.902 & -1.3332 \\
\hline $\begin{array}{l}\text { Northeastern } \\
\text { Brazil } \\
\text { (O Nordeste) }\end{array}$ & $1,076.568$ & -9.635 \\
\hline $\begin{array}{l}\text { N/B: The population of High school literate emigrants/immigrants represents those } \\
\text { who have at least a year of the equivalent of } \mathbf{8}^{\text {th }}-\mathbf{9}^{\text {th }} \text { grade education. } \\
\text { Source: IBGE Population Census 2000 }\end{array}$ \\
\hline
\end{tabular}

Table E: Below, I provide additional important statistics detailing various factors that has impacted São Luis' socioeconomic and sociopolitical developments along racial lines.

Data published by São Luis's local government's www.nossaSãoluis.org.br (retrieved on 12/13/2015)

\begin{tabular}{|l|r|}
\hline \multicolumn{1}{|c|}{ Social Issue } & \multicolumn{1}{c|}{ Condition and Sector of Population Affected } \\
\hline $\begin{array}{l}\text { Concentration of Income and } \\
\text { salary for workers }\end{array}$ & $\begin{array}{l}\text { In 2010, per every 56.76\% of registered workers with a } \\
\text { minimum of two sources of employment/income reported } \\
\text { earning approximately } 22.23 \% \text { below the state minimum } \\
\text { wage. }\end{array}$ \\
$\begin{array}{l}\text { Of all workers registered, those who received at least } 15 \\
\text { weekly wages throughout the year, } 21.83 \% \text { earned below the }\end{array}$ \\
\hline
\end{tabular}




\begin{tabular}{|c|c|}
\hline & state minimum wage. (Source: RAIS/CAGE/MTE) \\
\hline $\begin{array}{l}\text { Neonatal Care by } \\
\text { Race }\end{array}$ & $\begin{array}{l}\text { According to DATASUS: } \\
\text { - Non-blacks account for } 8 \% \text { of surviving children born under } \\
\text { 5.5lbs, while black children born underweight } 6.8 \% \text {. } \\
\text { - Of all children born alive, } 38.06 \% \text { of non-black mother's } \\
\text { account for those received at least } 7 \text { prenatal care } \\
\text { appointments while } 66.99 \% \text { account for black mothers who } \\
\text { received one or zero prenatal care appointments. } \\
\text { In } 2009 \text {, Black mothers account for } 20.87 \% \text { of all teenage } \\
\text { pregnancies (under } 20 \text { years of age), while } 12.27 \% \text { are non- } \\
\text { black }\end{array}$ \\
\hline $\begin{array}{l}\text { Education and Standard Test } \\
\text { Rates (Vestibular-High School } \\
\text { entrance exams) }\end{array}$ & $\begin{array}{l}\text { According to INEP/MEC school census: } \\
\text { - For all students in the public sector } 11.70 \% \text { who fail the high } \\
\text { entrance exams (vestibular) in } 2009,40 \% \text { were black } \\
\text { students. } \\
\text { - In } 2010 \text {, of the } 13.80 \% \text { of all students who failed the } \\
\text { vestibular, } 60 \% \text { were black students. } \\
\text { N/B: The census noted that there was a direct correlation } \\
\text { between exam passage rates along racial lines, affected by } \\
\text { factors such public safety, general health, poverty rates and } \\
\text { homelessness }\end{array}$ \\
\hline
\end{tabular}

\section{Contextualizing São Luis’ Cultural Heritage:}

At first appearance, São Luis seems to have a strange Wild West character to its setting. However, on careful examination, you will come to appreciate this for what it truly is - an archetypal coastal and rugged nordestino city with deteriorating colonial architecture and weathered infrastructure. In comparison to the industrial south, the northeastern region of Brazil is known to be the more economically disadvantaged region of the nation. The state of Maranhão along with its capital city São Luis have felt the 
brunt of the northeastern impoverishment due to complex Brazilian historical politics as described above. Yet, somehow the city of São Luis has managed to preserve, albeit poorly, a good amount of its colonial Portuguese architectural heritage. In 1997, the city's historic center, Centro historico was designated a UNESCO World Heritage site. Although showing its centuries worth of dilapidation, several colonial buildings such as the Palacio De Justicia (Justice Palace), together with the many colonial homes (now turned tourist shops in the historic center), continue to showcase the city's glorious aristocratic past (See Photos 6 through.

Formerly known as Brazil's Athens, São Luis used to be the home city of many great essayists, poets, playwrights and powerful aristocratic families whose former homes and places of worship still grace the city center's Praia Grande (also known locally as “reviver").

\section{Photo 6 : São Luis' Heritage Cathedral, Centro Historico (Picture taken by Ribamar Nascimento)}




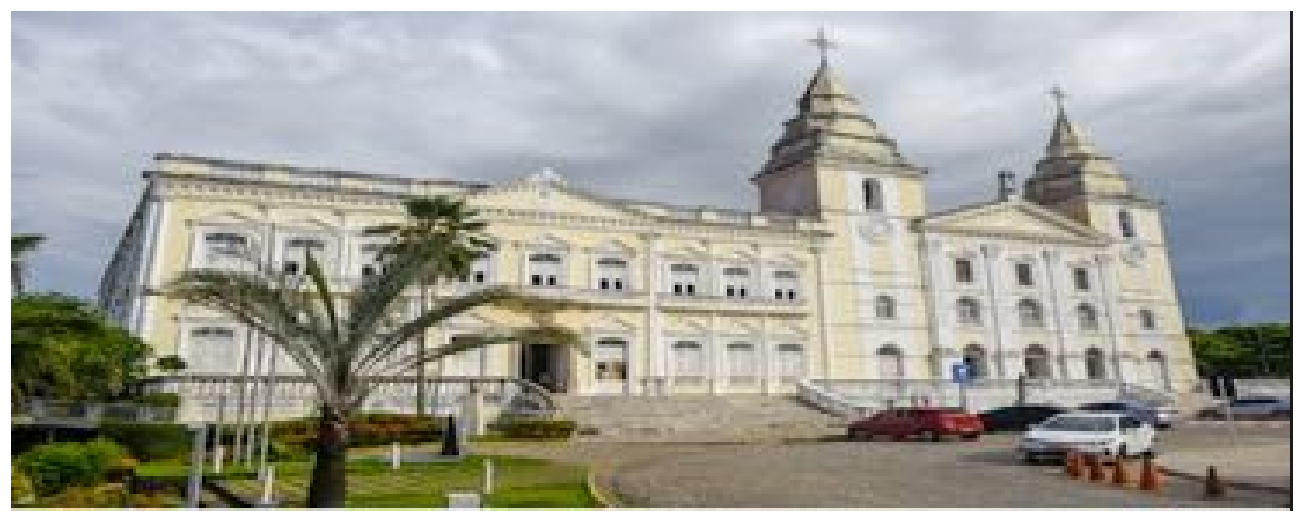

\section{Photo 7: São Luis' Heritage House of Parliament, Centro Historico (Picture taken by Ribamar Nascimento)}

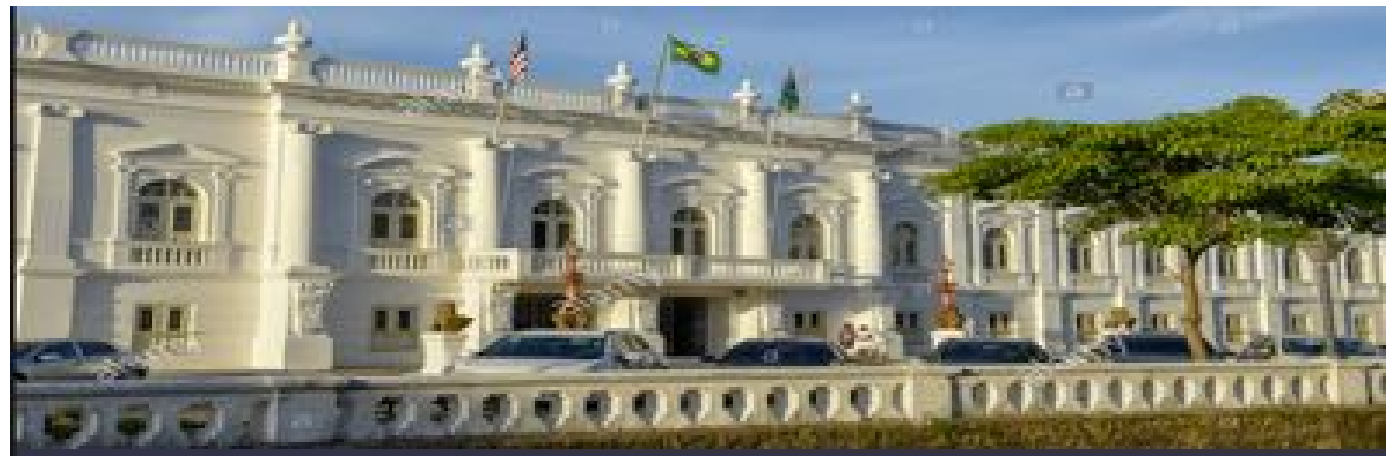

The picturesque azuelos (distinctive European blue and white tiles shipped to the city's colonial times) cover the many buildings on Lisboa's bairro alto that are practically falling apart. (See Photos 8-12 below) Several of these dilapidated buildings are not only at the verge of collapsing but many have weeds and whole trees sprouting through their walls and roofs. 
Photo 8-12: São Luis' Heritage Centro Historico, also known locally as "Reviver" (Picture taken by Ribamar Nascimento)

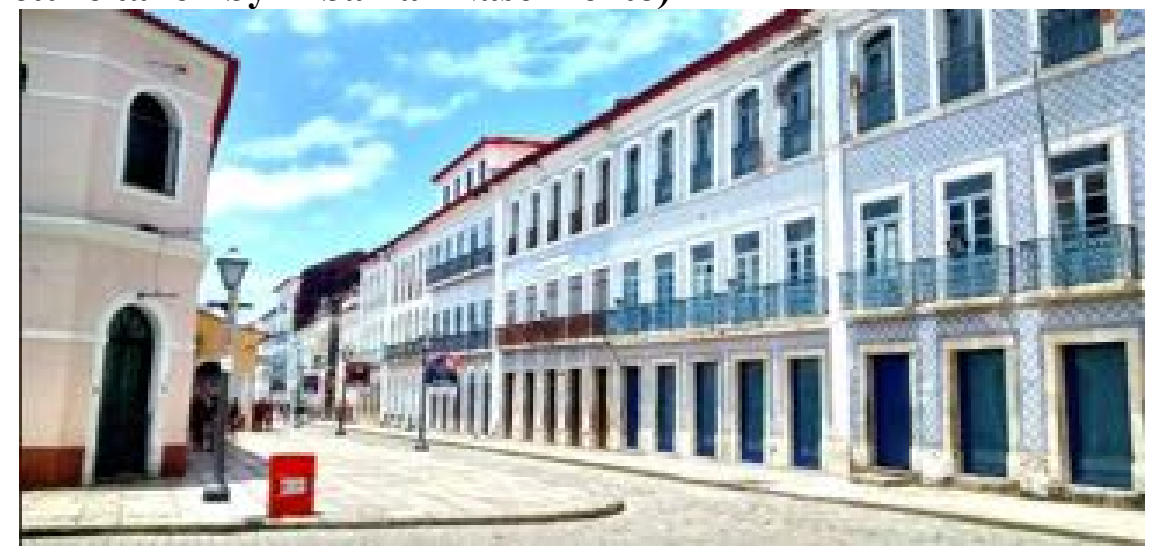

Photo 8

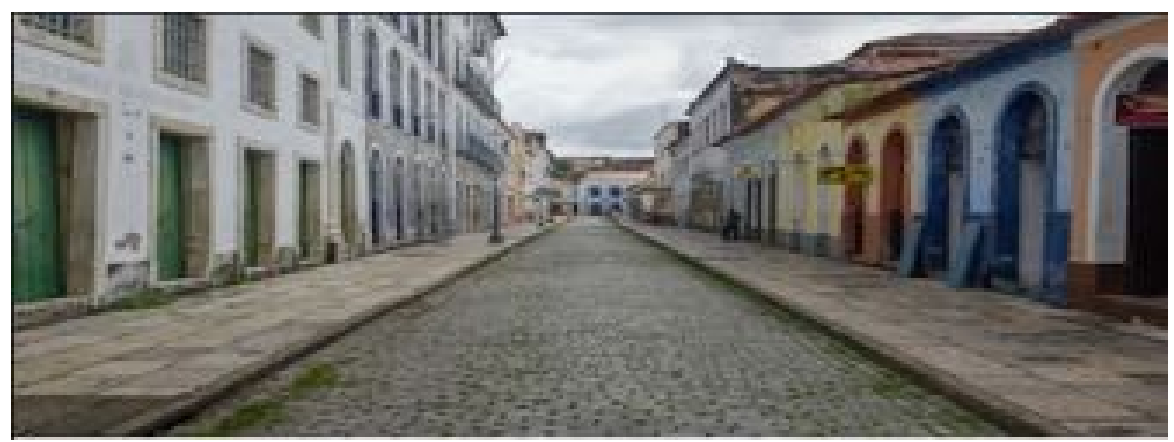

Photo 9

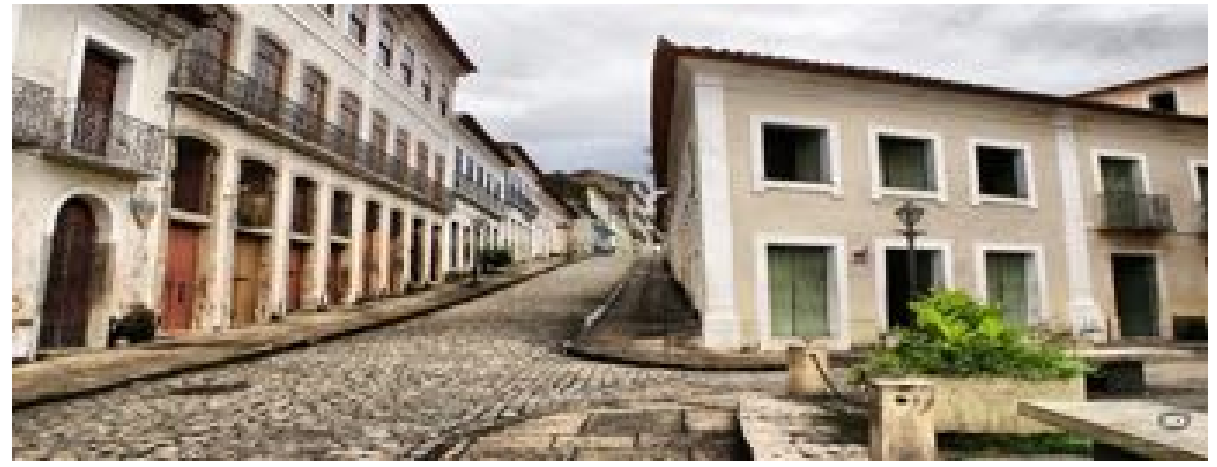

Photo 10 


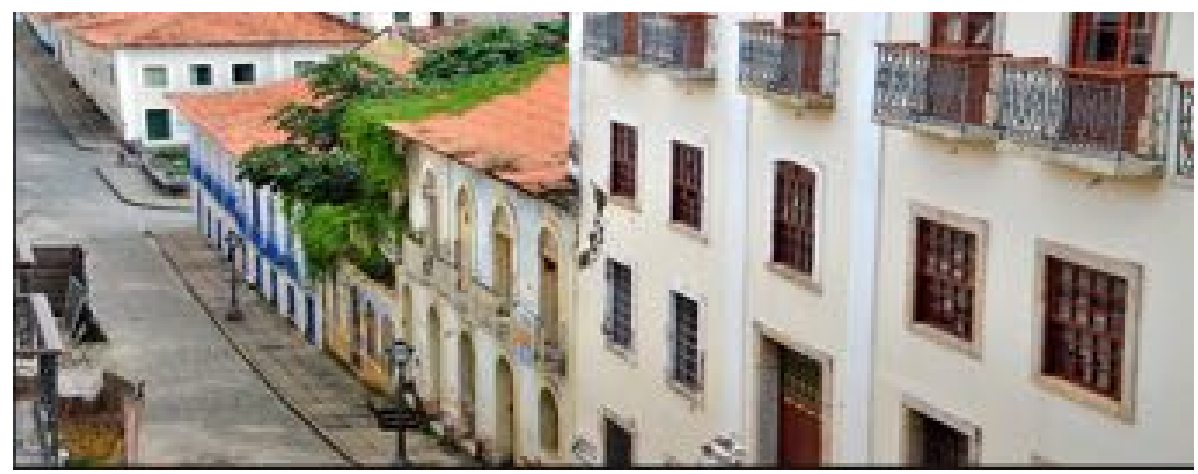

Photo 11

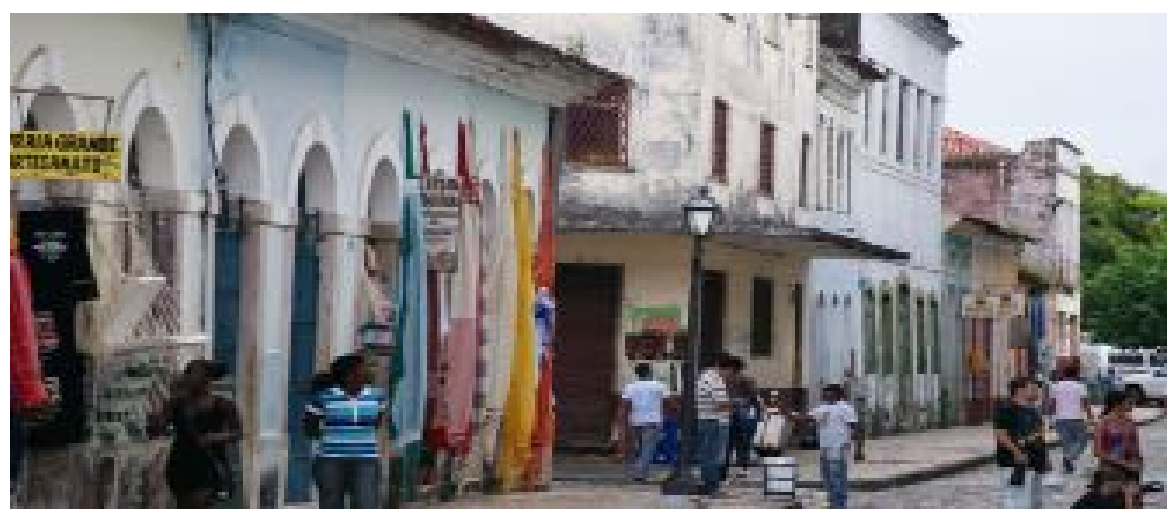

\section{Photo 12}

Today, although most of these buildings in the city serve as tourist attractions and artisanal shops for Maranhese handcrafted items, the remnants of these colonial homes tell a long history of social and cultural inequalities that black and indigenous populations have endured over the years. Most of these elaborate mansions and churches in the historic center as recounted by Mérieles (1980) were the interactive spaces allotted to only the aristocratic elite of Maranhese society. While black slaves and their descendants physically built these spaces and contributed massively to its culture, their access to these spaces have always been subjugated and policed, even up until today (ibid). Ferretti $(2008,1996)$ asserts that the historic center of the São Luis did not only serve as homes 
and places of worship for the elite but it has always been the center of the city's cultural celebrations.

The black festivals, religious practices and musical and dance celebrations that were deemed dignified in the eyes of the predominantly Maranhese merchant bourgeoisie were the ones allowed to be celebrated in the city's center (ibid). The celebrations that were seen as barbaric African superstitions and practices were never allowed in these spaces.

Silva (1995) states that that this history of access and the policing of the culture of São Luis’ poor black population form the foundation of cultural censorship today. He insists that this history of discriminatory impositions on where and how the dances, the songs, the religious practices and oral traditions of Afro-Brazilians in Maranhão and São Luis can be performed, has impacted how modern forms of black culture such as roots reggae music and reggaeir@ismo has been perceived by the elite. Consequently in this dissertation, I explore the manifestation of documentary practices of surveillance of reggaeir@ spaces as seen in the regulation of event licensing and police brutality in controlling reggae performative spaces in the city.

\section{Roots and Routes: How Roots Reggae arrived in São Luis do Maranhão}

During my exploratory research in 2010, I engaged in several informal conversations with reggaeir@s around the island. In a conversation with a local reggae DJ, Jorge Black who visits Jamaica quite frequently, I was informed that the Jamaican recording artists, George Faith, Joe Gibbs and Gibbs' producer, Sidney “Luddy” Crooks all live in São Luis and are married to local Maranhese women. Other locals also mentioned that the UK's infamous reggae ballad artist; Crooner Honey Boy has also been 
living in São Luis for several years, and continues to produce music on the island. From these accounts, I mistakenly assumed these Jamaican artists and many others who continue to recycle and reproduce vintage-style roots reggae music specifically for the Maranhão scene are the reasons why roots reggae came to the island. However, my assumptions were very far from the truth, as I detail below.

According to local legends, reggae and dancing agarradinho were introduced to the island in two ways: Many locals claim that in the 1960s and 1970s through maritime trade, many Caribbean sailors especially those from nearby Guyana frequented the ports of São Luis. These sailors brought with them what was then known as "international music", which was reggae music. When the sailors interacted with Maranhese sex workers on the ports, they would entertain the women by dancing with them in closeembrace ballroom styles that were popular in the Caribbean. It also gave them the opportunity to "discreetly" communicate to the sex workers what services they wanted from them without the interference of others on the ports of São Luis ${ }^{19}$ (See Photo 13 below).

19 This account was based on three conversations with the researcher: 1. Ari da Silva Araujo in Reviver, São Luis May 22 ${ }^{\text {nd }}$ 2010; Ana Regina Azevedo Santiago, João Paulo, São Luis, July $3^{\text {rd }}$ 2016; Natalia Soares, Bar Nelson, Litoranea, June $4^{\text {th }} 2016$ 
Photo 13: Couple dancing agarradinho in 1973 (Picture taken from the archives of the reggae museum in Centro Historico, São Luis)

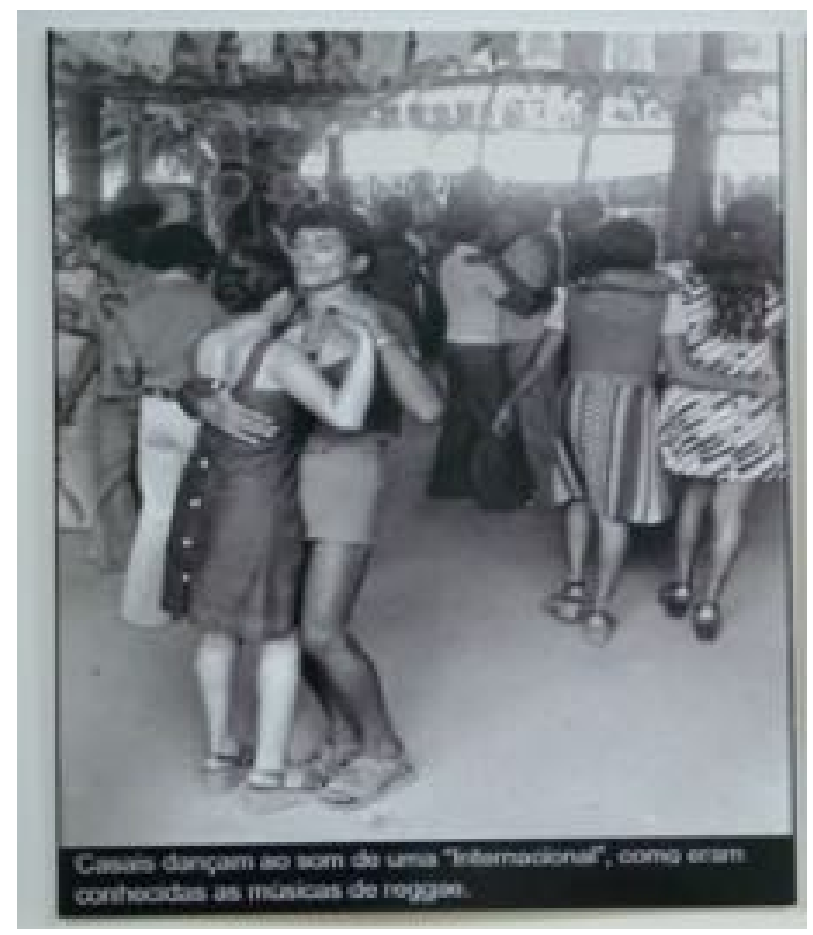

The other legend, although similar, involved the nearby Amazonian ports of Belém. Locals believe that when Caribbean sailors through maritime trade sailed the ports of Belém, they traded their Caribbean vinyl records with sex workers at the port in exchange for their services. A record storeowner in Belém named Carlos bought the records from the sex workers and then sold them for more in his store. Circa 1976, on a business trip to São Luis, Santos was introduced to Riba Macedo, a music aficionado and music collector. In order to establish a solid business relationship with Macedo in São Luis, Santos gifted Macedo several records that included Monkey man (See photo 14 below) by the band Toots and the Maytals playing and The Front Line by Norlan Porter. Macedo who was captivated by the sounds of reggae, would often organize parties in his 
neighborhood and play these records until it caught on to other periferias nearby (Silva 1995; Freire 2007).

\section{Photo 14: The Maytals Monkey Man Album}

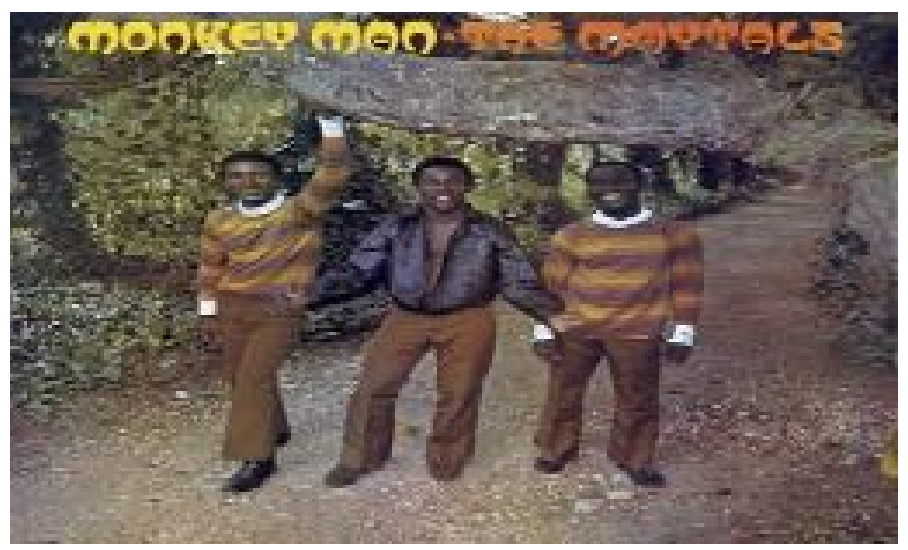

Those who believe the account that Macedo was the reason why reggae came to São Luis simply rationalize its association with agarrado dancing by saying that the rhythms of reggae music just so happen to fit the style of ballroom dancing that already existed in São Luis as seen with local dance styles such as forró, merengue and boléro. They say that the locals just knew to dance to roots reggae in coupled-embraced style because it was the way of dancing to any music that was classified as "international". Irrespective of the legend that holds truer than the other, adults and children alike recount these legends with so much passion and as absolute truths to the extent of enamory to outsiders who visit the island. Based on my research, I found out that the legend are actually exaggerated versions of two different historical accounts in the 1960s, and there seemed to be partial evidence to support either account as I show in the next section of this chapter. 


\section{Cultivating Local Music and Dance Practices through Global Afrodiasporic Musical}

\section{Forms:}

In this section of this chapter, I rely mainly on my interviews, documentary and archival accounts to trace the various historiographies that has informed the creation of reggaeir@ performative spaces and how blackness has been articulated in these spaces.

In the early $20^{\text {th }}$ century, Caribbean sounds and rhythms such as danzón, son, mambo, guarachá and the bolero informed many musical traditions in the Latin American region (Guerrero 2010). Advances in recording and commercialization contributed immensely to musical forms such as bolero in Mexico, which soon spread to other Latin American spaces. In the middle of the $20^{\text {th }}$ century, Brazil's urban middle class had just started to embrace new cultural forms from the Caribbean in Rio de Janeiro and São Paulo. As recounted by Tinhorão (2010),

Thanks to a positive trade balance from the sale of raw materials during the war, the country opened its doors to imports. The urban masses indulged in shopping sprees to bring them closer to modernity, through the use of Ray-Ban sunglasses and blue jeans, the consumption of whiskey, the search for adventure in shadowy nightclubs... and, naturally, through the popular rhythms of the day played by international band-fox-blu, bolero, calypso and finally, from the 1950ss onwards, rock ' $n$ roll (307)

In the 1940s, bolero gained popularity in Brazil due to the introduction of Mexican films and their soundtracks such as Santa-O Destino de uma Pecadora in 1945 and Palabras de Mujer in 1946. The artist Francisco Alves released versions of boleros in Portuguese that became very popular in the late 1940s alongside many others. At the same time, samba musicians engaged the transnational dialogue that tied together North American jazz, the Caribbean bolero, and Brazilian samba (Sheriff 1999). With these 
transnational engagements in various music forms, boleros helped to strengthen the budding genre of samba-canção. Samba-canção artists such as Lupicínio Rodrigues and Herivelto Martins then incorporated bolero style into their compositions, producing a percussive, polyrhythmic musical form that became known as sambolero.

Nightclubs in the Southeast of Brazil would play boleros, samba-canções and samboleros interchangeably for their patrons that would often dance in pairs. At the same time, because radiostations often played samba-canção on their broadcasting networks nationwide, boleros and other Caribbean rhythms, melody and tempos became very familiar in Brazil, especially in Belém and São Luis. In the early 1950s and 1960s, the size of São Luis' and Belém's urban middle class population were comparatively smaller in relation to that of their southeastern counterpart cities of São Paulo and Rio de Janeiro. There are elite couples in these social classes limited their spaces of leisure and entertainment to only members of that class. Their social clubs and salons provided the spaces for them to dance boleros and samba-canções, which often excluded the poor black population in São Luis (Gonzalez et. al. 2017).

\section{Routes to the Black Atlantic: Historiographies of São Luis' connections to the}

\section{Caribbean}

Through my interviews, I discovered accounts that claimed that due to São Luis' geographical proximity to the Caribbean, the city could pick up radio signals and broadcastings from the Caribbean. As such, although the poor black populations were excluded from the high society dance spaces, they would listen to boleros on AM Radios in their neighborhoods. Additionally, maritime trade sailors from the Caribbean who 
brought their musical forms with them to the ports of São Luis introduced the poor black working class people to the musical forms from the Caribbean region.

Geographically, the island of São Luis lies at the farthest southwestern part of a coastal transportation line that connects the city to the southern Caribbean via the lowland riverline basin known as the baixada maranhese. It is also connected via Belém do Pará at the mouth of the Amazon River. Trade between São Luis and the Caribbean had predominantly been through the sea route mainly for safety reasons. In the midcentury, many travelers and sailors traded in between Brazil and the Caribbean via Belém and Guyana. (See Map C below) Smaller cargo ships that sailed between Paramaribo, Suriname and Cayenne, French Guiana regularly docked at Belém and São Luis in the 1950s and early 1960s (See Photo 15 below).

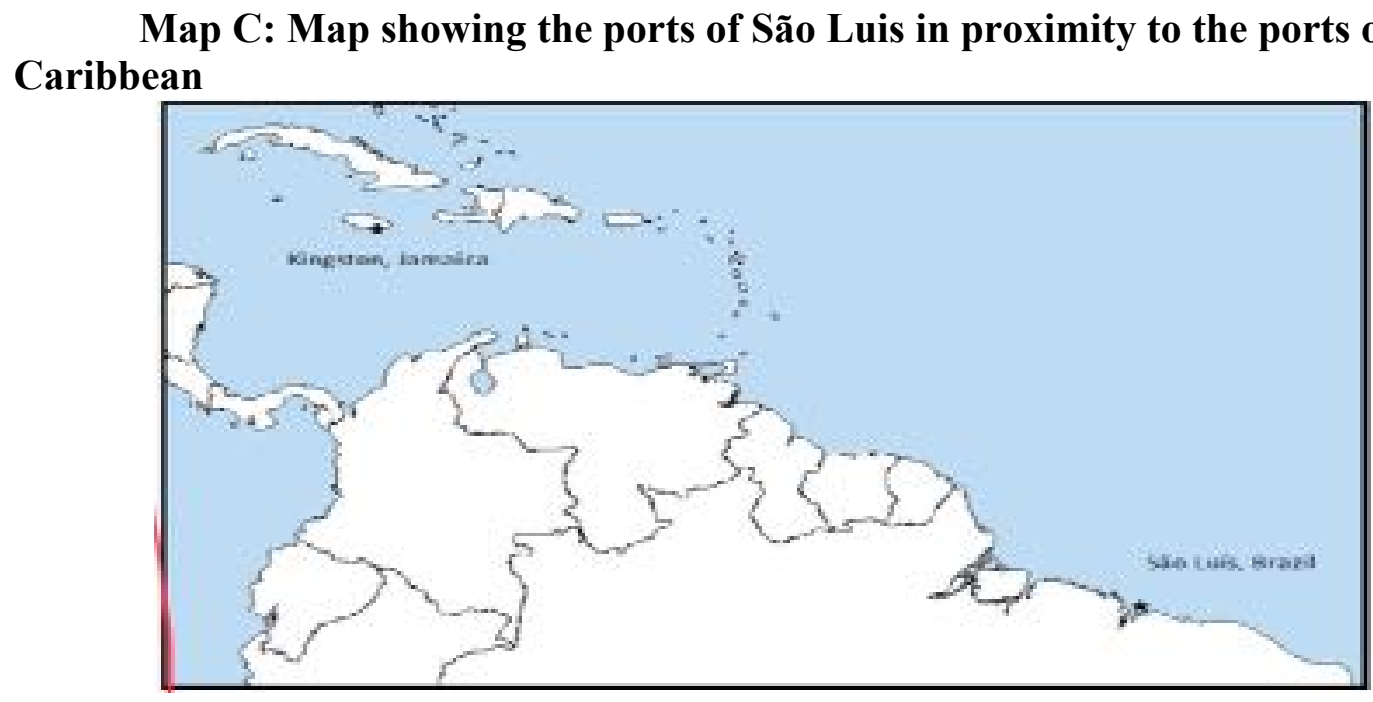




\section{Photo 15: Maritime trade ports in 1975 (Picture taken from the archives of the reggae museum in Centro Historico, São Luis)}

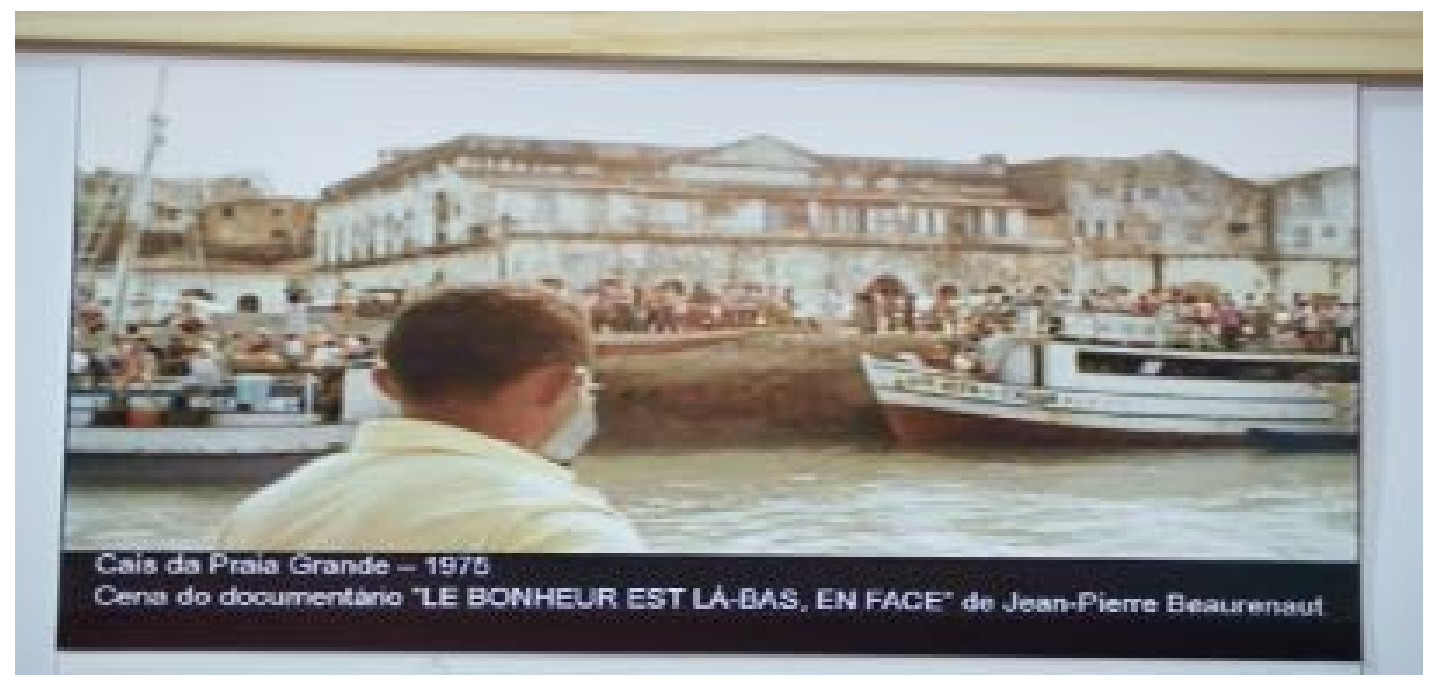

Against the Brazilian government's strict tariffs during this time, sailors engaged in the most profitable maritime contraband trade along the São Luis-Guyana transportation line. Ships that carried Brazilian coffee to the Guyanas for resale on the World market would also illegally import a variety of contraband like alcohol and tobacco products (Lamen 2013). Brazilian armed force patrols intercepted vessels along the coast of Maranhão, Pará and the federal territory of Amapá (ibid). The vessels then docked in smaller ports of the baixada maranhese but would frequently be caught by the armed force patrols. As a result of this, these sailors started to strategically schedule their stops in São Luis or Belém, sometimes skipping stops at these ports to travel on directly to the Guyanas (Jornal Pequeno, March 7 1961).

These ships and sailors from the Caribbean that docked in São Luis carried music from their homelands with them. Archival accounts show that the preferable style of 
music between the late 1940s and the early 1950s were music forms such as Cuban mambo, Trinidadian calypso and Haitian meringue as well as bolero. Older interviewees from my research recount how Caribbean sailors brought their music to the bars and music spaces near the ports where their ships were docked. By the early 1960s, the musical form called the merengue became the latest international favorite in the coastal areas of Maranhão and Para.

During these times, news and media outlets also reported an increase in maritime smuggling during this time as more Caribbean sailors docked at the ports of these areas. The genres of cadence/ kadans and compas/kompa from the French Caribbean, Columbia cumbia and Dominican merengue also became popular. Bands and their leaders such as Luis Quintero, Angel Viloria, Trio Reynoso and other merengue musical forms like perico ripiao from the Dominican Republic became household names in São Luis. Additionally, supergroups like Aníbal y su Conjunto and Los Corraleros de Majagual popularized cumbia and guarachá in the early 1960s (Farias 2011). Fifty years later, popular cumbia songs of the 1960s such as Cumbiamberit", Festival en Guararé, and La Pollera Coloral were still played in São Luis.

With the availability of all these Caribbean musical forms, locals grouped them all under the umbrella name of "merengue" (Silva 1995). Although boleros were popular amongst various class demographics, merengue and cumbia were seen as working class music forms (ibid). In port cities like São Luis, sailors, travel merchants, sex workers and all other members of the working class frequented bars near the ports to enjoy merengue. According to Silva's (1995) account, the elite shunned the playing of merengue in their social clubs because it was often associated with sex workers and the Caribbean sailors 
who frequented the ports. Additionally, radio stations did not play merengue and cumbia as much as they did boleros due to lack of availability of records from distributors and labels. However, rural communities along the coast as well as the working class migrants who moved into the cities of Maranhão and Pará were more open to playing and dancing to the newer forms styles alongside the Caribbean boleros and other Brazilian forms. While many working class communities could not afford to import records and sound equipment, they improvised with their own innovations and built their own sound systems.

Firstly, the Caribbean music forms couched under the term merengue did not fare as well in the Southeastern cities of Brazil because most people were more captivated by northern American music forms such as rock and roll. Secondly, at the heights of the promotion of Brazilian mestiçagem and racial democracy, policy makers and musicologists were more invested in promoting Brazilian genres in the name of nationalism. Through discourses of hybridity, bossa nova and tropicália were deemed as imitations of jazz and pop music, while boleros and northeastern popular forms also became associated with rurality, vulgarity and backwardness (Silva 1995, Crook 2005). Caribbean forms such as cumbia and merengue were all lumped into the "primitive" musical forms of the working class. Consequently, many Southeastern industrial cities eliminated most of these musical forms due to stigma. However, working class populations in the Nordeste cities maintained these musical and dance practices as their own in various hybridized versions, which were created out of necessity and survival in response to elitist exclusions in elite spaces. 


\section{Historicizing the Creation of the Reggaeir@Performative Spaces: Innovating with the Radiola/Sound System}

In the early 1960s, the black working class of São Luis listened to Caribbean music on the AM Radio Stations Gurupi, Ribamar and Difusora, yet there were no public spaces available to them as there were for the elite at their high society social clubs. In order to hear the hits songs on the radio at a working-class party, someone from the working class neighborhood had to bring a radiola or sound system. As such, the radiola functionally and literally became an extension of how the black people created the means of hearing their favorite Caribbean tunes.

Caribbean sailors and merchants brought to the ports of São Luis a version of premade systems, and locals began to make their own using products bought from the Brazilian South, using parts such as the ABC, Delta and EASA brands (Cassiolato and Matos 2007). The basic sound system is made up of three basic components; the audio input source (a radio or a record player), the amplifier, and the output device (a speaker). For the most part in the 1960s and 1970s, black working class people could not afford sound systems due the high costs of imported parts. They would often go to great financial lengths to obtain basic secondhand parts to build their own. Working-class electricians in black neighborhoods started to join efforts to build these equipment from scratch (Silva 1995). At other times, successful business owners made profits by renting these audio equipments, and have black workers pay for them to play at their neighborhood parties.

In order to build larger sound systems to use in their parties, electricians from black neighborhoods modified the sound systems to include an array of speakers to get 
better sounding radio frequencies. In the 1970 s, no more than four speakers were used at a time. They then put these innovations in rooms or local bars to create dance floors around them. The two leading sound systems in São Luis in the 1970s were Carne Seca (See Photo 16 below) and Nestábulo, which were built by black electricians and other tradesmen from various black neighborhoods (Da Costa 2010). Through these innovations, sound system owners, who were often middle-aged older men with community ties, became quite reputable in working class neighborhoods. Sound systems in the 1960s were often identified by the name of the owner so for instance Nestábula's sound system became known as Radiola do Nestábula (Jornal Itaqui-Bacanga 1983).

Photo 16: Radiola Carne Seca, one of the first reggae radiola 1975 (Picture taken from the archives of the reggae museum in Centro Historico, São Luis)

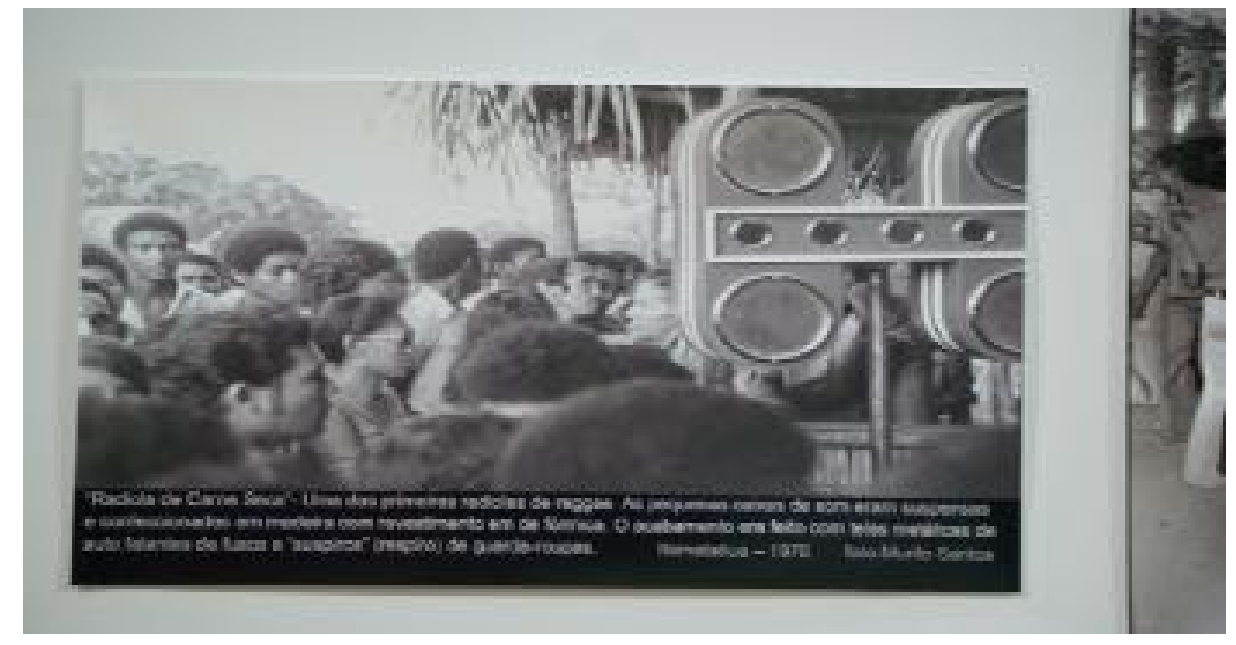

To create an event, these sound system owners needed help and so they brought along family members and their working class neighborhood friends who transported the speakers, connected the cables and stood guard during the events. Someone was also 
chosen to be the discotercário or the "selector" (who later became party disc jockeys or DJs), who picked the songs to play during the events.

In the 1970s, working class black people would choose listening parties based on the name of the owner of the sound system and the group of hired hands that had been employed to be selectors of the music from their own neighborhoods. Most sounds system owners purchased their LPs locally as they became available, especially the popular songs that were hits on the radio with working class people (See Photos 17-18).

\section{Photo 17-18: Current structures of Radiolas}

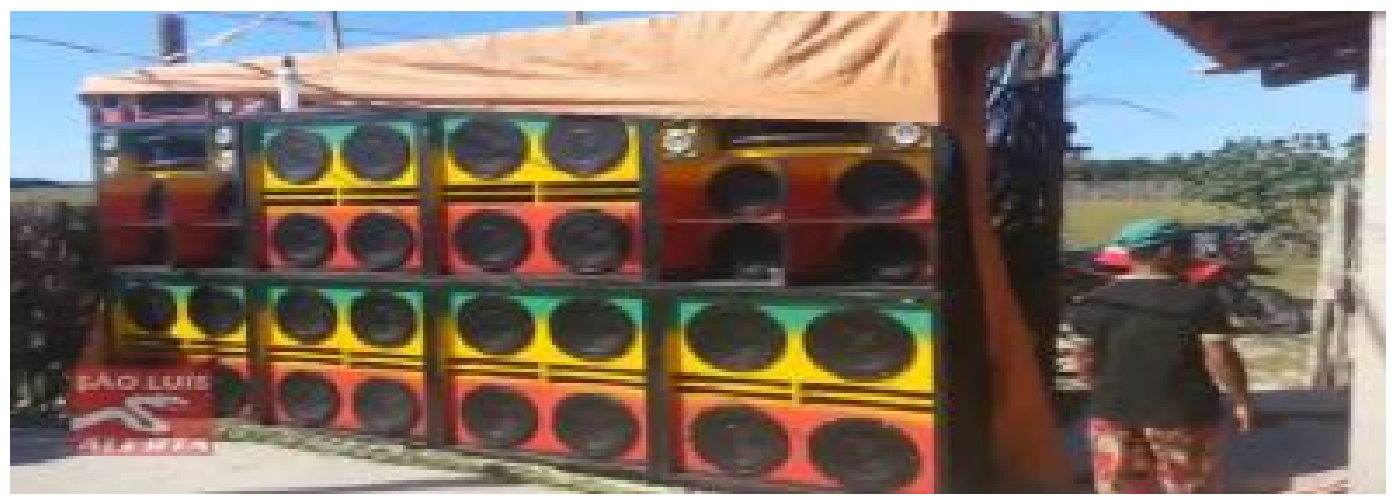

\section{Photo 17}

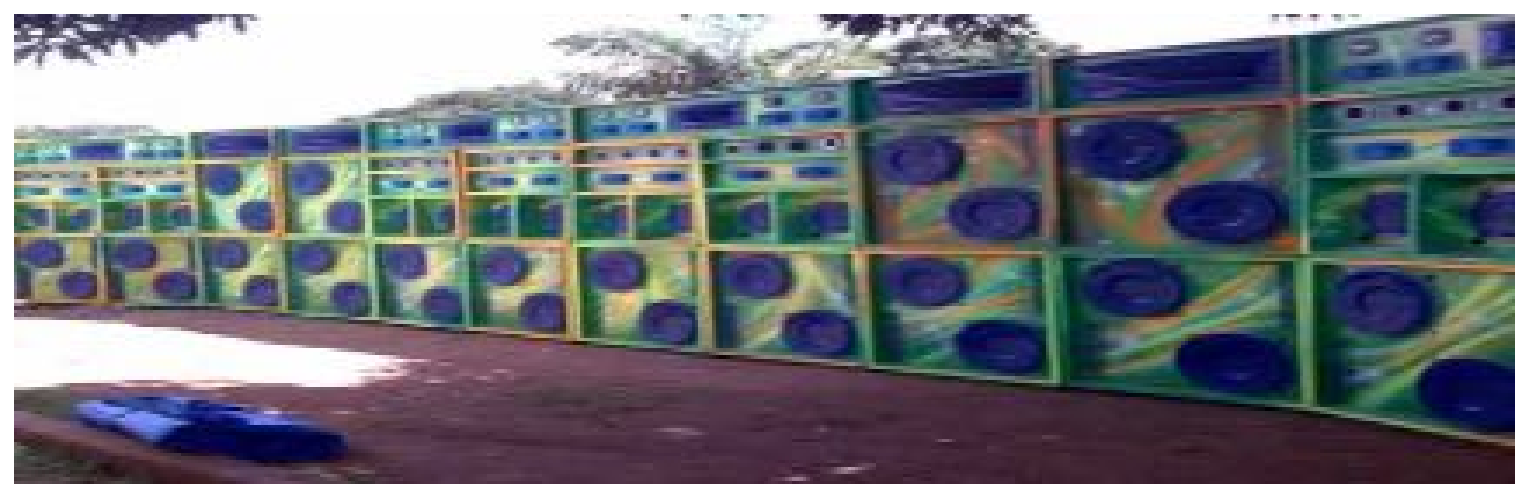

Photo 18 


\section{Articulations of Black Dance Practices in Local Spaces:}

The exclusion of working class black migrants in São Luis from the elite bolero dance halls did not only prompt them to find ways to create sound systems to listen to their favorite Caribbean music alongside other forms of "international music", it also prompted them to find ways create their own spaces to listen and dance to these musical forms. According to Silva (1995), migrants black workers that moved into the periferias of São Luis were already familiar with rural public festive spaces in their hometowns where Afro-religious practices often occurred. In the city, they restructured those spaces to listen and dance to international music in these spaces in their own neighborhoods. The creation of these spaces also contributed to the generation of revenue for the circle of sound system owners by providing the black working population in these festive spaces to play their favorite international hits.

As with the syncretizing of religious spaces with Caribbean music dance practices, the type of festive spaces that were later created around the city were all related to black seasonal festivities and religious practices in São Luis. So, for instance during carnival season in February, working class blacks often congregated in the city center, thus making places in the historic center new spaces for listening and dancing to "international" music. It is also worth noting that in order to maintain the cultural practices around samba and carnival, black neighborhoods in São Luis have always gravitated more towards other festive seasons on the calendar other than the month of February. These seasons include the festive month of June and July that features more 
folkloric and popular festivals such as Bumba-meu-boi (boi) and the Catholic festas do Juninas celebrating Catholics Saints such as São João, São Antônio and São Pedro.

Up until the late 1970s, the municipality of São Luis still maintained colonial prohibitions against African and indigenous celebrations in the city center (Silva 1995). Consequently, the black and indigenous working class populations kept their music and dance celebrations in the periferias they had migrated into, on the outskirts of the city. During bumba-meu-boi festivities in June, residents of the periferias set up tents to host araials or dance presentations for São João and other Catholic Saints. These tent spaces later became converted into dance spaces when sound system owners provided the equipment that could now be used to transmit Caribbean music. Hence, after the formal presentations to the Catholic Saints, these spaces were turned into "international music scenes" in the periferias. As early as the late 1960s, sound system owners such as Carne Seca began to organize arraials in open spaces on the northern bank of the river Bacanga for his neighborhood. Residents from black working class neighborhoods of Madre Deus and Lira squatter communities would flock to Carne Seca's sound system parties to listen and dance to international hits.

In addition to the boi and junina festivities that provided the space for Caribbean music, the festejos and festas do divino which are religious festivities held in spiritual houses such as Catholic churches and Afro-Brazilian Casas de Mina, Nago and jeje terreiros provided the space for working class black people to convert to Caribbean music dance spaces as well. Because these spiritual events are accompanied by music and dance traditions, participants who engaged in them were able to transferably convert 
them to dance spaces by employing sound system owners to play for them to attract more crowds. For example, in the periferia neighborhood of Liberdade, whenever the Casa de Mina (an Afro-Maranhese oríxa worship traditions) held its festival following the bumbameu-boi festival, the black worshippers would invite sound systems owners to come play for them. Later, Afro-spiritist house of Cosme and Damião followed suit by depending on the sounds systems for its annual festejo celebrations. All these spaces eventually became black performative spaces for poor working class black people to socialize and dance to popular music.

Later in the late 1970s, urban cultural associations such as samba schools and amateur athletic groups and neighborhood associations started renting out their spaces in the periferias to working class black people in their neighborhoods. In the process, soundsystem parties became routine in these neighborhoods. The spaces in the neighborhood association meeting places began to simulate bars and nightclubs at night. These spaces catered to sailors, sex workers and other working class populations by playing hybridized Caribbean tunes under the label "merengue". Businessmen like São Mateus, moved from the state of São Paulo to São Luis to capitalize on these spaces by building a nightclub called Rock Clube in the neighborhood of João Paulo, a merengue space that catered to sailors, two blocks away from the neighborhood association Beneficient Association of Barés (ABB). Other businessmen joined in the competition by building nightclubs that catered to the younger crowd. These dance spaces were incredibly successful, however in 1975, after several violent fights broke out in these spaces, the Baptist school in the same area forced many of the nightclubs to relocate to different places. 
By the end of the 1970s, many night dance spaces had sprawled around the periferias in São Luis catering to the "international" music needs of the black working class population. In the periferias of Liberdade, the black youth often gathered in the neighborhood association spaces to listen to Caribbean music. Across the river in São Francisco's periferias, in the cultural space known as Quilombo, residents routinely rented Carne Seca's sound system for parties. In the periferias of Fatima, Aurora and Sacavém, working class black people gathered on Sunday and Tuesday nights to dance to sound system music. "Selectors" began to gain more notoriety when these parties became the new norm. Young people from these working class neighborhoods who aspired to become "selectors" started to carry their LPs to these dance spaces hoping to be offered opportunities to play them.

\section{Transitioning from "merengue" and "International" Music to Roots Reggae:}

It is significantly important to understand the economics and commercialism of music collection that has been maintained in São Luis' connection to roots reggae music through the decades. I mentioned earlier in this work that in order for the reader to understand reggaeirismo in São Luis, it is important for one to abandon any ideologies connected to Jamaican politics, Rastafarianism, and the popularizing of black liberation and social movements messages that often accompanied reggae music in the Caribbean and around the world.

One way to abandon these ideas is to understand how the commercialization of Caribbean music production and collection has been maintained in São Luis. While the working class Ludovicenses innovated with sound systems and public cultural to play Caribbean sounds in spaces in their neighborhoods, black working class population that 
had migrated from the northeast into the urban slums of Brazilian Southeastern cities gravitated to other musical forms from Europe and the United States (Farias 2010).

The popularization of roots reggae in incidentally coincided with the emergence of the Black Soul movement of Afro-Brazilians in the southern cities of São Paulo and Rio de Janeiro. The Black Soul Movement was characterized by ostentatious expressions of black identity in fashion and music and dance (Telles, 2006). These ways of black articulations connoted moments where for the first time Afro-Brazilians sought to use connections to other diasporic Africans outside the African continent to mobilize themselves. Mobilization of the Brazilian black movement, movimento negro using music and dance forms played an integral part of the Afro-Brazilian experience and it legitimized the affirmation of blackness in Brazil (Silva 1995; Telles 2006; de Santana Pinho 2010). The emergence and influence of afoxés and blocos-afro ${ }^{20}$ such as Bahia's Ilê Aiyê (the bloco-afro that only accepted very dark-skinned blacks as members) also contributed to the new conscience of blackness, which had been highly influenced by the U.S. Civil Rights Movement and Pan-Africanism.

Afro-Brazilians in the city of São Luis did not adopt Funk or Soul Music like their southeastern counterparts, but they began to informally and leisurely mobilize their communities using roots reggae music, which followed other forms of Caribbean music through maritime trade (see Silva 1995, Yawson 2016). With the influence of dance traditions such as forró, merengue, and bolero as discussed above, black populations in

\footnotetext{
${ }^{20}$ Street marching bands and Carnaval troupes/groups in Salvadar da Bahia
} 
the city's favelas $^{21}$ and periferias ${ }^{22}$ flocked to dance in pairs in open public surrounded by radiolas.

As I detail above, what the poor black population of São Luis in the periferias did was transform the style and sensibilities of roots reggae music and transformed it in their own dancing spaces. The creation and maintenance of music spaces created the need for a consistent production of roots reggae music that catered to specifically to the Maranhão market. As the California born DJ Sapato recounts in an interview:

"Roots reggae fanatics in this city are incredibly hard to please! You just can't play any tunes or tracks to get the crowd going. Basically, the random Marley tracks that will get your average American or Caribbean club audience going leaves this Maranhão aficionados with no reaction. It is so strange! See, first of all, the speed of these tracks made for this market have been slowed down to suit the dance rhythms of the ballroom style you see everywhere. And it is not just that the crowd down here, you know. The music, it's the music it needs to make sense to them. They know and only enjoy the vintage stuff. So you [the DJ] gotta know your stuff too".

As noted by DJ Sapato, because the reggaeir@s market required a particular type of roots reggae music, spaces that provided the music had to cater specifically to that need. Consequently, that market need opened up an economic market for many middle class vinyl collectors in the city. Businessmen and sound system owners began to import reggae music through commercial links in São Paulo. Eventually, locals started travelling abroad to buy records in London because the cost of flights to Jamaica were incredibly high but flights from São Paulo to the UK proved to be more profitable. Many of my interviewees recount how collectors who did not speak English would arrive at London's black record shops with tape recordings in imperfect English sentences, asking for particular records. As recounted by Riba Macedo who often embarked on these UK trips,

\footnotetext{
${ }^{21}$ slums

22 marginalized neighborhoods
} 
Jamaican artists in the UK produced a predominant portion of Jamaica's music in the 1960s and the 1970s. Comparatively, around the same time period, the Brazilian military regime enforced a domestic production of Brazilian music by banding imported records as well as instituting license laws that ensured that foreign music companies could only license their music through local Brazilian affiliates. Additional the military regime also bolstered the local music industry by providing financial stability of Brazilian labels such

as RGA, Ariola, Som Livre, Copacabana and Continental. As aforementioned, the lack of direct contact between Maranhão and Jamaica, especially via international flights and the state-sanctioned music licensing control made access to music directly from Jamaica almost non-existent. However, the music created by the Jamaican artist Jimmy Cliff in the 1960s and 1970s managed to evade this difficulty in access.

\section{The Impact and Influence of Jimmy Cliff and Johnny Nash's Artistry on São Luis' Roots Reggae Scene:}

As I have discussed earlier in this chapter, Caribbean music forms arrived in São Luis through the transnational connections in maritime trade and local informal music trade of the Southeast. These informal music trades came particularly from music labels and record distributors in São Paulo and Rio de Janeiro who employed radio stations in São Luis to play their music by distributing promotional copies of their new productions. Additionally, small business record collectors and small-scale sales representatives in São Luis also became outlets for music distribution through sales and informal trade. It worth noting that some of these music sale representatives also happened to be disc jockeys at Difusor AM, one of the prominent radio stations in São Luis. DJs, Edivaldo Assis and Zé Branco aided in the popularization of Jamaican records on their radio programs. The hits 
that these DJs popularized on the radio were then adopted by the sound system parties of that era. As noted by DJ Sapato above, the familiarity of Ludovincenses with what are deemed as obscure Jamaican tunes elsewhere outside of São Luis and by extension Maranhão, was as a result of the popularization of very particular tracks by the radio DJs who were sales representatives purposefully promoting particular tunes commercially from record labels from the Southeast

Moreover, the commercialization of made-for-television music festivals also helped to familiarize the working class population in São Luis with artists from various places (Tinhorão 1981). Amongst these was the then budding Jamaican artist, Jimmy Cliff, who competed in TV Globo's ${ }^{23}$ third Festival Internacional da Canção (International Song Festival) held in Rio de Janeiro in 1968, where he won the category for international artist for his performance of the his hit song, "Waterfall" (ibid.). The popularity of Jimmy Cliff's music happened within the context political censorship of Tropicalist music production that is worth noting: the songs of Tropical musicians such as Gilberto Gil, Geraldo Vandré and Caetano Veloso were often censored on these television music festival on TV Globo and TV Record for protesting or inciting revolutions against the then military government of Brazil. At the end of 1968, the military government imprisoned these musicians for their work, however their oppositional work in their music incited a wave of popular protests against the military government (Dunn, 2001).

In retaliation to these protests, the military government enacted Institutional Act No. 5 to suppress and oppress the works of various artists, musicians and intellectuals that

23 One of Brazil's major television network 
opposed it. Many of these artists were exiled, killed or excommunicated from their communities (ibid.) According to Dunn (2001), Jimmy Cliff who interacted often these Tropicalist musicians at the Sucata nightclub in Rio de Janeiro was heavily impacted by their friendship and artistry that he often stayed for long periods of times to work. In 1969, Cliff is acclaimed to have written his first international hit song "Wonderful World, Beautiful People" (see Photo 19 below) alongside other hits such as "Vietnam", "Many Rivers to Cross" amongst others in Brazil's political censorship climate (ibid.). The success of Cliff's albums in the UK and in the US promoted Philipp's owned Brazilian label to release Cliff's LP, entitled The Greatest Hits that featured songs like "Wild World" and "Waterfall", which Cliff had previously performed in São Paulo the previous year (Dunn 2001). To promote Cliff's album in Brazil, the label chose for the cover the colorful picture of Cliff A\&M 1970 album with the "black liberation" colors and on the back a picture of him on a motorcycle, to feed into the then craze surrounding rock and roll genre.

\section{Photo 19-20: Jimmy Cliff Wonderful Album}




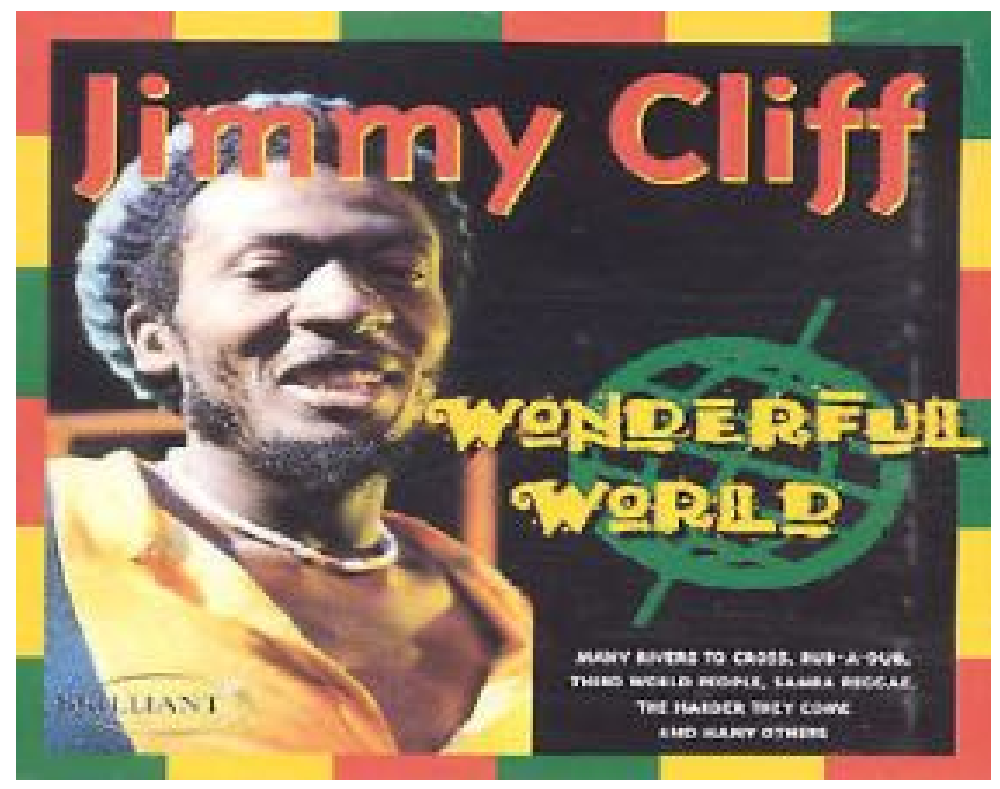

Photo 19

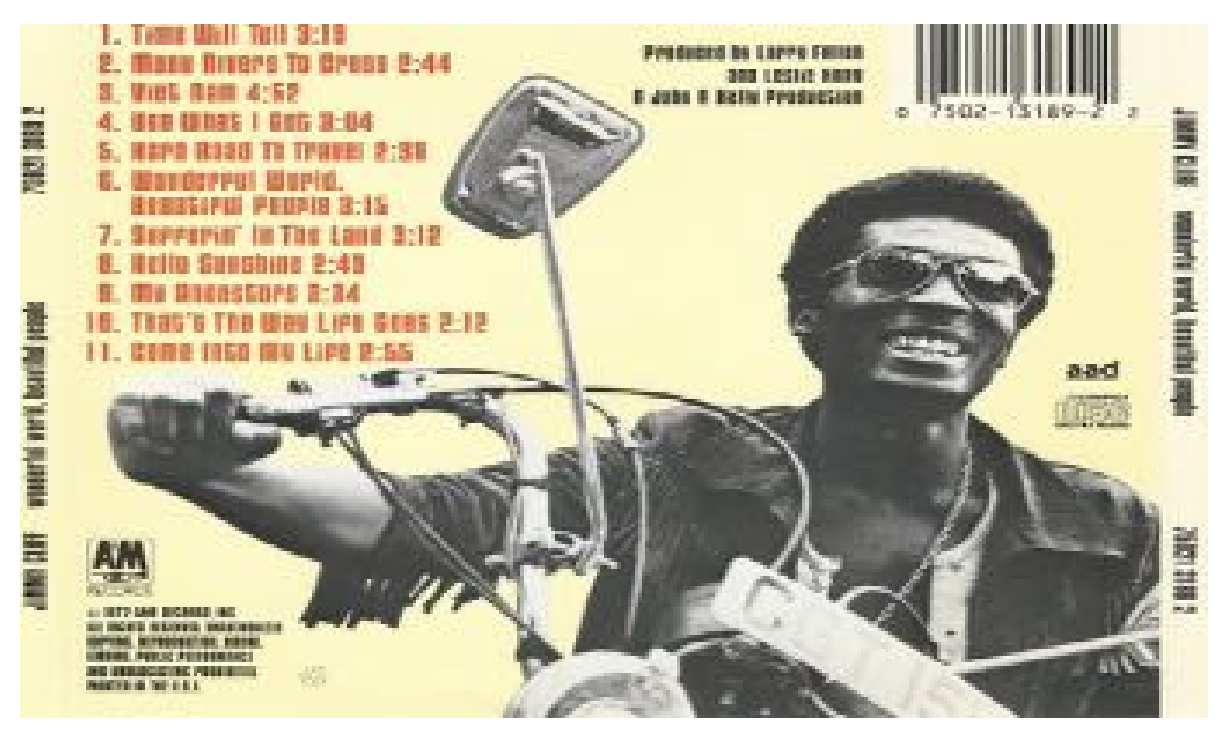

Photo 20

The launch of this album was incredibly successful; in São Luis, the LP was widely played by major radio stations and it was popular among music collectors who fondly referred to the album as the disco da moto (the motorcycle album. See Photo 20 above) in reference to strategically commercialized photograph of Jimmy's Cliff's on the 
back on the album. In general Cliff's LP was welcomed into Brazil's then music scene that was inundated with rock and roll as well as international pop music. In fact, Jimmy Cliff's artistry was so influential that the 1960s Brazilian jovem guarda or $i \hat{e}-i \hat{e}-i \hat{e}^{24}$ bands in the likes of the Fevers recorded a cover of Cliff's "Suffering in the Land" in Portuguese called "Sinto mas Não Sei Dizer" (“I Feel but I Don’t Know How to Say It") that was written by Rossini Pinto. Due to Cliff's influence, for the first time in Brazil's music history a reciprocal transnational connection between Brazil and Jamaica was created; Cliff's music was impacted by Brazil's political censorship, and Brazil's jovem guarda music was influenced by Cliff's music and later on with Tropicalist musicians as well.

Interestingly, the musical connection that Cliff's LP had created only spurred a gradual influx of other Jamaican music and artists. In 1971, the Brazilian label launched Dave and Ansel Collins "Double Barrel" and it became immensely successful in São Luis (De Koning and Griffiths, 2003). This was followed by São Paulo's record label Discos Beverly re-release of Jimmy Cliff "Let Your Yeah be Yeah, and Dave and Ansel's "Monkey Spanner". Later in 1974, Discos Beverly also released several tracks by various Jamaican bands, namely, The Ronettes, Daisy Duke and the Maytals' "Monkey Man", which was a hit in São Luis as recollected São Luis music collector Aplonisio Paulo de Sá Filho, also known as Paulo Caribe:

When I say "Monkey Man" was a success, I mean that the track was very popular or it has a huge commercial success. I mean every club in the

\footnotetext{
24 jovem guardo or $i \hat{e}-i \hat{e}-i \hat{e}$ (Portuguese cognate for the "yeah, yeah, yeah) bands were popular bands of the late 60s and early 70s that mimicked the likes of British and American rock and roll bands such as the Beatles. They remade Brazilian versions of international hit songs in Portuguese.
} 
periferia, in the city, in households, you know... You heard it played consistently on the radio, in the parties and things like that. There are no charts doing a countdown or competition of what songs are best but you just knew when a song was a hit. You heard it more than enough times to know.

As noted by my interviewee, Paulo Caribe, Jamaican music of the 1970s became successful in São Luis if they managed to get a great deal of exposure or airtime on radios and in reggae dance spaces. Consequently, record labels consistently found ways to push out new albums by marketing them in ways that would get them more airplay time. I mentioned earlier in this chapter that the popularization of roots reggae music coincided with American Black Soul Movement that was adopted by many black communities in the Northeast as well the black migrant population that moved to Brazilian cities like Rio de Janeiro and São Paulo at the heights of its Southern regional industrialization. Taking advantage of the impact of the Black Soul Movement, the record label Discos Beverly in São Paulo released collection of LP entitled "USA Click", which they marketed with the image of the flag of the US on its cover. Although the LP featured a few American rock and roll and "black soul" hits, the record label snuck several Jamaican reggae songs onto the LP. This included, Bob and Marcia's “We've Got to Get Ourselves Together, Dandy's "You're Coming Back", Horace Faith's "Black Pearl”, and The Upsetters' "Shocks of A Mighty".

In 1972, the record label Copacabana released a reggae-rhythmed LP that was produced by several musicians based in Los Angeles. The LP, entitled "L.A. Reggae" (see photo 21 below) included a variety of international hits, however, the AfricanAmerican musician, Johnny Nash's “I Can See Clearly Now” was a tremendous success 
in São Luis. Following this success, music collectors in São Luis began in search for other Johnny Nash records. In Kingston Jamaica in 1968, prior to the release of "I Can See Clearly Now", Neville Willoughby, a novelist had introduced Johnny Nash to the then local struggling group, “The Wailers”, whose members included Bob Marley, Bunny Wailer and Peter Tosh (www.worldareggae.com retrieved September $4^{\text {th }}$ 2015). The Wailers introduced Nash to the local reggae scene in Kingston, and Nash then signed all three members of the Wailers to an exclusive publishing and recording contract on his JAD label with Danny Sims in New York City. In 1971, Nash worked closely with Bob Marley and Fred Jordan as co-composers in the Swedish romance movie "Vill Sã Gärna Tro", of which the film's soundtrack featured partly instrumental reggae with strings. In November 1972, Nash also worked together with Peter Tosh and Bob Marley on several records (ibid.). Nash released "Bend Down Low" in 1968 and "Reggae on Broadway" in November 1972 on the same sessions that he recorded "I Can See Clearly Now" on in London with Peter Tosh, which sold millions of copies and won a gold disc R.I.A.A. award. In 1977, Nash released an LP “Johnny Nash, reggae collection (see photo 22 below), which featured four of Bob Marley's original compositions published by his label JAD, "Stir it up", "Guava Jelly", "Comma Comma" and "You Poured Sugar on Me" that was co-written by both Nash and Marley (ibid.). 


\section{Photos 21-22: Johnny Nash's LP “L.A. Reggae”}

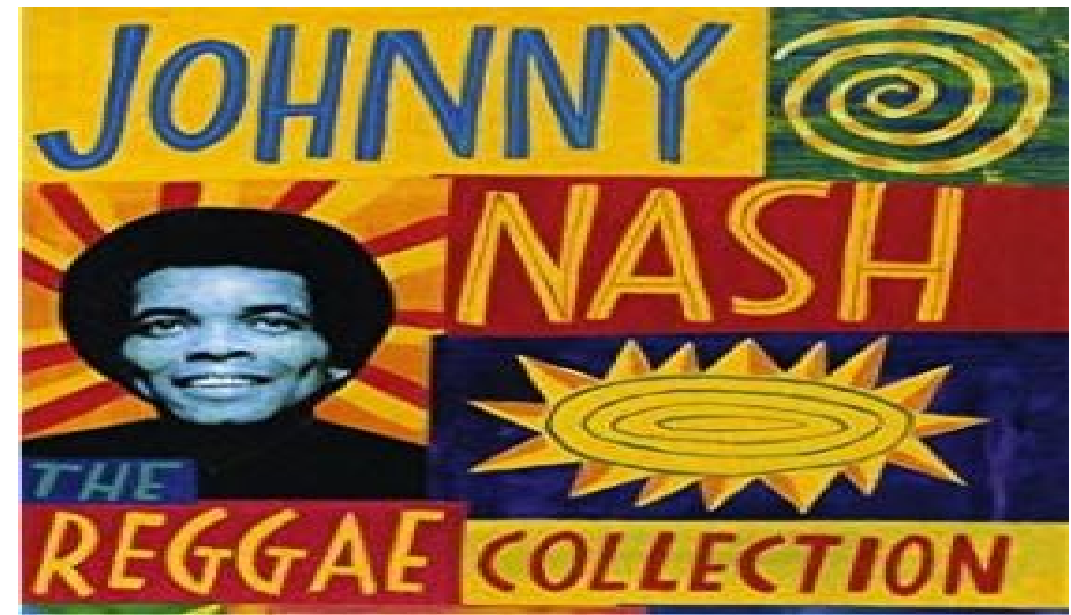

\section{Photo 21}

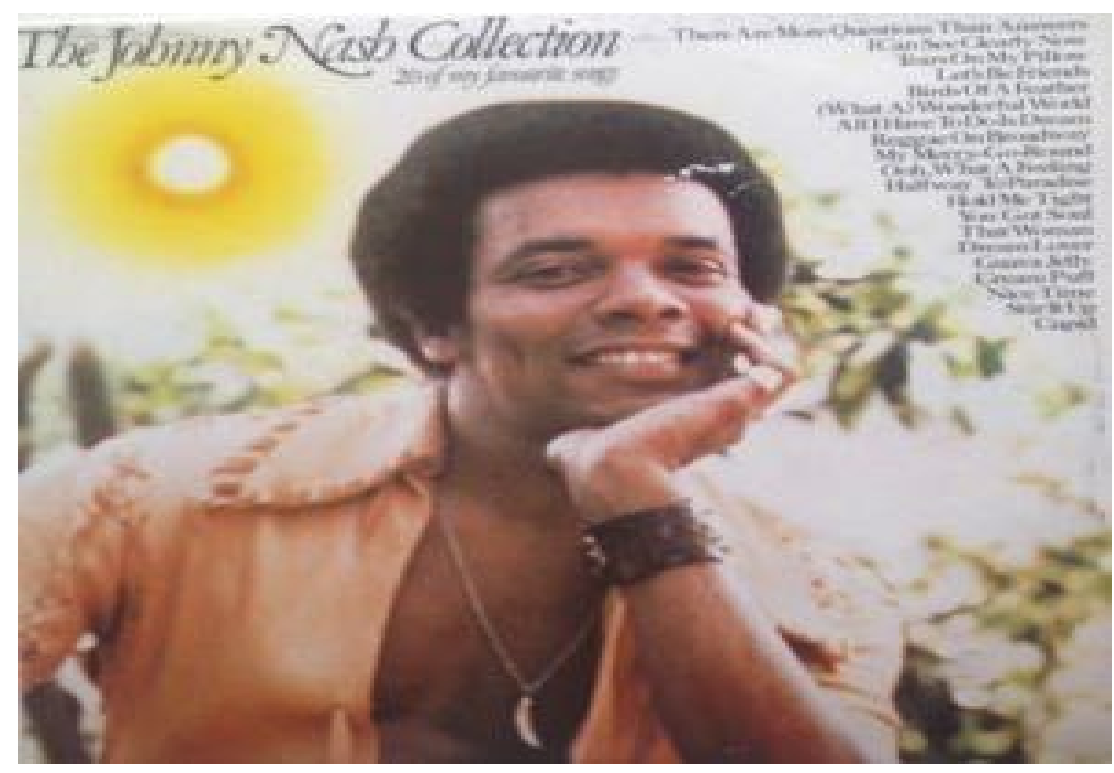

Photo 22

The same year, the record label, Epic Records launched Nash's LP "Johnny Nash, reggae collection" in Brazil, and the release took off immensely in São Luis. The tracks, "You Poured Sugar on Me", "Stir it Up" and "Guava Jelly" became household songs in Maranhão in general. These hits from Marley formed the foundations for the success or failure of subsequent international music in São Luis. This is particularly evidenced in the 
success of songs that incorporate the elements of guitar skank, beat, bass-line and swinging tempos of Jamaican rocksteady and early roots reggae. For instance, nonreggae songs such as Sharif Dean's "In the Sumer Holidays", Orleans' "If" and other singles from the UK and the US have been transformed rhythmically to incorporate these elements and have done incredibly well in São Luis because of that reason. Moreover, in 1973 and the following years, singles such as Nolan Porter's cover of the Kingstonians' rocksteady classic, “Singer Man”, Eric Clapton’s cover of Bob Marley and the Wailer's "I Shot the Sheriff, The Rollings Stones' and cover of Eric Donaldson's 'Cherry Oh Baby" have been hit records in São Luis until this day. ${ }^{25}$

\section{0s Brazilian Military Censorship of Reggae Music and its Impacts on São Luis:}

My discussion of this portion of the dissertation ties into my arguments in the more theoretical chapters of this work, that suggest that the performative spaces of reggaeir@s in São Luis should be seen as divergent from all others in the Afrodiasporic spaces going through processes of statist multiculturalist policies. This is because in assessing the historiography of the trajectorial development of the roots reggae scene in São Luis, especially at the heights of the globalization of reggae music, it becomes evident that the global circuits of reggae music were obstructed by the Brazilian Military government's censorship. This extremity of this censorship was vastly immense such that the performative spaces of reggaeir@s in São were not influenced by the "Marleyism" and Rastafarianism or the political scene of Jamaica as other spaces around the world were been impacted.

25 DJ Jorge Black, interview by author, Centro Historico, March $15^{\text {th }} 2016$ 
In the early 1970s with the release of its first two feature films: "The Harder They Come" with Jimmy Cliff in the lead role as a gangster pushing back against Jamaica's oppressive state system; and "Catch a Fire” featuring Bob Marley and the Wailers' politically stringent lyrics in "Slave Driver", "Catch A Fire”, “Concrete Jungle” and "400 Years", Jamaican reggae music came to be perceived through the global circuits as the sounds of revolution and rhythms of outlaws. Considering how the music of Jimmy Cliff and Johnny Nash had influenced São Luis' reggae scene, one would expect that these feature films and music would have also been received well in São Luis. However, the censorship of Brazil's military government interfered with this process. For instance, the Cliff's feature film, "The Harder They come" was censored in Brazil, and so it was never played in theatres anywhere in the nation. Moreover, like Cliff's feature film, the military government also restricted the way in which Bob Marley and The Wailers single, "Catch A Fire", was released. The album, which originally featured Marley on the cover smoking a humongous marijuana cigarette, was launched in Brazil. As DJ W. recounted to me in an interview:

Those fools during the military government did a lot, you know. I know they blocked "Catch A Fire" because of the marijuana. But music here is not about marijuana. When I think of these things sometimes I don't know what to think, imagine. We dance agarradinho here to roots, here, it's about happiness. Anyway, back to my original point. So when "Catch A Fire" finally came here, to Brazil, they just wrapped it in a blank album cover. My sister, in a blank white cover, can you imagine that? They did everything to prevent from us getting our roots but look at things now. We were still able to build our own Jamaica in Brazil. (DJ W, Interview in his studio at Rádio Mirante FM, May 2016).

DJ W.'s account was corroborated by many other interviewees who also affirmed that after "Catch A Fire" was finally released, it did poorly in the performance spaces of reggaeir@s in São Luis. Their accounts also suggested that the restrictions that came with 
the release of singles like "Catch A Fire" (see photo 23 below) and "Kaya" in 1974 (see photo 25 below) was also accompanied with an intentional state-sanctioned suppression of the political information and the "outlaw" messages or revolutionary discourse that reggae music transmitted through the global circuits of music using Rastafarianism or black liberation rhetoric. As recounted by Biné the president of Agrucorem-Associação de grupo do colecionador reggae (The Association for reggae music collectors in 2011), the single "Kaya" went through a very similar censorship as "Catch A Fire":

The Single "Kaya" was obviously a brother to "Catch A Fire". The both spit "Fire" lyrics. Interesting that I choose to describe the lyrics as fire, you know [he giggles]. It was fire, you know. Fire to the government. The Marijuana on the cover was fire, the lyrics in the song was fire, the rhythms were fire, the ideas were fire, the revolution was fire, they were all fire, fire, fire to the government. So why would they allow it in Brazil without hiding it? They [military government] just didn't want the masses learning that reggae is often associated with marijuana, and maybe it worked because marijuana was not a big problem or popular here [referring to São Luis) around that time like Rio or Sampa [referring to São Paulo]. It is difficult to get things here on our island anyway. (Interview with author at an Agrucorem meeting in São Francisco periferia in June 2011). 
Photos 23-24: Bob Marley and the Wailers' "Catch A Fire" album cover, Jimmy Cliff's Movie, "The Harder They Come"

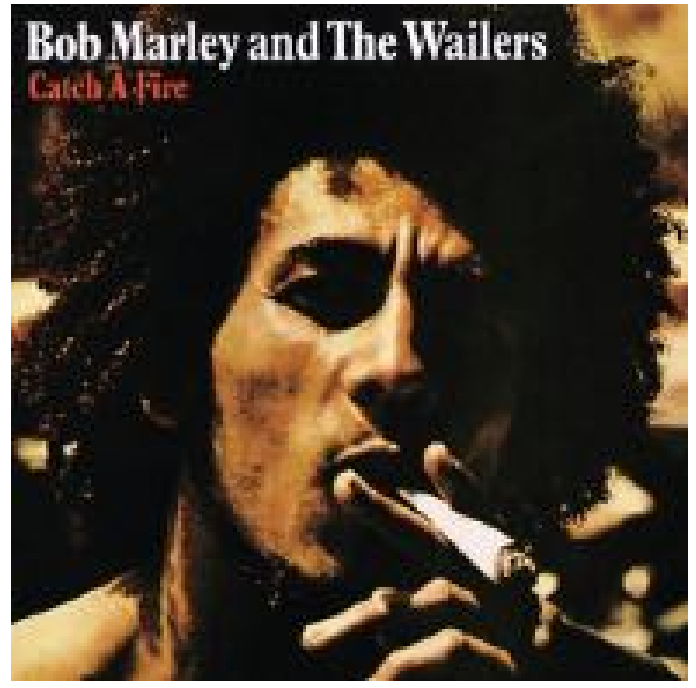

Photo 23






\section{Photo 25: Bob Marley and the Wailers Album "Kaya"}
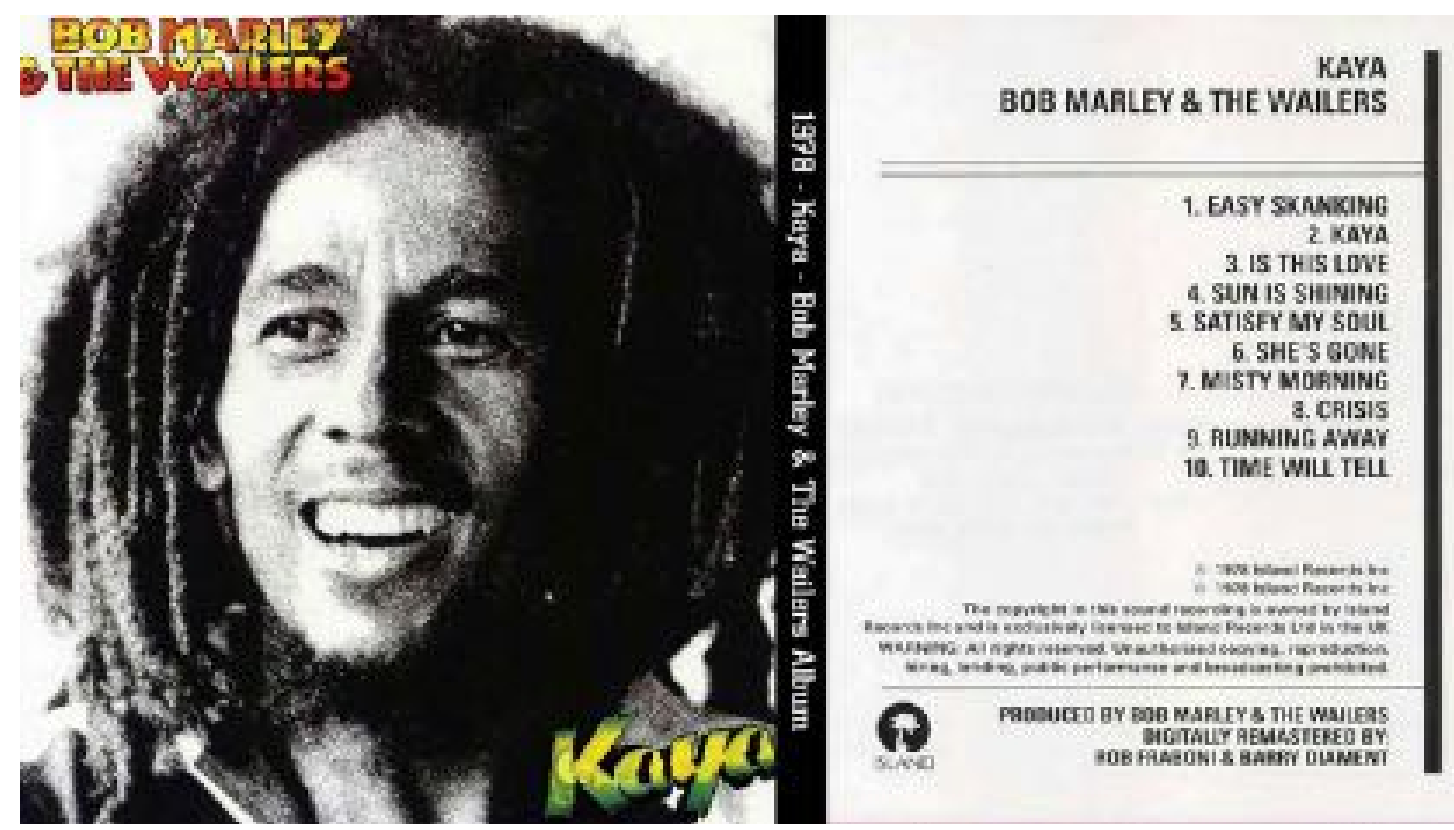

Photo 25

Many other interviewees, especially from the Agrucorem group, and radiola and club owners knowledgeable about this history gave similar accounts. As discussed by Chang and Chen (1995), Potash (1997) and Katz (2003) the two aforementioned feature films were paramount in the globalization of reggae music and its associated symbolisms (This includes but not limited to the idealization of Rastafarianism, use of Marijuana, dreadlocks, use of black liberation colors and the image of Bob Marley in general). So then if by virtue of the Brazilian military government censorships, the factors that popularized reggae music were suppressed in the city of São Luis (and Maranhão) then what can be deduced from my interviewee accounts is that Ludovicenses and Maranheses related to reggae music differently than the rest of the globe. From these same accounts 
and as noted early in this chapter concerning the genealogy of black popular music as a whole, the general consensus is that the black population in São Luis were not aware of the genre of "reggae" as it was known elsewhere but they identified with it as "international" music, just like the cumbias, boleros, compas, merengue and the like that were first introduced on the island. Instead, most people at that time referred to the "international" category as "Jimmy Cliff".

The association of the genre reggae with Jimmy Cliff speaks to how the censorship of "The Harder They Come" did not alter the celebrity and impact that Cliff had already achieved in São Luis prior to the release of this feature film. In succeeding years following the censorship, more of his albums were launched and vastly broadcasted on radio stations throughout Brazil and São Luis. Cliff's fame and impact continued well into the decade in the 1970s; after the record label EMI-Odeon in São Paulo launched his "Unlimited" album in Brazil, the record label Phonogram followed it with Cliff's LP, "Struggling Man", where the lyrics of each song on the LP was translated into Portuguese together with the English version. With the release of other LPs such as "House of Exile", "Unlimited", "Follow My Mind" was lauded as Cliff as one of the most influential international artist in Brazil on EMI-EMC-3035 LP 1974 album liner notes.

As a matter of fact, Cliff had gained an exceptional superstardom to point that by the turn of the decade, every radiola owner sought after his albums to ensure that their parties were popular. As Silva (1995) notes, Cliff's fashion style and way of accessorizing with necklaces became the a-la-mode for many young black men in the periferias. Silva notes that in São Luis it became the nickname "Jimmy Cliff" of the day for young black men who could mimic Cliff's sense of style very well, and so every 
periferia had several people nicknamed as such. My interviewee, A.S., who selfidentifies as a reggaeiro, recollects listening to all sorts of reggae music alongside other genres such as pop, soul and rock and roll that were all entitled "Jimmy Cliff" or "international music" at various radiola parties. He also notes that in the 1970s, his favorite, Eric Clapton's “I Shot The Sheriff” were played frequently by radio host Jota Kerly, and Florisvaldo de Sousa on the radio program Parada dos Astros. These radio hosts did not reference these songs as reggae but as "musica internacional".

Lastly, the language barrier in terms of the English lyrics of reggae music for most Maranhese also contributed to how reggae impacted Ludovicenses differently than elsewhere in the world. For the most part, the vast majority of people in São Luis do not speak English, and so the lyrics of pop, soul, rock and roll and other musical forms that were introduced in São Luis were all incomprehensible to most listeners and dancers. Besides, because all of these musical forms that came through the heightened global circuits of the 1970s were categorized as "international" music that were all recorded in the English language, Ludovicenses did not differentiate between what was reggae music and what was not. As such, for the average working class inhabitant of the periferia attending radiola music and dance events, there was no difference between Motown tracks, British pop albums and the Jamaican rhythm sounds of reggae or ska or rocksteady albums. Additionally, because most global artist often borrowed, re-recorded songs across the globe, Brazilian record labels often found it feasible to commercially sell records that contained all of the various hits from different genres. This resulted in music audiences in São Luis receiving an amalgamated genre of all sorts of hits songs that did not make reggae music particularly stand out. 


\section{Exceptionalizing Roots Reggae: How the focus of "Musica Internacional" Shifted to}

\section{Roots Reggae Music in São Luis:}

According to my interviews with DJ JB and Professor Carlos Benedito da Silva, following the popularization of "international music" in São Luis, especially due to the celebrity of Jimmy Cliff, Ludovicenses in the periferias began to expand the ways they accessed these forms of music outside of the usual radiola dance events. In the late 1970s, many started to buy albums for themselves. This created a disadvantageous business competition for radiola owners who organized these music and dance event. On the upside, the access to albums increased the appetite of Ludovicenses for different forms of "international music", which created the demand for radiola owners and music and event planners to diversify their music collection. What then differentiated one radiola from the other competitively was any one soundsystem having access to quality exclusive songs that they could play at their events that the next soundsystem did not have. With these forms of competition in mind, the business of soundsystem entrepreneurship diversified with equipment upgrades. Radiola owners invested in larger amplifiers, and additional speakers in attempts to outdo their next competition. The advancement in soundsystem amplifiers provided more powerful and crispier sounds at music and dance events.

Coincidentally, the development of soundsystem technology and business in Maranhão occurred independently at the same time as that of Jamaica's soundsystems. São Luis' now advanced radiola systems became well equipped for the newly developed wave of Jamaican reggae that was characterized by sharply defined treble sounds, 
syncopated bass rhythms and clearly defined sound frequencies (Chang and Chen, 1995; Potash, 1997; Katz 2003; Cooper 1993, 2004). It is around the same time that the Brazilian record label released Bob Marley and the Wailer's album “This is Reggae Music", which had originally been licensed to various major global markets to popularize the genre of reggae following its success in the US in the late 1970s. In São Luis, record collectors found this LP to be very popular and others like it, and so it compelled other record labels to launch other LP's like it. In response, the record label Brasidisc Gravações launched the LPs "Roots Rock Reggae" and "The Front Line". The record label Beverly also launched three follow-up volumes of "This is Reggae Music".

According to Silvio from the collectors group, "Quarentões do Roots", the first time Ludovicenses heard of the term or genre name "reggae" was when record labels in advertising the new wave of reggae LPs in Brazil employed journalists and music aficionados from São Paulo to descriptively write on the records, in newspapers, journals and elsewhere about the reggae music. Journalists Julio Barroso and Otávio Rodrigues became two very significant writers that promoted reggae music in Brazil with their descriptions of "The Front Line" and "Roots Rock Reggae" respectively. Their jobs entailed advertising the new wave of the lover's rock style of reggae then popular in Jamaica, and also introducing popular artists around the world that recorded this style of music. Barroso and Rodrigues' work inspired collectors in São Luis to develop business relationships with record labels and to travel to the UK in search of this "new" genre of music for their collections.

With the popularity of reggae music on the dance floors in São Luis, Ludovicense DJ's played them in conjunction with other genres such as disco. In the periferias, disco 
became known as "musica internacional rápido" (fast international music). Moreover, with the release of "Célimène" by the Martinican artist, David Martial in São Luis, dance spaces played the faster rhythms of zouk, merengue, Carimbó (from the Brazilian State of Pará) and lambada, which as discussed above had been Maranhão's adaptation to various forms of Caribbean sounds and rhythms. The addition of roots reggae, another Caribbean sound, fit well into to the collection of "international music" played on the dance floors in São Luis. By 1978, hits like "Rasta Soul Reggae", "Blue Reggae Band” and "Harlem Reggae" etc. made their way onto the dance floors in São Luis. By the 1980s, more reggae songs from other parts of the world beside the Caribbean had infiltrated São Luis' dance floors as well; British reggae band, Black Slate's "Amigo" and "Reggae Everytime", reggae covers such as Bernie Lyon's version of "Eleanor Rigby" and T. Brothers' versions of other Motown hits were crowd favorites, as recounted by DJ W..

The interesting part of what was happening in São Luis with reggae music was that songs and their associated artists that became hits in Jamaica were not even popular in São Luis and vice versa. This meant that imported records from elsewhere outside of Jamaica had to be the source of supply for the obscure popular music selections on the dance floors of São Luis. Consequently, São Luis' musical preferences in reggae developed on the peripherally from the global circuits of mainstream reggae music that embraced Rastafarianism conjointly with reggae as a genre. The focus on roots reggae in São Luis then became strictly associated with the rhythms of reggae and its compatibility with pre-existing embraced ballroom styles of dancing on the island. By the end of the decade, when radiola owners began to specifically look reggae albums from Jamaica, the black population of São Luis' periferias had already syncretized the rhythms of the 
Caribbean dance styles on the island with the new form of "international music", which was now roots reggae.

\section{Dancing Agarradinho:}

Throughout my research when I asked interviewees how dancing in pairs in the

ballroom style to reggae music started, they would always mention how Ludovicenses ${ }^{26}$ have always danced to popular music that was not reggae ${ }^{27}$. From these interviews, I gathered that because working black people in São Luis have always danced to a variety of Caribbean music forms that was collectively labeled as "international" music (as I have discussed earlier in this chapter), dancing ballroom style to reggae music was not an ideological innovation but a practical one. As I discussed earlier, when the Caribbean music style switched from "merengue" (which were a hybrid of various Caribbean forms), to reggae during the heights of the Brazilian Black Social Movements, the music form changed but the way to dance to them remained the same (Turner and Rodrigues 2007).

The question then remains as to how and when agarrado dancing became strictly known as a reggae dance style. My argument here is that because blacks in São Luis had already adopted a hybrid of Caribbean dance styles, these styles interacted and were synchronized on the dance floor with new forms of music as they were introduced. Moreover, with the purposeful promotion of roots reggae by Brazilian record labels, the advancement in the technology of soundsystems, and the inception of the black social movement, black ludovicenses created and recreated dance styles that were well suited

\footnotetext{
26 Inhabitants of São Luis do Maranhão

27 see my discussion on the adaption of Caribbean musical forms above
} 
for the rhythms of reggae derivatively from previous styles by assimilating the old bodily movements to suit the new rhythms of roots reggae.

Writing about the evolution and genealogy of music and dance traditions often to prove to be a tasking one because these events are not necessarily recorded or archived somewhere. And because I had to rely heavily on the accounts of interviewees, especially ones that would often give conflicting narratives about the same events, my conclusions about the evolution of agarrado dancing is deductive based on all of the sources I gathered throughout this research. As I mentioned earlier, at the turn of the decade from the 1970s into the early 1980s, the dance spaces in the periferias of São Luis were inundated with a variety of "international" musical forms. Consequently new music and new rhythms that were introduced through time required the modification of bodily movements to suit the syncopations of the bass line of the new rhythm introduced on the dance floor. As recounted by several interviewees, in the late 1970s when reggae arrived on the dance floors, DJs had follow a particular sequence of songs with regard to popularity to satisfy the crowd and dancers. DJ NG mentioned that the crowd back then preferred the faster paced rhythms of jovem guarda followed by disco, pop and rock and roll respectively. Every once in a while the DJ would insert a slower pace rhythm to give the dancers a rest in between the usual sequences. This created the perfect opportunity for the DJ to insert slower-paced reggae songs for that exact purpose. Dancers who were already familiar with the ballroom style of merengues, boleros, cumbias, compas and other Caribbean forms instinctively drew on these styles to dance in couples.

The soundscape of roots reggae in São Luis caters specifically to the dance moves as it has been developed in the dance spaces. The Jamaican reggae of the 1970s that was 
introduced in São Luis was a slower version of the style rocksteady, which was also an even slower version of ska. Although the reggae of the 1970s was not as fast as the merengue that Ludovicenses were used to, or slower than the bolero, its rhythms were well adapted to the dance floor routines then. The bass line and sonic rhythms of the lover's rock style of reggae had been technologically modified to suit the pace of the dance. Hence, the pace of the beat in São Luis' reggae music has been incredibly slowed down in comparison to the reggae that one would hear in the Caribbean or elsewhere. According, the record collector Riba Macedo, the pace of reggae at that time was not that much different from the northeastern styles of xote, cumbia and forró. He added that dancers innovated but only in the sense that couple dancers had to pull closer in more of an embrace style than they would with the styles of merengue or bolero.

Descriptively, the dance agarrado or agarradinho ${ }^{28}$ is a ballroom dance style to the lover's rocksteady form of reggae music that resembles the dancing style of zouk, merengue, and forró, and to a certain extent bolero from my perspective as a trained dancer. However, the latest versions of the dance these days greatly resembles Angolan kizomba, especially in its version as electronic reggae or robozinho as it is known locally that was developed to suit the incorporation of hip-hop and pop movements by the youth of São Luis today. My interviewee, LM from the periferia of Liberdade and BB of the periferia Olho D'água, both grew up in the 1970s dancing and attending radiola events. The both gave accounts that corroborated agarradinho dancing as in fact a

\footnotetext{
${ }^{28}$ I use the term agarrado and agarrad[inho] interchangeably, with an emphasis on Brazilian Portuguese "-inho" to not only show the level of endearment of the dance to reggaeir@s but also to the author, the message of strength codified in the performance of the body that appears delicate and fragile at the same time
} 
hybrid of forró, bolero, merengue and lambada, and as noted by Daniel (2011) all of these dances were all developed in the Caribbean and Latin American region in accordance with national discursive ideologies about African-based rhythms and European dancing styles that are not distinctive from their composite forms. Accordingly, Fryer (2000) and Chasteen (2004) assert that most black popular music and dance traditions in Latin America are unique products of syncretization of African beats and rhythms and European dance styles.

Agarradinho is syncretized in the sense of its derivation from other styles that are also hybridized, making agarradhinho even more complexly hybridized in its performance. Most of the dances from which agarradinho is derived are danced in three bodily sways to each side of the dancer with alternating footwork that pauses on the fourth beat of the rhythms of the music. Conversely, dancers agarradinho[ing] to roots reggae in São Luis dance to the bass line of the reggae song as opposed to the entire rhythm that is made up of the percussion, bass and tempo of the keyboard. However, as described by DJ Black, because the rhythms of roots reggae's bass lines of the 1970s are highly syncopated, the intricacies of its rhythms do not leave much room dancers to a loose sway side to side like for instance a bolero move. Instead, dancers transformed it to a more tightly embraced swing that mainly follows the baseline. As I mentioned earlier, the pace of roots reggae produced for São Luis had been transformed to sustain the radiola's new electronic technology, and so in that effort, the bass guitar and kick drum sounds formed the determinative style of the bodily movements in agarradinho. 
Because I have written extensively elsewhere about agarradinho dance itself, the interactions of dancers on the dance floor and its significance (see Yawson 2017), I will not be focusing on dance style itself in this dissertation. However, because the roles the performative spaces of reggaeir@s in dialogue with statist discourses of hybridity and citizenship are at the center of this work, detailed illustrations of the intricacies of the dance are discussed in the ethnographic portions of this project. Altogether, the discussions of this chapter have focused on various historiographies that has contributed to the production of roots reggae music and dance culture in São Luis do Maranhão. In the next chapter, I engage in theoretical discussions of statist discourse and its practical implications on how music and dance practices are lived and experienced in reggaeir@, performatives in São Luis. 


\section{Chapter 3: "Democraçia Racial": Navigating Statist Discourse and the Criminalization of Reggaeir@ Space and Bodies}

At the beginning of this dissertation, I suggested to the reader to attempt to set aside any preconceived notions about roots reggae music and the dancehall scene as it pertains to the Caribbean, particularly as seen in Jamaica in order get an in-depth understanding of reggaeir@ culture. However, at this juncture, I would like to briefly draw the reader's attention to a peculiar Jamaican reggae performanscape - the plot of the 1972 Jamaican film, “The Harder They Come". This film features the Jamaican artist Jimmy Cliff, whose artistry arguably heavily impacted São Luis’ reggae scene (see Chapter 2). In this film, the artist Jimmy Cliff plays a character named Ivanhoe "Rhyging" Martin, who migrates to the capital city of Kingston from an impoverished rural area in Jamaica in search of a better future. While attempting to make a life for himself in Kingston, Cliff's character Ivanhoe, becomes immersed in Kingston's complicated reggae music scene that is also inundated with urban-life criminality. Although Ivanhoe manages to create a hit reggae record, the intricacies of his laced life of crime and violence cyclically keeps him trapped in the impoverished ghettos of Kingston. As the plot of the film evolves, Ivanhoe eventually becomes a reggae superstar and a celebrated icon in Kingston. However, at the end the film, the police kill him in a broad daylight shootout on the beach as he attempts to escape.

As Thomas (2004) recounts, Jamaican society and black dancehall musical practices have been always been defined by its relationship to crime and poverty. And as this film showcases, the evolution of reggae musical practices in Kingston has not been exempt from these linkages with criminality. I draw the reader's attention to this film for 
the following analogical reasons: My research from the archives of the Roots Reggae Museum in São Luis indicate that there had not been direct connections between Jamaica and São Luis in the 70s and most significantly, the film The Harder They Come had not been available to the Brazilian consumer market or reggaeir@s for that matter until the late 1980s. Yet, the narratives of many reggaeir@s as recounted in personal interviews demonstrate a discursive construction of reggaeir@ performanscape that is shaped by violence and intimately linked with crime in ways that are interestingly similar to life of the character Ivanhoe in this Jamaican film.

During an interview, Carlos Benedito da Silva, a resident anthropologist on reggaeir@ culture at the Federal University of Maranhão, stated that as part of the development of what he termed as the "culture of leisure" of reggaeir@ismo, reggaeir@s did not only borrow and transform roots reggae music but also borrowed the aesthetical ideas about reggae culture that were performative. This he asserts, were not limited to clothing style, hairstyles, language, and general performative demeanor or worldview. Silva stated that this was particularly true of the mimicking of the persona of popular Caribbean artists such as Jimmy Cliff whose music became incredibly impactful in the development of reggaeir@ culture.

Silva commented on the fact that at some point in mid 1970s every impoverished black neighborhood or periferia in São Luis had its own residential "Jimmy Cliff'. He described these "Jimmy Cliffs" as reggaeir@ young men whose choice in clothing style impersonated the dressing of the real Jamaican artist as seen on the covers of his albums or on television. As Silva notes to me: 
“...it was as if these young kids went out of their way to play dress up every day, except that it wasn't dress up, you know. They believed in what they were doing. You know, it's not like someone dressing up as Elvis Presley or James Brown for a fancy party. These boys lived and breathed a sort of "Jimmy Cliffism". Because back then the ultimate idea of who a reggaeir@ was, was what Jimmy Cliff the artist embodied. Or in other words, they defined this culture in clothing using Jimmy Cliff as an idol or symbol of roots reggae".

By Silva's account some of these "Jimmy Cliffs' went as far as living the Jamaican "rudebwoy" lifestyle as defined by the reggae artist. As defined by Thomas (2004) this meant the embodiment of identity expressions that "combined racial protest with a class-antagonistic morality among militant poor black men" that was performed in clothing style, street-smartness and violence (72).

Coincidentally, in the decade prior to the release of the film, The Harder They Come, the engagement of young reggaeir@s in their own versions of the "rudebwoy" lifestyle, following after the real life artist Jimmy Cliff just so happened to have eerily parodied the lifestyle of the "rudebwoy" character Ivanhoe in the film itself a decade later. Accordingly, statist discursive construction of the reggaeir@ identity by local elites in São Luis as I found in my legal archival research, appear to have coopted particular crafted perceptions of the "rudebwoy". These discursive notions about the "rudebwoy" are ones which identify the reggaeir@ identity is that of black musical performance of crime and violence. As shown in the archival records retrieved in my research, this discursive portrayal of reggaeir@ismo as a lifestyle of crime and violence appears to have been a deliberate propagandist media attempt by the elite in order to justify its heavily policing of the reggaeir@ performative space.

I begin this next section of the dissertation with a vignette that will direct my genealogic discussion of specific accounts of statist documentary practices (i.e. the 
implementation of laws in practice) that support my assertion of purposeful actions that have been used to garner support for the violent policing of reggaeir@s.



Photograph: Mugshot of Francisco das Chagas Costa Rodrigues, infamously known as "Jimmy Cliff"

The above photograph is a feature from the crime announcement page of newspaper Jornal Pequeno on January $23^{\text {rd }}$, 1981. The headline featuring this article is as follows: "Police Officers found the Vagabond/bandit, "Jimmy Cliff"”. The short article that follows the photograph states:

After subsequent searches the policia militar in the second Police Municipality District has been successful in arresting and putting into custody the lowlife Francisco das Chagas, infamously known as Jimmy Cliff. A vagabond/bandit who has been at large for a while now. He is notoriously known for the various armed robbery, physical assaults and invasions of many homes in the periferia Joao Paulo. Jimmy Cliff will most likely be transported within the next few hours to Department for Thefts and Assault, where he will be interrogated to further investigate the work of this vagabond. [Agentes Localizam o Lunfa "Jimmy Cliff" $O$ imparcial, January 23, 1981)

The person featured in this news article is Francisco das Chagas Costa Rodrigues, the resident "Jimmy Cliff" of Joao Paulo periferia. In the 1980s news articles like this one only featured news about the reggaeir@space in the crime section of the newspapers, 
and the goals of such news were aimed at attaching a face or a body to the reggaeir@ performative space. The above news article with its imagery and language imposed the same propaganda on the reader. Here, in the January $23^{\text {rd }}$ article, Chagas, the alleged criminal is identified as a "Jimmy Cliff”; automatically identifies him as a reggaeir@. His photograph describes him as a young black male who is shirtless with a tight necklace around his neck and who wears a short frazzled mini-afro hairstyle. Any reader of the newspaper who was not familiar with the reggae scene would not have been able to distinguish Chagas from all the other Jimmy Cliffs in the periferias around the Island because the description appears to fit them all. As a matter of fact, Chagas' photograph in this news article would have been indistinguishable from the album covers of the real life artist Jimmy Cliff as the descriptions fit the quintessential "rudebwoy".

Thus Chagas' face and that of all other "Jimmy Cliffs"” were made to be synonymous with what the image of a violent bandit or vagabond is supposed to look like. Additionally, many other newspaper articles from the 1970s through 2015 employed headlines that sought to instill fear in the reader with regard to the reggaeir@ space. So for instance, I have mapped out the following headlines from newspaper articles broadcasting incidences in reggaeir@ dance spaces that span over several decades; and all of them shared the common theme of demonizing the reggaeir@ body and/or space by playing on the reader's fears of exaggerated plots of violence and crime, just as the article above does with Chagas' crime announcement:

"Police found dead in a deadly shootout encounter with a lowlife "regueiro maconheiro"” ("reggaeir@ "pothead”") (Jornal Pequeno, March 18 ${ }^{\text {th }}$ 1983). 
"The usual chaos and madness in a reggaeir@ party leaves young student dead" (O imparcial, August 15 1990).

"The maddening lifestyle of reggaeir@s strike again, killing 5 young women in one night" (Jornal O Quarto Poder, March $10^{\text {th }}$ 1995).

"Owner of radiola massacred at a reggae party after its sickening after-party tragic disorganization" (Jornal Cazumba, September $5^{\text {th }}$ 2001).

"Parents beware of the wild life of reggae's maconheiros and their black power lifestyle" (A voz dos Municípios, January 1" 2006). "The fight against the longstanding problem of violent crimes in reggae parties in the periferias of Fatima and the surroundings" (Jornal Itaqui-Bacanga, October 4" 2011).

"The filth and trash produced by reggae parties seeks to change the civilization of our city" (Jornal Pequeno, July $4^{\text {th }} 1985$ ).

Similar to the first headline announcing Chagas' arrest, these examples were consistently repeated on the crime announcement pages of São Luis' newspapers in order to drum up the idea that reggaeir@ismo and "rudebwoyism" were one and the same. From 1970s until the early 1990s, news about reggae scene in São Luis only appeared on the crimes page in various newspapers and stories were often recycled. In the headline and description of Jornal Pequeno's January $23^{\text {rd }} 1981$, the details would have any reader assume Chagas was still at large. However, if readers had read an earlier issue of the same newspaper they would have been even more confounded as to what was the true identity of "Jimmy Cliff".

On October 4th 1980, the newspaper identified another "Jimmy Cliff" with the headline, "Dangerous Rudebwoy apprehended". This Jimmy Cliff was Antonio Jose da Silva from a different periferia. On January $4^{\text {th }} 1981$, two weeks prior to Antonio's crime headline, the newspaper issued another headline describing a "Jimmy Cliff" who fought 
two fishermen at knife-point. This time the "Jimmy Cliff" was policeman Jose Murilo Costa Ferreira who worked at Maranhão's Public Safety department. What all these Jimmy Cliff's shared in common was their identities as reggaeir@s and their eerie resemblance in clothing and jewelry choice as well as hairstyles that caricatured the photograph of the actual artist on his 1977 album, titled "Jimmy Cliff".

To return to the original story in the above vignette, Francisco das Chagas Costa Rodrigues was known locally as "Jimmy Cliff" in his periferia, Jordoa, but not for the same reasons that the propagandist newspapers identified him as one. According to my interviewee, R.J., Chagas embodied the reggaeir@ "Jimmy Cliffism” because he was known for his exceptional agarradinho dancing skills and popularity with local women on the dance floor of club Pop Som. So would one assume that it was just by an uncanny coincidence that Chagas suffered the same tragic fate that Ivanhoe from the Jamaican film, The Harder They Come? Following the newspaper article in January 1982, the police had been searching for Chagas for months to no avail. His charges evolved from being a mere vagabond nuisance in his neighborhood according to the elite's portrayal in the newspapers to a full-fledged gang leader by May of 1982. R.J., my interviewee recounts that Chagas had managed to skillfully remain under the police radar for months to the point that he often showed up at Pom Som for dance competitions to the chagrin of the elite.

However, on May $29^{\text {th }} 1982$, through the help of a neighborhood informant, the police tracked Chagas down and shot him in broad daylight in his neighborhood. The police claimed that they shot Chagas because Chagas and his clan of neighborhood "hoodlums" had taken over their neighborhoods with their drug sales and petty thefts. 
And yet, the periferia fondly remember him as the "Jimmy Cliff", the reggaeir@ whose passion for dance and style was unmatched (Jornal Pequeno May 16" , 1982: "Policia Prende Perigosos Assaltantes"; Jornal Pequeno June 1" ${ }^{\text {st }}$, 1982: “Crime do Coroado; Ladrao Jimmy Cliff foi Baleado pela Policia).

My goal in this chapter is tell the story of how reggaeir@ culture, particularly the reggaeir@ space has been intentionally defined by crime and violence by the elite, who then justify police violence as a form of control. At the inception of reggaeir@ music and dance practices in the early 70 s and 80 s, São Luis was a society that faced deplorable economic disparities especially in its urban areas. Poor black families from rural areas, locally known as the "interior" had moved into the urban slums and poor housing infrastructure that had been built on stilts in the mangrove-infested coastal lines of the city (see chapter 2). Reggaeir@ dancehalls and musical spaces had become the quotidian refuge for the poor black working class population who were often shunned out of white entertainment spaces in the city center. For the local elite, their worst nightmare was unfolding right in front them; their dear old city, their "atenas brasileira", their cherished "Athens" of the northeast had devolved into "Jamaica Brasileira"; an unrecognizable haven of a new black leisure served on a platter of what they perceived as black violence and sociability of alcohol and drugs. The evolution and popularity of radiola parties and events in these spaces made the elite incredibly uneasy that they employed the city's police force to brutalize the population associated with them. In the next section of this chapter, I document a series of historiographies that show how the elite through the development police documentary practices control the reggaeir@ space. 


\section{Policing the Periferias: A balance between in Laws and Policies versus land Rights and Land Control}

With the institution of Lei das Terras no. 2979, a land reform law under the governance of Jose Sarney in June 1969, the state of Maranhão sold huge portions of its priced lands to the elite. This state-sanctioned distribution of wealth follows the state's joint effort with the then military government's agenda to economically expand the northeastern region of the country the program SUDENE--Superintendence for the Development of the Nordeste. As I describe in the second chapter of this dissertation, through SUDENE major transportation infrastructure such as railways, bridges, ports and highways were built in São Luis. This groundwork contributed to the economic boom of the city because it facilitated the mining and agricultural business in the region when transportation between São Luis and other major economic hubs became extremely easier. However, with the sale of land to the small white elite through Lei das Terras no. 2979 , the state wealth and public reform came under the control of a small portion of the population --rich white families.

These families with the help of the central military government instituted laws and regulations to control the governance of the city without much resistance from it larger poor black population. Through these developments, many of the poor rural farmers, port workers and fishermen forcibly lost their land to the elite. According to archival documents from the Associacão Brasileira de Direito (Brazilian Bar Association), by early 1995 , the number of poor land owners decreased by $45 \%$, with the percentage of small land owners going from $5 \%$ in the 70 s to $3 \%$ in the late 90 s ("A 
Reforma Agraria no Nordeste: O Caso do Maranhão, Luis Antonio Camara Pedrosa, http://www.abda.com.br/texto/LuisACPedrosa.pdf retrieved on May 22nd 2015). The most fertile and useful land on the island ended up in the hands of the small white elite while the mangrove-infested brackish water areas were left for the black urban poor (ibid).

By the mid 1970s, the periferias had grown too large for the small land space that had been allotted to black working class population under Sarney's regulations. Consequently, periferias such as Liberdade, where reggaeir@ culture is deemed to have started only had places right at the edge of the city's lagoons for housing. The lack of space led the population in the periferias to build palafitas, which are wooden structures on stilts used as housing along the bay (see photo 26 below). So, during the early part of the $20^{\text {th }}$ century palafitas dwellers coped with alternating brackish waters and sinking mud under their homes during high tides and low tides respectfully. These stilt squatter settlements, in comparison to the booming portion of the island lacked basic amenities such as public transportation, running water, electricity and sewage (see Jose R Trovão, "Transfomacões Socias e Economicas no Espaco Rural da ilha do Maranhão", doctoral diss., Universidade Estadual Paulista—Rio Claro, 1994; Prefeitura Municipal de São Luis, Legislação Urbanistical Basica de São Luis (São Lis: Secretaria Municipal de Terras, Habitacões e Urbanizacão (SEMTHURB), 1997; Raimunda Barbosa Costa, "Practica Social da Uniões de Moradores de São Luis do Maranhão, master’s thesis, Pontifica Universidade de São Paulo, 1984; Wilson de Barros Bello, "Historia do Planejemento Economico no Maranhão; Uma Arqueologia dos Planos Estaduais de Desenvolivemento (Rio de Janeiro; Papel Virtual, 2004). 


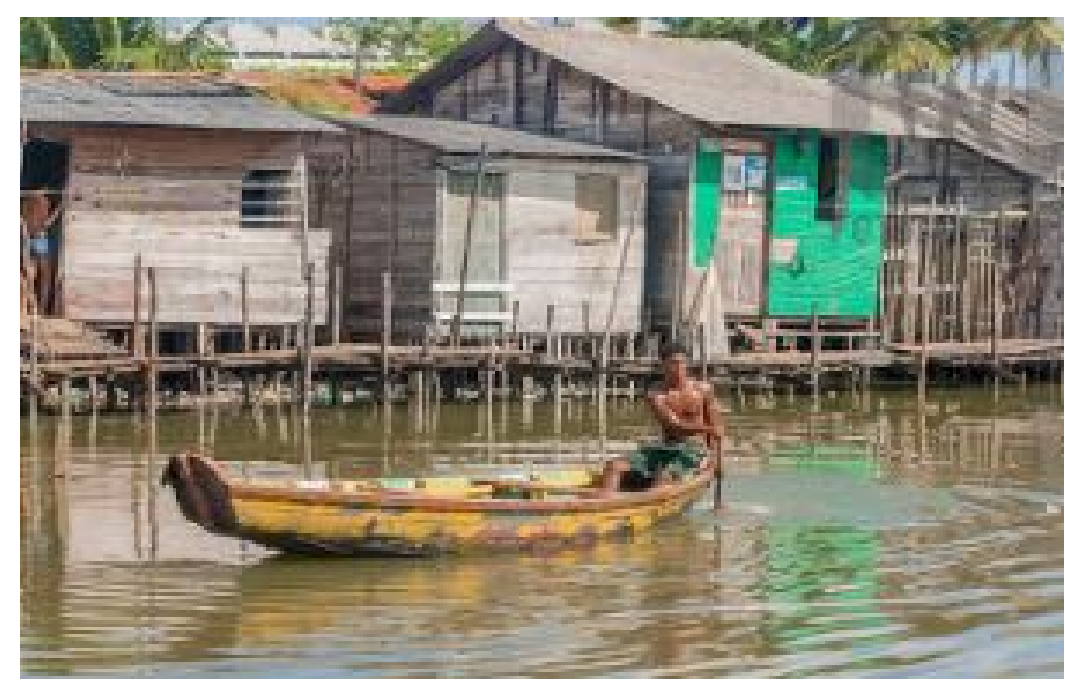

Photo 26: Picture of a typical Palafitas in São Francisco periferia

For the most part, the population living in the periferias on palafitas were segregated from the richer areas in the city center and the Southwest areas that were sold to the white elite. Nevertheless, as more poor migrants moved into the poor areas, they sought employment in the homes of the rich as empregadas (domestic women workers), gardeners and the like. Many more poured onto the streets of São Luis as self-employed vendors, artisans and produce retailers in the city center. With the intent to keep their the poor black population out of their neighborhoods and streets, the elite began the propagandist project to claim their land ownership rights by interpreting the Sarney laws and regulations of land rights through the documentary practices of heavy policing of the rich neighborhoods (Interviewee, J.B., interview with author, July $24^{\text {th }} 2016$ in Centro Historico).

The physical policing of poor black population from the periferias using land right laws served to keep poor black people out of the rich neighborhoods and the streets 
of the city, unless they were there to work or serve the elite. Moreover, as described above, the demonization of the poor black neighborhoods and its reggaeir@ population using propagandist media outlets such as newspaper also served to instill fear in the general population. Yet, according to several interviewees, the elite had the most success in these exclusionary documentary practices by controlling who had access to their spaces of entertainment and leisure.

In the 1970s, São Luis' main elite social clubs consisted of the Jaguarema Recreation Clubs in the neighborhood of Anil, Casino Maranhese in centro, Gremio Litero Portugues, the Sergeants Club in Joao Paulo for members of the military and RBV in the neighborhood of Fatima. These clubs only gave access to elite families and the wealthy. My interviewee A.N. recalls that working at the Gremio Litero club as a cook but could never visit it dance spaces because it granted access to only white Portuguese immigrants and white Brazilian who are descendants of the Portuguese. Places like the Casino Maranhese enforced these exclusionary practices by ensuring that all members had membership cards. According to the newspaper $O$ imparcial's New Year's Eve "Friendship Ball" announcement in December 1966, the club security was to ensure that new members did not carry forged documents by posting the following statement on its front page:

The club will not allow non-family members of the elite into the establishment unless they have direct invitation from the club's Secretariat or they were directly invited by the state government. All attendees are to present their membership cards and evidence of their club's monthly dues at the door. Members who intended to bring out of town family affiliations are required to have sought permission from the club's board of directors to get written proofs or approvals to show at the door. 
During the Carnival and festas junina seasons (see Chapter 2), the elite continued to perpetuate these segregationist practices by creating their own balls that were separate from the general public. According to Araujo (2001), the elite exclude the city's poor from their entertainment spaces by stigmatizing that population as "drunks, vagabonds, pimps, troublemaker, and criminals"; essentially the worst of society who did not deserve to share the same spaces of leisure as them. Additionally, the elite engaged in newspaper smear campaign against radiolas or sound system companies that played in reggaeir@ spaces in the periferias. For instance, in October 1968, the newspaper Jornal Pequeno published the letter of an irritated elite woman complaining about noise violations against radiola Carne Seca (see Chapter 2). The letter also accused the sound system company of hiring "vagabonds" who steal construction products from their bosses in the wealthy neighborhoods to build their sound systems. In retaliation, the owner of Carne Seca, responded to the elite woman's letter in another newspaper article. In his response, the radiola owner overemphasized his reputation as "a well-educated electronic engineer from a "respectable" family of great wealth" in lieu of a businessman or sound system owner who rented his equipment to reggaeir@s in the periferias. Carne Seca's defensive letter interestingly spoke directly to the elite's perception of the sound system business, especially one that catered to reggaeir@s as a non-respectable profession.

According to archival documents from the Department of Political and Social Order (DOPS), sound system companies were often targeted by the policia militar during the Republic's military dictatorship in the early 1970s, especially when the sound systems were affiliated with the black social movement's cultural events (See Alberto (1983), "When Rio was Black" and Almeida and Lamen (1988) "Projeto Sonora 
Paraense). The military government through DOPS had its intelligence committee investigate many sound system owners as a way of intimidating them from associating with the "black soul" and "black power" movements that had caught on in the black music scenes in Rio de Janeiro and São Paulo. On the island in São Luis, although DOPS did not participate in the smear campaign of sound systems in the roots reggae scene, the elite pushed for the policia militar to raid radiola events and dance spaces in the periferias using state and municipal land rights laws. Accordingly, in the early 1990s, as the smear campaigns of the sound system business increased, many of the elite population in São Luis who had found the business profitable were forced to leave it for working class population in the periferias.

\section{Policing of Particular Reggaeir@ Dance Spaces in the Media: The case of Club Espaço Aberto}

In the performance ethnography chapter of this dissertation, I document my visit to the Club Espaço Aberto and its role in the reggaeir@ performanscape. Here, I discuss the historiography of this performance space as it pertains to the elite's active practice of policing reggaeir@s in this space. In the late 1980s, at the heights of the opening of many dance spaces in the periferias, Club Espaço Aberto was opened to the working class neighborhood of Ilhinha. This club is fascinatingly located between the elite neighborhood of São Francisco and the periferia Ilhinha. The space, which is an open area used to be called Cajueiro because of the large cashew tree that stood in the middle of venue. The space was used in the past for various sound system events such as forró festivities. In the 1980s, Luis Fernando Santos Costa Ferreira, known locally as Ferreirinha, the owner of an amateur football club, Estrela Futebol Clube, bought the Cajueira space and turned it into a club. With the introduction of "international music' 
(see chapter 2), Ferreirinha decided to play roots reggae on the sound systems instead of forró as it had previously been doing in past events. He entered into a contract with the sound system Estrela do Som, then known as Arco-Iris do Som to play in the space when he renamed the space from Cajueira to Espaço Aberto.

Ferreirinha's strategic marketing skills, the space's widespread annual celebrations such as Festa da Recordacão and Festa da Paz and the popularity of the sound system Estrela do Som drew in large crowds. In 1987, Espaço Aberto surpassed Quilombo in the neighborhood of Fatima as the most renowned reggaeir@ club in São Luis. Similar to the smear campaigns of popular sound systems, popular clubs like Espaço Aberto began having conflicts with the elite, especially because the space was located near the wealthier residential and commercial areas of São Francisco. Espaço Aberto drew in the crowd from the stilt communities of São Francisco making Travessa Epitacio Cafeteira, the roads connecting Espaço Aberto and the wealthier neighborhoods a popular hangout spot for young black males and rival gangs from various slums around the city.

According my interviewee, R.M., this prompted the elite residents of São Francisco to make several complaints and reports to the $9^{\text {th }}$ district police station. Other elites in these neighborhoods especially those with power connections to the police force and the media began to rally against Espaço Aberto concerning its events. In an unfortunate event on October $3^{\text {rd }} 1987$, a young man by the name Nilson Nogueira who had left a night event at Espaço Aberto boarded an after-hours bus no. 618 to periferias of Maiobão. While he was on the bus, another favelado (resident of a favela) named Paulo Bomba got into a fistfight with Nogueira, stabbing him to death on the bus. Although the 
intricacies of the incident were quite unclear according to various interviewees, it created an opportune time for the local elite to start yet another smear campaign against Espaço Aberto.

Once again publishing on the crimes pages of local newspapers, the elite led with sensationalist headlines, which read as follows:

"A riot in Espaço Aberto leads to a violent end" (O imparcial, October $4^{\text {th }}$ 1987)

"Youth murdered after Party AT Espaço Aberto” (O Estado do Maranhão, October $4^{\text {th }}$, 1987)

"After a Reggae party, reggaeir@ was murdered inside a bus” (O imparcial, October $4^{\text {th }} 1987$ )

As with the story of Chagas in the vignette above, the newspapers propagated the intended agenda of the elite to get rid of Espaço Aberto. The newspaper $O$ Estado do Maranhão asserted Nogueira was with his friends (although he was in fact alone) and these friends instigated the fight for Nogueira to hit Bomba. Bomba, a popular reggaeir@ who was already in the newspapers for other crimes, retaliated with by physically charging Nogueira with insults while he stabbed him several times to death. Two reggaeir@s I interviewed who happen to be at the club that night recounted that the incident in fact had nothing to do with Espaço Aberto; the event did not occur at the club nor did have anything to do with the event at the club as the newspapers have reported. The newspaper, $O$ imparcial presented this news on its crimes page in a rather exaggerated version that fed into the elite's end to demonize reggaeir@ culture by taking Espaço Aberto down through the media. The article read as follows: 
The crime was a result of a violent riot that occurred in the wee hours of the club, Espaço Aberto, which has recently been denounced by the traumatized residents of travessa Epitacio Cafeteira as the epicenter of marginais/hoodlum, macoheiros/"pot-heads" and arruaceiros/indigents. The incident on Friday night was just another normal evening at this establishment for those who enjoy playing with their lives. In a war of words, the victim and his group of friends got into a conflict because of an argument over two underage girls. Later, at the end of the night Bomba's gang chased after Nilson's gang who were on their way to catch the latenight bus to Maiobão. When the bus stopped, Nilson, Josiel, Joerbete and Henrique, the first group of boys from the club boarded it. Nilson, who was already on the bus in the back was violently attacked by Paulo with a knife, ramming the weapon into Nilson's chest. Nilson's lifeless body was found in a pool of blood. The authorities of the Security Secretariat was informed about the murder and yet they have not been able to trace the location of the criminal and his friends. However, the city's police superintendent Leofredo Ramos has strongly suggested that Espaço Aberto should be shut down and its gates be closed off by the police at the behest of the residents of Epitacio Cafeteira street.

With reports like the one above the newspaper, $O$ imparcial depicted the nightclub to be an insufferably violent dance space that illegally permitted entertained underage minors, inevitably rendering the dance space as one of crime and violence. Even though several witnesses who were present that night had refuted the assertions of the newspaper concerning this case, the witnesses' efforts proved to be futile (Linaldo Jefferson Pereira Martins, "Espaço Aberto,” O Que Diz o Leitor, O Estado do Maranhão, October 11, 1987). The newspaper strongly suggested that the barricading of the entrance of Espaço Aberto and eventual shut down the club was the only way to resolve São Francisco's elite neighborhood'd issues with crime. The responses of readers from the elite neighborhoods was telling of the rhetoric of crime and violence it had created in the minds of many residents. Some of these elite residents concurred with the newspaper for the police force to increase its policia militar surveillance of the nightclub. They insisted the city provide the neighborhood more protection by putting more patrol cars in the 
neighborhood and around the club. As one resident put it, "the rigorous policing of spaces like Espaço Aberto will ensure that the marginais/the vagabonds stay out of our neighborhoods to create a better sense of security for our community. (Januario de Sousa Ferreira, "Lei do Silencio," O Que Diz o Leitor, O Estado do Maranhão, October 6, 1987).

Following this major incident, the newspaper published yet another incident that further demonized Espaço Aberto and the reggaeir@ community. This new incident also included references to the murder on the bus to further embellish the article. The headline which read "Reggae e Estupro/Reggae and Rape" was followed with the following narrative:

After leaving the reggae club Espaço Aberto the 15 year old helpless girl was stalked by four so-called reggaeiros. These young rascals with itinerant hairstyles [referring to their dreadlocks] followed the young girl while she walked across Epitacio Cafeteira street. These maconheiros/potheads who had been smoking all night dragged her across the street into the bushes, tore off her clothes as she screamed vehemently with all of her strength for help. Fortunately, some residents of the respectable neighborhood nearby came to her rescue by rushing out of their homes, driving the insolent vagabonds to run back to the club. (Reggae e Estupro,” O Imparcial October 18, 1987).

Because $O$ Estado with its various articles had branded Espaço Aberto as an inferninho - a hell-hole. It influenced other newspapers to label all other reggaeir@ spaces as hell-holes that needed to be shut down. The city then decided to indict the nightclub in order to shut it down. To the city’s surprise, the reggaeir@ community mobilized themselves against the media's admonishing of their spaces, especially Espaço Aberto. In response to $O$ Estado do Maranhão's two major articles that prompted the city to violently police and shut down some of their spaces, various reggaeir@ communities 
organized protests asserting racial and class discrimination from the city government and the elite. A popular responsive letter to the city that initiated the protests was written by Linaldo Jefferson Pereira Martins, a reggaeiro from Monte Castelo neighborhood. In this letter, he states that if the elite and the police seek to close down reggaeir@ nightclubs because they perceive them as

"maconheiros (potheads), thieves and prostitutes, then they would also have close every other nightclub in the country, including the elite's social clubs that are also characterized by their cocaine usage, silver-spoon-fed brats, white-collared crime gentlemen alongside their well-dressed loose women”. (Linaldo Jefferson Pereira Martins, Espaço Aberto, "O Que Diz o Leitor, O Estado do Maranhão, October 11, 1987).

Essentially, the pushback from the reggaeir@ community did a great deal to minimize the media's attack but unfortunately it did very little to eradicate the discourse of violence and crime that the elite had successfully created about their performative spaces. The trajectory of police violence practices in the reggaeir@ space that stem from this discourse is indeed a complicated one. In this section of this dissertation, I briefly discuss some of the histories that resulted from the local elites discursive criminalization of the reggaeir@space and the reggaeir@body.

\section{Tracing the Violence: Politics and Policing of the Reggaeir@Space}

Throughout the 1970s until the latter part of the 1980s, the then administrative governor of São Luis, Epitacio Cafeteira came into power by campaigning to end urban violence and the conflict over land rights in Maranhão. Following Cafeteira's election, Davi Alves Silva was also elected mayor of the state's capital Imperatriz in 1988. Silva, an ally of landowners and a reputed head of the pistoleiros/local hitmen who violently persecuted peasants over land rights, he had to be appeased by Cafeteira with the promise 
to allow him to independently govern Imperatriz. This was to be in return for not inciting violence against the policia militar (Melo, Historia do Maranhão). Concurrently with these campaigns, the Deputy Mayor of São Luis, Jairzinho da Silva, together with Luis Gonzanga Ferreira, a former renowned reggaeir@ DJ at the nightclub Pop Som were organizing urban land rights and anti-police-violence protests for reggaeir@ spaces. Newspaper archival documents show that the attack of the media that was launched against reggaeir@spaces came about as a result of prior media exaggerations of the general climate of violence and the provocative community organizational protests of the Deputy Mayor and his former DJ counterpart ("Luizao Incendeia Casebres Comunitarios," O Imparcial, November 25, 1989; “Comerciaria Agredida a Socos por “Luizao,” O Imparcial, November 28, 1989).

Several interviewees recounted that the media made it seem as if the violence in the city was becoming uncontrollable and Mayor Cafeteira's administration was incapable of getting it under control. This resulted in protests by various elite neighborhoods in an effort to prompt Cafeteira to shut down the reggae clubs. The media also attacked the policia militar, accusing them of being useless and inefficient at monitoring the excessive crime. The then Secretary of Security responded to these accusations by increasing police surveillance and putting a sweeping number of patrol cars on the city's streets than it had ever done before. Moreover, the main attention for this increased police efforts was centered on the reggaeir@ clubs, thanks to the elite's manipulative attacks using the media. My interviewee, JW, recounts that with the increase of police presence in reggaeir@ spaces came excessive use of force and brutality in reggaeir@spaces because it had been legally sanctioned by the local government, as 
directed by the elite. By the end of the 1980s, excessive police violence in reggaeir@ dance spaces had become so commonplace that it was nothing new to read or hear about the policia militar consistently killing reggaeir@s without any repercussions ("Carta Aberta ao Governador Epitacio Cafeteira" Jornal Pequeno, October 1, 1989; "Seguranca Maior para o Coroadinho," Jornal Pequeno, December 7, 1989; "Policia Civil de Bracos Cruzados," Jornal Pequeno, December 12, 1989).

On November $25^{\text {th }}, 1989$, the policia militar committed the most atrocious mass brutality against reggaeir@s til date. On this occasion, under the leadership of Lieutenant-Colonel Cantanhed, about 100 policia militar were dispatched to operate a major sting at the club Espaço Aberto. The brigade arrived in several vehicles that included armed men in trucks and large vans. These police stormed the club unannounced that night where they were booed and verbally protested when they decided to arrest a very popular DJ and radio personality Ademar Danilo and Roberto Casau, the Secretary for the Society for the Defense of Human Rights in Maranhão, who were all in the club that night for a major reggae event. My interviewee, DJ B. stated that Danilo and Casau were arrested only to be later released because the police were aware that those two men were politically connected and they did not want to harm them in the succeeding sting that ensued that night. The policia militar returned to commit what has been described in many newspaper archives as the largest police massacre of that decade (Cadever de Rapaz Encontrado na Matas do Aracagy com Marcas de Bala” Jornal Pequeno, October 16, 1989; “Justiceiros Voltam a Matar: Jovem Executado a Tiro de Escopeta,” Jornal Pequeno, October 19, 1989; “Tiroteio e Morte no Clube Som Brasil,” Jornal Pequeno, October 27, 1989). 
In this vicious event, the policia militar in the absence of the DJ and the Human Rights journalist, brutally attacked over 500 reggaeir@s by haphazardly beating, kicking, spraying tear gas and hosing down the crowd in Espaço Aberto without any provocation (Operacao Desarmamento do PM gera Tumulto no Espaço Aberto, O Estado do Maranhão, November 26, 1989; Violençia no Espaço Aberto, O Estado do Maranhão, November 28, 1989) . Many reggaeir@s were arrested and many others had to be rushed to the hospital for sustaining grave injuries where numerous people became statistical casualties (Esquadrão Executa mais Um nas Matas do Aracagy,” Jornal Pequeno, November 11, 1989; “Com Tiro na Nuca; Empresaria encontrada Morta no Loteamento Lago de Cisne," Jornal Pequeno, November 2, 1989). Although many newspapers condemned the police actions in this historic "reggaeir@ massacre", a vast majority of them focused on the how young reggaeir@s retaliated by fighting back, killing a few police officers ("Filhos de Empresarios Matam Policial e Ferem Commisario a Bala," Jornal Pequeno, November 3, 1989). In the end, the resulting ramifications of this brutality of the reggaeir@ community formed the foundations for the interactions between reggaeir@s and the policia militar.

In the last section of this chapter, I engage in the analytical discussion of the process of the discursive "otherization" of musical practices such as reggaeirismo through violent policing and how that process relates to the reggaeir@ [black] body.

\section{Transformation and Appropriation: National Mainstreaming Working Class Musical Forms}

The late nineteenth and early parts of the twentieth centuries in Latin America and the Caribbean region saw the migration of vast populations of poor from the rural areas to 
the urban zones. This influx of the lower class into urban cities widened the class gaps between the poor and the elite in these areas. These developments were also accompanied by widespread capitalism, national industrialization and expansion in national economies that linked many markets to global circuits of exchange (Malm 1992; Bethell 1998; Bulmer-Thomas 2003). The poor class of many of these nations brought with them into the cities, various musical forms and styles from the rural areas. Béhague (1996) states that during this period pervasive cultural nationalism that manifested as musical nationalism involved the appropriation of "traditional" element in the music community. Most significantly, in many Latin American cities, the state's appropriation projects involved the "cleaning up" of musical forms developed by the working class neighborhood, which are then transformed into "proper" styles that fit into the national symbols (Pancini Hernández 1995; Austerlitz 1995; Díaz Aya 1981: Savigliano 1995; Monsiváis 1997; Washabaugh 1998b).

As seen with Brazilian samba and maxixe, Argentianean tango, Puerto Rican danza, Mexican ranchera, and Cuban rumba and son, national popular musical forms created by working class urbanites through the syncretism of European, African and sometimes indigenous-derived forms were modernized and promoted as acceptable national dances, when they were not viewed as such at their inception. These national projects ensured that "lower class syncretic forms gradually percolate[d] upwards, acquiring more musical sophistication and eventually coming to be enjoyed by the upper classes" (Manuel 1995, 15). 
Wade (2000) responds to Manuel's (1995) upward "percolation" of music to the upper classes by contending that although this is the general trajectory in the Latin American and Caribbean region,

"It is important not to oversimply the processes involved. It is necessary, first to appreciate the syncretic nature of the lower-class forms, which feed off a host of different musical current. This helps us to avoid falling into an oppositional model in which the musical styles in question is formed entirely by subaltern classes, located "in the barrios" and then taken and modernized. There is no simple opposition between the local and the national (or between these and the global), or between the traditional and the modern. Instead, the music "in the barrio" was actually created in complex processes of interchange, class, mediation and appropriation that worked in ambiguous spaces between country and city, between social classes, and, not infrequently between the national and the international" (8).

Wade's (2000) perception here concerning the simplistic oppositional view between the local and the national ties in well with Puri's contentions of localizing hybridity, by locating hybrid musical forms with specific and local cultural and political context (see chapter 1 and 4). As such, the interactions and interconnections of how popular music styles cross boundaries between the rural and the urban, between the classes and between nations and the transnational become essential in defining the interpellations of musical performative in relation to statist discourse. Additionally, how elements of music hybridity are defined as "modern" versus "traditional" or "national" versus "local" have to be labeled categorically and comparatively against other forms that may not be necessarily classified as such. Therefore, Wade (2000) points out that

"If everything is appropriated and made national, then the danger of erasing hierarchies of class and cultures rears its head. Like any meanings, national meanings are defined relationally, both with respect to other nations and to forms within the nation that are defined as inferior. So appropriation implies a parallel process of differentiation" (8). 
In light of the intricate elements that impact how local musical forms become modernized and nationalized, the notion of appropriation needs to be analyzed complexly rather than in simplistic oppositional notions as I have illustrated above. Brackette Williams (1991) intervention on the processes of transformation and appropriation in Guyana shows the complex relationship between heterogeneity and homogeneity through assimilation. Here, she borrows the Gramscian notion of "transformism" to conceptualize what she terms as "transformist hegemony" 29 ; which occurs when the processes of homogeneity as practiced by the state impacts heterogeneity "by assimilating elements of that heterogeneity through appropriations that devalue them or that deny the source of their contribution" (30). Her conception of "transformist hegemony" is also similar to Raymond William's (1980) "selective tradition", which states that tradition is "always passed off by the [ruling class] as "the tradition," or the "the significant past,"'” who then choose from a whole multiplicity of connotations and practices by highlighting some meanings rather than others and by extension even misconstruing meanings and diluting them (39).

Accordingly, Brackette Williams' intervention asserts that the assimilating elements of heterogeneity through appropriation by the state, do not afford the marginalized or otherized group the space to lay claim to ownership of aspects of cultural elements within the national context. Where this occurs, those elements are deemed to have no value and those laying claim to its ownership are then ostracized as "not "true members of the ideologically defined nation" (Williams 1991, 31). Contrastingly, if the

${ }^{29}$ Gramsci's (1971) "transformism" refers to the notion that the formation of an "ever more extensive ruling class in 1848 Italy "involved the gradual but continuous absorption...of the active elements produced by allied groups - and even of those which came from antagonistic groups and seemed irreconcilably hostile" (58-59). 
marginalized group tries to appropriate the cultural elements of other groups in the nation that are deemed to be of higher value as defined by the nation, they "stand accused of riding to the pinnacle of civilization on the coattails" of others that are actually afforded the title of "the real producers" (ibid.). Consequently, groups defined as real producers of core national culture attain the discursive power to reconstruct the meanings of the cultural elements appropriated from the otherized groups. In this instance, heterogeneity is not obliterated as the oppositional view, however it materializes under different conditions as the same cultural element attributed with different interpretations by various groups of people in the national context (Williams 1991, 30-31). As Bhabha (1994) emphasizes, this ambivalent enunciatory feature of national discourse concerning the performative is not accidental; it is indispensable in order to maintain racial and cultural hierarchy.

Here, in engaging Williams' (1991) intervention concerning value and appropriation, in the case of reggaeir@ performance-scape, Afro-Maranheses are borrowing from the enunciative forms of other Afrodiasporic spaces in the Caribbean and not from otherized groups within Brazil. Additionally, I suggest that in the reggaeir@ performative space, unlike other black cultural spaces in Brazil that "Africanize" the cultural enunciations in order to lay claim to its ownership, the borrowed cultural elements from other Afrodiasporic spaces in reggaeir@ spaces are “Caribbeanized.”(See this discussion in detail in Chapter 4). The "Caribbeanizing" of the enunciative elements of the reggaeir@ performance-scape affords reggaeir@s the agentive claim to being "real producers" of the creations and moments in the reggaeir@ performance space. This in turn, gives reggaeir@s the counter-discursive power to define reggaeir@ black identity 
that challenges statist discourse differently. My argument here is that because often times in Afro-Brasilidade Space the dialogic response to statist discursive portrayal of blackness have been agentive "Africanizing" of embodied performative blackness, the enunciations of the reggaeir@ space response and challenge statist discursive ideologies of blackness differently. Consequently, the ideological and epistemological contestation of statist discursive blackness compel the state to want to control the reggaeir@ performative space through the violent documentary practices of policing. In the next section of this chapter, I examine the power, discourse and action dynamics between statist documentary practices of violent policing against reggaeir@ bodies.

\section{Racial Contact: Reggaeir@ bodies Under Affirmative Action Policies}

In the ethnographic chapter of this work, I explore in detail my documentation of police violence in the reggaeir@ performative space. In the fourth chapter of this work, I also examine why the reggaeir@ space is viewed as counter-discursive and counter hegemonic. In the previous section of this chapter, I briefly discuss how reggaeir@s agentively lay claim to ownership of their cultural enunciations by engaging Williams’ (1991) conception of cultural producers as it pertains to statist portrayal of "the other's" culture. In this portion of the dissertation, I explore the dynamics of statist control of reggaeir@bodies in the reggaeir@performative space.

I contend that "violence against the black body [in Brazil] is a rehearsed, embodied, haunted script" that predates affirmative action policies (Smith 2016, 378). I make this assertion based on my aforementioned arguments that the formation of the Brazilian nation-state is characterized by the production of discursive ideologies about black performatives spaces that is challenged by the reggaeir@ performance-scape. The 
documentary practices of the Republic at its inception through the state's military regime has always been characterized by militarized policing (Pedrosa 2012). A form of the policing that the present nation-state inherited and continues to employ. One may even argue that violent policing of black bodies dates back to Portuguese enslavement of black bodies where "scenarios of racial contact are [produced] in the moments of violent encounter when [reggaeir@] bodies meet in performance zones defined by discourse, power and action" (Smith 2008, 26).

These scripts of violent control of black bodies through the history of Brazil's statist formation continues through the institution of affirmative action policies, especially because affirmative action fails to address the realities of racism and persistent racial hierarchization inherent in Brazil's hybridized discourse of racial democracy. Consequently, affirmative action policies through the pervasive code of silence over racism become instrumentalities of violent encounters between the police and reggaeir@ bodies in "scenarios of racial contact". This is because the documentary practices seek to instill control over black bodies that lay claim to cultural elements that are deemed not to belong in the national imaginary or peoplehood (Smith 2016, 378; Sheriff 2001; Vargas 2004).

Although through the institution of affirmative action policies, Brazil appears to be addressing racial disparities, the codes of silence surrounding the realities of documentary of violent policing negates its efforts of equality in practice. The dangers of this silence is that "the arms of the state - the police and the military — deploy total violence as a regulating tactic" that aim to silence and invisibilize reggaeir@ bodies because their performative spaces challenge statist hegemony (Silva 2009, 212). 
In response to the code of silence instituted by affirmative action policies, reggaeir@ bodies dialogically respond repeatedly with "performance... [which] involves enactment, re-creation, or storytelling... [that are] metaphoric, or symbolic of life" (DeFrantz and Gonzalez 2014, 6). The reggaeir@ body in endurance of statist documentary practice of violent policing, dialogically responds particularly with black performance, "which expands, synthesizes, comments, and responds to imaginations about black identity...if black identity is constructed and articulated by those outside of the "race" then performances of blackness are created in response to those imagined identities as well as to cultural retentions and African histories" (ibid., my emphasis). In succeeding chapters of this work, I explore in detail how these black performance are translated through productions in the reggaeir@ performance-scapes. 


\section{Chapter 4, Reggaeir@ Culture as Counter Discourse}

The central concern of this chapter is focused on the ways in which roots reggaeir@performatives spaces are viewed as counter-discursive that challenge the statist discourse of racial democracy, affirmative action and hybridity. My main argument here is that the performative spaces of roots reggae music and reggaeir@ practices in São Luis like most black musical in Brazil are seen as incompatible with the dominant forms of Brazilian national identity as defined by racial democracy and affirmative action policies. This is because the performatives and the spaces they occur in like other music and dance practices of nordeste, are associated with a space in the Brazilian national imaginary that is discursively considered "too black", marginal, backward and folkloric. Hence, even within the institution of affirmative action correctives (as discussed in the previous chapter), the performative of reggaeir@s still carries the attributes given to it by the discourse of racial democracy as "common" and "vulgar" black musical practices that do not fit into the dominant notion of Brazilian national peoplehood. The reggaeir@ performative spaces become the conceptual space of production for these musical practices that are viewed as incompatible with national narratives. As such they are heavily and violently targeted by the policia militar.

I argue that the entire counter-discursive performance space organized around roots reggae musical practices, engages the performative space of Afro-Maranheses as it manifested beyond the actual performance. I suggest that Afro-Maranhese identity is organized through and within the performative space of roots reggae music and dance. I also suggest this relationship is dialogic as it influences Afro-Brasilidade Space as a product of statist discourse, but it is also distinguished from Afro-Brasilidade Space as a 
diasporic space that is different from hybridity, particularly creolization. It is important to understand these relationships in order to grasp how multiple and unequal representations of national identity relate to each other through contestation, appropriation, and transformation within the intersections of race and citizenship.

Finally, I suggest that there is clashing politics of culture and representation involved here, where statist definition of citizenship and Afro-Brazilian definition of citizenship are imbued with different potential meanings of nation, race and music. It is important for the reader to note that such cultural politics are also spatialized, gendered and sexualized, although that is not the focus of this dissertation. In the Brazilian case, the perception of the nation as a territory demands that the racial and cultural distinctions are captured through a spatialized politics of social relations. That is to say that the ways in which people perceive identity, music and dance is interconnected with their notions about places. Similarly, different notions about racial and national identity connote the proper places of women and men can occupy as it relates to their sexual congress in the embodiment of music and dance practices.

These connections, map out the ideas I will be exploring to support my arguments. In the next section of this chapter, I explore the theoretical approaches to the production of Afro-Brasilidade Space; here I suggest the connections between music and dance practices, national identity, peoplehood and citizenship. 


\section{Defining Citizenship: Ethnopolitics, Ancestralidade, and the Production of Afro-}

\section{Brasilidade Space}

Affirmative action has done nothing to change nothing! This is a dangerous cycle for us [referring to Afro-Brazilians]. They create nonsense laws all the time and they pretend as if they understand us and who we are, our culture, our mindset, the way we think, our struggles, our fears, what we like, what we don't like. The politicians in this country and especially in this state [referring to the state of Maranhão] are like Princess Isabel. They come and take what we have already created. Sign documents and go back to pretending. It is all fake, understand? It is all fake, you know? (“Interviewee A.T.”, Centro Historico, São Luis January $3^{\text {rd }}$ 2016)

On May $13^{\text {th }}, 1888$, Princess Isabel of Portugal formally signed the Lei Aurean (The Golden Law) that officially abolished slavery. During this time period, the formal transactions of the Trans-Atlantic chattel slave trading had ended in most parts of the Western Hemisphere, thus, most black slaves in Brazil had already been freed by their slave masters (Da Costa 2010). Moreover, the official abolition that was signed by Princess Isabel did not do anything to impact the disparity that continued to exist between the descendants of slaves and the white elite, such that socioeconomic and political structures remain intact to ensure the perpetual maintenance of racial hierarchization in Brazilian society. Irrespective of these accounts, dominant historiography continues to uphold May $13^{\text {th }}$ as the end of racial subjugation. This fact amongst others, substantively informed the statist ideologies of racial democracy in many aspects. Statist documentary practices of presumed equality that do not match up with the lived realities of racial hierarchization in Brazilian society are what my interviewee, A.T., was referencing in the above quoted interview.

Historically, the predominant white Brazilian elite has always written official historiographies that both minimize Afro-Brazilian contributions to Brazilian society and 
also obscure the experiences of racism and racial discrimination. Afro-Brazilian desire for representation appears to stem from the centuries of the absence of the history of African descendants history and black culture from Brazil's official historiography. With the institution of affirmative action policies, Federal Law 10.639.03 required schools to include African and Afro-Brazilian history into the academic curriculum. But again, the implementation of this law like all others associated with affirmative action policies, has been difficult as white school officials of many educational institutions, plagued with the ideology of racial democracy have been in no rush to enforce changes. As such, in most arenas of society Afro-Brazilians have always engaged in agentive cultural practices that serve as dialogic responses to hybridized statist discourse that perpetuates racial hierarchization and inequality. In these efforts, Afro-Brazilians contest and challenge national discourse of belonging by proposing the storytelling of Afro-Brazilian historiographies themselves. They assert the need for what Da Costa (2010) terms as "protagonismo negro" (black protagonism) that define their own identities and contribute to the policies and politics that impact their lives (214).

Black protaganism in Brazil has been carved and articulated through the intricate performance of spiritual and cultural practices that can be translated dialogically as political assertions to state documentary practices of oppression (Moura 1994, Da Costa 2010). Due to the fact that over the centuries the Brazilian state officially continued to enact policies in the name of racial equality do not documentarily translate in practice for Afro-Brazilians, the need for Afro-Brazilians to reinforce the articulations of spiritual and cultural enunciations that define their ways of belonging has been persistent. In other words, the state and Afro-Brazilians have always spoken different languages in terms of 
defining citizenship and ways of belonging in national peoplehood. Afro-Brazilian spiritual articulations of belonging have been defined through the commitment to African-derived religions, especially Yoruba cultural-based religions. These mainly include Candomblé, Tambor de mina, Umbanda, Cantimbo, batuqué amongst others. Music and dance practices, which have often been derived from these spiritual articulations, have equally been a space of articulation of belonging. Consequently, black-identified music and dance practices, fashioned as forms of self-representation and the meanings produced within the performance-scapes such as afoxé, capoeira, tambor de crioulla, and reggaeir@ music and dance practices (as I will portray in this chapter) have consistently been targeted by state policing practices (Smith 2015).

Da Costa (2010) argues that Afro-Brazilian agentive power to express ways of belonging, politically through cultural and spiritual enunciations "originates in Candomblé philosophies and African and Afro-Brazilian epistemologies where sonic creation and bodily movement embody knowledge and history and produce the potential to transform space and possibility" (321). She takes for instance, the bahian musical practice afoxé, which literally means "an enunciation that makes something happen", to deductively suggest that afoxé musical practices that derive its song, dance and ritual practices from the Candomblé terreiros (Afro-religious worship houses or compounds) have been used by Bahians to politically assert how to belong in Brazil. Citing Santos (1976) and Leite (1992), Da Costa explains that agentive power comes from the knowledge of Yoruba culture and Candomblé rituals because in these spaces, it is believed that "axé" as "energy and knowledge pass directly from one person to another through gestures and words accompanied by corporeal movements" (ibid). Hence, for 
Afro-Brazilians, the agentive power to use music, dance, and afro-religious practices to politically challenge statist discourse of citizenship can only come from the dialogic practice of the cultural and spiritual enunciations of blackness.

As per my previous discussions of the notion "ancestralidade" (see my detailed of discussion of this in Chapter One), here I suggest that the critical knowledge of AfroBrazilian struggles, philosophies and practices passed down historically, have come to define the politics of Afro-Brasilidade Space, which serve as the main resource of agency for Afro-Brazilians in the critical challenge to contemporary struggles for equality and construction of national peoplehood. In the next portion of the chapter, I trace the genealogy of the ethnopolitics that produces and sustains Afro-Brasilidade Space.

\section{The Creation and Production of Afro-Brasilidade Space}

Various historical processes have impacted the production of Afro-Brasilidade Space, which is the conceptual term that I employ in this project to convey the dialogic performative space that represents the series of repeated responsive performances that Afro-Brazilians engage in, in contestation of statist discursive notions of black identity. These historical processes have contributed to the complex conception of points of contact and dialogic interpellation within discursive statist policies, intellectual production of race and the cultural, religious and political mobilizations of the movimento negro.

The vast number of Brazilian and Brazilianist scholarship on black identity in Brazil has identified the immense influence that Salvador da Bahia as a black cultural mecca has had and continues to have in the cultural production of Afro-Brazilian epistemologies and philosophies in other black spaces in Brazil. The question then lies in 
how Salvador became the cultural hub for the negotiation of racial hegemony in the arena of cultural politics, and its relation to Afro-Brasilidade Space? The practice of Africanderived religions especially Yoruba religions as I discussed above for the most part has defined the source of knowledge and empowerment for the challenge of black cultural politics. The sect of Candomblé practiced by Baianos in Salvador is influenced by Yoruba Nagô and Mina while the other terreiros for the most part in other parts of the country are influenced by Angolan, and Benin African traditions (Olupona 1993, Reis 2004, Carney 2003, Cornwall 2003). Consequently, considering that the agentive power of self-fashioning, and self-representation produced within the performance-scapes in Brazil are derived from the embodiment of Afro-religious practices in black spaces, one would think there ought to be differences in the enunciative traditions and practices that influence the cultural politics of black people in different spaces in Brazil. However, the nationalized activities of the movimento negro, a space for black cultural organizing, has always collectively identified all "black problems" under one political umbrella, which leaves very little room to distinguish between the cultural enunciations and practices of other black spaces in Brazil (Caldwell 2007; Johnson 1998, Santos 2006; Lovell 1999). Moreover, because the institutions and organizations around the country that are the faces of black culture during Carnaval and other large black social events, the bloco afros, all conceptually follow the musical styles and practices that come out of Salvador, most black spaces tend to emulate the enunciations produced in Salvador (Burcam 2004; Crook 1993, 2005; Dunn 1992 Béhague 2007). In practice, in response to statist discourses that seek to "whiten" black cultural productions, the construction of black identity in Salvador backed by the activities of the movimento negro and its engagements 
in black ethnopolitics has defined the essence of blackness or "Afro-Brasilidade" by "Africanizing" it. These processes of "Africanization" have been heavily tied to the pride of being of African descent and to the embodiment of an imaginary African performative produced outside of continental Africa itself (de Almeida 2004; Crook 1993; Dunn 1992 Béhague 2007).

Thus, the barometer for the construction of "Afro-Brasilidade" and black identity as defined in Salvador and emulated by others in different black spaces in Brazil has always been that of a conceptual negotiation where the cultural enunciative form cannot feed into the hybridized statist discourses or be "too white". In order for a cultural form to not be classified as not being "too white", de Almeida (2004) has argued that there appears to be a tacit agreement among members of the various sectors of the black community to weigh the cultural form against the possibilities of being able to "Africanize" it into a performative that can be embodied and commodified to economically help advance black productions. It is out of the ambiguity of this space of cultural economy that Afro-Brazilians produce cultural forms that allows them to coopt statist hegemonic discourses and also challenge them at the same time with counterhegemonic assertions of blackness, albeit black identity throughout Brazil being regional and segmentary (Pinho 2006).

What stands out in this project is how this production of challenging and contestation of statist hegemonic discourses of blackness can be seen differently in the context of roots reggae, an Afro-Caribbean enunciative form, and under the documentary practices of affirmative action. In order to show how roots reggae culture engages AfroBrasilidade Space, I trace the genealogy of the historical processes that includes the 
intellectual production of race, statist policies and culturalist movements that contributed to the construction of blackness in Afro-Brasilidade Space.

\section{Contextualizing and Conceptualizing Afro-Brasilidade Space}

Bulmer and Solomos $(1998,2004)$ have emphasized the social constructions of race and ethnicities, noting that membership in these non-natural groups are not fixed, neither are their boundaries. However, the material consequences for the inclusion or exclusion from these groups are reified such that they have impactful meanings on the foundations of identity formation. Consequently, in the lives of many people, the quotidian experience of race serves as a source of powerful sociopolitical categories that can also be best conceived as political and social resources because they are also generative of political struggle and agentive resistance (de Almeida 2004). Owing to the fact that race is a discursive formation, it is more beneficial to examine the racialization of a group as opposed to its reference as a racial group in order to point out that the category of race is in fact a product of racism and not the other way around. For this reason, Bulmer and Solomos (1998) have argued that the notions of race and racism are also fluid terms, such that the

subordinate groups may use difference to mystifiy, to deny knowledge of themselves to the dominant groups...to stress their own separateness, and to authorize their own representations...They may "seize the category," claim it for their own and invert it, attaching positive value where before it was negative (822-825).

My suggestion in response to Bulmer and Solomon' concept in the "seizing of the racialization" process by the oppressed group is that in the context of affirmative action policies, where there are contradictions between statist rights given and the documentary practices of the rights allotted, how the oppressed identifies with statist notions of ways 
of belonging are not fixed, as demonstrated above in how Baianos "Africanize" or "blacken" cultural productions. In this way, I suggest that the possibilities of the essentializing of black identities stems from Afro-Brazilians themselves in the agentive productions and reproductions of black identities in Afro-Brasilidade Space. This is seen in the trajectory of Afro-Brazilian responses to statist discourse concerning black identity through what I term as the "evaluator phases" of Brazil's hybridized discourses of racial democracy.

\section{Evolutory Phase One of Afro-Brasilidade Space:}

This first phase covers the Brazilian intellectual production from the $19^{\text {th }}$ century to the earlier period of the $20^{\text {th }}$ century. Here, as Schwarcz (1993) puts it, statist discourse defined Brazil through a "race" lens where, race was assigned a primodial and biological seat. Statist discourse paradigmatically employed European theories of evolutionism and racial determinism to denunciate the role of mestiçagem in the "racial degeneration" of Brazilian peoplehood (Assunção 1998; Agier 1995; Andrews 1996). Many others intellectually produced texts that simultaneously advocated the eventual deterioration of the nation due to racial mixture at the same time that it upheld the ambiguity of the myth of the tripartite races (white, black, indigenous) that could potential miscegenate to form the ideal mixture. Therefore, generally as a matter for sociopolitical stability, mestiçagem was viewed unfavorably; it was still conceived as a symbol of national distinctiveness that could be pushed as an imaginable solution for racial issues in the future. In these intellectual productions, the ways that the ambiguities of racial miscegenation could be "cured" was through branqueamento (to whiten the race). In engaging the various 
ideologies of Arianism, the goal was to "breed out" blacks, Indians and mixed race populations.

As Bucciferro (2015) puts it, the intellectual productions on race originated from the tensions to end the slave trade in 1888 such that the positivist colonial ideologies and anti-abolitionist reinforcements carried over into the racial struggles in the construction of the nation-state and establishment of the Republic. Through these tensions, the state and the Brazilian elite ensured that black popular culture that were deemed to have African origins were demonized. Black enunciations such as capoeira and Candomblé were criminalized under the guise justification that they promoted superstition and marginality within black urban population who had been ostracized from the workforce after abolition (Hofling 2012; Wesolowski 2007; Floyd 2019). Here, Afro-Brazilian dialogic responses to statist discursive persecution of black enunciative performatives were that of disguise and syncretism. The agentive ways of belonging in the new Republic as defined in Afro-Brasilidade Space was that of possibilities that incited creativity and innovatedness of black articulations and expressions that have their Africannity concealed in the effort to continue to have the space to produce and define identity. So for instance, capoeira was disguised as dance and some practices in some Candomblé sects were syncretized with European Catholic practices for survival and preservation (Assunção 2003; Floyd 2019; Talmon 2002).

\section{Evolutory Phase Two of Afro-Brasilidade Space:}

Gilberto Freyre and his Casa-Grande e Senzala (The Masters and the Slaves) published in 1933 defined this phase. With the establishment of the para-Fascist regime in the new Brazilian state, Estado Novo, Freyre defined statist formation in Brazil on the 
basis of nordestino engenho, which is the northeastern regional economy based on the colonial sugar plantation. He intellectually formulated a pseudo-serene image of Brazilian colonial society that had its foundations in the culturalist vision of patriarchy and Iberian familism (de Almeida 2004). Freyre portrayed Portuguese colonialism and cultural affinities to be lenient and open to miscegenation and the cultural expressions of African slaves. At the same time, he was a proponent of modernist views that was determined to conceal the explicit and implicit racism of the first phase, which was caught in-between the need to save the Republic from disintegrating due to miscegenation or to whiten the race to save it.

Araújo (1994) asserts that Freyre's Boasian education made sure he intellectually distinguished between race and culture and it also ensured that his views of national identity were caught within "the obsession and progress reason...could somehow be replaced by an interpretation that was focused on...the hybrid and unique articulation of tradition..." (29). Here, Afro-Brazilian Space was characterized by the possibilities of the mediation of blacks serving as cultural brokers. Slaves and their descendants found ways to produce and reproduce black enunciative forms that did not completely erase the African origins of their culture in the "whitening" processes of the state. It is at this phase that the new Republic popularized its ideologies of a "racial democracy" in contravention to U.S. Segregationism (ibid). This phase also begins the statist appropriations of the cultural forms of African slaves and their descendants that were coopted as national symbols of Brazilianness (Pinho 2006). De Almeida (2004) has argued that the areas of cooptation in the cultural manifestations of black people at this time were very specific in the areas of cultural activity that represented the "mystical, bodily, musical and sexual 
expressions" (20). I would like to highlight this point and its impact in Afro-Brasilidade Space. As aforementioned, in serving as cultural brokers that ensure that the Africanness of their cultural expressions was not completely "whitened" out, Afro-Brazilians found ways of recreating other cultural forms that emphasized the African origins of their identity expressions.

\section{Evolutory Phase Three of Afro-Brasilidade Space:}

As examined by Maggie (1993), during the early 1950s until the end of the 1960s and early 1970s, The United Nations Educational, Scientific and Cultural Organization (UNESCO) embarked on an antiracist project to examine the formulative components of Brazil's "racial democracy. The institution was interested in the nation's phenotypic and gradative system of racial classification that was based on pigmentocracy. This research project was originally designed by Arthur Ramos; a Brazilian anthropologist who was to carry it out in the state of Bahia but it was later extended nationwide (ibid). The end product of the research project led to a stark comparison between Brazil's phenotypic and pigmentocratic model of race versus the US's hypodescent one-drop rule. Moreover, the scholarly work that came out of this project as per the social scientists involved namely, Wagley in 1952, Hutchinson in 1952, Azevedo 1955, Nogueira 1955, Harris 1970 and Degler 1972, all failed to criticize and condemn the inherent social disparity and discrimination that were associated with the Brazilian model.

As suggested by Hanchard (1994), the predominant number of these scholarly assessments were pathological byproducts of race in Brazil or regurgitated versions of Freyre's ideologies as evidenced in the work of Harris in 1964 and Pierson in 1942 respectively. Contrastingly, Maggie (1993) disagrees with Hanchard (1994) by pointing 
out that although many of the scholarship at this time was disillusioned by the social realities of race, many other scholars DaMatta followed in later years that wrote about the social realities of race in Brazil.

DaMatta (1987), like his predecessors, does employ the Brazil versus US, "phenotype versus origin" model. However, what he does differently is that he proposes a reassessment of the Brazilian way of classifying blacks, whites and indigenous populations by examining the how auto-referential aspect of the Brazilian model in comparison with the dual model of the US. In Brazil, racial classification is based on the auto-referential point of how one perceives the other as lighter or darker relative one's self. Out of these classificatory systems three modes of categorizations were developed - the first system is based on romantic notions of the tripartite black, indigenous and white races; the second system is based on the everyday perceptions of others to self; and the third system came out the IBGE (Instituto de Geografia e Estatística - The institution responsible for national data and statistics) statistical census system, which classified the population along the lines of four main categories, negros (blacks), pardos (brown), brancos (whites) and amarelos (yellow) (Hanchard 1994). In these classifications, there was no dual classification that pitted black against white categories until the insurgence and activism heights of the movimento negro in the 1960s. At this phase, the dialogic response from Afro-Brasilidade Space to racial categorization, especially that of the official IBGE systems from was a political one. Based on the continued intellectual perpetuation of Freirean ideologies and the unremitting statist denial of racism alongside the decontextualized racial subjugation based on phenotype and pigmentocracy, the black social movements responded by 
clustering all of non-white issues under "black" issues as a political move against the idealizing of white supremacy in Brazil. Under this move, cultural and spiritual enunciations of all racialized groups had were "othered" by the social movements in attempt to fight statist discourse and practice as a united front.

\section{Evolutory Phase Three of Afro-Brasilidade Space:}

The influence of the movimento negro and other transnational black social movements in the 1970s transformed the conversations surrounding race. Hansenbalg (1979, 1985, 1995) and Hasenbalg and do Valle Silva (1988, 1993a, 1993b, 1995) asserted that racial inequality was a function of economics that served an indispensable function in Brazilian capitalism. Amongst other factors, an analysis of the census from the previous phase showed that whom one married or one's socioeconomic advancement in Brazil were based on the pigmentocracy and not cultural differences (Maggie 1993).

Based on these observations, Maggie has argued that descendants of slaves in Brazil cannot lay claim to ownership of what is deemed as black culture mostly because of how black identity has been constructed and defined. In contestation of statist discourse of racial inequality, Maggie argues that blacks reiterate blackness and black culture by ambivalently wavering in between the need for affirmation of black contributions to Brazil at the same time that they also seek a form of separate ethnicization that distinguishes black culture from the melting pot of Brazilian national culture, especially their affirmations are no longer perceived as beneficial. Maggie (1993) suggests that it is at this juncture of ambivalence that descendants of slaves no longer attribute what "black" is to the color of one's skin but as an ethnic "identity". Therefore, Maggie further suggest that because of the black population's ambivalence in deciding 
whether blackness to them is a pigmentocratic construct or identity/ethnicization, it is difficult for one to say that Brazilian hegemonic discourse concerning racial and cultural production has been based on the demonization of the African-rooted enunciations. My argument here in response to Maggie's assertions about ambivalence is that she fails to see that the black ambivalence to the construct of blackness is dialogic. As I discussed in Chapter 3, the white elite engages in an irreconcilable ambivalence in double narrative in how blacks are incorporated into its national discourse of racial democracy.

The seemingly paradox of shifting definitions of blackness as defined in AfroBrasilidade Space is in reaction or response to statist narrative in defining blackness. Afro-Brazilian concurrent reproduction as well as contestation of statist narratives of racial hierarchization inherent in the hybridized discourses of racial democracy is representative of the dialogic shifts and adjustments that Afro-Brazilians are forced to make in conversation with statist denial or acceptance of racism and racial discrimination in documentary practice of its hegemonic discourses on race. In the next section of this chapter, I engage in a brief discussion of the black population in Afro-Brasilidade Space have reproduced and contested statist discursive notions of blackness throughout these scholarly productions described above.

\section{Reproductions and Contestations of Discursive Representations of Black Identity in Afro- Brasilidade Space}

Agier and Carvalho (1994) have identified three distinct periods that mark the manifestations of black contestation as well as reproductions of statist hegemonic representations of blackness as accordance with the genealogy of Brazilian intellectual productions of race relations in Brazil. Firstly, Agier and Carvalho note that in the period 
following abolition, there was a mass movement that was prointegration in the 1930s, especially in the Southeastern cities of Brazil. The second period in the 1980s to the 1990s, is marked by the antiracist social movements of the 1970s, which called for the coalescing of all forms of black and Afro-Brazilian identity discourses. In the third period, which includes today's politics, it must be noted to blackness in Afro-Brasilidade Space was defined in reaction to statist discourse that clearly made a distinction between black and indigenous population. Although the indigenous population continued to remain marginalized in discourse and practice of citizenship, via statist policy they had been granted the status of ethnic "Other" mostly through land rights and record recognitions (Carvalho 2000, Valenta 2003, Schwartman 1996).

The black population was assumed to have been carved into the space of official citizenship after abolition and with the signature of Princess Isabel of Portugal as I discussed in Chapter 2. As such, the state in practice have not had to make practical changes as to how black identity is defined discursively and in practice. In response, in the space of defining blackness, Afro-Brazilians have had to define black identity through the cultural and spiritual productions as I explained earlier in this Chapter (See also Agier and Carvalho 1994). In Sousa's (1997) examination of this politics of citizenship and belonging, he asserts cultural productions marks the means by which the movimento negro have had to dialogically confront the juxtaposing discursive identifications with Brazilianness/Brasilidade (my own emphasis here), blackness and mestiçagem (113).

By adopting Sousa's arguments, in Afro-Brasilidade Space, the counter-discursive production of black difference has been concentrated on Africanization of black traditions and practices, especially music and dance practices and most significantly the 
expansion and bureaucratization of Afro-religious terreiros, and its associated practices. Cultural groups, such as the Baiano Carnaval Blocos of the 1970s who were dedicated to the countering of the negative face of blackness perpetuated by national discourse, formed the foundations of agentive power in Afro-Brasilidade Space. These institutions in various places around the nation have ensured the creation microcosms of cultural enunciations that counter official discourses that create fear and ideas of instability around black identity, black unity and solidarity and black embodiment of self-fashioning and representation (Agier and Carvalho 1994; 112). These bloco-Afro institutions have become the powerhouses that generates African-rooted and Afro-Brazilian mythologicalbased enunciative productions in the performatives of bodily aesthetics, music, dance, iconography, poetry, theatre etc., as it is conceptualized counter-discursively in AfroBrasilidade Space.

Moreover, these productions are performed in differentiated spaces of sociability that have come to be marked as particular black spaces (de Almeida 2004). For instance, since the inception of Salvador's afoxé Filhos de Gandhi ${ }^{30}$ in the 1940s, it was founded in clandestine $\mathrm{n}$ the Stevedore's Trade Union. The group later emerged in associations with Candomblé. Similarly, in the 1960s, the blocos de Indio ${ }^{31}$ they emerged during a time of immense urbanization and industrialization in Brazil, in connection with the Samba Schools. However, during the political renaissance of the movimento negro in the 1970s and 1980s, many of these bloco-afros emerged identifying with racial and cultural

\footnotetext{
30 Sons of Gandhi Afoxé

31 Indigenous Blocos are made up of mostly black members but during Carnaval parades they wear face masks portraying "indigeneity" in solidarity with indigenous groups, whom they believe should represent the original symbol of Brazil (De Almeida 2004).
} 
ties to Africanism as opposed to religious groups or trade unions. While statist discourse reinforced the denunciation of race and racism in the country, the bloco-Afros "reAfricanized" their performances in various ways to counteract national discourses of denial of racial realities.

The re-Africanization is evidenced particularly in 1974 with the founding of the Bloco Afros Ilê Ayê and Olodum in Salvador da Bahia (Agier and Carvalho 1994; Crook 1993; Dunn 1992; Perrone 1992; Scott 2002) Several others followed suit until the birth of the Movimento Negro Unificado (MNU) in 1978. The birth of the MNU changed the course and notion of agentive power in Afro-Brasilidade Space mainly because it altered the course of Brazilian racial politics. For the first time in the history of the birth of the new Republic, black activists and militants under the notion of "resistance" openly and publicly denounced racial inequalities and violence endured by blacks as well as the “accomodationist tactics" that had been used by other black groups (Hanchard 2018; 56). Hanchard (2018) notes that the organization of the MNU merged the various ...numbers of militant Afro-Brazilians with divergent regional, socioeconomic, and ideological backgrounds - to the consternation of white elites. Their activism precipitated coercive and preemptive acts by the state apparatus to repress Afro-Brazilian protest. The dynamic relationship between Afro-Brazilian protest and state-led reforms and controls led to new laws and social practices. It also led to new modes of consciousness for many Afro-Brazilian who discovered within the concept of an African diaspora racial self-identification and an awareness of other peoples and struggles (Hanchard 2018; 56).

Although today many blocos-Afros in association with the movimento negro are accused of the commercialization and merchandization of black culture, their ideologies and practices in regard to black cultural production form the basis of contestation and on 
occasion reproduction of national discursive ideologies that is sustains the productions in Afro-Brasilidade Space. As I discussed earlier, Afro-Brazilian cultural productions as such as music, dance, and religious practices as conceived in Afro-Brasilidade Space are tremendously based on embodiment and performativity.

Hanchard (1994) has argued that the notion of mestiçagem impacts the politics of Afro-Brazilian embodied performances in two ways, which is seen through the absence of power and culture. He states that the Freirean notion of culturalism ensured that blacks were assigned the role of cultural broker of expressive culture and what is deemed as embodied expressions of sexuality. However, because these same practices have been appropriated and labeled as national culture, the performance engaged in by the "experts" or "cultural brokers" of the "national culture" become fetishized or perverted versions of national culture. Hanchard argues that this process makes it difficult for one to distinguish between culture as folklore and culture as the basis of values for ethnopolitical action (Hanchard 1994; 100). So for instance, the re-Africanizations of various musical practices that constructed in Afro-Brasilidade Space in attempts to reclaim ownership or "positivize" the imagery of those practices will then prove lost in translation in conversation with national discourse that only sees the transformations as folklore in lieu of ethnopolitical action.

Consequently, Hanchard (1994) points to the significance that enunciations of the other black populations in the African Diaspora have had on the ethnopolitical conceptions of black identity in Afro-Brasilidade Space. He asserts that during the during the 1980s, Afro-Brazilian adopted and appropriated other expressions of black practices that were rooted in the early forms of pan-Africanism, into their own cultural 
productions, which predisposed them to mobilizing against statist discursive hegemony in a way that created a transnational identity or kinship among Afro-Brazilians with other persons of African descent ${ }^{32}$. The agentive initiative to mobilize gained from other Afrodiasporic spaces were adopted in attempts to counteract Brazilian racial hegemony that has always been rooted in the hybridized discursive ties to mestiçagem, branqueamento (whitening) and racial democracy. In order to deepen the discussion concerning the ethnopolitics of culture and the politics of identity that occurs in AfroBrasilidade Space in conversation with the discursive notions of mestiçagem, branqueamento, and racial democracy under affirmative action policies, I now turn the analytic of "cultural objectification" as delineated by Handler (1988).

\section{Culture Value, the Politics of Identity and Afro-Brasilidade Space}

In the examination of the politics of identity, Handler $(1988 ; 14)$ and Turner (1991), suggest that cultural objectification comes about when culture is seen as an entity made out of objects and traits. Accordingly, the "culture value" of its representation influences the processes that impact its negotiation in identity politics as one of value or of subordination. Handler (1988) asserts that the interconnectedness of "culture value" tied to the construction of national peoplehood that is rooted in the theoretical study of "race" is transnational in nature. Culture value is linked with the development, expansion and marketing of cultural goods. It is also connected to the modernization of the market of pleasure that is created by the industries that sell these cultural goods, as well as the

\footnotetext{
${ }^{32}$ See my discussion of Gilroy's $(1987,1993)$ of Black Atlantic influences and connections on Afro-Brasilidade Space in Chapter One
} 
inability and need for the modern nation-state to capably provide for the sustenance of all the materials warranted for the construction and representation of identity (ibid).

Deductively, it is the commodification of culture that assigns its value. If culture is a commodity, it assumes its objectification. So, for instance, as seen in the case of black cultural production in Salvador da Bahia, (discussed above), black musical practices that are modified and transformed in ways so as to appeal to the highest bidder in tourism in the name of economically advancing black culture in the region. However, in the instance where the same black musical practices conceptually, in Afro-Brasilidade Space are used as modalities of bargaining with statist discursive representations of blackness, the commodification of cultural production assumes cultural objectification on the part of the state. In the context of diverse cultures such as Brazil, where some cultural productions have been assigned "value" in national discourse and all others are seen as "folkloric" because they do not fulfill national sensibilities of what fits "peoplehood", there are no equivalences in value of all cultural performances or practices. Moreover, because racial hierarchization as a significant aspect of cultural production in Brazil has been rendered invisible and irrelevant discursively and in practice by the state, the value of the agentive or liberatory possibilities of dialogic responses in Afro-Brasilidade Space becomes incredibly important.

The agentive responses to statist discursive representation of blackness that emanate from Afro-Brasilidade space in the form cultural transformations and modifications are immensely "ethnicized". Yet, in the transnational Afrodiasporic space where the movement of commodified cultural goods transformed and appropriated freely, the practice of belonging to national peoplehood demands that one has to ascribe to one 
of several equivalent differences. Gilroy (1993) suggests how this process occurs in the political economy of the Black Atlantic, where ways of belonging and ideologies of cultural practices such as négritude, creolization, and pan-Africanism have always circulated. In the transnational circuits of the Black Atlantic, a common African origin; the diversity in colonial experiences that resulted from the interaction with particular European hegemonies; and the ethnic diversity that resulted from the various African origins factors into the formation of identities in this space. Furthermore, all of these factorial issues need to be accounted for in consideration with what Glissant (1997) calls the "returning to point of entanglements", that is the historical experience of slavery and how influences identity formation in the transnational sense (77).

In analyzing "culture value" within the context of transnationalism, how race is embodied and "ethnicized" in a political economy of culture needs to be discussed further. Guimarães (1995) argues that racial disparity and hierarchization have been naturalized in the political economy of Brazil through the concepts of pigmentocracy and class. Adopting Guimarães views, I suggest that the naturalization of racial disparity is paradoxical taking into the consideration that Brazil's national discourse of racial democracy denies racism while it forces an embodied cultural response out AfroBrasilidade Space that acknowledges racism. In this case, the embodiment of cultural practice and the naturalization of race engage in an "ethnicizational" politics of identity that are a result of the contradictions inherent in the relations of structural inequality grounded in statist narratives of racial democracy (Comaroff 1996). In Afro-Brasilidade Space, Afro-Brazilians ethnicize race by circumventing the structural realities of racial inequalities by creating cultural connections of kinship with other black people that is 
based on a projected common African origin. De Almeida (2004) suggests that because the concept of "ethnicity" has often been used only within the context of Western notions of nation-state to differentiate territorial or language barriers between groups, it is not often used to refer diasporic blacks in the Western Hemisphere. He insists that this is mainly because the general population of people in the Americas is not normally classified as having "different ethnic groups, especially within the same "race" (18). However, de Almeida (2004) argues that ...the interpretations of the African origin or the historical experience of the forced diaspora, slavery, and resistance, as well as the cultural production generated in that context are enough for the emergence of a collective ethnic mobilization. The fact it happens in a context in which there is a socially constructed perception and classification built upon an interpretation of the body may turn out to be a trap leading to reverse essentialism" (18).

Following de Almeida's argument, there needs to be a strategy in defining black identity in Afro-Brasilidade Space in order for it be counter discursive or "in order [for it] to be socially effective... [it would] have to give in to the cultural models of the day, not become paralyzed due to sociological skepticism, thus the emphasis on cultural forms based on the bodily arts by both dominant, defining powers, and subaltern social actors (ibid.). Here, in the Gramscian sense, the Brazilian racial hegemony is expressed through social mechanisms that simultaneously promotes racial discrimination and denies the existence of racial difference (Hanchard 1994). Additionally, with race operating as the mediator between social structure and culture, the dynamics of power relations ascribe meanings and practice that disparately impact the relations between groups. Consequently, the issue here according to Hanchard (1994) how to build counter discursive values using the current values without reproducing them under the new forms 
built; and also how to counteract the ideology of racial democracy that maintains that racism and racial disparity is not an issue at all.

At this juncture, my argument is that reggaeir@ and performative space in São Luis may be viewed as an example of a cultural enunciation that is counter discursive because it attempts to not use the current discursive forms of culture value. I suggest that the reggaeir@ performanscape does not necessarily invoke the same strategies in AfroBrasilidade Space as other black cultural forms have done historically in Brazil. In the next section of this chapter, with the help of vignette of a night out in the reggaeir@ performative space, I attempt explore the ways the reggaeir@ performative space simultaneously evokes and contests some of the culturalist practices of the movimento negro that has defined Afro-Brasilidade Space. As I have just discussed, the culturalist practices of the movimento negro may be viewed as a hindrance to the counterhegemonic political activities produced through cultural productions because they tend to reproduce the culturalist propensities inherent in the ideology of racial democracy.

Afro-Brasilidade Space provides the possibilities for Afro-Brazilians to reassign the "culture value" of their musical performance-scapes. Here, I discuss how the processes of "mixtures" or hybridization that occurs in the reggaeir@ performative space is produced out of Afro-Brasilidade Space, and yet the reggaeir@ performanscape allows reggaeir@s to agentively define blackness in differently ways than the dominant ways that other Afro-Brazilian performance spaces has defined it in Afro-Brasilidade Space. I also discuss how the "culture value" of the enunciative forms borne out of the reggaeir@ performance-scape responds to statist discursive notions of blackness. I also explore how 
reggaeir@ bodies embody cultural capital in these performative spaces that determine its "cultural value".

\section{The Reggaeir@ Performance Space: Mixing, Black Identity and Afro-Brasilidade Space}

"E ai galera! Tudo bem, seu corpo ta sintindo bem? Agora vamos trocar algumas coisas, viu? Vamos jogar com a intensidade das vibrações um poucinho, tá?" "What's good, people? Everyone doing good, bodies feeling good? C'mon let's change the pace of things a bit, ok? Let's intensify these vibrations a 'lil bit, yeah? Under the dim disco lights and the stench of beer mixed with sweat and other pungent bodily smells of the dance floor, DJ Jorge Black, with the microphone up very close to his lips hyped up the crowd with intense breaths between commentaries. He was getting ready to change the music but the crowd was engulfed in the rhythms of The Gladiator's "Looks is Deceiving" and so he kept it going for a few more minutes. A few dancers that had slowed their pace in reaction to the DJ's commentaries dove right back into their sways without missing a step. I was perched on the mini-stairs that led to the stage that held the DJ's equipment set up and so I took a quick glance over to the dance floor to take a few field notes for the night on my cell phone. In this space, on the dance floor in Rotatorio, on a Saturday night, the old danced with the young, women danced with other women, the middle class folks that had made their way to this part of town not far off from the city center, did not mind dancing with anyone from the periferias. After all on the dance floor, no one appears to care about which neighborhood the other person came from. 
I was absentmindedly singing along to the next track, "All of Me" a reggae rendition of John Legend's R\&B hit, when I overheard one of the group of young men standing near the speakers talking to my group of girlfriends about me. My clique of girlfriends who had invited me out that night, were enjoying cold beers in plastic cups placed on old wooden crates. They did not seem bothered by their questions and so they waved me over to respond to the casual inquiries myself. I was still singing out loud when I made my way to the girls. I walked into the series of questions the guys were asking, "Sua pretinha ${ }^{33}$ sabe todas as letras hein?" "Your homegirl knows all the lyrics huh?" This was in reference to my pronouncing of the song English lyrics with ease Within seconds of my arriving at the girls' seating area, they shrieked with excitement when the next track played and dragged each other to the dance floor to have their fair share of agarradinho for the night.

The girls had left me stranded with the group of men, and so at that point I had to singlehandedly face their rap and fire questions about what they perceived as my "perfect" pronunciation of English reggae lyrics. One of them, a tall, dark-skinned gentleman with dreadlocks and a loose black Bob Marley t-shirt turned towards me to ask in Ludovicense slang, "Tu é Maranhese?" "Are you a Maranhese?" "Sou, sim.” "Yeah, I am.”, I responded abruptly to end the conversation but he kept going. Most people do not

\footnotetext{
33 Pretinha or Preta could be interpreted as negra, black which would be the politically correct term to describe a black woman. As a term of endearment, especially in the northeastern part of country, pret@ or pretinh@(the diminutive form) is used amongst black people or used to refer to a deeply complected skin tone as mine. However, depending on the intonation and context within which the term is used, it could be prejorative term depending on who uses it and in what context. In this instance, based on the context, the young man was using the term endearingly. I translated this as "homegirl" because that would be the equivalent based on the context and relationships with the my group of friends.
} 
generally read me as American; often times I am assumed to be Angolana or Baiana and so as per usual he wanted to make sure. "Fala em serio, irmã!" he continued "seriously, "sister!"” At this point he was scanning my outfit as if he was checking for the stamp of my nationality approval on my shorts and t-shirt, that read "Trust me, I am a Nerd" on the chest. "Menina fala em serio!" "Girl, seriously!" I answered this time in the negative, assuring him I am not a Maranhese but I am no stranger to the city or that part of town for that matter. At this juncture, this young man had referred to me as "irma"("sister"- this appears to be a generalized termed used in black communities and Brazil) and "menina" ("girl"- often used amongst friends) within minutes. I assumed he felt comfortable enough with to continue his interrogation and so I played along.

People's attitude towards me often change when I tell them I am American and so I reluctantly specify if it is not necessary to the conversation. I usually go with Angolana or Mozambicana to avoid further questions about my accent in Portuguese. On any good day, I could not feign the singsong intonation of a Baiana or any other nordestino accent for that matter, even if I tried. Moreover, simply saying I am Angolan or Mozambican does not only make sense for my Portuguese intonation and it is what people expect me to be based on my dark skin and Afrocentric phenotypic features. This time around, I decided to be truthful as the topic was about my knowledge of English and my "expertise" in the correct pronunciation of all the lyrics being played.

The girls were back at their seats by the crates by the time the guys' began their next set of curious questions. They sipped on the beers and listened in on the further questioning; "E ai, voçê é Americana, que tá fazendo na ilha?" "So you are American, what are you doing here on the island (referring to São Luis)?” Before I could respond 
the stoutly built friend in the group joined in the conversation, "tá gostando, sei lá, tem nada chique aqui além do reggae, sabe" "Are you liking it here, I dunno, there's nothing fancy here aside from reggae, ya know". The whole group burst out with laughter at his sarcasm. One of the girls suddenly dragged me to the dance floor because the DJ had finally switched to robozinho, the electronic version of roots reggae played on the Island. The other girls cheered me on, "Vai menina, arrasou!" "Get it girl, you're killing it". This version of the roots reggae allowed more freedom for the dance to incorporate any dance style or bodily movement, and as per previous conversations with the girls; it was the perfect opportunity for the "American" to show her best moves.

Approximately fifteen minutes later, mid-track, three fully armed policia militar (PM) burst through the entrance door and based on the crowd's reaction, most people did not seem alarmed at all. The PM furiously dragged two black men standing by the door out as they furiously fought back. One of these black men practically got into a fist fight with the PM, while the other who was being help in quasi choke-hold managed to scream the words, "tô fazendo nada, rapaz", "I'm not doing anything, dude" amongst a series of expletives. Routinely throughout this fieldwork, these incidents usually marked my cue to end the night on the dance floor before things got chaotic for obvious safety reasons. However, this time around before I could make an exit, about six more PMs entered the building again blocking the door. They made their way to the stage to speak to the DJ. One whispered something to the DJ while the others sternly stood by the stage almost as if they were scouting for any retaliation from the crowd. The music had stopped at this point and so DJ B. got on the microphone and announced that the party had to end abruptly with no real explanation. Later, one of the girls mentioned that the DJ had gone 
past his "licensed time" ${ }^{34}$ that is why the PM came into the building. The girls and I managed to make our way outside through the now crowded front door. On our way out, I noticed as per usual, droves of PM squad cars parked in front of the building. On the other side of the street across the dancehall, a young black man was being tackled and violently kicked in the ribs by two PMs. Friend F, the self-appointed leader of our group, motioned for us to go the opposite way, away from the PM to get into a taxi. I tried to erase the memory of that poor black man being brutalized by the PM out of my mind. I thought to myself; as much I enjoy my dance experiences and socializing in these spaces, the nights always end very similar ways. As often as I could count throughout this work, PM Officers invaded reggaeir@ festivities and consistently brutalized members of this community and yet it appears as if most people in these spaces have begrudgingly come to accept it as part of engaging in these spaces. To an outsider, the frequent occurrences of these violent documentary practices by the PM may appear to have been normalized as part of the reggaeir@ space because people in these spaces almost expect them to happen. This is evidenced in how members of this community speak about them as "part of the reggaeir@life”.

In the taxi, I could not stop thinking about the night; this incident had been the worst PM brutality I had witnessed during my research. I snapped out of my thoughts to remark to the girls that it was only 1:00 a.m.; I also mentioned that to my knowledge reggae DJs were allowed to play sets until at least 3:00 a.m. Friend F replied, "never on

\footnotetext{
${ }^{34}$ To hold reggae parties, club owners and organizers of the even need to secure licenses from the city. These licenses are time-stamped, which allocates the time period in which the party can be held. From most interviews of various DJs, unlike other parties or concerts for other forms of music, licenses for reggae parties are getting increasingly harder to get due to the criminalization of the reggaeir@ spaces.
} 
this side of town but you can be sure the forró and the lil' pop parties in Litôranea will be allowed to go until day break without anyone bothering them. It is just us pretos, just us, sister (referring both to reggaeir@s and by extension the black community)”35. Unlike my friends that I frequented these reggaeir@ spaces with, I mentally found the normalization of the persistent PM brutality in these reggae events incredibly exhausting. It all seem so familiar, knowing well that unarmed black bodies in the US suffer similar violence at the hands of American police officers. And yet, it all seem as equally strange as a " black foreigner" that had become a part of this space; a space for black people who looked like me, a space that is laced with state violence and police brutality against black bodies who congregate only to engage in musical leisure and pleasure.

On our way home in the cab from Rotátorio, I reminisced about how energetic the roots reggae dance space is and how incredibly vast it is in accommodating a wide range of difference, at the same time that it opens up the space for kinship for black people. On the dance floor full of embraced black bodies swaying in a united front to the sounds that originated from a different Afrodiasporic space and lost in the mixed steps of rhythms and tempos of the Black Atlantic, performance of reggaeir@ismo as an identity is heavily corporeal and complexly physically embodied. The embraced bodies on the dance floor are made up of a mixed array of people from all parts of the island. As discussed earlier, the dance style of agarradinho is mixture of Caribbean styles, such as boleros, merengue, compas and forró amongst others. The music of roots reggae itself as experienced here on the island of São Luis is also mixed. Roots reggae here is a mixed Caribbean style that

${ }^{35}$ Litôranea is the upper and upper middle class neighborhood of town that is inhabited predominantly by white Brazilians. 
has been further rhythmically mixed with black British lover's rock at a tempo that suits the dance style of agarradinho. People smoothly sing along to the few Portuguese covers of English reggae songs, at the same time that they ruggedly butcher the English lyrics of obscure Caribbean tracks. My girlfriends and I, while in conversation in the same space easily throw in English words in conversations conducted in Portuguese, making mixed language conversation. The DJs' Portuguese adlibs to reggae soundtracks played in both broken English and Portuguese are also mixed and intertwined in this space. In spaces of musical practices and performance such as this dance space in the periferia, many barriers are being broken down, at the same time that new creations are being produced.

"Agarrado" as a regular verb in its literal sense means to be attached or hooked to something. On these dance floors, as the loud tempos that emanate from the stacks of radiolas around the dance space, bodies "agarra"-literally embrace their partners and the rhythms of the sounds. In the performative space of roots reggae on this island, the past participle verb, "agarrado" is no longer a verb connoting past action. Instead, it is a verb commanding action in the literal and figurative sense as it is transformed into a demand to being attached or hooked to the embrace of both a dance partner and the rhythms that create something new in each dance movement. "Agarrad'ing" commands a performance of the sway of the hips and the intricate movement of the entire body in this space for all sorts of people. In Butlerian terms, one can then say that the performances of agarradinho actively constructs the cultural space organized reggaeirismo. In other words whatever is being "agarra'ed" on the dance floor is "real only to the extent that it is performed" (Butler 1988, 527). What exactly is being, hooked, attached, mixed and created in these spaces? I suggest that what is being created is it quite possibly close to 
what Handler (1988) terms as creating "culture value". For each night that black bodies embrace each other on these dance floors, agarradinho is able to transform various interactions in this space that could not quite possibly be replicated in any other space but here. People from all parts of the city, country; from different social backgrounds, religious beliefs, educational background, gender, sexuality etc. all come together in this performative space to create meaning and kinship across difference. These are certainly hybridization or mixtures but what type of mixtures are they? Would one call it creolization and how do these mixtures factor into how musical practices are being produced differently in Afro-Brasilidade Space in contestation of statist hybridized discourses of black identity? What about the performative of agarradinho and its association with self-fashioning identity of reggaeir@ismo disturbs the state that drives it to violently interrupt its practice? I explore these questions further in the rest of the chapter.

In the theoretical discussions of creolization, racial hierarchization maintains an important position in understanding the concept as a whole (cite). Racial hierarchization offers the dynamic possibilities as well as barriers for conceptualizing the reggaeir@ performative space as a creolized space. However, the conceptualization of racial hierarchization also confines the generalizability of the notion of creolization to the discourse of cultural mixing in São Luis. I suggest that although the notion of racial hierarchization is critical to any understanding of creolization it also touches the imaginings and the pitfalls of analyzing the reggaeir@ performative space as a creolized space. I also suggest that the notion of racial hierarchization does not map on neatly with the germanence of creolization as a discourse of cultural mixing in São Luis. 
Through the conception of racial hierarchization, creolization has been seen as a process of loss, terror and deprivation (Verges 2015). As an overarching theme throughout this dissertation, I have discussed how the embeddedness of racial hierarchization in the hybridized discourse of racial democracy has very much been central in shaping Brazilian history, culture and society. However, as much as racial hierarchization has shaped the mixing of cultures in Brazil, it can also be evidently inferred that not all of these mixtures resulted from racial hierarchization. For example, as suggested by Benoist (1997), if creolization is understood to be a product of a milieu that is hierarchized that follows the master-slave relation, then it would be necessary to find other rationalizations to account for black-black intermixtures in Brazil. Hesse (2000) has suggested that the African Diaspora is a creolized cultural formation that is also a space marked by the intricate hierarchies of master-slave and colonizer-colonized relationships. However, I suggest that this conceptualization is problematic in the regard that it leaves out the moments in this space when relationships are cultivated outside of racial hierarchization as well as subordinate-colonized cultural interactions that are as equally important to the configuration of the process of creolization.

I would like to direct the reader back to the dancehall scene in Rotátorio; it appears that the lens of racial hierarchization would be problematic in signifying the various moments of cultural mixture in this space. As I document in earlier chapters in this dissertation, the mass emigration of descendants of slaves from rural Maranhão into the São Luis's periferias that mixed with other working class black populations from neighboring states such as Pará and other the Amazonas makes up the foundational population of reggaeir@s. This resulting hybrid population is made up of mostly poor 
working class black-black mixtures as well as poor working class black-indigenous mixtures. One would be hard pressed to describe these mixtures as resultant mixtures from racial hierarchization. Moreover, how else would one attribute racial hierarchization to the influence of other Caribbean hybrid musical and dance forms on the forms of selfrepresentation and meanings produced within the performance-scapes of agarradinho? Would one say that the musical influence of Jimmy Cliff, Johnny Nash and other African-American or Caribbean artistry on reggaeir@ cultural space be attributed to racial hierarchization as well? I argue that in these instances, there are immense drawbacks in employing creolization as a lens for mixtures that are products of alternative forms of racial differentiation.

It is imperative to note that here, I do not mean to imply that there are no hierarchies of any sort involved in these alternatives processes. After all, class, gender, sexuality etc. hierarchies intersect with that of race in these spaces. My contention then is with the essentialist scholarship of mixture there is a tendency to portray every hierarchization pertaining to race as that of subjugation, colonization, slavery and oppression. I am suggesting that the type of mixtures that is happening in the reggaeir@ performance space cannot attributed to racial hierarchization. Consequently, the analysis of these mixtures should be marked differently. In the cultural space organized around reggaeir@ismo, the notion of citizenship and national peoplehood as it relates to blackness touches musical practices as fundamentally different from the practices that are produced from the master-slave plantation dynamic. The hybridization that marks this space is not grounded or reliant on the mixing of black and white identity (processes of creolization) or white-indigenous identity mixings (processes of mesticagem, See Chapter 
2). Rather, they are mixtures produced within and between blackness and the influences of cultural productions that come out of other Afrodiasporic spaces.

Principally, Afro-Brasilidade Space and the cultural space organized around reggaeir@ismo are defined by moments of entanglements that are connected to musical practices. However, what I am arguing here is that the hybridity that is produced in the cultural space organized around reggaeir@ismo is produced out of another element added to Afro-Brasilidade Space that explains its transformation into a counter-discursive formation as I explore further below. According to Guilbault (2005), the possibilities that are produced out of the intersections of sociocultural relations are "audible entanglements."

These entanglements "foresound sites, moments, and modes of enunciation articulated through musical practices... [They] assemble social relations, cultural expressions and political formations" (Guilbault 2005, 40-91). She also argues that audible entanglements have the power to "render audible and visible specific constituencies and imaginations of longing, belonging and exclusion (Guilbault, 40). Accordingly, I argue that the "audible entanglements" of the reggaeir@performancescape are marked by moments of agentive creations between and through notions of blackness that may not be produced elsewhere but in that space. These moments allow for Afro-Maranheses to organize their black identity through and within the performative space of roots reggae music and dance, which is ultimately a part Afro-Brasilidade Space. However, the reggaeir@ performative space is different because it dialogically responds differently to statist discourses of hybridization through these entanglements. Moreover, my contention is that the mixtures produced through the reggaeir@performance-scape 
may not only be attributed to racial hierarchization. I suggest that the type of hybridizations occurring in this space and in this instance must be named differently for the reason that creolization discourse may not always be helpful as an analytic beyond the African-European racial entanglements and hierarchizations produced out of those moments.

It is then important to address scholarship where the notion of creolization has been defined differently beyond its generalized theory of cultural mixture that is marked by African-European mixture. For instance, Strauss (2004) has identified creolization as a non-inclusive the site of restraint where the creation of identity is characterized by a "painful process within which choices are often limited" (26). Contrastingly, Erasmus (2001) suggests that creolization in identity creation is specific to particular experiences that invoke cultural creativity that are shaped by histories of colonialism and domination. Here, Erasmus offers creolization as the way to critique the narratives of racial democracy as well as notions of essentialism. She links creolization to the notion of cultural labor taking into consideration the ways in which cultural enunciations are marginalized. Erasmus sees creolization as a process of "cultural dispossession, borrowing and transformation..." which leads to "a highly specific and instantly recognizable cultural formation — not just a "mixture" but a very particular "mixture" (Erasmus 2001, 21). She also suggest that the elements that make up the "mixture" are dominant cultural forms that have been "appropriated, translated and articulated in complex and subtle ways. These elements acquire their specific cultural meaning only once fused and translated (ibid). 
The way in which Erasmus employs the notion of creolization here is important to my analysis because to put it in Purian terms, Erasmus notes specificity the forms of mixtures that are involved and she acknowledges the importance of the local political history of the population that she studies. The scholarship of Nuttall and Michael (2000) theorize creolization as a concept that is helpful in describing the affinities that Afrodiasporic intimacy and affinities across difference. However, their theorization borders vagueness because it overextends the notion intimacy and affinity as capable of portraying all forms of cultural hybridizations with no limitations, unlike Erasmus. It is with this lack of specificity in the work of Nuttall and Michael that creates incredible pitfalls in addressing various types of hybridizations, especially in spaces of Afrodiasporic cultural contact that "do not lead to creolization" (Verges 2003:81). Of significant importance to this work in my analysis is the work of Hall (2003b), which distinguishes between the notions of creolization and Diaspora. Here, Hall (2003b) insists, "there are many different forms of intercultural intermixing”. However, unlike Nuttall (2002) who argues that creolization in some spaces germinated from meanings derived from "diasporic formation" and plantation slavery and its intersections with "race, space and mobility), Hall suggests a differentiation between how creolization and Diasporas are ideologically employed in scholarship. I find this distinction helpful in understanding the experiences of reggaeir@ musical practices.

I do see some significant differences between "diaspora" and "creolization. Diasporas are formed as a result of a variety of historical situations. Creolization, as it were, forced transculturation under the circumstances peculiar to transportation, slavery, and colonization. Of course, both terms describe societies where different cultures are forced to establish reciprocal relationships of some kind. But, in creolization, the process of fusion occurs in circumstances of massive disparities of power 
and the exercise of a brutal cultural dominance and incorporation between the different cultural elements. With diasporas, the process of cultural mixing is more varied. There is perhaps always an element of compulsion about it, but the kinds of compulsion involved are not the same. The outcomes are also different. (Hall 2003b: 186).

In line with Hall's distinction between creolization and Diaspora, my argument is that creolization (like mesticagem, see Chapter 2) does not map on well with the meanings and self-representation that are borne out of reggaeir@ musical practices under the institution of affirmative action policies in Brazil. I suggest that in order to understand the dialogic responses of the reggaeir@ cultural space as an "appendage" of the meanings of musical practices produced in Afro-Brasilidade Space, Diaspora better captures the intersections of the reggaeir@ affinity for other black musical practices and cultural hybridization. This is especially because "creole cultures are not about the mechanics of mixing, creolization is about a bricolage drawing freely upon what is available, recreating with new content and in new forms a distinctive culture, a creation in a situation of domination and conflict" (Verges 2003, 184). In this sense, creolization would be useful as a discursive theory of cultural mixing to describe some cultural practices under affirmative action police, however, it would be unable to illuminate moments of mixings educed on the agarrado dance floor as I describe above. As such, it may prove to be more useful to capture the type of mixing meaning produced in the reggaeir@ cultural space through the specificity of local histories of Afro-Brasilidade Space.

My conceptualization of Afro-Brasilidade Space argues for a Purian view of the specificity of understanding local histories and meanings to highlight the dialogic 
subjectivities of reggaeir@ performative space as a diasporic space. Moreover, in order to employ the analytic of Afro-Brasilidade Space effectively, it requires the need to examine local meanings of mixing that manifested beyond the actual performance of agarradinho. This especially important in demonstrating how Afro-Maranhese identity is organized through and within the performative space of roots reggae musical practices. In the next section of this chapter, I examine moments and expression of mixtures that extends above creolization.

\section{Agarrar, Agarrado, Agarradinho: The dialogic, Mixing and Diaspora}

Agarradinho performance-scape as I describe above does not derive its meaning from to musical mixtures, however, it also evokes space, ideas, identity, culture and expression in São Luis. And as a part of the production of Afro-Brasilidade Space it stands for the numerous possibilities and spaces of dialogic contact and difference. As discussed by Silva (2007), historically the city of São Luis has always lived its conflicts with regard to popular culture through the debate of what is worth of being deemed as “typically Maranhese”. Naturally, reggaeir@ culture has not been left out of this debate since its inception. What musical practices "belong" or do not belong in the state's imaginary becomes evident during the Carnival period and festas juninas seasons. Musical practices that have been adopted as part of Maranhese culture are given the liberty to demonstrate in all parts of the city during these festivities without having to experience violence from the PM. As interviewee DL addresses in her commentary, the PM surveillance appears to negatively impact only cultural spaces that "do not belong":

Here, the elite are very concerned about their reputation. You know, just like the old times. Not much has changed really. You know back in the day, they [meaning the elite] wouldn't let us into their dance or 
entertainment spots to listen and dance to their music. So we created our own, and now they also think what we have created isn't good enough to coexist in the same city as theirs. This is what all of this is about. It's about power, reputation, and control. They want to control what we have created and it kills them that what we have created makes us, our blackness and identity stand out. They have done the same thing with other black and indigenous things like bumba-meu-boi and blocos that do more African dances or black religious things. The elite create political blocks to make sure that these performances, leisure and entertainment don't become mainstream. There is a sort of disgust they associate with us and how we do these things, you know. So, it's simple, they make sure we don't have the space to showcase them. And if we try to do it anyway, they put things like license for space or simply send the military police to intimidate, hurt and even kill us. It's a disgrace, a disgusting disgrace! (Interview with the author January $16^{\text {th }} 2017$ in Centro Historico)

Silva (2007) expands on this interviewee's sentiments, suggesting that the politics of the culture of musical practices in São Luis, particularly between the elite class and the popular class has always been that of a geographical, spatial and social segregation. He explains, over the past decades as reggaeir@ culture became increasingly popular in the state of Maranhão to the extent of spreading to nearby cities, the city of São Luis, which was once known through its colonial times as the "Atenas Brasileira", "Brazilian Athens" became known as "Jamaica Brasileira”, "Brazilian Jamaica” or "Brazil’s Jamaica”. To the elite, Silva explains, this was a great loss over the fight to hold on to the state's "glorious" days of being known for its elite community of cognoscentes of literature, arts and sciences. Silva asserts the strong impact of reggaeir@ cultural on the city and its ability to change the cultural face and reputation of São Luis from its association with Eurocentric cultural values to Afrocentric or black-centric values meant for the elite a desecrating or tarnishing of the city's imaginary image. . This conflict is echoes by the statements of Ubirajar Rayol, a newspaper editor in O Jornal o Estado do Maranhão, on April $16^{\text {th }} 1991$, 
The "title" of "Jamaica Brasileira" does not please the Maranhese elites who see in the title an affront to the past of "glorious" writers, poets, and essays that made São Luis known as the "Atenas Brasileiras" centuries ago. The moment that the Maranhese medias re-labeled São Luis as Brazil's Jamaica, the elite saw this as a reduction of in the city's reputation, a deplorable abuse. The ignominy of reggae seems to have infected the city, desecrating its culture and blotting out its past of literary and artistic fame (Silva 2007, 32 translated with author's emphasis.)

Here, I would like to refer the reader back to the historiographies and evolution of reggaeir@ spaces around the city of São Luis as detailed in Chapter 2 of this work. When reggaeir@ dance spaces began to sprawl around the city, by innovation and as a result of being excluded out of white elite dance spaces, the elite eventually began to associate reggaeir@ related events with broader sociocultural and political agendas to the reggaeir@ community these space were as just spaces of leisure (Silva 1995). This is mainly because as popular as the performative spaces of reggaeir@s became, it provided a space in the state's cultural imaginary for especially the young black lower class population of the periferias to seen without the need of white elite cultural spaces. Moreover, the reggaeir@ space increased the visibility of reggaeir@s and its association to black in the city, which redefined their spaces as territories of black mobilization even if they were not initially politically intended to be viewed as such. This tension goes back to the debate surrounding the cultural politics to define what belongs in Maranhão's cultural ideals. In the same way that black and indigenous cultural enunciations such as Bumba-meu-boi (boi) and other Afro-centered religious practices have had to fight to be considered "traditional" or "local" in the realm of Maranhese popular culture, reggaeir@ activities face the same dilemmas against the elite. For example, in the case of boi (see chapter 2), the acceptance and rejection of the cultural performance and manifestations of 
its activities by the elite and more affluent classes of the Maranhão during the June cultural festivities really depends on the places the performances are practiced. So, during the festas juninas, boi and other cultural enunciations have been assigned particular geographical locations for performances. Throughout the years as boi became more accepted as part of Maranhão's cultural topography, the performances gained center stages in the city's historical center with members of the elite in attendance. The surveillance by the PM at this particular event in the city as I witnessed numerous times focuses on protection and security. However, on June $30^{\text {th }}$, known locally as the day of São Marçal that closes the Juninas celebrations, when the same groups of percussionists and masquerades gradually descend into the periferias with their performances, and the entire face and energy of the city are changed with colorful performance-scape of boi, the documentary practice of protection by the PM switches to violence. This, as I have observed is not necessarily due to the performance changing or the population engaging in the performances changing but to the PM's inability to control geographically where drumming and dancing can occur. In the same vein of Silva's (2007) assertions, in the process and moments of descent of the percussion groups into the periferias, the elite in their absence no longer control what the face of boi's performance-scape looks like as the elite would have it in the state's cultural imaginary. Hence, the way to control it is by the brutal activities of the PM. My argument is that the reggaeir@ performative space suffers this same pressures for control as the performance-scape of reggaeir@ culture continues to transform the cultural imaginary of the city of São Luis and by extension the state of Maranhão. In the final section of chapter, I briefly examine some of the events and activities that define the dialogic responses of the reggaeir@ performative space to the 
tensions of control of the Maranhese elite. I show how these responses can be seen as part of the dialogics of the Afro-Brasilidade Space to discursive ideologies of the state. In the next chapter, I explore these activities in detail with instances I term as "situations".

\section{Reggaeir@ Bodies in Motion: “Caribbeanizing” Afro-Maranhese Identity in the}

\section{Reggaeir@Performative Space}

Most reggaeir@s have no tangible connection to the realities of life in Jamaica or the Caribbean. In fact, as you may already know most of us don't even speak English and so we don't understand any of these lyrics. What we know about the Caribbean and roots reggae music, is what was brought to us through traders, through traveling musicians, through the radio and the bit of what we see in the movies and television. What we have made of reggae culture in this part of the world is what we think other black people in the Caribbean do with it. Our attachment to the lyrics is in the feeling and the rhythms of the sound. We feel the music like Jamaicans do and we can all relate to the pain of what all black people feel through the sounds. It's like the rhythms connect us, you know? Our ancestors were slaves just like theirs and so it makes sense. We are all one people from the big source that is Africa. I must admit one thing, the first time I visited Jamaica, you know, I was shocked to see people, the Caribbean in Jamaica do not dance agarradinho to reggae music. I mean, this should not come as a shock to me but it was, you know? It's just that when I think of reggae, I think black rhythm and I also think agarradinho automatically. It's like the ocean and sand. We got the clothing and the hairstyles right but the dances, no, no not the dances (J chuckles). But that's good too that we have created something special of our ourselves from the gift of music that our Caribbean brothers and sisters have given us. (Interviewee J, Neighborhood of Fatima, Interview with the author on February $5^{\text {th }}$ 2017)

The above statement from one of my interviewees speaks on many levels to the types of connections and affinities that reggaeir@s create with other Afrodiasporic spaces such as the Caribbean. The statement also speak to the moments of creations that happens in the performative space that informs the dialogues produced out of Afro-Brasilidade Space. Firstly, J speaks to connection between São Luis and the Caribbean that is through sonic entanglements. Although most ludovicenses are not familiar with the lives of 
Jamaicans or other black Caribbean people, reggaeir@s throughout this work shared with me connections that appear to have been created through imaginative moments in their own productions via dance and leisure. These connections that reggaeir@s recount are narrated to appear as in fact to be similar to that of the original inventors of the reggae sound that is Jamaicans. In other words, although reggaeir@s recognize the language barriers between Caribbean black folk and themselves, they have imaginatively assume a role for the rhythms of the sonic connections they share such that the sound and rhythms play an intricate role in the perception of their affinities to other Afrodiasporans in the Caribbean. As seen in J's statement, the sounds of roots reggae are equated with dance and the assumption is that the sound serves the same functionality for the other black people in Afrodiasporic spaces in the Caribbean. It is for this reason that $\mathrm{J}$ was surprised that Jamaicans do not dance in the ballroom style of agarradinho as it is done in the city of São Luis. Nevertheless, J insists on the affinities to Caribbeans even if the dances are different. To him, the sonic connection remains the same it is only different in its translation in performance of the type or style of dance.

Throughout my research, in interviews, in informal conversations, in observations and in personal experiences, I noticed reggaeir@s imaginatively create routes to connect their own experiences to Jamaica by "Caribbeanizing" their experiences just as other black spaces in Brazil "Africanize" their productions and performances. As I discuss above, this appears to be a distinct performative feature of Afro-Brasilidade Space, where blackness is defined by attaching what is imagined to be "African" to forms of musical enunciations in order to set it apart from other productions. Similarly, reggaeir@s in the performative spaces of São Luis appears to be following similar performative productions 
and connections except that in this instance the connections are not imaginatively "Africanized" but "Caribbeanized". These forms of enunciative performances are seen in instances such as everyday reggaeir@ language; and so for example the use of terms such as "Jah RastafarI", "rude boy", "ragamuffin", "dread" "black power", "Babylon” etc. amongst others are often invoked in speech yet none of this performative use of these terms bear any real relation to the meanings associated with them in Jamaica or the Caribbean. For same performative reasons, in language, reggaeir@s incorporate these words in everyday “reggaeir@ speak" in order to identify oneself as being associated with the reggaeir@ community but not because anyone in the reggaeir@ space is committed to the Rastafarianism as religion or practice.

The same can be said for dress and hair performative in these spaces. Many reggaeir@s wear dreadlocks and adorn their hair with cowries; they also commit to wearing "black liberation" colors—red, green and black, attires with Bob Marley or other Caribbean artists as well as colorful netting attire that is often seen in reggae dancehalls in the Caribbean. The interesting aspect of these performative attire is that the styles and color are worn only to the dancehall spaces. Consequently, one may be to conclude that all of these enunciative performances are borrowed and transformed for the temporal musical enunciations that occur in the reggaeir@ cultural space. However, I suggest that reggaeir@s do not borrow, adapt and transform Jamaican performative culture blindly although it may appear as template productions of the original. Instead, I suggest that these performatives in the reggaeir@ cultural space, Caribbean musical and cultural practices are invoked to agentively produce the notion of assertive blackness. The reggaeir@ cultural space allows reggaeir@s to agentively employ the global circulating 
products of other Afrodiasporic spaces through the local interpretations of Afrodiasporic blackness that is mediated through agarradinho dance in reggaeir@ spaces. I suggest that the reggaeir@ cultural space provides the space for reggaeir@s to cumulatively translate their borrowed cultural practices and products of Jamaica and other parts of the Caribbean, mixing it with their own productions to create identities that are selffashioned that responds to the exclusions from modernity and spaces as defined by white elites. In the reggaeir@ space, poor working class people occupy a space of leisure that allows them claim ownership to their own modes of dressing, speaking, and expressing themselves in ways that seen as a distinguished from the exclusion and silencing of their identities from white elite spaces. The tensions between the elite and the black population concerning the reggaeir@ performative space touches the "culture value' (as discussed above) that elite attribute to the performance-scape of reggaeir@ culture. The Maranhese elite perceived culture value of reggaeir@ performative spaces stands in tension with its view of what traditional "proper" Maranhese culture should be, making it counterdiscursive to elitist constructions of black identity. This explains the motives of the elite's control as evidenced in the violence policing of reggaeir@ cultural space.

In sum, this chapter has examined the production and inner workings of AfroBrasilidade Space. It has also explored the counter-discursive creation of the reggaeir@ space that was produced out of necessity; necessity that arose out of white exclusion of the São Luis' working class black population from the periferias from white spaces of leisure. The exclusion from white spaces of leisure meant that lower working class black populations had to create their own. However, the enunciations produced out of these black spaces are viewed as counter-discursive as they challenge the discursive ideologies 
of black identity as defined by white elites. This self-fashioning of reggaeir@ black identity has also been expressed in other areas outside of dance, these includes areas such as politics and community organizing that extends beyond the performative cultural space. In the succeeding chapter, I explore in "situations" further nuances of cultural mixings that may not be based solely on the products of hierarchizations as theorized by scholars of creolization. I show in particular examples how the reggaeir@ performative space is invoked dialogically differently in Afro-Brasilidade Space in response to statist discourse.

\section{Moments in Reggaeir@ Spaces of Belonging and Afro-brasilidade Space}

In this work, I have argued the need to understand the processes of hybridity in their local contexts, instead of abstracting them into generalizable principles. This is especially the case when examining musical practices such as root reggae in São Luis. I suggest that as scholars of performance and performance spaces, it would be more helpful to examine various historical events and processes that interact with the specificities of the local contexts that contribute to the embodied performances and by extension the production of the performance space.

In this chapter, I build on my analysis of the "rhizomatic" experiences of reggaeir@s from the previous chapter and how they have been shaped by the historiographies of São Luis do Maranhão through an ethnographic study of reggaeir@ismo (Deleuze and Guattari, 1980). Here, I explore localized performative specificities and situated understandings of the processes that shape reggaeir@ performance identity, musical and dance practices. Particularly, I present ethnography that shows that entire counter-discursive performance space organized around roots 
reggae musical practices, contributes to the definition of Afro-Maranhese identity that extends beyond the actual performance and performative space. I suggest with these ethnographies that the Afro-Maranhese identity is organized through and within the performative space of roots reggae music and dance. Specifically, I examine reggae and dance scene in clubs, open enclosed radiola spaces, concerts and community organizing meeting and the politics surrounding it to explore the embodiment of reggaeir@ismo.

In Purian terms, how localized specificities interact with statist discourses of hybridity as manifested in the documentary practices of the surveillance of reggaeir@ spaces is captured in the moments of quotidian experiences in these spaces. I analyze these specific moments that create how reggaeir@s embody and demonstrate the different ways of belonging in São Luis. From a traditional Marxist culturalist perspective, these moments of destabilization for the most part are not transformative in terms of deconstructing social hierarchies. However, I contend that these moments of local specificities are significant because racism, violent policing against black bodies and the criminalizing of black spaces remain significant in Brazil under affirmative action policies. As such, for reggaeir@s who experience these modes of oppression on daily basis deem these moments as valuable and important. Consequently, the policing and the documentary practices of violence against black performative bodies must not be only be highlighted in grand abstract ideas. It is important to note that I am not suggesting that these moments capture the entire picture of what it means to experience all that there is to experience in reggaeir@ spaces. Rather, I intend to give the reader a glimpse into how these moments of deconstructions are created. It is important for the reader to note that these moments that I will be describing are loaded in that they produce meaningful 
outcomes that are invaluable to reggaeir@s. It is through these outcomes that reggaeir@s are able to imagine alternate ways of being and belonging. 


\section{VI: Chapter 5, Localized Situations and Rhythmanalysis}

According to Carlson (1996), performance is imbued in everyday-embodied practice, which are portrayed in the looks, gestures, movement, glances and so on. Moreover, Lefebvre (1996) in his notion of rhythmanalysis suggest that one way to understand the urban space is by assessing its rhythms. Consequently, understanding the significance of a performative space is to understand the "rhythms" of the embodied practices and its components "move" and "intertwine" in the performative space. In order for the reader to understand the very fabric of the performative spaces in the city of São Luis, it is important to understand the interior and exterior rhythms of the performance space - dancing agarradinho; the responses of the chants and hype of DJ on the dance floor; the silent "clinks" of beer-filled plastic cups in the noisy corners of the dance floors; the nonchalance to the stench of urine and sweat on the dance floor; and the sluggishness of slippery feet and embraced bodies sliding across gunk-filled floors to loud music blasting from gigantic radiolas around the island at any moment in time. It is as equally important to understand how the "rhythms" of the dance extend beyond it to impact community organizing and political races in São Luis.

Lefebvre's "Rhythmanalysis" helps us to process the relationship between body and its movements in the urban space. Lefebvre (1996) defines "rhythmanalysis" as:

The analysis of these multiple rhythms [that] enable us to verify that the relation of the townsman to his city (and area)...does not consist only of a sociological relationship of the individual with a group. It is on the one hand a relationship of the human being with his own body, with his tongue and speech, with his gestures, in a certain place and with a gestural whole, and on the other hand, a relationship with the largest public space, with the entire society and beyond it, the universe" (235). 
I borrow Lefebvre's term to show the significance of paying attention to these practices as they are embodied in the everyday, especially in the performative space and how these practices of "rhythms" relate to each other. Because reggaeir@ismo is visual, aural, and tactile in performance, it is better experienced that recounted. Hence, I connect the borrowed term of "rhythmanalysis" with a variety of "rhizomatic" moments I term as "situations" to help the reader to visualize, hear, and feel through the ethnography of the quotidian in São Luis. It is important for me to note that while I use the term "situations" as an analytical tool in my ethnography, I do not share the cynism that Situationists ${ }^{36}$ attribute to the political implications that is attributed to consumer cultures. On the contrary, I use the term to highlight the valuable moments of embodied practices that are fundamental to my analysis.

\section{Situation 1:}

\section{O Reggae é Agarradinho: The Reggaeir@ Space, Dance, Self-Fashioning and Leisure}

I introduce this situation to explore the interior "rhythms" of the reggaeir@ dance space and its relationship to ways of belonging in São Luis do Maranhão. I focus on the differences between embodied performances in the periferias and tourist or middle class

\footnotetext{
${ }^{36}$ The idea of "situations" comes from a group of Marxist scholars who avowed the strategy of engagement as "constructed encounters and creatively lived moments in existing urban setting that could produce modes for the transformation of the city" (Lefebvre 1996,12). Lefebvre (1996), in the application of the term, used the term broadly: "it could be applied to individuals and groups or to the world as it affected all people. Therefore, for example, modernity was a situation and not an essence. Meanings stem from and feed into situations" (ibid).
} 
spaces. I use this situation to highlight the mixtures that are being produced in the performative space.

"Let's start you off with a nice tourist club first. I recommend you ease your way in...you know just like dancing agarradinho--you start slow until that moment when the DJ puts on a good "pedra ${ }^{37,,}$, Then bam! You feel the beats, the rhythms, you really feel it, your head spins a little, you sweat a little and you are relaxed because obviously by then you've had "algumas" “a few"38. You won't even mind adding some of your American "hippie hoppie" "hip-hop" moves to agarrado then. You can do what you want you know. That's just how it is.” As I attempt to put on my second pair of sandals, Ribamar ("Riba"), my gatekeeper in the field and research associate, a self-professed reggaeiro since childhood was giving me a pseudo pep-talk as to where we should start and how to conduct myself on the dance floor.

For some reason he was still convinced Maranhão had not rubbed off on me yet even though I had been in the city for two weeks at that time. He had suggested we go to "Chama Mare" first and then "Bar Nelson, Centro" followed by "Bar Nelson, Litoranea"39, which were all dance spaces that catered more to tourist or the middle class population. I found his commentary amusing because he felt I needed to be "initiated" into the reggae scene as an "American". I eventually finished putting on my sandals and was ready to go. Riba felt he had to inspect my clothes. I wore a simple blue jean short,

\footnotetext{
37 Maranhese slang for popular hit song often used in reggaeir@ spaces 38 Referring to cups of beer. I have chosen to keep some the words in our conversations untranslated because I feel it captures the sentiment of conversation much better.

${ }^{39}$ Bar Nelson has two locations, they all appear to cater to tourists and
} 
white blouse with a cross-body purse. He did a quick up and down glance at my clothes and commented, "I know I said it's touristy but your shirt is too "nice". Just in case we end up in the periferias at the end of the night. I mean anything can happen, ya know." I was getting impatient with Riba's indecisiveness, not so much at having to change my shirt three times before we headed out of the door, but more so at him constantly referencing my Americanness as if it mattered. On our way to the car, I asked him why he kept referring to my nationality. Riba chuckled and said that for the most part he was just merely pulling my legs because he could tell I was anxious. But also he was in part serious because he did not want us to "chama atenção" "draw too much attention" if we ended up in the poor side of town.

I felt more so ill prepared for the exploratory part of my fieldwork. It was my second time in São Luis since my last visit in December of 2011. During my last visit, I frequented a few reggae bars then but because the Carnival Season in São Luis kicks off immediately after the New Year, I did not get to experience much of the reggae scene on my two-week stay in the city. I had always thought I would "fit right in" as a deep darkskinned black woman in a predominantly black reggae spaces. I was right, without speaking to anyone I did not stand out. As noted by Riba's comments, my blackness was not enough to pass as a reggaeir@, especially in the periferias. Reggaeir@ismo as you can tell by my gatekeeper's comments was not just about dancing agarradinho; it called for a way of dressing, speaking, dancing and interacting that were particular only to those who know it well. 


\section{Chama Maré, Bar Nelson Centro: The Reggaeir@ Space Through the Lens of}

\section{Tourism}

For our first stop we ended up at Chama Maré, a beautiful beachside bar in Ponta D'Areia, Litoranea (see photos CM 1 through CM3). The neighborhood of Ponta D’Areia, which later became my place of residence years later when I returned to São Luis, is made up of mainly middle class and upper middle class white population. The bar owner, AD was hosting a special event that night so we were met at the door by an allmale "ushers" in well-pressed dress shirts, bow ties and black pants. There were also three male and two female security guards at the door who inspected the crowd's pockets and patted everyone down for safety before waving them into the front door. After going through security checks, most people went to a cashier seated right behind the door to pay their entry free. Fortunately for me Riba knew practically every bar owner, including Ademar and so he got into most places for free.

He pointed to the cashier that I was with him and so she waved both of us in. I asked Riba how much the usual cover cost for Chama Maré. He said it was $\mathrm{R} \$ 15.00$ but for this special event it was $\mathrm{R} \$ 20.00$. I asked him if that considered reasonable for a place like this. He responded with, "for the middle class and tourist people, yes. But for people like our people (referring to the black population), no. For the first time, Riba was not referring to me as an American but as skin-folk. I smiled and repeated "our people" back to him. He nodded and smiled back, responding, "yes, “our people”, especially after dressing the part, I officially baptize you as Afro-Maranhese". I accepted my unofficial 
ushering into the Afro-Ludovicense ${ }^{40}$ kinfolk on this side of the Black Atlantic. I tried not to bask too long in the sentiments of his statement of acceptance in this instance where my blackness was enough to fit in because I knew there were more instances to come where I would not fit in. Later in my research, I came to understand that "our people"black people, in reference to cover prices and Chama Maré's location meant a great deal for the type of crowd that were often found in places like this one.

As noted in Chapter 2 of this dissertation, the monthly salary of the average black worker is about five times less than the average white worker in São Luis. On an average, the weekly earnings of reggaeir@s from the periferias is less than $\mathrm{R} \$ 10.00$. There are no direct bus routes from slum neighborhoods to this part of town. In order for a person in an impoverished neighborhood in Liberdade for instance to arrive in Litoranea, it takes about 3 bus connections to get there. Moreover, the hours of the bus schedules are limited. The majority of the bus schedules stop running around 8:30 p.m. for perceived high crime rates on the buses after these hours. However, reggae venues like Chama mare are normally opened from 9:00 p.m. until daybreak. Consequently, for the most part, party goers stayed in their own neighborhoods unless they had their own modes of transportation, which is often not the case for most people from the periferias.

${ }^{40}$ Ludovicense is the name given to residents of the city of São Luis. 


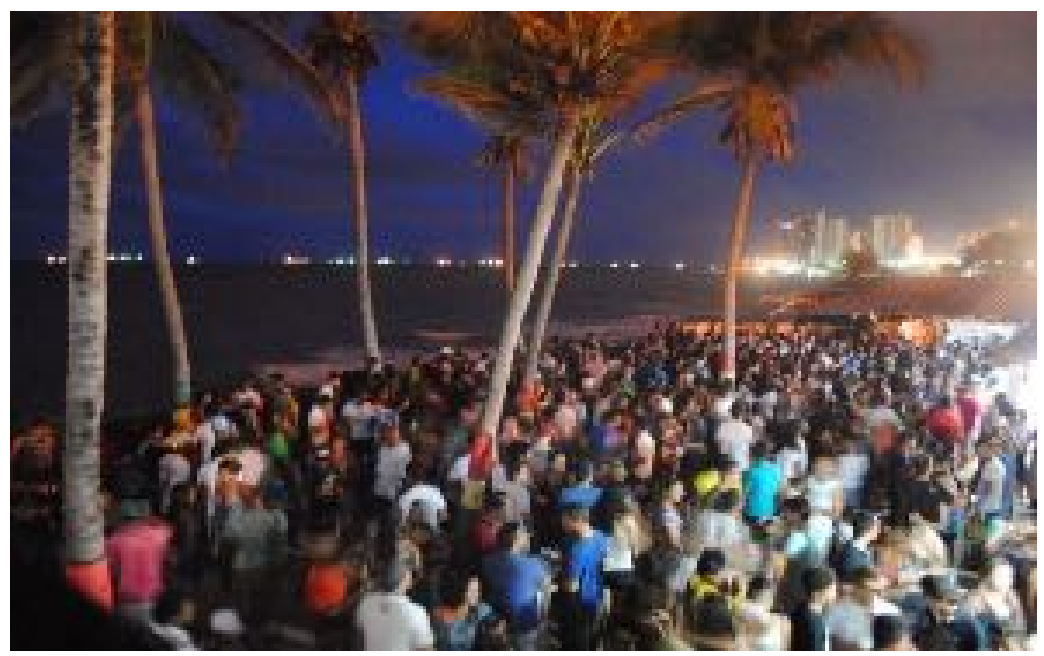

Photo CM 1: Crowded beachside dance floor at Chama Mare (taken by Ribamar Nascimento)

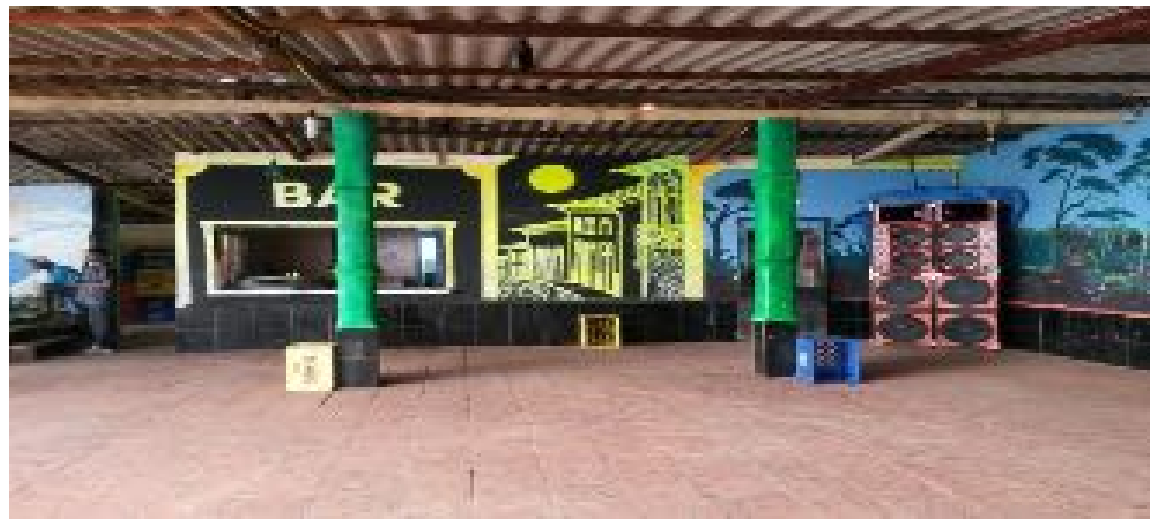

Photo CM 2: An empty dance floor and stage at Chama Mare (taken by Ribamar Nascimento) 


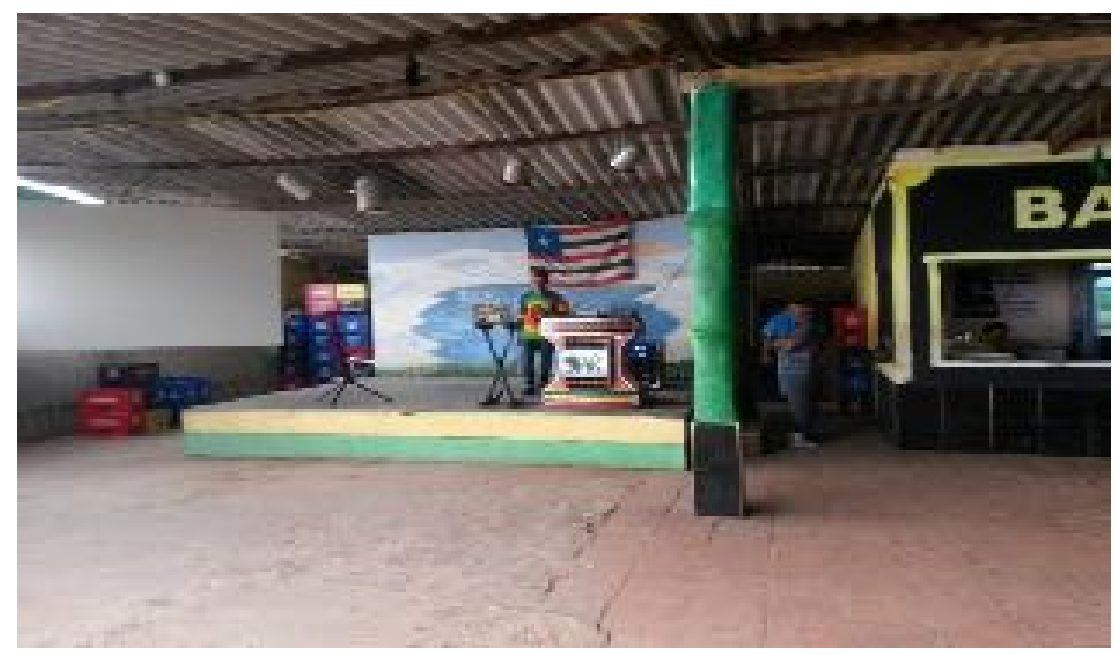

\section{Photo CM 3: A pre-setup stage with DJ equipment at Chama Mare (taken by Ribamar Nascimento)}

Chama Maré is located near the home base of one the massive sound system, Super Itamaraty. Tonight, Super Itamaraty and its DJs were hosting the party, and so as it was expected, they drew in quite the crowd into this quaint beachside dance space. As expected, the majority of the crowd were young white and mestiço people dressed in relatively more expensive clothing than what you would see in a periferia.

At 9:00 p.m. when we arrived, the party had already started and couples were swaying on the dance floor in their best agarradinho moves under the breeze of this moonlit beachside space. The floor was incredibly packed with not much space to move around. Riba, my 6'4', 280lbs gatekeeper had managed to squeeze his way to the stage to greet the DJ, a short and stout mestiço man who had already started his set for night. Three more DJs were to follow Mr. B's set for the night. Riba, towering over the crowd, waved me over to the stage to make the acquaintance of Mr. B.

I pushed past a middle aged black man dancing with a skinny white brunette and another mestizo young man swaying reckless across the dance floor with a tall, heavyset 
blonde twice his height. By the time I made my way to the stage Mr. B. had passed on the set baton to DJ N. who had dropped the pedra, "The Wailing Souls". The crowd went wild and screamed making my efforts to get to the stage area quite the feat. Riba insistently motioned for me to stay put for a bit to have the crowd settle. In the next five minutes or so DJ N. played "Jah Jah Give us life to live", "Natty Rebel" and "Screaming Target". At the end of that set, I finally pushed my way to the stage, relieved. I started to pay more attention to the crowd and the space. Practically everyone in Chama Mare was dancing, some not very skillfully but quite enthusiastically nonetheless. As per usual, practically everyone was engaging in what I sentimentally termed as "ceverja leisure" "beer leisure" in this space. All over Brazil, in places of leisure, be it homes, restaurants, bars, parks, street events etc. there is a nationwide cultural practice as I have consistently observed for people to often to share the company of others by drinking German-style light pilsner beers ${ }^{41}$. The brands of these beers are not limited to Skol, Schin, Itaipava, Brahma etc. On this night at Chama Maré, things were no different; most people engaged in cerveja leisure while they took breaks from the dance floor, often congregating around clear mini plastic cups on tables or makeshift drink stands made from beer crates. Most people bought their beers from the Chama Maré's bar instead of heading outside for cheaper options for fear of not being let back in into the establishment.

While the crowd waltzed away in um parte ${ }^{42}$, several people retreated to the sands on the beach itself to smoke spliffs of marijuana. As observed throughout my research, smoking marijuana (which is illegal in Brazil in general) in the open in reggae spaces like

\footnotetext{
${ }^{41}$ According to ranker.com, Brazil ranks as the fourth largest beer market in the world.

${ }^{42}$ Local slang referring to dancing to music with a partner.
} 
Chama Maré that catered to the middle class and tourist crowds was the unspoken norm. Unlike the dance spaces in the periferias, people where the police and security guards aggressively monitor the behaviors of everyone, the crowds at Chama Mare are free to smoke marijuana and engage all sorts of illicit recreational drugs without anyone batting an eye. Around 10:30 p.m., the DJ's changed sets again. The next DJ started his routine by playing tracks by Linton Kwesi Johnson, Matumbi, and some reggae cover versions of Rod Stewart's “I am sailing” and Nielson's “I can't live". Surprisingly, the crowd went wild for these tracks and several people who were hanging on the beach came back onto the dance floor to continue dancing. For the rest of the night, I lingered around the bar for a while and returned to the stage area around 11:00 p.m. Riba suggested we head to Bar Nelson in Reviver (the historic center) for our next stop.

Upon arrival, we went through the same security routine to enter the bar. Unlike, Chama Maré, Bar Nelson, which is in the historic center used to be in one of the old colonial homes that have since been turned into a bar (see photos BN1 through BN4 below). Like Chama Maré's crowd, it comprised of mostly tourists from other places in and out of Brazil who were visiting the city, some for the first time. The two-floor dance space was larger and very well decorated. The ceilings were fitted with the glitz and glamour of disco lights. It had better furniture and well-kept bathrooms. There is an actual demarcated dance floor unlike Chama Maré that used the entire space as a dance floor. 


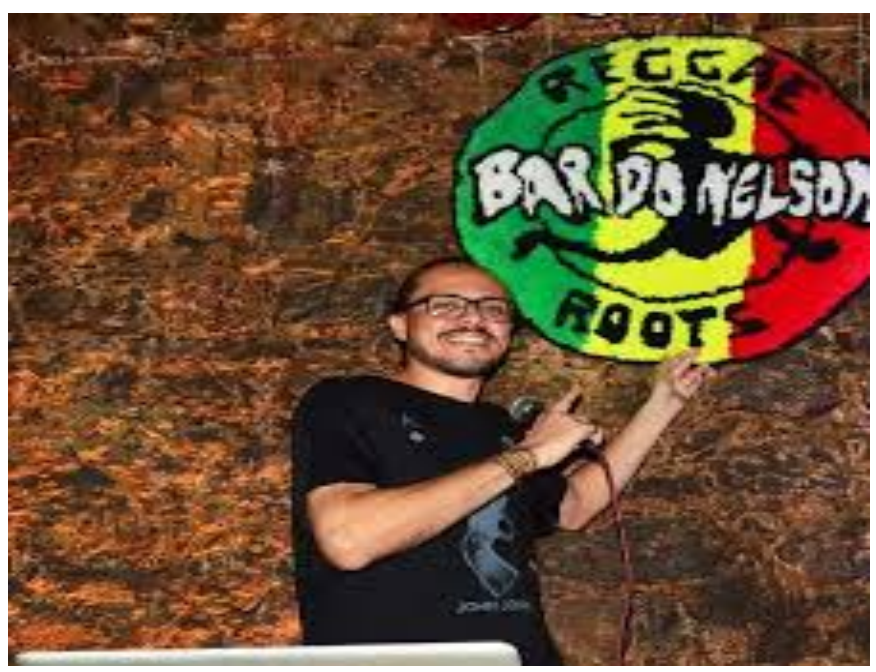

Photo BN 1: DJ during a set at Bar Nelson Centro (taken by Ribamar Nascimento)

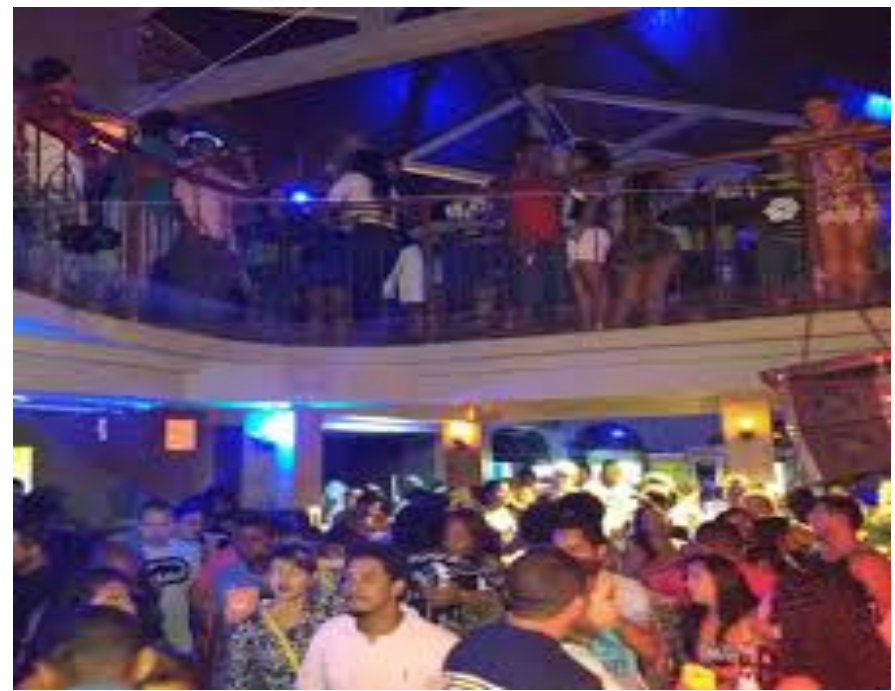

Photo BN 2: Crowded dance floor and seating area at Bar Nelson Centro (taken by Ribamar Nascimento) 


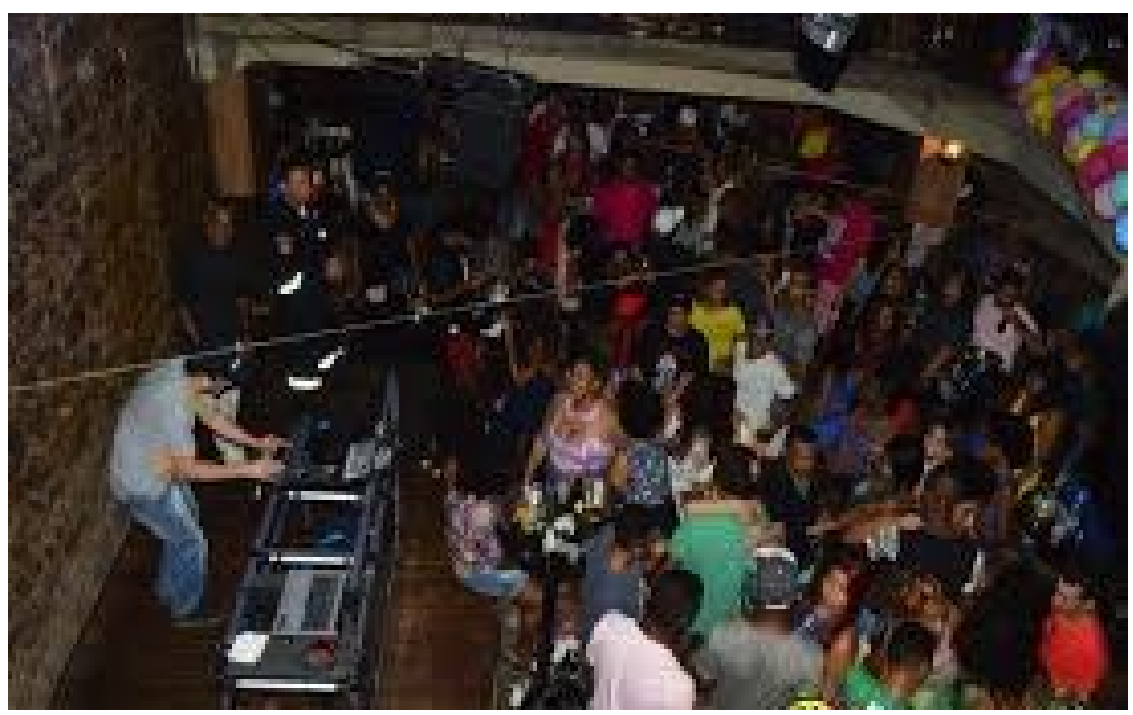

Photo BN 3: Crowded dance floor and DJ at Bar Nelson Centro (taken by Ribamar Nascimento

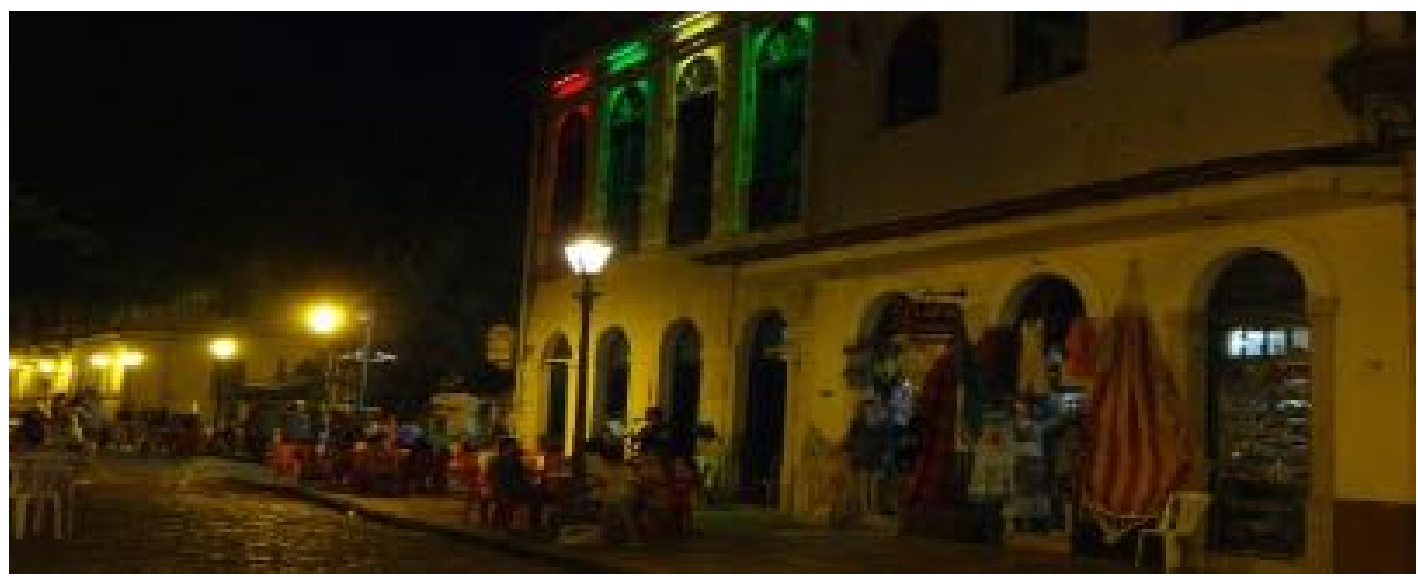

Photo: BN 4: Outside seating area at Bar Nelson (taken by Ribamar Nascimento 
The DJ played very similar songs as Chama Maré and the crowd danced in embraced agarradinho style as in most spaces. The DJs here varied by race and but they were all male. The mixed-aged crowd at Bar Nelson stood out to me. Although the crowd were more racially diverse with slightly more black people in this location than the last, it was very divided by age and class. Because of the central location of Bar Nelson, a decent number of people from the poor parts of town had managed to make their way there while the buses still ran at the earlier part of the night. The older crowd mostly sat outside at tables arranged across the side streets in front of the bar, engaging in cerveja leisure to chat the night away. Everyone was very well dressed and extremely stylish as well. All the black women in these spaces had Afro hair and a few wore wrapped turbans around their head.

The dance floor was mostly full of the younger women, who cheered and jeered when the DJ switched from the lover's rocksteady style of reggae to an electronic version of reggae known locally as robozinho. The majority of the people on the dance floor were young women and most of the couples dancing were women as well. I was later informed that there tend to be more women couple dancers in spaces that play robozinho. The embraced style of each couple varied greatly_-some women held the back of their partner's neck or head. Others were wrapped up in each other's arms while dancing cheek to cheek. It appears that black women felt freer to express themselves on the dance floor here. ${ }^{43}$

43 The analysis of the various forms of agarradinho and robozinho is beyond the scope of this dissertation, and so most of my assessment of the dances will remain ethnographically descriptive. See (Yawson 2016) for such analysis. 
A few minutes later the DJ played another set of robozinho. This immediately prompted the few older people on the dance floor to join the others at the tables outside. I lingered around the dance space to watch the dances, especially the robozinho style, which the young Ludovicenses have incorporated what I perceived as kizomba-cum-hiphop into the usual agarradinho form of ballroom partner dancing. From my research, I learned that older reggaeir@s who want to adhere to what they perceive as the "real" roots reggae style, often repudiate the younger crowd that prefer this electronic version of roots reggae. I dawdled outside behind a few of the older people 'escaping the sounds of "robozinho" to one of the crowded tables. Riba came to find me outside a couple of minutes after midnight to head to our next stop. At this point I was incredibly exhausted but the few minutes rest outside helped me get back on my feet. "How can you be sitting?" Riba remarked. "The night is just getting started. If you want to transform into a true reggaeira, you would need to dance, drink and interact with others all night, which is the true reggaeir@ lifestyle” he muttered amidst intense chuckles, as he perceived my level of exhaustion on my face. He informed me I was ready for a "real" reggae event in the periferias. "Enough of this "coisa do brancos" "44, "white people things". What you have seen so far is what the city official have dilutes our culture into. This is what they show the tourists and other people not from our ends of this city to make them feel comfortable. Let's go experience what real agarradinho and real roots reggae is like with our people".

On our way there, Riba gave me a bit of history of Bairro de Fatima, the periferia in one of the roughest areas on the eastern part of the island. We were headed to Point

44 "White people stuff", referring to reggae spaces we had been to thus far. 
Celso Cliff Club (known locally as Celso Cliff) in a predominantly poor black neighborhood. I asked how "safe" it was to go this area of town at that hour of the morning. Immediately after I asked that question I thought to myself how that question fed into the city's creation of "comfort" reggae spaces for tourists. I also thought about how my perceptions have been impacted by the discourse of terror and crime surrounding reggae. It is worth mentioning that I was genuinely concerned about my safety as foreigner if I were to "stand out" in a high crime poor neighborhood. Riba assured me that we were safe as long as I did not carry any valuables on me.

I had been taking notes and pictures on my iPhone the entire night so he advised me to put my phone in cross-body purse and to keep the purse in front of my body at all times and not one the side of my hip as I had been doing throughout the night in the other locations. He then told me to tie the hems of my blouse into a side knot to expose a bit of my midriff. I joked around saying, I almost feel as if we were heading to a gentleman's club. Riba clarified that he was trying to make my outfit look less "expensive". He then repeated his statement from earlier before we headed out the house, "our people are lovely but poverty is a real thing and we don't need to "chama atenção" "call attention to ourselves". It is better you blend in". Riba's commentary put me a bit on the edge much to my chagrin, and so to my great surprise and relief upon arrival to Fatima, I had absolutely nothing to worry about at all. This made me content and disappointed at the same time as I felt I had indeed being influenced by the general discourse of crime surrounding reggae. 


\section{Celso Cliff and Agarrahinho: Style, Self-Fashioning and Leisure}

The Celso Cliff club is a multi-room dance space that has its walls covered with colorful Jamaican, Maranhese, Ethiopian and Black Nationalist flags. The walls are also painted with all sorts of words like, "freedom", "Jah", "Babylon" etc. in graffiti. The DJ was already playing a couple of sets and so part of the crowd were already busily swaying on the dance floor while many others spilled out into the street to share 40 -ounce Artic beer bottles in clear plastic cups. The energy and vibe in this space was incredibly laid back and different in comparison to the other spaces I had been in earlier that night. People hung out like they were in each other's homes. Although many were dressed up, those from the neighborhood itself were very much underdressed and in very cheap clothing. There were as were as many men reggaeiros of all age groups as there were women. Most of women wore shorts and those in other forms of clothing exposed some portion of their torso. This observation suddenly made Riba's dress code advice seem more reasonable. The men wore vibrant black liberation colored shirts with shorts or pants. Additionally, both men and women in this space had all sorts of hairstyles, from Afros, to braided styles to dreadlocks. Most people here carried themselves with so much pride that was palpable in their sense of fashion (see Photo CC4 and CC5 below).

The atmosphere at Celso Cliff carried more of a neighborhood bar vibe than a club (see Photo CC1 below). The chairs in there were mostly benches and the music played from computers attached to smaller speakers as there was no large radiolas as you see elsewhere in the middle class spaces. Everyone was incredibly friendly and they all seemed to be enjoying themselves, including a group of male cross-dressers that hung out by the vendors selling knick knacks such as gum, candy, and cigarettes right outside the 
club's entrance. The dancers here moved on the floor with incredibly skillful passion; the movements were intensely effortless and unbelievably stylish in comparison to the last two spaces we visited. Everyone on the dance floor seemed immensely talented by his or her own right; there was no denial I was in the birthplace of agarradinho. There were very few female couples and no male couples; the majority of the dancers were malefemale couples. Unlike, Bar Nelson, there were as equally as many men dancers as there were women. Again, the style of embrace in the agarradinho varied from person to person. It was hard to tell who real-life couples were and who were not because the level of bodily intimacy between every couple on the dance floor was just as intense between each couple. Some women placed their hands around the male partners' neck, some held on to the male partner's shoulders and others locked fingers with their partners on the one hand, and then switched the other hand sporadically from the male partner's neck to the waist depending on how the male partner led with the movements (see photos CC2 through CC3 below).

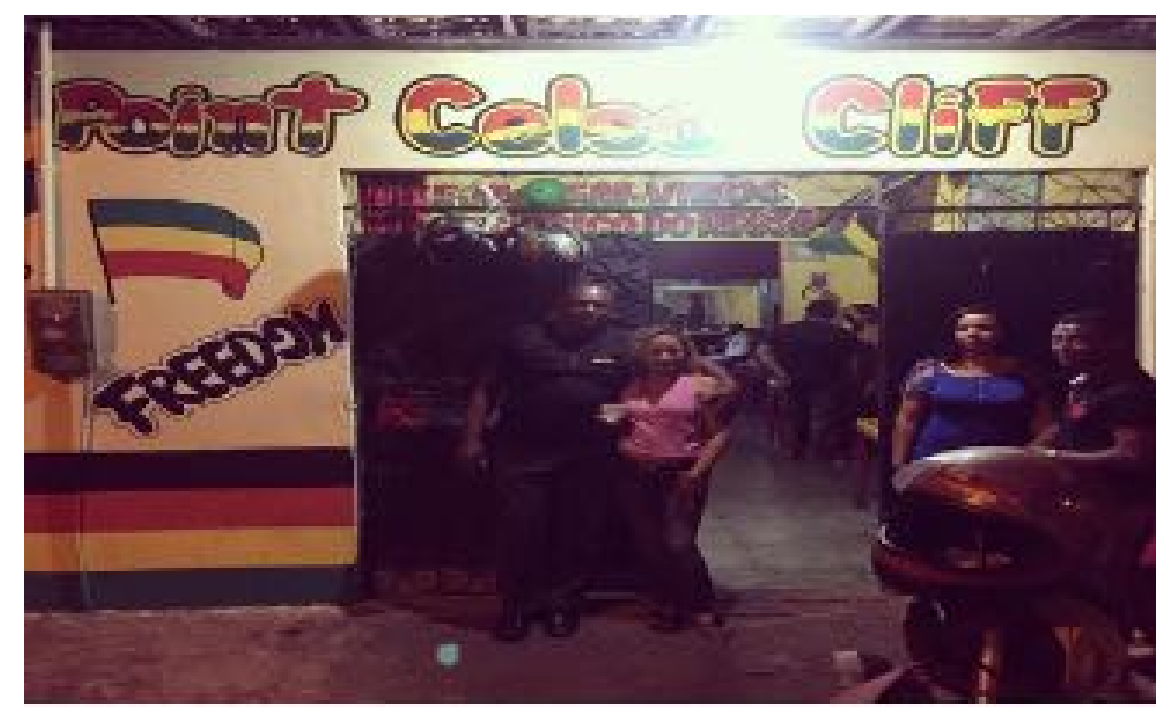

Photo CC1: Couple at the entrance of Celso Cliff Point (Picture taken by Ribamar Nascimento) 


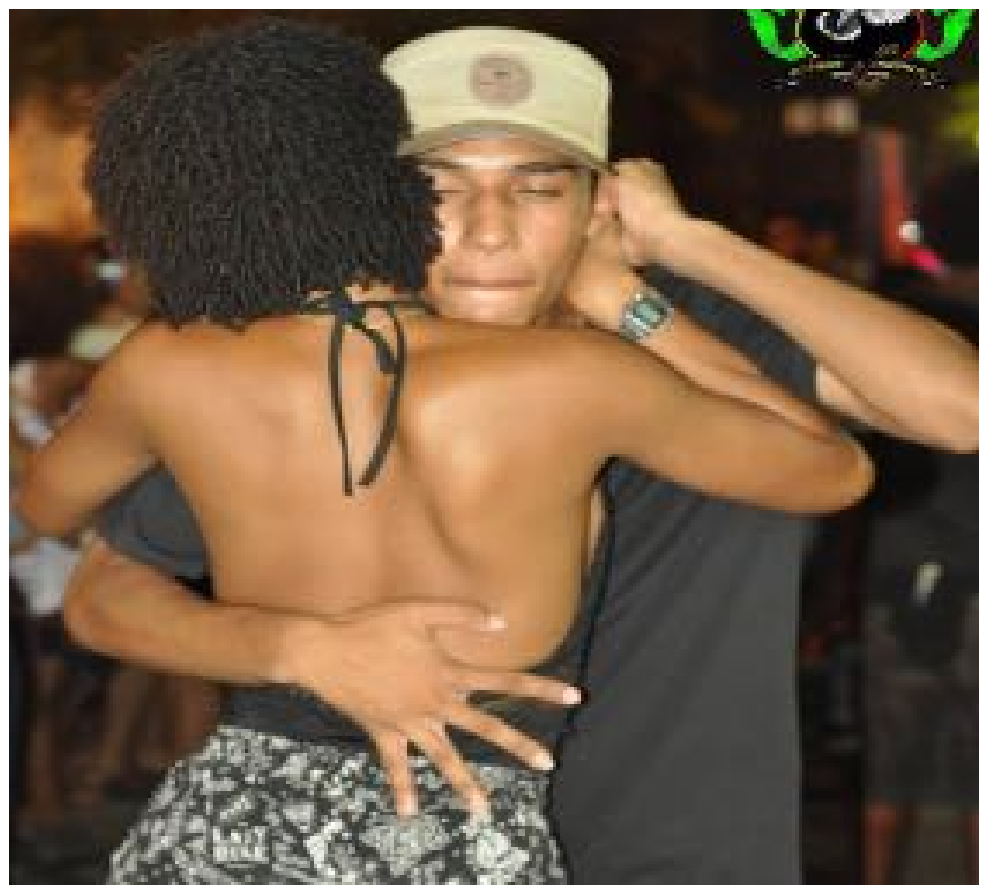

Photo CC2: Couple in dancing agarradinho at Celso Cliff Point (Picture taken by Ribamar Nascimento)

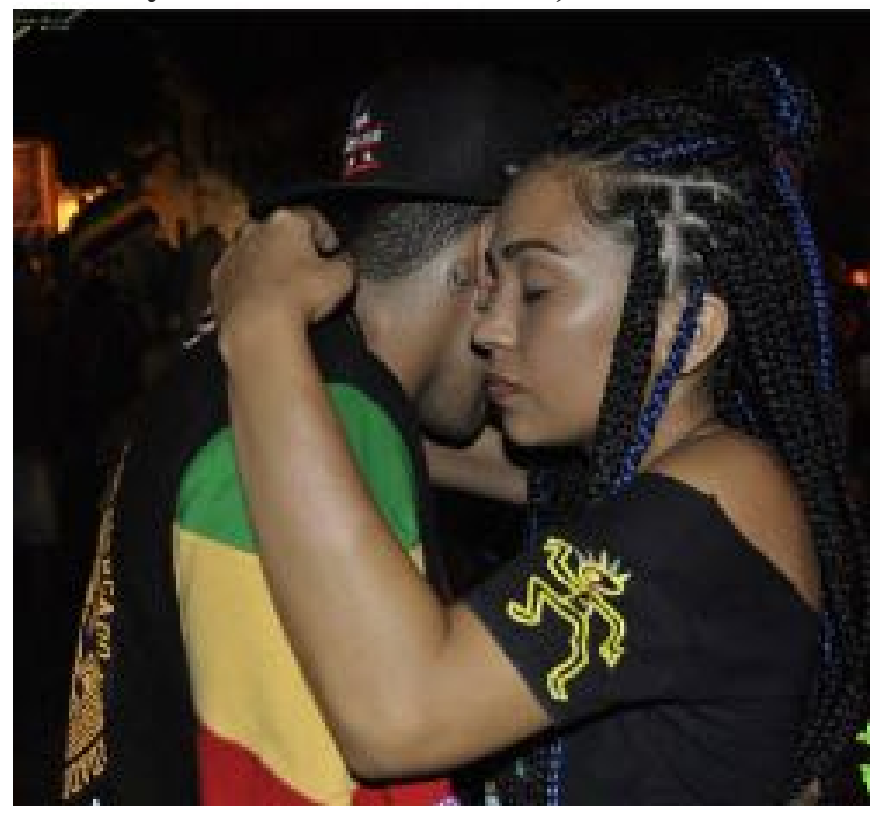

Photo CC3: Couple in dancing agarradinho at Celso Cliff Point (Picture taken by Ribamar Nascimento) 


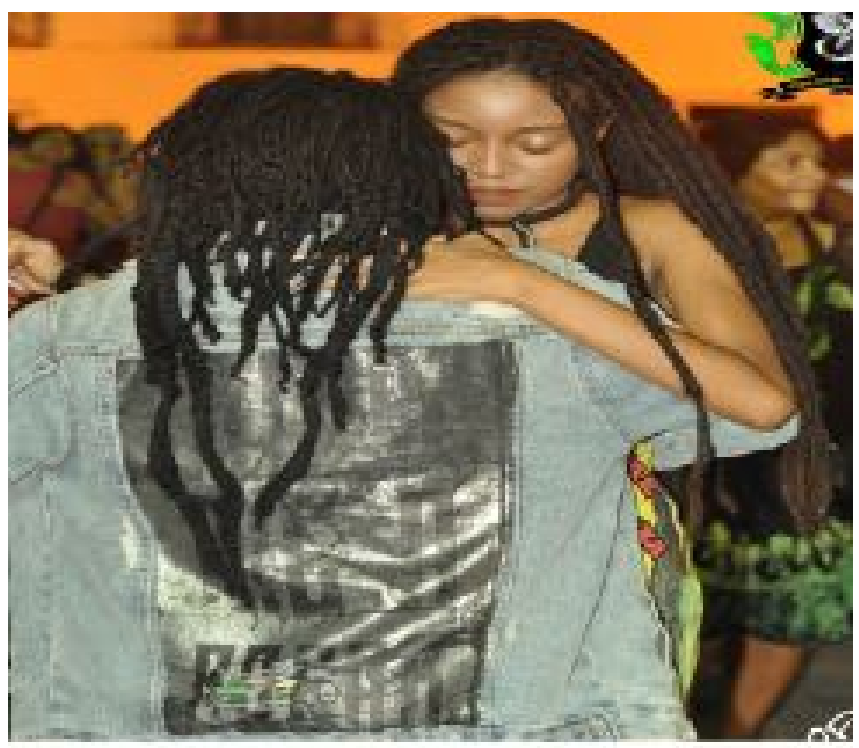

Photo CC3: Couple in dancing agarradinho at Celso Cliff Point (Picture taken by Ribamar Nascimento)

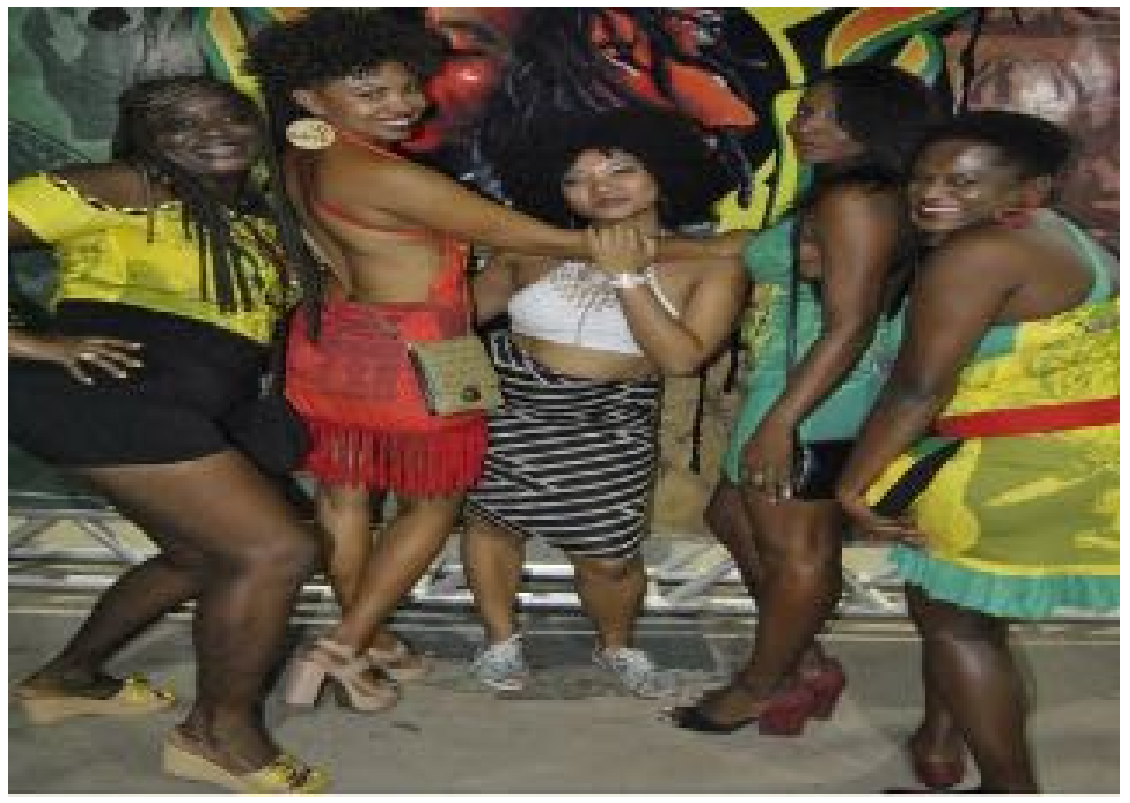

Photo CC4: Women fashionably dressed in colorful clothing from the neighborhood of Fatima at Celso Cliff Point (Picture taken by Ribamar Nascimento) 


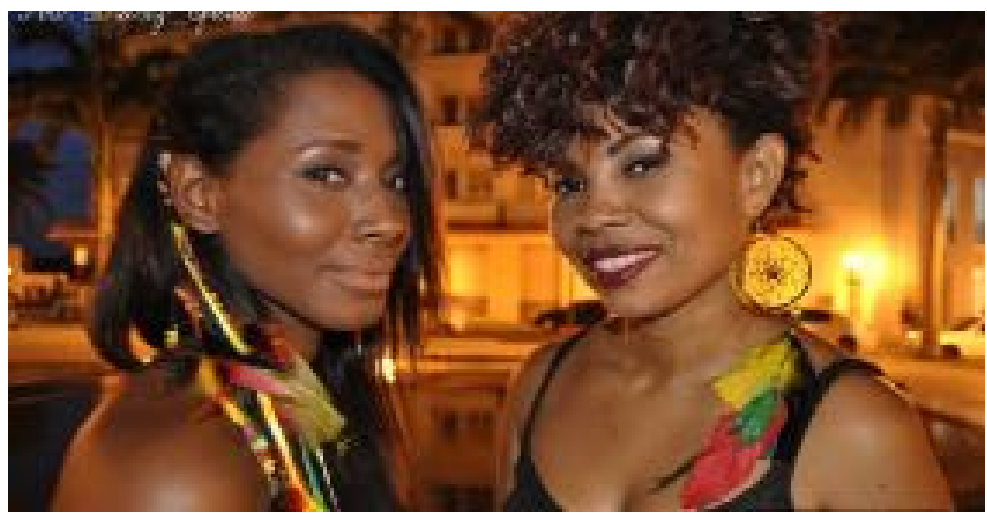

Photo CC5: Women fashionably dressed in colorful liberation colored earrings from the neighborhood of Fatima at Celso Cliff Point (Picture taken by Ribamar Nascimento)

Barely anyone in this space speaks English, however, they all seem to know the lyrics to every antiquated roots reggae track. DJ T (a resident female DJ from bairro de Fatima) played tracks these four albums in sequence that drew a lot of the crowd who were hanging outside back into the dance space: Jackie Edwards' "Flying Cymbal, Epic's "Another Festival", The Meditations" "Babylon Trap" and the Gladiator's "Looks is Deceiving". These tracks had the entire room bursting with energy until the policia militar came to shut everything down. Unlike the scene I had described in Rotatorio in the previous chapter, the $P M$ entered the premises relatively "peacefully" this time but they were fully armed. Their goal was not to protect the space but to intimidate and shut the event down and they made that evident. The three $P M$ that had entered the establishment went to the owner of Celso Cliff at the back of the room and they returned with the owner who went straight to DJ T to end her set.

The space and reputation of Celso Cliff is a great deal for most reggaeir@s just like Novo Quilombo, another periferia club in Liberdade, a reggaeir@ space that I have visited several times during my recent visits to São Luis. The crowd's demographic in 
these two spaces are very similar. The biggest difference is that Novo Quilombo's owner is a black man who is a member of the policia militar, and so he is better able to "protect" his establishment and clients from the violent practices of other PM Officers. Novo Quilombo, according to reggaeir@s that frequent this establishment, has never had an issue getting licensing to play music past a certain hours of the night, neither does the club get bombarded by squads of police cars outside its doors after 10:00 p.m. like Celso Cliff.

The $P M$ entrance into Celso Cliff represent just another of those routine practices where police aggressively enter reggaeir@spaces to enforce licensing laws although no one was particularly breaking any laws. Unlike Chama Maré, no one was smoking marijuana or doing any sorts of illicit recreational drugs. Clients at Celso Cliff were not even allowed to smoke cigarettes inside the establishment. And yet, the politics of arbitrary surveillance and routine invasion of reggaeir@ spaces by the $P M$ were in full force that night. Just like rotatoria reggaeir@s in this space did not appear bothered as it seemed these routine checks have customarily become the norm.

At this point of the night, I saw DJ B. and DJ N. (one of the very few popular female roots reggae DJs in the city) who were on Celso Cliff's roster walk past the eight $P M s$ who were on their walkie-talkie calling for backup ready to instill more force in case anyone resisted the shutdown. Riba, who had received a phone call from his informant officer friend, was by the stage whispering the tip into DJ T's ear, pointing to the officers at the door. At this point, DJ T, who had been simultaneously conducting the crowd and announcing the next reggae events around, exclaimed "caramba!" "Damn it!" into the microphone. The music stopped abruptly; everyone was intuitively aware of what was 
happening and they started rushing to the door. I had already made my way outside so I waited on Riba for us to head back home. He finally made it outside and said, "and now for the last of the night". I could not believe my ears but I was determined to be a selfprofessed reggaeira by surviving the night. We got into the car and drove to the biggest event of the reggaeir@ scene, Festa da Recordação.

\section{Situations II: Competition and Reggaeir@ismo}

Festa da Reçordação (FDR) occurs around the second Saturday or Sunday in August in Espaço Aberto, one of the most historically popular reggae spaces in the impoverished São Francisco neighborhood. The club was full to its maximum capacity when we arrived. The doors had to be closed since anymore attempts to cramp more people in there would have prompted the over thirty fully-armed policia militar to enter the establishment to once again shut the festivities down. Many people were turned away at the door but they refused to head back to their homes and so they lingered outside to engage in a bit of cerveja leisure.

\section{Vinyl Sets and Antiquity: Roots and Routes in the Art of Disc Jockeying}

Before the evening festivities, a DJ'ing contest is often held for contestants to play their best collection of vinyl records. There were eight competitors this year and all of them were male. There had been female competitors in the past but this year there were none. One person was disqualified because one of his records was scratched and so it skipped several times during the competition. Since the inception of the competition, the judges for the contest have been the same year after year. During the competition the judges seemed incredibly disinterested; some were having side conversations and not 
paying attention while the contestants went through their sets. Each contestant played two songs and the two finalists were chosen for the finale. The competitors were mostly members of the group of vinyl collector associations in the city. Many described this year's competition as boring in comparison to the previous year when there were twenty people competing. Most people were there for the festivities after the competition and not so much the competition itself. According to many reggaeir@s this competition marks the best time and space of the year to make new reggaeir@ friends. The event had the most mixed crowd from all neighborhoods around the city.

Riba and I arrived just in time for the finale of the competitions. The two finalists were HBR from the "Jah Man" collection group and the other was MR, a disabled private collector who was not affiliated with any vinyl collection group. I interviewed both contestants before and after their sets:

This was my very first year participating. I got involved because the group (his collector group) started investing in more albums. It's a big deal to get to the end of such a big contest here at the Espaço Aberto's FDR. I had been in the group for four years when I started collecting reggae. Ever since I came to Espaço Aberto twenty years ago, it has been a very significant part of my life as a reggaeiro that changed my life. I see what I am doing as the preservation of reggae in the city (HBR, interview with author at FDR).

I live in São Francisco and I have been participating in this contest since '94, and have already won once. I am not part of any collector's group. Being at reggae parties means a lot of good things for me, and being at peace with God, carrying on with life. I like reggae. Reggae means spiritual peace. I have issues, but when I listen to reggae, I forget my problems; I forget what I am. Being at this party means meeting people of all races, friends, Espaço Aberto, is the temple of reggae music. Today it contributes a lot and it has contributed a lot until today. I have been collecting reggae since ' 89 and as I live here I always come to Espaço Aberto. But I don't think I'm a reggaeiro. Reggaeir@ is one who like reggae and enjoys going to reggae. He is a working person. Reggaeir@ is one who is always listening to reggae (MR, interview with author at FDR) 
After the competition, MR won and was awarded R\$1000. I, on the other hand did not "win" at my attempts to live a full night of reggaeir@ismo. I nagged Riba for us to conclude our night of exploring reggaeir@ spaces. I had experienced enough for the night to get a better understanding of the embodiment of the reggaeir@ identity and creations, experiencing it in their performative spaces. Throughout my research I became increasingly interested in how the Afro-Maranhese identity is organized through and within the performative space of reggaeir@musical practices such that extends beyond the performative space itself. In the last section of this ethnographic chapter, I document and explore "voices" of reggaeir@s in "situations" that examines these processes.

\section{Situation III:}

\section{Espaço Aberto and San Francisco: Power, Politics and the Reggaeir@ Movement}

Following my short excursion to the Festas da recordação (FDR), one of my interviewees, HBR, who was one of the competitors at the FDR and a member of Agrucorem (An association of Vinyl collectors) invited me to the birthplace of the oldest reggaeir@event space,Espaço Aberto in neighborhood of São Francisco. I attended the group's meeting to observe how the reggaeir@ performance-scape impacts other aspects of the reggaeir@identity beyond the dance space. I felt the need to document the words of reggaeir@s themselves to give the reader a good idea as to how the Afro-Maranhese identity is produced within and through the reggaeir@ space. Using Rosaldo's (1989)'s

mapping system of documenting the voices of postcolonial people, I present experiences of reggaeir@s as they recount it as a way of adding a poly-vocal support to my auto- 
performance ethnography. My goal is to show the reader through these voices that the reggaeir@identity extends beyond the performance and the spaces they occur in. Reggaeir@ismo is an intricate part of the Afro-Maranhese identity through which commerce, politics and governmentality are organized.

At the heights of the $80 \mathrm{~s}$ and $90 \mathrm{~s}$, Espaço Aberto was known as the renowned club space where politicians and artists of the reggaeir@ scene interacted. The infamous late DJ, Antonio Jose hailed and played in this space. The owner of Espaço Aberto is also the owner of one the largest radiola company, "Estrela do Som". In several interviews with reggaeir@s at this Agrucorem meeting they recount how any association with Estrela do Som and Espaço Aberto helped several reggaeir@s climb the political ladder using the reggaeir@ space as a platform. Others recount how reggaeir@ismo impact politics, commerce and community organizing:

\section{Reggae is our identity: Reggaeir@Sou Eu/I am Reggaeir@}

There is a lot of racial discrimination against reggae in this city. For one there is a lot of violence in these places. Especially with the younger folks who do not seem to understand how hard we have fought for our identity and continue to fight for our identity. When I say violence, I mean violence from the young people and also from the $P M$. I have always been a reggaeiro but I can say I have a lot of prejudice against young people who are taking over our culture with robozinho, you know the electronic nonsense they play these days and call it reggae. Reggae is roots and agarradinho not "hippie hoppie" thing these kids are doing. We have to fight against the police intimidating and killing us and the robozinho kids choose to fight against each other. Reggae is our identity. I wish these young ones understood that but they don't. 
Most people think that reggae is just about dancing but it is not. It is more than that. Take for example, "Espaço Aberto", it managed to get the city to pay attention to our neighborhood when famous politicians such as Sarney Filho, Haroldo Savoia realized that they need us to win political campaigns. The reggaeir@ life is about the way we dress, the joy in the lyrics of our songs and the awareness that we are black people. We are not of the RastafarI religion but the Rastafari culture impacts us through the reggae music and we unconsciously follow it. The mottos of roots reggae music is about peace, equality and the denouncing of bad politics and this is what reggae has done for our neighborhood aside from the dancing. It has provided the space for our people to meet and discuss our things. Black things that these white people running the city don't know nothing about.

\section{Reggae in Politics: "We help radiola win elections and they abandon us"}

I know many people in this community will tell you the $P M$ brutalizes our people [meaning black people]. Of which, many do, I am a member of the $P M$ but I don't because I am from this community. So I don't blame them to think we are all bad. I can say one thing for a fact; reggae has served our black communities well, it is just the struggle for our government to accept it for what it is. For me, I see reggae as the cry of the lower classes, it creates an identity for us, which is why the reggae clubs in the suburbs are crowded now. They are trying to mimic what we have. It is even becoming popular with the rich people now although they won't admit it. But of course they will open clubs of their own and will not let us in. So, we must maintain what is ours by protecting it. I believe it is a serious movement that is united and doing a lot for this community. Unfortunately radiola owners take advantage of the people in poor communities. They recognize the importance of our vote and the loyalty that we give them to win elections. They use reggae events to popularize their agendas, promise our people a lot of things, win elections and then we never hear from them again. But the fight continues!

According to an old newspaper article in Jornal Pequeno, Mr. F. of Itamaraty

Radiola Company employed the support of the reggaeir@ community to become the first state congressman in the early 2000s. For the first time, reggaeir@s managed to elect a state representative into the elite space to get their voices heard in government. During 
the elections, reggaeir@s from various communities collaborated with various events and festivities to ensure his election. Some of the goals for the community's support was to ensure that police brutality in the reggaeir@space ends and the culture of reggaeir@s is given the same recognition as other cultural forms in the city. However, it appears that many reggaeir@s have lost hope in electing radiola owners to represent them as recounted by these interviewees:

We have elected the first reggaeir@ state congressman and the federal deputy with our votes. We are powerful and the elite knows it. Reggaeir@ culture is not just about entertainment and now the government is beginning to see the effects of that. I just wish everyone doesn't become corrupt after we elect them, you know. We organize with the members of the "movimento negro". Both radiola owners that we elected into government has inserted reggaeir@ culture and our communities into the world of politics. These radiola owners were all elected with the discourse that they represented the reggaeir@ masses. But once they are elected they did practically nothing for the masses, especially concerning the ending of social and economic discrimination against the reggae movement. And until today these two figures are the most powerful "controllers" of the business and politics in this city. You see, we are powerful. All I can say is that these people use our platforms, they use and abuse it knowing our power.

These days we use our power to help our own communities. We are very careful not to elect people into government for their own pockets. Vinyl collectors, club owners, the black movement, musicians, DJs, buyers and sellers in the reggaeir@ culture all create the face of black people in Maranhão. Sister, these days, you cannot even go to the rural areas and countryside and find a black person in Maranhão who will say reggae is not our identity. It may have just started as dancing thing because Ave Maria! Our people love dancing and enjoying themselves. But we are also building our communities using our entertainment platforms in reggae. Reggae is us and we are reggae and reggae is Maranhão, reggae is our identity. Reggae is Afro-Maranhese.

I conclude this chapter with the note on the title of this dissertation, which I

believe encapsulates this theme of this chapter well: "Reggaeir@ Sou Eu" "I am 
reggaeir@" or "Reggaeir@ is me". I chose this title as a play on words on a popular Maranhese folkloric song entitled, "Maranhão Sou Eu". I chose this title to exude my experience in Maranhão and the exploration of spaces that reggaeir@s embody as part of their blackness. I also chose this title to signify my embodiment of auto-performance ethnography - to show that it is a collaborative effort between the researcher and the population studied. The aim of this chapter is intended to show the joint lens of my experience and voices of reggaeir@s in portraying Afro-Maranhese identity that is reggaeir@ismo and beyond the space of reggaeir@ismo. 


\section{VII: Conclusion, Where the Work Starts}

Prior to starting this dissertating project, I did not plan to dive deeply into the historiographies of São Luis's musicology plainly for the fact that it was not my focus and I do not consider myself a historian by any means. However, I am an interdisciplinary scholar, and so as far as this project is concerned, questions of facts and date of particular occurrences were of great importance. Accordingly, during the field work of this research, I often found myself asking particular questions pertaining to the presence of reggae music in a space that is deemed as "out of place. For instance, who was the first collector of reggae music in São Luis? What radio station played the first track of reggae in Maranhão? What were the most popular songs of the 1960s and 1970s during the inception of agarradinho dancing to roots reggae? When did São Luis and Jamaica forge a transnational musical connection? Why is agarradinho dancing to reggae music especially embodied in style, and what records initiated these articulations?

This part of the research may have resulted due to the fact that I am attempting in part to construct the historiography of a musical culture that requires knowing and acknowledging issues and facts of what occurred in this instance, scenarios that are long gone and cannot be replicated. Consequently, the difficulty in doing such research is narrowing down large amounts of information into concise and digestible portions.

Various people from different perspectives provide varying and often times conflicting accounts of historical events. Many narratives are based on urban legends that are recounted as a matter of fact. As such, I present the source of information that 
targeted my research questions, especially those pertaining to historiography and dates are based on my intuitive categorization as I went along with my research. I addressed for example, the aforementioned questions with different sources of information, this is not limited to interviews with reggaeir@s, record collectors, DJs, fellow academics, biographies, archives, newspaper reports, music scene publications and advertisements etc. I use phrases such as "it appears", "it seems as if", "and it is reported as" to leave room for constructive criticism and argumentation that may perceive other findings that expand on my own. However, where my research questions demand discussions of concrete responses that are no longer historically discoverable, I factor such questions into larger thematic conversations theoretically. I have highlighted them in this dissertation rather than conceal them in vague historical information. Thus, questions such as "what influenced reggae's sustenance at its inception in São Luis?" "When do reggaeir@s perceive police brutality as a threat?", and "how and when is reggae culture negotiated in São Luis?" I connect these questions to even larger themes of agency, discourse and significance of black musical forms in Brazil.

In the end, my ultimate goals is to not get derailed by the difficulties of adding to the pre-existing academic conversations and knowledge production, but to emphasize individual and specific narratives that matter and contribute to different perspectives about the research concerning Brazilian music and dance culture in general. Most significantly, my goal with this work is to emphasize that research, unlike the academic discursive notions of "invention of tradition", culture is seen as inventions and thus culture cannot be invented (Handler 1991); Ulin 1995). At the same time tradition cannot be ontologically or epistemologically differentiated from an authentic one, so I concede 
that all accounts in this research are by their very nature discursive. Therefore, in line with my analytical framework, all of the accounts used in this work can only be produced by particular people who have lived these narratives from a perspective that they can call their own. I also do not mean to imply by any means that all accounts can be viewed as equal or valid. Moreover, I do not aim to lay claim to an objectivizing authority over the data and accounts I have presented in this work (Clyford and Marcus 1986; Fabian 1983).

In this research, I acknowledge that because I had to crosscheck and compare historiographies and genealogical accounts, the data and accounts I have presented are systematic and comparative. I also acknowledge that the production of knowledge is discursive and I do not as a researcher expect to be locked into any particular discourse perpetually. In researching a Brazilian music and dance form, I do take into consideration that the pitfalls of some of the discursive lens that I have incorporated into my work. This includes categories such as "working class" "Brazilian”, "tradition”, “modernity”, "agency" etc. In processing the basis of my analysis of this work, I am cognizant of the fact and need to question my own categories as well as that of my population of study in their invocation of these categories. Although, this may lead to a routine exercise of poststructuralist deconstruction, which calls for dissecting and uncovering every minute agenda behind categories that are also subjected to further deconstruction, I propose that in practice, the goal of research in social science fields such as mine aim to challenge categories within locales. My analysis are therefore not finite or universal, instead it is to be taken as critique made in relation to the context of São Luis, which is also in flux, partly as a consequence of the my critiques itself (Giddens 1990). 
In Brazil, there has been many very few academic accounts of roots reggae music and dance culture outside of the state Maranhão. The ones produced have been mainly graduate level masters and doctoral theses. Carlos Benedito da Silva, a cultural anthropologist has been the main source of academic production of knowledge about reggaeir@ culture, as part of the general cultural practices of Afro-Maranhese culture. Outside of academia, film production, bloggers and artists form Europe and Maranhão have given several accounts of roots reggae music and dance culture in São Luis. These accounts have served as the factual basis for my account as well as the themes for this dissertation. A substantial objective of this research has been to analyze the purpose and role that the reggaeir@performative spaces serve and that academic perspectives and non-academic work about such purposes are not always different. However this depends on how extensive and academic these accounts have been.

My work is meant to fill these gaps. It is Glissant's suggestion that all diasporic cultures are the product of a rhizome. The many roots of reggaeir@ identity as I have shown in the chapters above are a product of intertwined localized hybridities that stand in challenge of Brazil's hybridized statist discourse of racial democracy. In the reggaeir@performative spaces Afro-ludovicenses seek socio-cultural autonomy in defining their citizenship and ways of belonging in São Luis do Maranhão. Their way of belonging inscribed in reggaeir@ismo is defined by the validity of Caribbean-rooted musical and dance performance forms that have served as a unifying point of reference for their communities (Dantas 2009). Affirmative action policies as racial crisis management tools do not translate in practice as aggressive policing against black bodies and black spaces continue to be a lived reality of racial inequality for many Afro- 
Brazilians. I qualify these assertions by organizing this dissertation as follows: In the first chapter, I discuss the literature that informs this project in order familiarize the reader with the scholarship of hybridity in Postcolonial Studies I focus on the discursive inclusion and exclusion of Afro-Brazilian in the space of citizenship under the institution of affirmative action policies. I argue that affirmative action policies mainly manage the realities of racial disparities by attempting to obscure the contradictions of the discourse of racial democracy while it simultaneously maintains the racial hierarchical order imposed by the hybridity discourse.

I also suggest that affirmative action attempts to reactively manage the contradictions by obscuring the crisis of violence against black bodies with social reforms that thwart the advances of equal rights for Afro-Brazilians. I use these arguments to suggest that the studies of these contradictions are best accessed in the localized processes of hybridity. Using the performative spaces of reggaeir@s as a lens I examine the discourse of belonging and citizenship in Brazil. In the second chapter, I trace the historiographies of the city of São Luis and the various socioeconomic, sociopolitical and sociocultural factors that have influenced roots reggae music culture in the city. I show the genealogy of the performance-scape of roots reggae in São Luis that were developed from the intricate mixtures of Caribbean sounds, rhythms and sensibilities. I use this chapter to demonstrate how the interconnections between the access to AM Radio, the onset of the Brazilian Black Social Movement and the development of the lover's rocksteady and roots style introduced by the Jamaican artist, Jimmy Cliff in Brazil informed the reggaeir@ performance-scape. Finally, I show the importance of the contribution of the sound system industry and subversive dance spaces around São Luis 
produced black cultural spaces and informal music industry that extended beyond reggaeir@ culture.

In the third chapter, I focus on statist discursive formation, its documentary practices and their instrument effects of disciplining, surveillance, violence and punishment. I show how racial democracy and affirmative action and hybridity are instrumentalities of an oppressive state and are used to justify and normalize racial violence. I connect this argument generally to the practices of surveillance and violence through ethnographic and archival data that I have collected in the places that agarradinho occurs, and the forms of self-representation and meaning that is produced within the performance-scapes as seen in the succeeding chapter.

In the fourth chapter, I focus on an analysis of roots reggae music and dance as counter discourse and its relationship to the performative space of Afro-Maranheses and how it is distinguished from Afro-Brasilidade Space and its influence on ABS. I suggest that agarradinho is a form of counter-discourse that challenges the statist discourse of racial democracy, affirmative action and hybridity. I suggest that the entire performance space organized around music and dance, including the cultural space organized around reggaeir@ismo is counter discursive. I show how it is manifested beyond the actual performance that allows Afro-Maranhese identity to be organized through and within the performative space of roots reggae music and dance.

Finally, in the fifth chapter, I build on my analysis of the "rhizomatic" experiences of reggaeir@s from the previous chapter and how they have been shaped by the historiographies of São Luis do Maranhão through an ethnographic study of reggaeir@ismo, and how embodied music and dance performance shape spaces around 
the city. Here, I provide localized performative specificities and situated understandings of the processes that shape reggaeir@ performance identity, musical and dance practices. Specifically, I examine reggae and dance scene in clubs, open enclosed radiola spaces, and concerts and offer first person voice mapping of interviews to create polyphonic support for my auto-performance ethnography.

Overrall, I dedicate this work to all reggaeir@s, to whom I am eternally indebted. It is also my goal to contribute to the body of work that analyzes cultural politics. In analyzing the cultural politics of representation of reggaeir@s in São Luis, I contribute to the knowledge of popular music culture in Cultural Studies as I engage the statist discourses of racial democracy and affirmative action. Finally, in addressing the lived realities of police violence in reggaeir@ spaces specifically, I contribute to the body of work that addresses the nuances in studying musical practices in Postcolonial Studies and Latin American Studies. 


\section{Bibliography}

Andrews, George Reid. "Afro-Latin America: Five Questions." Latin American and Caribbean Ethnic Studies 4.2 (2009): 191-210.

Assunção, Matthias Röhrig. "Popular culture and regional society in nineteenth-century Maranhão, Brazil." Bulletin of Latin American Research (1995): 265-286.

Anzaldúa, Gloria. Borderlands: la frontera. Vol. 3. San Francisco: Aunt Lute, 1987. Bakhtin, Mikhail Mikhaŭlovich. The dialogic imagination: Four essays. Vol. 1. University of texas Press, 2010.

Benhabib, Seyla. The claims of culture.

Benítez-Rojo, Antonio. "Creolization and Nation Building in the Hispanic Caribbean." Matatu 27/28 (2003): 17.: Equality and diversity in the global era. P rinceton University Press, 2002.

Benoist, Jean. "La créolisation: locale ou mondiale?." de la créolisation culturelle (sous la direction de L'Etang, Gerry), Archipélies 3-4 (2012): 19-30.

Bernabé, Jean, et al. "In praise of Creoleness." Callaloo (1990): 886-909.

Bernard, H. Russell. Research Methods in Anthropology. 4th ed. New York: AltaMira 
Press, 2006

Berardinelli, John D., and Paul R. Goulart. "Handbag holder." U.S. Patent No. 3,860,210. 14 Jan. 1975.

Bhabha, Homi K. The Location of Culture. routledge, 2012.

Bilby, Robert E. "Contributions of road surface sediment to a western Washington stream." Forest Science 31.4 (1985): 827-838.

Bonniol, Jean-Luc. "Au prisme de la créolisation. Tentative d'épuisement d'un concept." L'Homme. Revue française d'anthropologie 207-208 (2013): 237-288.

Brah, Avtar. "Cartographies of Diaspora, london and New York." (1996).

Canclini, Néstor García. Imagined globalization. Duke University Press, 2014.

Cassiolato, José E., and Marcelo Matos. "The sounds of Brazil: the popular music and the music industry: José E. Cassiolato, Marcelo Matos and Helena Lastres." Creative Industries and Developing Countries. Routledge, 2007. 154-181.

Cavallaro, James, and Anne Manuel. Police brutality in urban Brazil. Human Rights Watch, 1997.

Chang, Kevin O'Brien, and Wayne Chen. Reggae routes: The story of Jamaican music. Temple University Press, 1998.

Chevigny, Paul. "REVIEW OF NEW YORK CITY POLICE CORRUPTION INVESTIGATION COMMISSIONS, 1894-1994 (GABRIEL J. CHIN ED., 1997)." Western New England Law Review 21.1 (1999): 233.

Clark, Katerina, and Michael Holquist. Mikhail bakhtin. Harvard University Press, 1984.

Collier, Gordon, and Ulrich Fleischmann, eds. A Pepper-pot of Cultures: Aspects of Creolization in the Caribbean. Vol. 27. Rodopi, 2003.

Conquergood, Dwight. "Ethnography, rhetoric, and performance." Quarterly journal of Speech 78.1 (1992): 80-97.

. "Rethinking ethnography: Towards a critical cultural politics." Communications monographs 58.2 (1991): 179-194.

Cooper, Carolyn. Sound Clash: Jamaican Dancehall Culture at Large. First ed. Houndsmills Basingstoke Hampshire: Palgrave Mcmilian, 2004.

Corbetta, Piergiorgio. Social Research: Theory, Methods and Techniques. Thousand 
Oaks, CA: Sage, 2003.

Corbin, J., and A. Strauss. Basics of Qualitative Research: Techniques and Procedures for Developing Grounded Theory. Thousand Oaks, CA: Sage, 2008.

Crang, Mike, and Ian Cook. Doing Ethnographies. Thousand Oaks, CA: Sage Publications, 2007.

Crook, Larry. Brazilian Music: Northeastern Traditions and the Heartbeat of a Modern Nation.

Santa Barbara, California: ABC-CLIO, 2005.

---. Focus: Music of Northeast Brazil. London, UK: Routledge, 2009.

Costa, Dione Ribeiro. "Ancestralidade em A dolorosa raiz do micondó, de Conceição Lima." (2016).

Coundouriotis, Eleni. "The Dignity of the Unfittest: Victims' Stories in South Africa." Hum. Rts. Q. 28 (2006): 842.

Da Costa, Alexandre Emboaba. "Anti Racism in Movement: Afro Brazilian Afoxé and Contemporary Black Brazilian Struggles for Equality." Journal of Historical Sociology 23.3 (2010): 372-397.

Dantas, Mariana LR. "Chica da Silva: A Brazilian Slave of the Eighteenth Century." Journal of Social History 44.3 (2011): 950-952.

Daniel, Yvonne. Caribbean and Atlantic Diaspora Dance: Igniting Citizenship. Champaign, Illinois: University of Illinois Press, 2011.

Dantas, Beatric Góis. Nagô Grandma and White Papa: Candomblé and the Creation of Afro-Brazilian Identity. University of North Carolina Press, 2009.

Davis, Martha Ellen. "' Bi-musicality" in the cultural configurations of the Caribbean." Black Music Research Journal (1994): 145-160.

Denzin, Norman K. Performance ethnography: Critical Pedagogy and the Politics of Culture. Sage, 2003.

Dunn, Kevin M. "A paradigm of transnationalism for migration studies." New Zealand Population Review 31.2 (2005): 15-31. 
Emerson, Robert, Rachel Fretz, and Linda Shaw. Writing Ethnographic Fieldnotes. Chicago: University Chicago Press, 1995.

Erasmus, Z. ed. Coloured By History, Shaped by Place: New Perspectives on Coloured Identities in Cape Town, Cape Town: Kwela (2001).

Farias, Bernardo. "O Merengue na formação da música popular urbana de Belém do Pará: Reflexão sobre as conexões Amazônia-Caribe." Revista Brasileira do Caribe (2011).

Ferretti, Sergio. "Contribuição cultural do negro na sociedade maranhense." (2008).

. Ed. Tambor de Crioula: Ritual e Espectaculo. São Luis: ComisSão Maranhese de Folclore, 2002.

Freire, Karla Cristina Ferro. Que Reggae e esse que Jamaicanizo a "Atenas Brasileira? Master's thesis, Universade Federal do Maranhão 2010.

Freyre, Gilberto. The Mansions and the Shanties: The Making of Modern Brazil. Translated and edited by Harried de Onis. Berkeley: University of California Press, 1986 [1933].

Frith, Simon. "The Making of the British Recording Industry, 1920-64." Impacts and Influences: Essays on Media Power in the Twentieth Century. Eds. James Curran, Anthony Smith, and Pauline Wingate. London: Methuen, 1987

Foucault, Michel, and Paul Rabinow. "Ethics, Subjectivity and Truth: Essential Works of Foucault 1954-1984 (Vol. 1)." Trans. C. Porter (New York: The New Press, 1997) (1997).

Geertz, Clifford. The Interpretation of Cultures. New York: Basic Books, 1973.

Gikandi, S. "Africa, Diaspora, and The Discourse of Modernity," Research in African Literatures, 27 (4), 1-6 (1996).

Geertz, Clifford. The Interpretation of Cultures. New York: Basic Books, 1973.

Gilroy, Paul. ""Jewels Brought from Bondage": Black Music and the Politics of Authenticity in the Black Atlantic: Modernity and Double-Consciousness, Chapter 3." Reissue Edition ed. Cambridge, Massachusetts: Harvard University Press, 1993.

---. The Black Atlantic: Modernity and Double Consciousness. Cambridge: Harvard University Press, 1993. 
---. "Sounds Authentic: Black Music, Ethnicity, and the Challenge of a "Changing" Same." Black Music Research Journal 11.2 (1991): 111-136.

----.There ain't no black in the Union Jack. Routledge, 2013.

---. The Black Atlantic: Modernity and Double Consciousness. London: Verso, 1993.

---. The Black Atlantic: Modernity and Double Consciousness. Cambridge: Harvard University Press, 1993.

---. "Sounds Authentic: Black Music, Ethnicity, and the Challenge of a "Changing" Same." Black Music Research Journal 11.2 (1991): 111-136.

Glaser, B., and A. Strauss. The Discovery of Grounded Theory: Strategies for Qualitative Research. New York: Aldine, 1967.

Glissant, Edouard. "Beyond Babel." World Literature Today 63.4 (1989): 561-564.

Guest, Greg, Arwen Bunce, and Laura Johnson. "How Many Interviews are enough?: An Experiment with Data Saturation and Variability." Field Methods 18 (2006): 5982.

. Caribbean Discourse. Charlottesville VA: University of Virginia 1989.

Guerrero, Jose. "Vida, Passion y Muerte del Bolero." In El Bolero en la Cultura Caribena y su Proyeccion Universal; Memorias del III Congreso Internacional Musica, Identidad y Cultura en el Caribe, edited by Dario Tejeda and Rafael Emilio Yunen, 245-47. Santiago de los Caballeros; Instituto de Estudios caribenos, 2010.

Gonzalez, Rafaela Rohsbacker, and Heloísa de Araújo Duarte Valente. "Voz-ruído na canção popular brasileira: a expressividade das vozes femininas do samba-canção da década de 1950." (2017).

Guilbault, Jocelyne. "Audible entanglements: Nation and diasporas in Trinidad's calypso music scene." Small Axe 9.1 (2005): 40-63.

Hale, Charles. "Rethinking indigenous politics in the era of the "indio permitido"." NACLA Report on the Americas 38.2 (2004): 16-21.

. "Cultural Politics of Identity in Latin America." Annual Review of Anthropology 26 (1997): 567-590.

Hanchard, Michael. Racial Politics in Contemporary Brazil. Durham, North Carolina: Duke University Press Books, 1999. 
Henriques, Julian. "Situating Sound: The Space and Time of the Dancehall Session." Thamyris/Intersecting: Place, Sex and Race, Sonic Interventions. Eds. Sylvia Mieszkowski and Marijke de Valck, Joy Smith. Amsterdam, Netherlands: Rodopi, 2008. 287-309.

---. "Sonic Diaspora, Vibrations, and Rhytm: Thinking through the Sounding of the Jamaican Dancehall Session." African and Black Diaspora: An International Journal 1.2 (2008): 215-236.

---. "The Vibrations of Affect and their Propagation on a Night-Out on Kingston's Dancehall Scene." Body \& Society 16.1 (2010): 57-89.

Hallewell, Laurence. O Livro no Brasil: sua Historia. São Paulo: Editora da Universidade de São Paulo, 1985.

Hall, H. Glenn. "Parental analysis of introgressive hybridization between African and European honeybees using nuclear DNA RFLPs." Genetics 125.3 (1990): 611-621. Hardt, Michael, and Antonio Negri. Empire. Harvard University Press, 2000.

Helgesson, Stefan. "Black atlantics." Same and Other: Negotiating African Identity in Cultural Production, Stockholm: Nordiska Africa Institutet (2001): 23-36.

Hesse, Barnor. "Diasporicity: Black Britain's post-colonial formations." Un/settled multiculturalisms: Diasporas, entanglements, transruptions (2000): 96-120. Hernandez, Deborah Pacini. Oye como va!: Hybridity and identity in latino popular music. Temple University Press, 2010.

Hintzen, Percy C., and Sandy Macintyre. Race and Creole ethnicity in the Caribbean. 2002.

Instituto Brasileiro Geografia e Estatica (IBGE). "Censo Demografico 2010; Resultados Preliminares do Universo." http:www.sidra.ibge.gov.br/cd/cd2010rpu.asp?o=6\&i=P (accessed June 2016).

Johnson, E. Patrick. "Black performance studies: Genealogies, politics, futures." The Sage handbook of performance studies. SAGE Publications Inc., 2006. 446-463. . Appropriating blackness: Performance and the politics of authenticity. Duke University Press, 2003.

King, Stephen A., Barry T. Bays, and P. Renée Foster. Reggae, Rastafari, and the rhetoric of social control. Univ. Press of Mississippi, 2002. 
Kraniauskas, John. "Néstor García canclini's culturas híbridas: Estrategias para entrar y salir de la modernidad (Mexico 1990). Hybridism and reterritorialization." Travesia 1.2 (1992): 143-151.

Lamen, Darien. "Claiming Caribbeanness in the Brazilian Amazon: lambada, critical cosmopolitanism, and the creation of an alternative Amazon." Latin American Music Review 34.2 (2013): 131-161.

Lefebvre, Henri, Eleonore Kofman, and Elizabeth Lebas. Writings on cities. Vol. 63. Oxford: Blackwell, 1996.

Levine, Robert M. The history of Brazil. Greenwood Publishing Group, 1999.

\section{Lipsitz, G. Dangerous Crossroads: Popular Music, Postmodernism and the Poetics of} Place. London: Sage, 10-38. 1994.

Machado, Eduardo Paes, and Ceci Vilar Noronha. "A polícia dos pobres: violência policial em classes populares urbanas." Sociologias 4.7 (2002): 188-221.

Madison, D. Soyini, and Judith Hamera. "Performance studies at the intersections." The Sage handbook of performance studies (2006): xi-xxv.

Madison, D. Soyini. Critical ethnography: Method, ethics, and performance. Sage publications, 2011.

Mahmood, Saba. "Feminist theory, embodiment, and the docile agent: Some reflections on the Egyptian Islamic revival." Cultural anthropology 16.2 (2001): 202-236.

Manuel, Peter. "Gender politics in Caribbean popular music: Consumer perspectives and academic interpretation." Popular Music \& Society 22.2 (1998): 11-29.

May, Stephen. "Critical multiculturalism and education." The Routledge international companion to multicultural education. Routledge, 2009. 53-68.

Medeiros, Marcelo, et al. "Inequality, poverty, and the Brazilian social protection system." Brazil Emerging. Routledge, 2014. 46-63. 
Meethan, Kevin. "Mobile cultures? Hybridity, tourism and cultural change." Journal of Tourism and Cultural Change 1.1 (2003): 11-28.

Miereles, Mario M. Historia do Maranhão. 2 nded. São Luis: Fundacao Cultural do Maranhão. 1980.

Monson, Ingrid. The African diaspora: a musical perspective. Routledge, 2018.

Morse, Janice. "Designing Funded Qualitative Research." Handbook for Qualitative Research. Thousand Oaks, CA: Sage, 1994.

Mosguera, G. “Global Islands," in O. Enwezor et. al. (eds.) Creolite and Creolization Documento 11 Platform 3. Ostfildern-Ruit: Hatje Cantz 87-92, (2005).

Nuttall, Sarah, and Cheryl-Ann Michael, eds. Senses of culture: South African Culture Studies. Oxford University Press, USA, 2000.

Oboler, Suzanne, and Anani Dzidzienyo. Neither Enemies Nor Friends: Latinos, Blacks, Afro-Latinos. Springer, 2005.

Papastergiadis, Nikos, and Peter Lyssiotis. "The home in modernity." Transition 56 (1997): 60 .

Pedrosa, Luis Antonio Camara. "A Reforma Agraria no Nordeste o Caso do Maranhão." Associacao Brasileira de Direito Agrario, http://www.abda.com.com/texto/LuisACPedrosa.pdf (accessed March 2016).

Peres, Maria Fernanda Tourinho, et al. "Homicídios, desenvolvimento socioeconômico e violência policial no Município de São Paulo, Brasil." Revista Panamericana de Salud Publica 23 (2008): 268-276.

Phelan, P. "Feminism, epistemology and education." The RoutledgeFalmer reader in philosophy of education. Pendlebury, Shirley. (2005): 50-61.

Prefeitura Municipal de São Luis, Legislacao Urbanistica Basica de São Luis. São Luis: Secretaria Municipal de Terras, Habitacoes e Urbanizacao (SEMTHURB), 1997.

Puri, Shalini. The Caribbean Postcolonial: Social Equality, Post-Nationalism, and Cultural Hybridity. New York: Palgrave Macmillan, 2004. 
Rahier, Jean Muteba. "From Panacea for Harmonious Race Relations to Ideological Tool for Oppression and National Identity Imagination: Reflections from the Andes on mestizaje through Time and Space." Blackness in the Andes. Palgrave Macmillan, New York, 2014. 65-88.

Ryan, Gery, and H. Russell Bernard. "Techniques to Identify Themes." Field Methods 15.1 (2003): 85-109.

Safa, Helen I. "Racial and gender inequality in Latin America: Afro-descendent women respond." Feminist Africa 7: Diaspora Voices (2006).

Sheriff, Robin E. "The theft of Carnaval: national spectacle and racial politics in Rio de Janeiro." Cultural Anthropology 14.1 (1999): 3-28.

Sheriff, Robin E. Dreaming Equality: Color, Race, and Racism in Urban Brazil. New Brunswick, New Jersey: Rutgers University Press, 2001.

Sampaio, Aidil and Risalva Vasconcelos Rochas. Tendencias das Migracoes no Nordeste, 1940-1980. Recife; Ministerio do Interior, SUDENE, 1989.

Schechner, Richard. "TDR Comment: Theatre Alive in the New Millenium." TDR: The Drama Review 44.1 (2000): 5-6.

Schomburg-Scherff, Sylvia M. "The power of images: New approaches to the anthropological study of images." Anthropos (2000): 189-199.

Shohat, Ella. "Notes on the" Post-Colonial"." Social text 31/32 (1992): 99-113.

Silva, Carlos Benedito Rodrigues da. Da Terra Das Primaveras à Ilha do Amor: Reggae, Lazer e Identidade Cultural. São Luis do Maranhão, Brazil: EDUFMA, 1995.

---. Ritmos Da Identidade: Mestiçagens e Sincretismos Na Cultura do Maranhão. São Luis do Maranhão, Brazil: Seir/fapema/edufma, 2007.

Strauss, H. "Living the Pain of Creolization: Shifting Contexts of Subject Formation" in K. Sello Duiker's Thirteen Cents and Lueen Conning's A Coloured Place," in N. Distiller and M. Steyn, Under Construction: "Race" and Identify in South Africa Today. Sandton, Johannesburg; Heinemann. 26-37.

Sousa, Jhonatan Uelson Pereira. Alguns desafios ao planejamento e desenvolvimento do Maranhão, Brasil: contexto histórico, obstáculos e estratégias de superação.Planejamento e Políticas Públicas 37 (2011).

Taylor, Charles. "The politics of recognition. Multiculturalism: Examining the politics of recognition." Multiculturalism and the politics of recognition (1994): 25-75.

Telles, Edward E. Race in another America: The Significance of Skin Color in Brazil. Princeton, New Jersey: Princeton University Press, 2006. 
Thomas, Deborah A. Modern Blackness: Nationalism, Globalization, and the Politics of Culture in Jamaica. Durham: Duke University Press, 2004.

Trovao , Jose R. "Transformacoes Sociais e Economicas no Espaco Rual da Ilha do Maranhão. PhD. Diss. Universidad Estadual Paulist_-Rio Claro, 1994.

Turner, Michael and Otavio Rodrigues. "The Maranhão Version: Reggae Time Warp in Brazil” The Beat 26, no. 1 (2007).

Vale de Almeida, Miguel. An Earth-Colored Sea: Race, Culture and the Politics of Identity in the Post-Colonial Portuguese-Speaking World. Oxford, UK: Berghahn Books, 2004.

Vergès, Françoise. "Indian-Oceanic creolizations: Processes and practices of creolization on Réunion Island." Creolization. Routledge, 2016. 141-160.

Veloso, Caetano. Tropical Truth: A Story of Music and Revolution in Brazil. Translated by Isabel de Sena. Edited by Barbara Einzig. New York: Alfred A. Knopf, 2002.

Wade, Peter. "Blackness, Music and National Identity: Three Moment in Colombian History." Popular Music 17.1 (1998): 1-19.

---. Music, Race and Nation: Musica Tropical in Colombia. Chicago: University of Chicago, 2000.

Walcott, Rinaldo. "Pedagogy and trauma: The middle passage, slavery, and the problem of creolization." Between hope and despair: Pedagogy and the remembrance of historical trauma (2000): 135-151.

Wright, Michelle M. Becoming black: Creating identity in the African diaspora. Duke University Press, 2004.

Yawson, Gee A. "Educação e Acões Afirmativas: Redefining Multicultural Legalisms, Justiciability of Rights, and the [In]clusion of African-descendant peoples in Higher Education in Brazil", in Human Rights, Race and Resistance in Africa and the African Diaspora, edited by Cacee Hoyer and Toyin Falola. 2017.

------. "Que dança é essa?: Reflections of Gendered Power Relations and Sociocultural Expressions of Sexuality in Agarrado Dancing to Roots Reggae in São Luis do Maranhão, Brazil", Pp. 117-132 in Ethnicities, Nationalities, and Cross-Cultural Representations in Africa and the Diaspora, edited by Gloria Chuku. Carolina Academic Press. 2015

Young, Robert JC. "Foucault on race and colonialism." New Formations (1995): 57-57. . Colonial desire: Hybridity in theory, culture and race. Routledge, 2005. 
VITA

GLORIA ANGEBELLE YAWSON

2005

B.S. Biological Psychology B.S.

Applied French Linguistics

Pennsylvania State University

University Park, Pennsylvania

2008

M.S. Justice Law and Society

American University

Washington D.C.

2013

J.D. Law

St. Thomas University School of Law

Miami, Florida

2015

L.LM. Intercultural Human Rights Law

St. Thomas University School of Law

Miami, Florida

2010-2014

Teaching Assistant

Florida International University

Miami, Florida

2014-2017

Adjunct Professor

Broward College

Davie, Florida

2017-2018

Teaching Assistant

2015-2016 Boren Fellowship. Institute of International Education.

2014-2015 Foreign Language and Area Studies Fellowship. Florida International University.

2011 Tinker Fellowship. Florida International University.

2010-2014 Teaching Assistantship. Florida International University.

2003-2005 Certificate for Superior Academic Performance. The Pennsylvania State University.

2003-2005 Liberal Arts Scholarship. The Pennsylvania State University.

2002-2005 Button-Waller Scholarship. The Pennsylvania State University. 
Florida International University

Miami, Florida

2010-2019

Doctoral Candidate

Florida International University

Miami, Florida

\section{PUBLICATIONS AND PRESENTATIONS}

2017. Yawson, Gee A. “Educação e Acões Afirmativas: Redefining Multicultural Legalisms, Justiciability of Rights, and the [In]clusion of African-descendant peoples in Higher Education in Brazil", in Human Rights, Race and Resistance in Africa and the African Diaspora, edited by Cacee Hoyer and Toyin Falola.

2015. Yawson, Gee A. "Que dança é essa?: Reflections of Gendered Power Relations and Sociocultural Expressions of Sexuality in Agarrado Dancing to Roots Reggae in São Luis do Maranhão, Brazil”, Pp. 117-132 in Ethnicities, Nationalities, and Cross-Cultural Representations in Africa and the Diaspora, edited by Gloria Chuku. Carolina Academic Press.

2015. "The Ins and Outs of Graduate Funding, Fellowships and Travel Grants." Department of Study Abroad, Florida International University. September 29th, 2015.

2013. "Educação e Ações Afirmativas: Redefining Multicultural Legalism and the [in]clusion of African-descendant peoples in Higher Education in Brazil." Africa Conference, Austin, Texas.

2013. "Embodied Movements in the Circum-Caribbean Diaspora: Negotiating the Cultural Politics of Dance in the Construction of National Peoplehood." Toyin Falola Annual International Conference on Africa and the African Diaspora, Ibadan, Nigeria.

2012. "Que dança é essa?: Reflections of Gendered Power Relations and Sociocultural Expressions of Sexuality in Agarrado Dancing to Roots Reggae in São Luis do Maranhão, Brazil.” Toyin Falola Annual International Conference on Africa and the African Diaspora, Lagos, Nigeria.

2011. "Roots Reggae Culture in São Luis do Maranhão, Brazil". Tinker Research Award Recipient Public Forum, Department of Latin America and Caribbean Center, Florida International University. November 3rd, 2011.

2011. "Life After Graduation: Applying to Graduate and Law Schools". The Eta Kappa Sigma Alumni Chapter of Sigma Gamma Rho Sorority, Inc., Florida International University Black Alumni Association and FIU Black Student Association, Public Forum and Lecture. November 2nd, 2011. 